
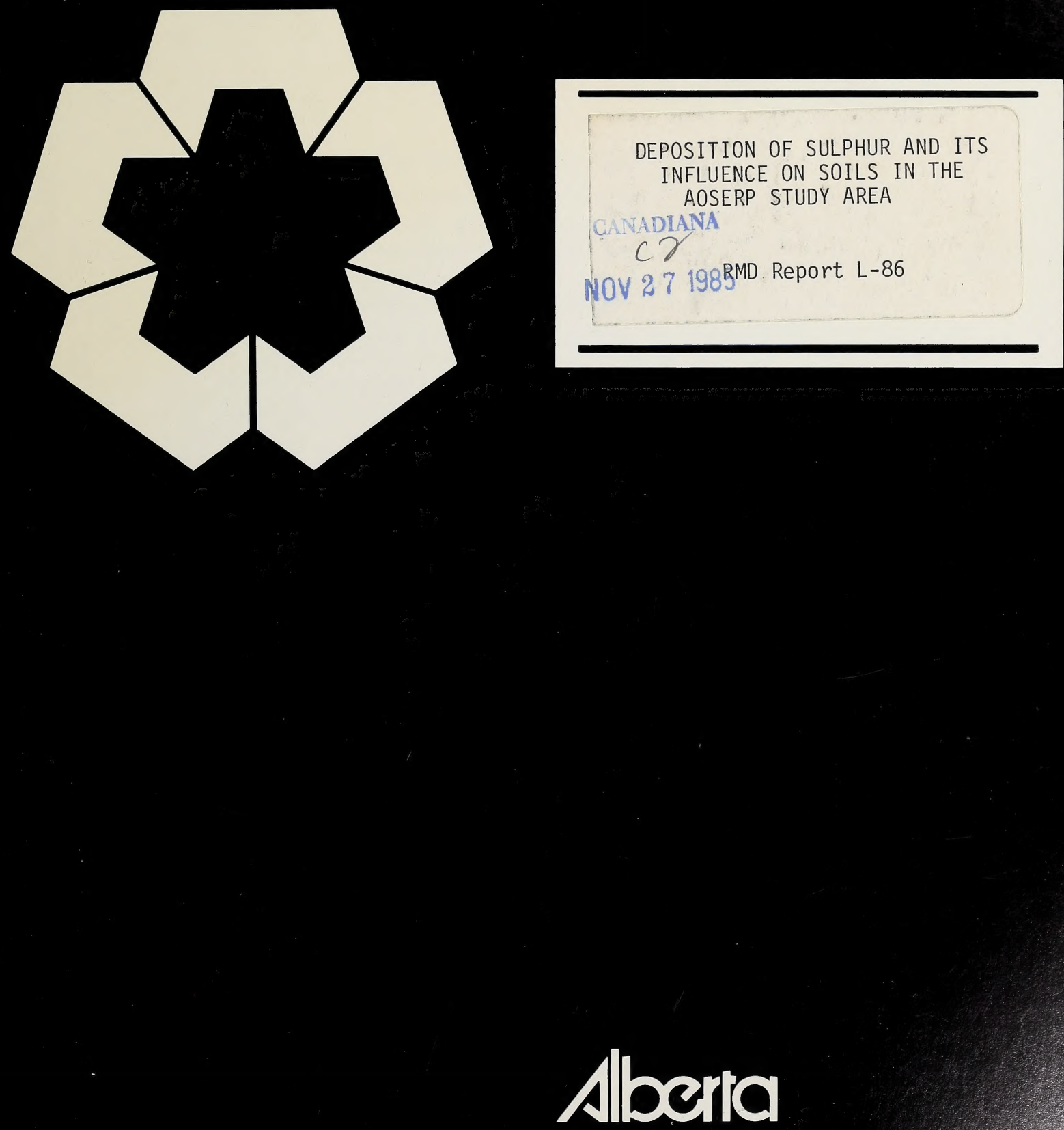

ENVIRONMENT

Environmental Protection Services

Research Management Division 


\section{RESEARCH MANAGEMENT DIVISION EMBLEM}

The Emblem represents the interdisciplinary and holistic nature of the Division's environmental research programs. Each of the five sections of the symbol represent comprehensive programs on air, water, land, humans and their constant interaction. The sections converge to form a cohesive chain, characteristic of an effective research organization. This cohesive bonding makes the sections blossom into the environment in the form of a flower - an Albertan wild rose. 


\section{DEPOSITION OF SULPHUR AND ITS INFLUENCE ON SOILS IN THE AOSERP STUDY AREA}

\section{RESEARCH MANAGEMENT DIVISION \\ ALBERTA ENVIRONMENT}


Digitized by the Internet Archive in 2016

https://archive.org/details/depositionofsulp00nybo 
For further information on reports published by the Research Management Division, contact:

Research Management Division

Publications Office

14th Floor, Standard Life Centre

10405 Jasper Avenue

Edmonton, Alberta

T5J 3N4

(403) $427-3946$

This report may be cited as:

Nyborg, M., R.W. Parker, S. Takyi, and P. Yeung. 1985. Deposition of sulphur and its influence on soils in the AOSERP study area. Prep. for the Research Management Division, Alberta Environment by Department of Soil Science, University of Alberta. AOSERP Report L-86. 153 pp. 
This report is made available as a public service. The Alberta Department of Environment neither approves nor disagrees with the conclusions expressed herein, which are the responsibility of the authors. 


\title{
DEPOSITION OF SULPHUR AND ITS INFLUENCE \\ ON SOILS IN THE AOSERP STUDY AREA
}

\author{
by \\ M. NYBORG \\ R.W. PARKER \\ S. TAKYI \\ P. YEUNG \\ Department of Soil Science \\ University of Alberta
}

\author{
for \\ RESEARCH MANAGEMENT DIVISION \\ Alberta Environment
}

LS 4.2

AOSERP Report L-86

1985 
TABLE OF CONTENTS

Page

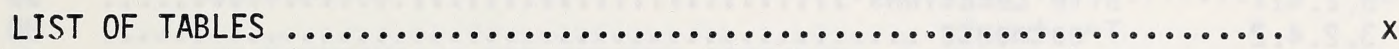

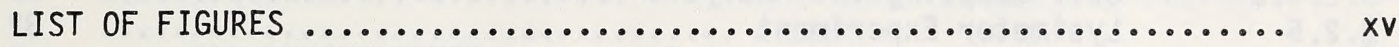

ABSTRACT $\ldots \ldots \ldots \ldots \ldots \ldots \ldots \ldots \ldots \ldots \ldots \ldots \ldots \ldots \ldots \ldots \ldots \ldots \ldots \ldots \ldots \ldots \ldots \ldots \ldots \ldots$

ACKNOWLEDGEMENTS $\ldots \ldots \ldots \ldots \ldots \ldots \ldots \ldots \ldots \ldots \ldots \ldots \ldots \ldots \ldots \ldots \ldots \ldots \ldots \ldots \ldots \ldots \ldots \ldots \ldots$

1. INTRODUCTION $\ldots \ldots \ldots \ldots \ldots \ldots \ldots \ldots \ldots \ldots \ldots \ldots \ldots \ldots \ldots \ldots \ldots \ldots$

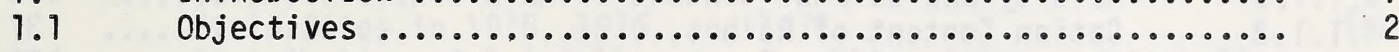

2. RESUME OF CURRENT STATE OF KNOWLEDGE $\ldots \ldots \ldots \ldots \ldots \ldots \ldots \ldots \ldots$

3. EXPERIMENTAL PROCEDURES $\ldots \ldots \ldots \ldots \ldots \ldots \ldots \ldots \ldots \ldots \ldots \ldots \ldots \ldots \ldots \ldots \ldots \ldots \ldots \ldots \ldots \ldots$

3.1 Description of the Study Area ........................... 6

3.1 .1

3.1 .2

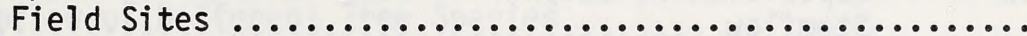

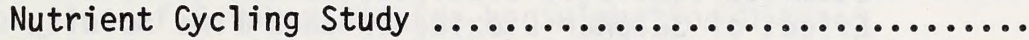

3.1 .3

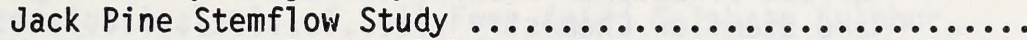

Movement of Applied Sulphate Sulphur in Forest Soils ...

3.1 .4 .1

3.1 .4 .2

Mildred Lake Research Facility Site .................

Ruth Lake Site .................................

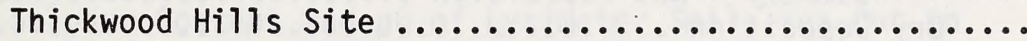

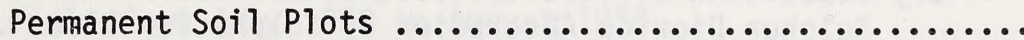

3.1 .5

3.2

3.2 .1

3.2 .1 .1

3.2 .1 .2

3.2.1.3

3.2 .1 .4

3.2 .2

3.2.2.1

3.2 .2 .2

3.2 .2 .3

3.2.2. 4

3.2 .3

3.2.3.1

3.2 .3 .2

3.2 .4

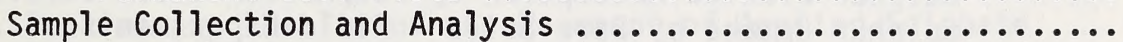

Wet Deposition .................................. 18

Precipitation Measurements ....................... 18

Precipitation Sampling ........................... 21

Nutrient Cycling Study ......................... 21

Jack Pine Stemflow Study ........................ 22

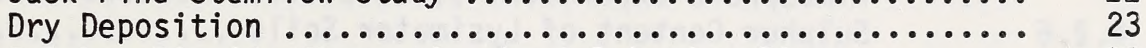

Sulphur Dioxide Absorption by Sulphation Discs ........ 23

Sulphur Uptake by Bare Soils - Field Experiments ...... 23

Sulphur Uptake by Lichen Covered Soils

- Field Experiment ............................ 25

Sulphur Uptake by Lichen Covered Soils - Controlled

Atmosphere Experiment ........................... 25

Movement of Applied Sulphate Sulphur in Forest Soils ... 27

Treatments ................................. 27

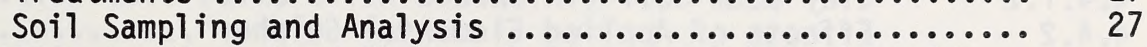

Effects of Applied Elemental Sulphur, Sulphuric Acid, and Lime on Soil Acidity ......................... 30 


\section{TABLE OF CONTENTS (CONTINUED)}

3.2 .4 .1

3.2 .4 .2

3. 2.4 .3

3.2 .5

4.

4.1

4.1 .1

4.1 .1 .1

4.1 .1 .2

4.1 .1 .3

4.1 .2

4.1 .3

4.1.3.1

4.1.3.2

4.1 .4

4.1 .5

4.1. 6

4.2

4.2.1

4.2 .2

4. 2.3

4.2 .4

4. 2.5

4. 2.6

4.3

4. 3.1

4. 3.2

4.4

4. 4.1

4.4 .1 .1

4.4 .1 .2

4. 4.2

4.4.2.1

4.4 .2 .2

4.4 .3

4. 4.3 .1

4.4.3.2

4.5

4.6
Site Locations

Treatments

Soil Sampling and Analysis

Lysimeter Experiment
Page

30

30

31

32

34

34

34

34

34

37

39

39

Nutrient Cycling Study $\ldots \ldots \ldots \ldots \ldots \ldots \ldots \ldots$
Deposition of Sulphur in Aspen Throughfal 1 and

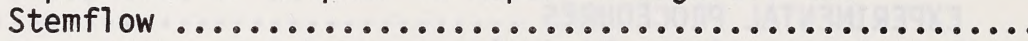

47

49

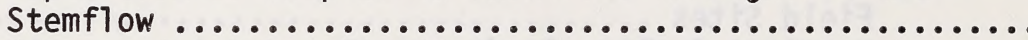

Effect of Sulphur Dioxide on Jack Pine Acidity

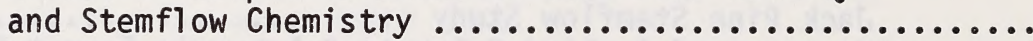

Impact of Sulphur Dioxide on Bark Leachate Acidity

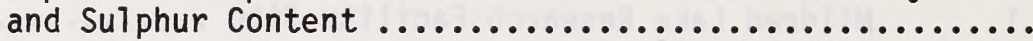

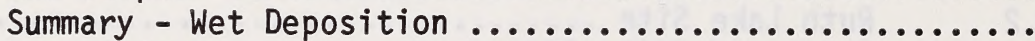

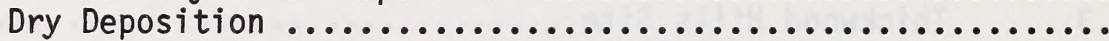

Sulphur Dioxide Absorption by Sulphation Discs .........

Sulphur Uptake by Bare Soils - Field Experiments ........

Sulphur Uptake by Bare Soils - Controlled Atmosphere

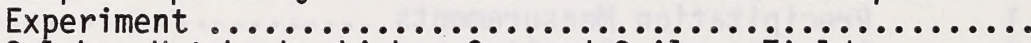

Sulphur Uptake by Lichen Covered Soils - Field

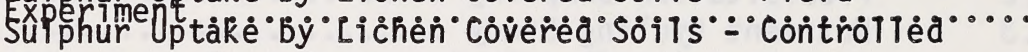

Atmosphere Experiment

Sulphur Content of Lysimeter Soils

Movement of Applied Sulphur in Forest Soils

Sandy Soil (Mildred Lake Research Facility Site) ........

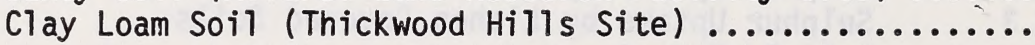

Effects of Applied Elemental Sulphur, Sulphuric Acid and

Lime on Soil Acidity ..............................

Effects of Applied Sulphuric Acid ...................

Sandy Soil (Mildred Lake Research Facility Site) .......

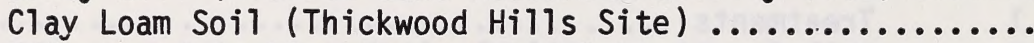

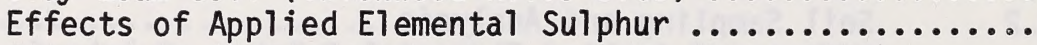

Sandy Soil (Mildred Lake Research Facility Site) .......

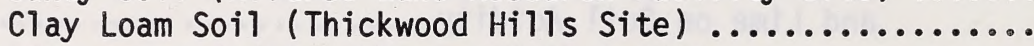

Effects of Applied Lime on Soil Acidity ...............

Sandy Soil (Mildred Lake Research Facility Site) ........

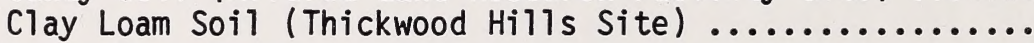
Lysimeter Experiment

Permanent Soil Plots

\section{1}

56

58

60

60

60

67

67

70

72

75

75

77

79

79

79

79

82

82

82

83

83

83

83

84 
TABLE OF CONTENTS (CONCLUDED)

5. CONCLUSIONS $\ldots \ldots \ldots \ldots \ldots \ldots \ldots \ldots \ldots \ldots \ldots \ldots \ldots \ldots \ldots \ldots,{ }^{2}$

6. RECOMMENDATIONS FOR FURTHER RESEARCH $\ldots \ldots \ldots \ldots \ldots \ldots \ldots \ldots . . \ldots 2$

7. REFERENCES CITED $\ldots \ldots \ldots \ldots \ldots \ldots \ldots \ldots \ldots \ldots \ldots \ldots \ldots \ldots \ldots \ldots \ldots \ldots$

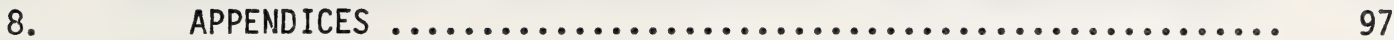

8.1 The Total Precipitation for Each Month Recorded at Each of

the Field Sites over the Summers of 1976 and 1977 ..........

8.2 Sulphate Sulphur Deposition in Rain Measured at Each of the

Field Sites in 1975, 1976, and $1977 \ldots \ldots \ldots \ldots \ldots \ldots \ldots . . . . . .100$

8.3 Distribution of Rainfall under Trembling Aspen and Jack Pine

Stands Used in the Nutrient Cycling Study, $1976 \ldots . . . . . .$.

8.4 Acidity and Nutrient Content of Incident Rain in Jack Pine and

Trembling Aspen, Throughfall and Stemflow ............... 109

8.5 Acidity and Sulphur Concentration in Throughfall and

Stemflow of Different Tree Species .................... 115

8.6 Absorption of Sulphur Dioxide by Sulphation Discs ......... 119

8.7 Regression Analysis of Soil Free Acid, Sulphate Sulphur, and Total Sulphur Concentration Versus Distance from a

Sulphur Dioxide Emission Source and Estimated Average

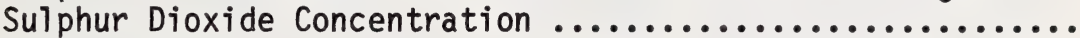

8.8 The Sulphur Content and pH of Lysimeter Soils Set Out in the Field from July 1976 to August 1978 ................ 124

8.9 Preliminary Results of the Movement of Applied Sulphate Sulphur in Forest Soils Experiment .................... 131

$8.10 \quad$ Analysis of Lysimeter Leachates ....................... 134

8.11 Analysis of Permanent Plot Soils ...................... 139

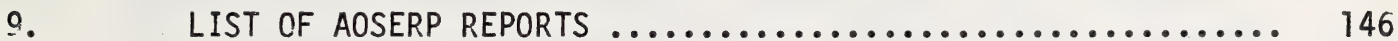




\section{LIST OF TABLES}

Page

1. Distances $(\mathrm{km})$ and Direction of the Research Sites from the

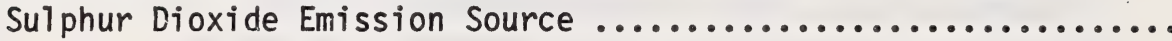

2. Description of the Plots Used for the Nutrient Cycling

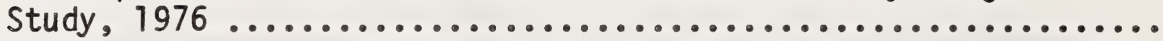

3. Description of the Four Jack Pine Stemflow Study Sites ....... 16

4. Soil Texture and Bulk Density of Soils from Sites of the Applied Sulphur Movement Experiment

5. Analyses of Lichen Covered Soils Used in Field Experiment on Sulphur Uptake by Undisturbed Soils

6. Analysis of Lichen Covered Soils Used in Controlled Atmosphere Experiment on Sulphur Uptake by Undisturbed Soils

7. Ehtegopf Elemental Sulphur, Sulphuric Acid, and Lime Applied to

8. Sulphur Concentrations (ppm) and pH of Rain Sampled Monthly

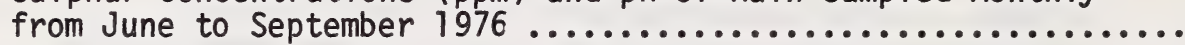

9. Sulphur Concentrations (ppm) and pH of Rain Sampled Monthly from May to September 1977

10. Concentration (ppm) of Cations in Rain Sampled Monthly from May to September 1977

11. Chemical Determinations on Accumulated Snow Sampled on March 17 and 18, 1976

12. Precipitation (mm) at the Control Site and the Exposed Site of Nutrient Cycling Study, Summer of 1976

13. Mean Nutrient Concentration (ppm) and Mean pH of Incident Rain in the Summer of 1976 at Plots of Nutrient Cycling Study .......

14. Mean Total Sulphation for the Control Site and the Exposed Site

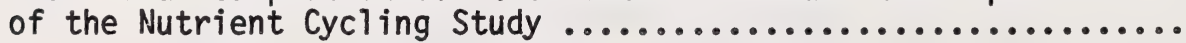

15. Mean Nutrient Concentrations (ppm) and Mean pH of Throughfall and Stemflow in Summer 1976

16. Mean Nutrient Concentrations and pH of Rain; and of Trembling Aspen and Jack Pine Throughfall and Stemflow 


\section{LIST OF TABLES (CONTINUED)}

Page

17. Deposition of Sulphate Sulphur in Trembling Aspen Throughfall and Stemflow at Control Site and at Exposed Site, Summer 1976 ..

18. Deposition of Sulphate Sulphur in Jack Pine Throughfall and Stemflow at Control Site and at Exposed Site, Summer 1976

19. Acidity and Sulphate Sulphur Content of Jack Pine Stemflow Sampled at Four Sites During June and July 1977 .............

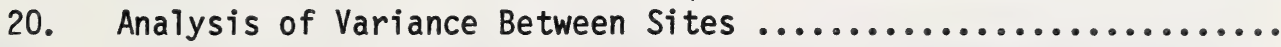

21. Relationship of Acidity and Sulphate Sulphur Content of Jack Pine Stemflow Sampled at Four Sites During June and July 1977 .....

22. $\mathrm{pH}$ and $\mathrm{SO}_{4}{ }^{2-}-\mathrm{S}$ Content of Bark Washings Exposed to $\mathrm{SO}_{2}$ in Controlled Environment Chamber for Seven Days .............

23. $\mathrm{pH}$ Values of the Top $1 \mathrm{~cm}$ of Soils Exposed Under Rain Shelters from June to September 1975

24. $\mathrm{pH}$ Values and Sulphur Content $(\mathrm{kg} / \mathrm{ha})$ of the 0 . EB Soil and the TY.M Soil Set Out Under Rain Shelters from June to September 1976

25. Effect of $\mathrm{SO}_{2}$ Exposure, Under Controlled Conditions, on Soil pH Values and Total Sulphur Concentration ...............

26. Sulphur Dioxide Uptake by Intact Lichen Covered Soil Samples Set Out Under Rain Shelters from May to October 1977 ..........

27. $\mathrm{pH}$ Values and Sulphur Content of a Lichen Covered Sandy Soil Exposed to $0.1 \mathrm{ppm}$ Sulphur Dioxide for Seven Days Under

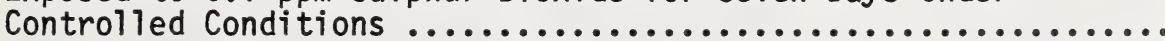

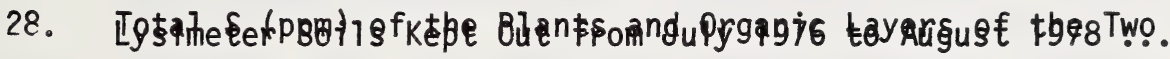

29. Sulphate Sulphur and Total S Content of Plants and Soils in Lysimeters Kept Out from July 1976 to August 1978

30. Soluble Sulphate, Total S, and Extractable Potassium Content of Soil One Year After Application of Potassium Sulphate

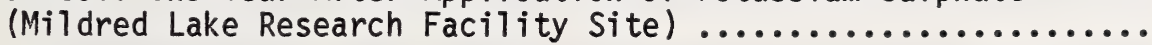

31. Soluble Sulphate, Total S, and Extractable Potassium Content of Soil One year After Application of Potassium Sulphate (Thickwood Hills Site) 


\section{LIST OF TABLES (CONTINUED)}

32. $\mathrm{pH}$ Values and $\mathrm{SO}_{42-}-\mathrm{S}$ Content of Soil Four Months After

the Application of Sulphuric Acid, Elemental Sulphur, and Lime

Treatments (Mildred Lake Research Facility Site) ..............

33. $\mathrm{pH}$ Values and $\mathrm{SO}_{4}{ }^{2-}-\mathrm{S}$ Content of Soil Four Months After the Application of Sulphuric Acid, Elemental Sulphur, and Lime Treatments (Thickwood Hills Site) ..........................

34. Relative Amounts of Sulphate Sulphur Deposited in Rain and Leached from Lysimeters from June to September 1977 ..........

35. Relative Amounts of Calcium Deposited by Rain and Leached from

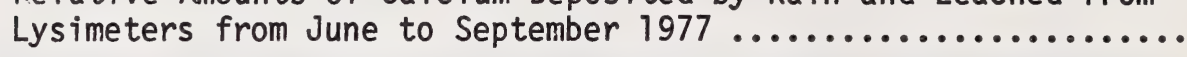

36. Total Precipitation (mm) at Field Sites for the Months of June to September 1976

37. Total Precipitation ( $\mathrm{mm})$ at the Sites for the Months of May

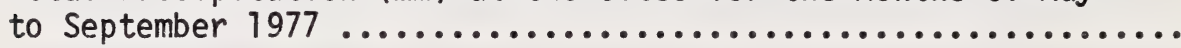

38. Average $\mathrm{pH}$ and Sulphate Sulphur Concentration in Rain and Amount of Sulphate Sulphur Deposited in Rain, Summer 1975

39. Sulphate Sulphur Deposited in Rain from July to Mid-September 1976

40. Sulphate Sulphur Deposited in Rain from June to September 1977 . 103

41. Net Rainfal1, Throughfal1, Stemflow, and Interception Under

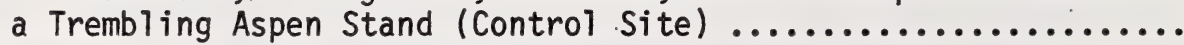

42. Net Rainfall, Throughfall, Stemflow, and Interception Under

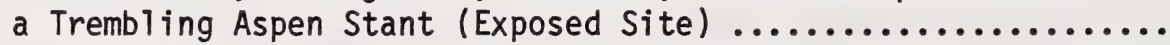

43. Net Rainfal1, Throughfall, Stemflow, and Interception Under

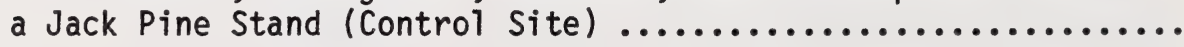

44. Net Rainfall, Throughfall, Stemflow, and Interception Under

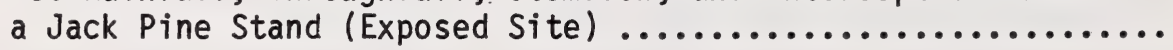

45. Cation and Sulphate Sulphur Flux for Trembling Aspen and Jack Pine at Control and Exposed Sites, 1976

46. Acidity and Nutrient Content of Incident Rain and Trembling Aspen Throughfall and Stemflow at the Control Site, 1976

47. Acidity and Nutrient Content of Incident Rain and Trembling Aspen Throughfall and Stemflow at the Exposed Site, 1976 


\section{xii}

\section{LIST OF TABLES (CONTINUED)}

48. Acidity and Nutrient Content of Incident Rain and Jack Pine

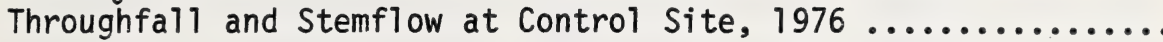

49. Acidity and Nutrient Content of Incident Rain and Jack Pine Throughfall and Stemflow at Exposed Site, 1976 .............. 114

50. Average $\mathrm{pH}$ and Sulphate Sulphur Concentration in Throughfall and Stemflow, of Different Tree Species, Collected During the

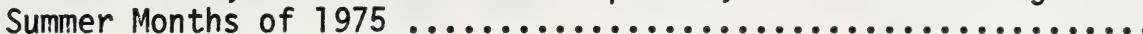

51. Average $\mathrm{pH}$ and Sulphate Sulphur Concentration in Throughfall and Stemflow of Different Tree Species, Collected from July to

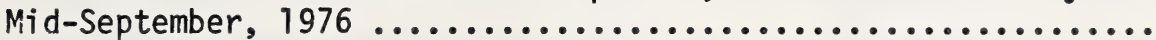

52. Amounts of Sulphate Sulphur Deposited in Throughfall and Stemflow from July to Mid-September, 1976

53. Sulphur Absorbed by Sulphation Discs Set Out Monthly from June to September, 1976

54. Sulphur Absorbed by Sulphation Discs Set Out Monthly from May to September, 1977

55. Regression Analysis of Soil Hydrogen Ion Concentration $\left(\mathrm{H}^{+}\right)$, Sulphate Sulphur Concentration $\left(\mathrm{SO}_{4}{ }^{2-}-\mathrm{S}\right)$, and Total

Sulphur Concentration (Total S) Versus Distance ( $\mathrm{km}$ ) from a Sulphur Dioxide Emission Source and Average Ambient Sulphur Dioxide Concentrations

56. Sulphate Sulphur, Total Sulphur Content, and $\mathrm{pH}$ of the Sandy O.EB Soil kept at Nine Sites from July 1976 to August 1978 .....

57. Sulphate Sulphur, Total Sulphur Content, and pH of the 0.GL Soil kept at Nine Sites from July 1976 to August 1978 .............

58. $\mathrm{pH}$ Values, $\mathrm{SO}_{4}{ }^{2-}-\mathrm{S}$ Content and Soluble Potassium Content in Soil Four Months After Application of Potassium Sulphate

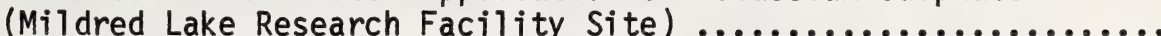

59. $\mathrm{pH}$ Values, $\mathrm{SO}_{4}{ }^{2-}-\mathrm{S}$ Content and Soluble Potassium Content in Soil Four Months After Application of Potassium Sulphate (Thickwood Hills Site)

60. Sulphate Sulphur Content and $\mathrm{pH}$ of Lysimeter Leachates Sampled Monthly from April to October, 1977 (0.GL Soil) ............... 


\section{xiv LIST OF TABLES (CONCLUDED)}

Page

61. Sulphate Sulphur Content and $\mathrm{pH}$ of Lysimeter Leachates Sampled Monthly from April to October, 1977 (Sandy O.EB Soil) ......... 136

62. Concentrations (ppm) of Cations in Lysimeter Leachates Sampled Monthly from April to September, 1977 (O.DL Soil) .............

63. Concentrations (ppm) of Cations in Lysimeter Leachates Sampled Monthly from April to September, 1977 (Sandy O.EB Soil) ....... 138

64. Sulphate Content of Top Layers of Soils in "Permanent Plot" Samples in Separate Years ............................ 140

65. Total Sulphur of Top Layers of Soils in "Permanent Plots" Sampled in Separate Years ............................. 141

66. Soil pH of Top Layers of Soils in "Permanent Plots" Sampled in Separate Years ..................................... 144 


\section{LIST OF FIGURES}

Page

1. Location of the ASOERP Study Area ...................... 7

2. Location of Sulphur Dioxide Monitoring Sites (shown by full circles and numbers), in Relation to Emission Source, and the Four Zones at Designated Distances from the Source (as shown by dashed 1 ines)

3. Layout of a Typical Plot Used in the Nutrient Cycling Study ..... 13

4. Location of Three Sites with Experimental Plots on Undisturbed Soil with Applications of Elemental Sulphur, Sulphuric Acid, and

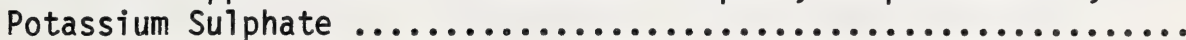

5. Field Plan of a Permanent Soil Plot. Samples were taken in 1976 and 1978

6. Controlled Atmosphere Apparatus

7. Lysimeter Design. Inside Diameter and Depth are $22 \mathrm{~cm}$ and $50 \mathrm{~cm}$, respectively

8. The Variation in Sulphate Sulphur and Acidity of Jack Pine (P. banksiana Lamb.) Stemflow with Increasing Distance from a Sūiphur Dioxide Emissions Source

9. Components of the Nutrient Cycle for a Forest Ecosystem Showing Sites of Nutrient Accumulation and Major Pathways

10. $\mathrm{pH}$ Values of $1 \mathrm{~cm}$ Top of the Sandy 0.EB Soil kept Under Rain Shelters from June to September 1976

11. Sulphur (ug/ $\mathrm{cm}^{2} / \mathrm{mo}$ ) Adsorbed by Sulphation Discs from 1976 June 01 to September 30 and in Brackets the Sulphate Sulphur (ppm) Content of the Surface of $1 \mathrm{~cm}$ of the Sandy 0.EB Soil Set Out for the Same Period

12. Sulphate Sulphur $\left(\mathrm{ug} / \mathrm{cm}^{2} / \mathrm{mo}\right)$ Adsorbed by Sulphation Discs from June to September, 1976, and in Brackets the Sulphate Sulphur (ppm) Content of the Surface of $1 \mathrm{~cm}$ of the TY.M Soil Set Out for the Same Period 


\section{ABSTRACT}

In the summers of 1975, 1976, and 1977, several field investigations were carried out to determine the amounts of sulphur deposited in rain, in rain washing off trees, and by direct absorption of $\mathrm{SO}_{2}$ by soil. The impact of this sulphur deposition on soils in the AOSERP study area was also determined in both field and laboratory experiments. Rain collected at several sites in 1977 was acidic, with some monthly rain samples having $\mathrm{pH}$ values below 5.0. The sulphur content of rain was low and there was a gradient of decreasing $\mathrm{SO}_{4}{ }^{2-}-\mathrm{S}$ deposition in rain with increasing distance from the emission source. Scarcely, any of the sulphur in rain occurred in an acidic form. When instead the rain dripped through jack pine or trembling aspen trees (throughfall and stemflow) more sulphur was deposited. The effect was greater at sites near the emission source as compared to remote sites. Total amount of sulphur in net precipitation (throughfall and stemflow) beneath jack pine and trembling aspen was greater than that in rain. For both jack pine and trembling aspen larger quantities of the cations $\mathrm{K}^{+}, \mathrm{Ca}^{2+}$, and $\mathrm{Mg}^{2+}$ were removed from the canopies at sites exposed to $\mathrm{SO}_{2}$ compared to control sites. Both bare soils and soils with intact 1 ichen cover were found to absorb $\mathrm{SO}_{2}$ directly from the air. This absorption process amounted to the most important mechanism for removal of sulphur from the atmosphere in the AOSERP study area, particularly in areas close to the emission source. The absorption of $\mathrm{SO}_{2}$ by soils was also shown to result in increased acidity of the top layer $(0$ to $1 \mathrm{~cm})$ of some soils. Field experiments showed that sulphate sulphur (applied as $\mathrm{K}_{2} \mathrm{SO}_{4}$ ) was mobile in forest soils of the AOSERP study area. Applied sulphuric acid was also found to move quite rapidly through the soils and cause an increase in the acidity of the soil as it moved downward. Ground limestone was an effective method of counteracting the effects of the applied sulphuric acid on soil acidity. 


\section{ACKNOWLEDGEMENTS}

Acknowledgement is made to Mrs. Monica Ayala-Molina for her deligent, knowledgeable work in discharging the laboratory aspects of the project. The Alberta Forest Service at Fort McMurray, the Northern Forest Research Centre of the Canadian Forestry Service at Edmonton, and the Pollution Control Division of Alberta Environment provided discussions and assistance. The Research Management Division of Alberta Environment provided excellent review of the manuscript and helped greatly in producing the final manuscript. The following people generously devoted of their time in maintaining and monitoring experimental field sites in their areas: Dr. Wendell Rice, Agriculture Canada Research Station at Beaverlodge, Alberta; Mr. John Fahl, Agriculture Canada Experimental Station at Scott, Saskatchewan; and Mr. Elling Nyborg, farmer at Canwood, Saskatchewan. 
Soils are dynamic natural bodies which constitute an important part of forest ecosystems. They are open systems to which substances may be added and removed. Soil processes and properties are therefore greatly influenced by the external chemical climate. Any direct change in the external chemical climate such as in the chemical composition of precipitation, or any indirect change such as an altered vegetative cover, will result in changes in the soil. Conversely, any changes in the soil will produce changes in vegetation and the chemical composition of drainage water. The effects of atmospheric sulphur on soils is therefore only one facet of atmosphere-plant-soil interactions.

Anthropogenic sources of atmospheric sulphur may affect forest soils via several pathways, namely:

1. In rain and snow;

2 In rainfall washing off vegetation;

3. By direct absorption of sulphur dioxide by soils; and

4. By impaction of particulate matter on soil and plant surfaces. The first two processes are referred to as "wet deposition" and the latter two as "dry deposition". In order to better understand the influence of sulphur emissions on soil properties, it is necessary to quantify these external parameters which influence soil processes.

It is for this reason the study established a network of field sites in the Alberta 0 il Sands Environmental Research Program (AOSERP) study area to monitor the chemical composition of rain, rain dripping of trees, and snow. The deposition of sulphur in particulates was determined in 1976 by Nipher gauges at several of the field sites, and the ambient sulphur dioxide concentrations were estimated in 1976 and 1977 by the use of sulphation discs set out at each field site.

The fundamental questions with which this project was concerned were:

1. How much sulphur was deposited and found its way into soil?

2. What were the resultant forms of this sulphur in soil; and

3. To what extent were soils acidified by this deposition of sulphur? 
Measurement was made of the amounts of sulphur deposited by each of the above mechanisms, and of the total deposition on soils. The change in soil soluble sulphur and total sulphur contents was measured, together with changes in soil $\mathrm{pH}$.

This report is a summary of several field investigations and laboratory experiments concerning the influence of anthropogenic sulphur on soils in the AOSERP study area.

\subsection{STUDY OBJECTIVES}

The principal objective of this project was to study the effects of anthropogenic sulphur on soils in the AOSERP study area. The major components of the objective were specifically:

1. Determine the mechanisms and rate of sulphur absorption by soils;

2. Characterize the chemical form of deposited sulphur and the proportional distribution of the various forms of sulphur in soil ;

3. Predict the chemical changes in soil caused by sulphur emissions, including the rate, direction, and magnitude of such changes;

4. Study measures to reduce any soil damage; and

5. Develop recommendations for monitoring the long-term impact of emissions on soils.

The project was designed to answer broad, important questions regarding the potential effect of sulphur emissions on soils in the AOSERP study area. The experiments were not intricate and dealt with the amounts of sulphur deposition and any resultant changes in soils. 
2. CURRENT KNOWLEDGE

In the past few decades, serious environmental problems have become apparent with increasing emissions of atmospheric sulphur dioxide. On a global scale, anthropogenic emissions of sulphur compounds are estimated to be $78 \times 10^{6}$ tonnes S/year (Erickson 1963, Kellogg et a1. 1972) with approximately an equivalent amount arising from natural emissions. Canada has five percent of the world total anthropogenic emissions (Katz 1977), while 0.23 million, tonnes per year (or approximately 0.4 percent of the world total) are emitted in Alberta (Tollefson 1972).

In Alberta, the main source of sulphur oxides is the processing of natural gas (Summers and Whelpdale 1976). This $\mathrm{SO}_{2}$ may be oxidized and hydrolyzed to $\mathrm{H}_{2} \mathrm{SO}_{4}$ which can give rise to acid rain (Brosset 1973). A trend towards increased acidity of precipitation has been found in the heavily industrialized regions of the world, namely northwestern Europe and the northeastern United States. Slightly acid precipitation has been reported in a region downwind of gas processing plants in the foothills belt of Alberta (Summers and Whelpdale 1976).

Sulphur dioxide may also give rise to acid particulates, depending on the ammonia content of the air, which may be transported long distances (Brossett 1976a). These may impinge directly on the ground surface or onto the forest vegetation and be subsequently washed off by rain (Brosset 1976b). Overrein (1972) found in lysimeter experiments that the leaching of calcium in different soil types increased considerably when the acidity of the precipitation increased. Similar increases for both calcium and magnesium were noted by Abrahamsen et a1. (1976). Tamm et al. found that treatment of soil in lysimeters with fertilizer $\left(\mathrm{NH}_{4} \mathrm{NO}_{3}\right)$ resulted in a marked increases in the degree of leaching, especially when the fertilizer was combined with dilute acid. They also found that much of the sulphur, added as sulphuric acid, was retained in the lysimeters even through the degree of leaching of calcium increased by about 25 percent. Wiklander (1975) showed that neutra1 salts in precipitation may reduce the acidification of soils by acid precipitation.

The chemical composition of rain is altered when it penetrates tree crowns. Adsorbed dry deposits are washed from surfaces and nutrients are leached from leaves (Madgwick and Ovington 1959, Nihlgard 1970, Eaton et al. 
1973, and many others). Abrahamsen et a1. (1976) found that the total deposition of sulphuric acid beneath Norway spruce (Picea abies (L.) Karst.) and scots pine (Pinus sylvestris (L.) was twice that deposited in incident rain. Baker et al. (1977) found that throughfall and stemflow was depressed in $\mathrm{pH}$ at sites close to sources of sulphur dioxide. Nyborg et a1. (1977) found increased levels of sulphur in white spruce (Picea glauca (Moench) Voss.) throughfall at exposed sites in Alberta. Stemflow and throughfall are an important influence on the physico-chemical properties of soils (Mina 1967, Gersper and Holowaychuk 1971). Field studies on forest ecosystems in southern Sweden have shown that acid canopy drip gives rise to an increase in the degre of leaching of calcium from the soil (Nihlgard 1971). In Alberta, Baker et al. (1977) found higher potassium chloride extractable acidity and aluminum, and lower exchangeable calcium and magnesium in soils exposed to sulphur dioxide compared with control site soils.

Emissions of sulphur dioxide can be directly absorbed by soils. Johansson (1959) set out bare potted soils downwind from a $\mathrm{SO}_{2}$ source for six years. The ratio of sulphur gained by the soil through direct absorption from the air to that gained through precipitation ranged from 2 to 7 , depending on the site. The $\mathrm{pH}$ of the soil was also lowered by between 0.3 and $1.4 \mathrm{pH}$ units. In Ontario, Cox (1975) set containers of three soils under canopies downwind from two $\mathrm{SO}_{2}$-emitting smelters. At sites 15 to $25 \mathrm{~km}$ from the emission source, the ph of the top $1 \mathrm{~cm}$ of a silty clay loam soil was depressed 0.2 to 0.4 units after 19 weeks of exposure. The soluble sulphate content of the soils increased by 15 to $70 \mathrm{ppm}$. In Alberta, Nyborg and Walker (1977) reported a correlation between soluble sulphate and $\mathrm{pH}$ depression for soils exposed to $\mathrm{SO}_{2}$ emissions in the field. The maximum increase in sulphate sulphur $(8.8 \mathrm{ppm})$ was not sufficient to account for the $\mathrm{pH}$ depressions.

Laboratory experiments have demonstrated that soils have a large capacity for the absorption of sulphur dioxide (Abeles et a1. 1971). The effect of suiphur dioxide on soil pH and sulphate content was related to the concentration of sulphur dioxide and the time of exposure (Yee et al. 1975). It was also related to the moisture content (Terraglio and Manganelli 1966, 
Smith et a1. 1973, Cox 1975), texture (Cox 1975) and calcium carbonate content (Cox 1975, Yee et a1. 1975) and calcium carbonate content (Cox 1975, Yee et a1. 1975) of the soil used.

Ghiorse and Alexander (1976) found that sulphur dioxide was rapidly removed from the gas phase by both sterile and non-sterile soil indicating viable micro-organisms are not directly involved in its removal from the atmosphere. Sulphur dioxide was rapidly oxidized to sulphate in the soil and soil pH was depressed slightly. In both sterile and non-sterile soil, about one quarter of the sulphur introduced as sulphur dioxide could not be recovered as sulphite or sulphate. However, if the soil was first ignited in a furnace to destroy organic matter, the recovery was complete. Apparently, this investigation indicated that sulphur dioxide can react directly with soil organic matter.

Direct absorption of sulphur dioxide by soils was found by Nyborg et al. (1977) to be the most important means of sulphur deposition in central Alberta. They estimated that as much as $50 \mathrm{~kg}$ sulphur $(\mathrm{S}) / \mathrm{ha}$ was deposited for 20 to $30 \mathrm{~km}$ downwind from large single emissions sources over the summer period. A small but measurable decrease in soil pH accompanied the increase in sulphur content of the soils, and much of the absorbed sulphur was found in non-sulphate form. 
3. EXPERIMENTAL PROCEDURES

3.1 DESCRIPTION OF THE STUDY SURVEY

The AOSERP study area (Figure 1) is part of the mixedwood section of the boreal forest region (Rowe 1972). The growing season, based on a $4^{\circ} \mathrm{C}$ index, occurs from the end of April to early October, and lasts an average of 165 days yearly. The average annual precipitation is $432 \mathrm{~mm}$ with $280 \mathrm{~mm}$ falling during the period from May to October.

At the time of this study, the only sources of sulphur emissions in the study area were located at the Great Canadian 0 il Sands processing plant (now Suncor Inc.) located at Tar Island, about $70 \mathrm{~km}$ north of the town of Fort McMurray. At this plant, there are two main sources of sulphur emissions: (1) the power house stack; and (2) the incinerator stack. The power house stack is estimated to emit an average of 120 tonnes S/day and the incinerator stack about 15 tonnes S/day. In addition, there are two flares which are intermittent sources of smaller amounts of sulphur oxides (personnel communication from M. Strosher, Pollution Control Division Alberta Environment, Edmonton).

\subsubsection{Field Sites}

A network of field sites were erected in May and June 1976. These sites occurred in four zones corresponding to increasing distances from the emission source: (1) less than $25 \mathrm{~km}$; (2) 25 to $50 \mathrm{~km}$; (3) 50 to $100 \mathrm{~km}$; and (4) over $100 \mathrm{~km}$ (remote or control sites). The position of these sites relation to the emission source is shown in Figure 2 and Table 1 . A site was also located at Canwood, Saskatchewan (502 km SE of the emissions source) which served as a distant control site. In addition, there were two more distant controls, Loon Lake, Saskatchewan (356 km SSE) and Beaverlodge, Alberta $(527 \mathrm{~km}$ WSW). In this report the terms exposed, control, and remote sites are used more to designate relative distance from the 0 il Sands plant rather than in the precise meaning of the terms with respect to deposition of sulphur emissions.

The sites, excepting Hangingstone River (Site No. 15) and Canwood (Loon Lake and Beaverlodge) consisted of a $3.7 \mathrm{~m} \times 3.7 \mathrm{~m}$ enclosure surrounded 


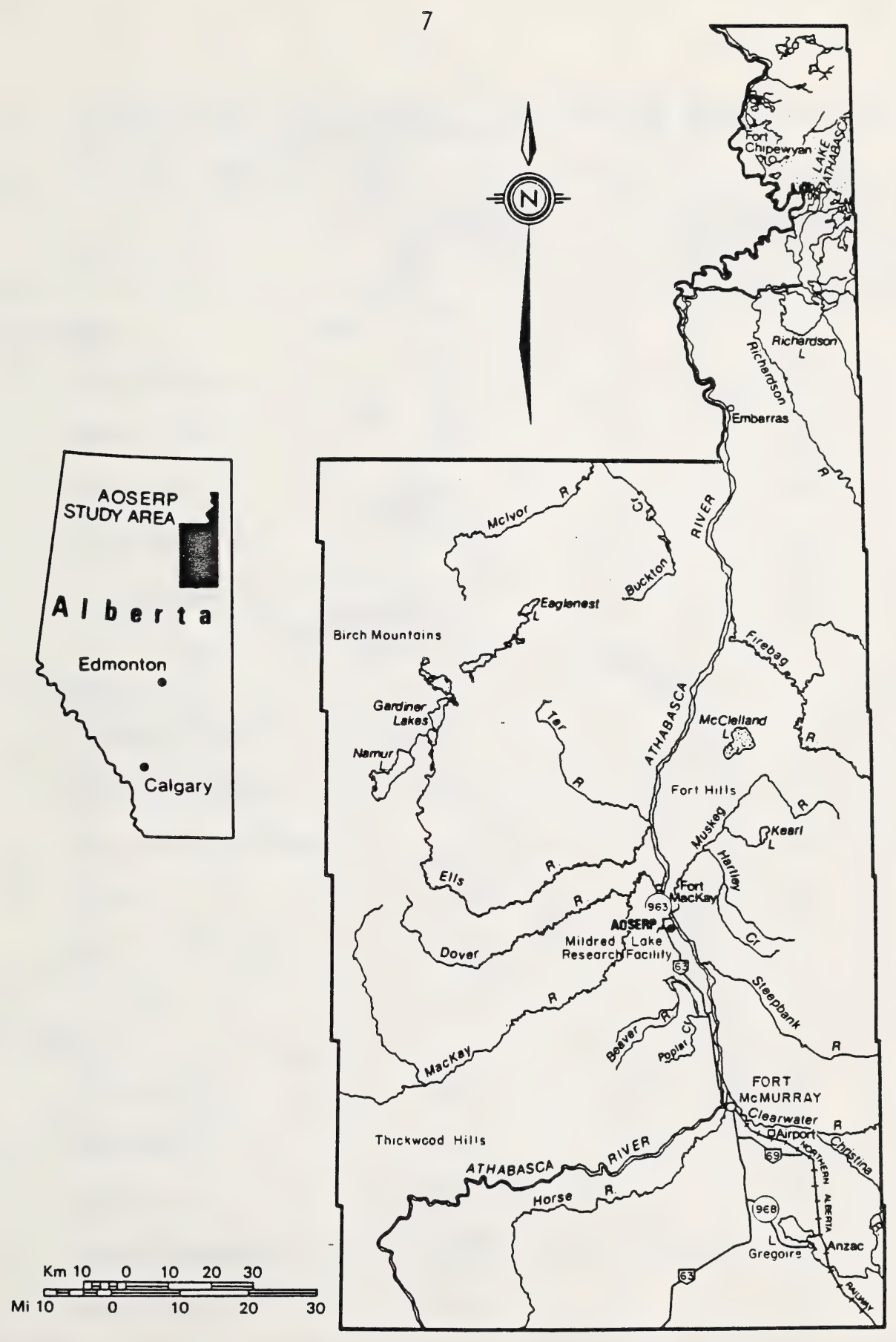

Figure 1. Location of the AOSERP Study Area. 


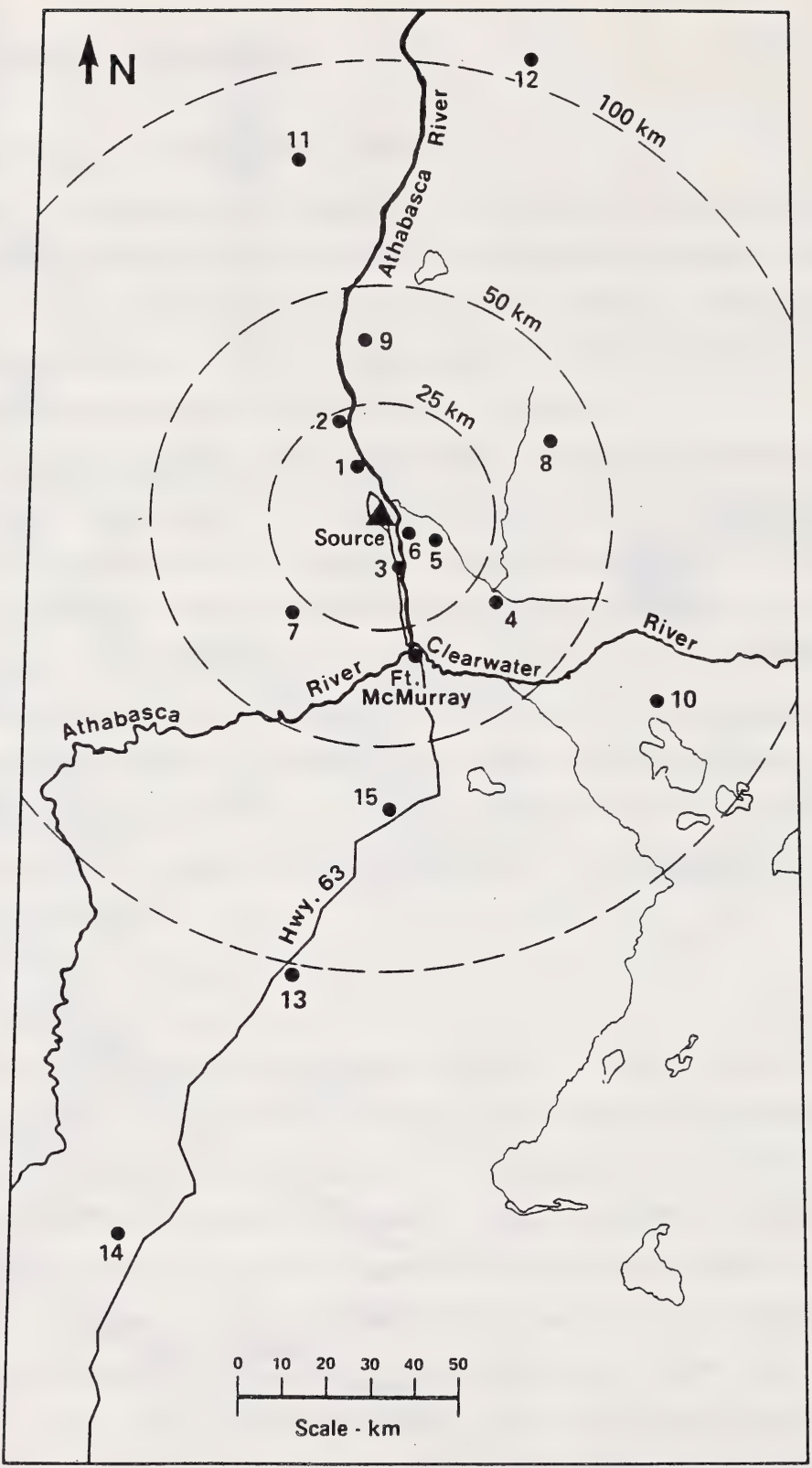

Figure 2. Location of sulphur dioxide monitoring sites (shown by full circles and numbers), in relation to emission source $(\Delta)$, and the four zones at designated distances from the source (as shown by dashed lines). 
Table 1. Distances $(\mathrm{km})$ and Direction of the Research Sites from the Sulphur Dioxide Emission Source.

Site

No.

Site
Direction

from Source
Distance $(\mathrm{km})$

from Emission Source

\section{Northerly Sites}

$\begin{array}{rllr}1 & \text { Mildred Lake } & \text { NW } & 11 \\ 2 & \text { MacKay River } & \text { NW } & 21 \\ 9 & \text { Bitumount } & \text { N } & 39 \\ 11 & \text { Birch Mountain } & \text { NNW } & 79 \\ 12 & \text { Richardson } & \text { NNE } & 102\end{array}$

Southerly Sites

\begin{tabular}{rllr}
3 & Supertest Hili & S & 7 \\
7 & Thickwood Hills & SW & 31 \\
15 & Hangingstone River & S & 67 \\
13 & Algar & SSW & 101 \\
14 & May & SW & 173 \\
& & & \\
Easterly & Sites & & 4 \\
\hline 6 & Steepbank 2 & ESE & 17 \\
5 & Steepbank 1 & ESE & 32 \\
4 & Steepbank A & SE & 38 \\
8 & Muskeg Mountain & ENE & 75 \\
10 & Gordon Lake & SE & \\
\hline
\end{tabular}


by a $1.8 \mathrm{~m}$ high 1 ink chain fence equipped with a door. Within this enclosure was a $1.8 \mathrm{~m} \times 1.2 \mathrm{~m}$ rain shelter raised $0.9 \mathrm{~m}$ above ground level.

In 1976 and 1977, each field site was equipped with a Taylor 11 inch "clear-vu" rain gauge (Sybon Corporation, N.C.). It was positioned $40 \mathrm{~cm}$ above the ground surface.

During the summer of 1976 and 1977, a rain sample collection gauge was also set up at each site. They consisted of $5 \mathrm{~L}$ polyethylene bottles fitted with polyethylene funnels of $21 \mathrm{~cm}$ inside diameter. This provided rain water samples for chemical analysis. Each funnel was equipped with a screen to prevent contamination of the sample with debris. The sample collector was placed $40 \mathrm{~cm}$ above the ground surface. In 1976 only, modified Nipher gauges were installed at several sites to determine both the deposited particulate matter and the rain over the summer period. The Nipher gauge is a standard item for measuring fresh snowfall at meteorological stations, but with modifications the gauge will accumulate any dry particulates which are deposited from the air (Nyborg et a1. 1977). Other experiments established at the field sites during the 1977 field season will be described in subsequent sections of this report.

\subsubsection{Nutrient Cycling Study}

The study was established in 1976 to compare the chemical composition of throughfall, stemflow, and litterfall of several indigenous tree species of the AOSERP study area, and to evaluate the influences of atmospheric sulphur dioxide on the foliar leaching rates of these same species. The tree species studied were black spruce (Picea mariana (Mi11.) B.S.P.), jack pine (Pinus banksiana Lamb.), and trembling aspen (Populus tremuloides Michx.). The three species were chosen because they are the predominant tree species in the region and because they represent three different types with regard to tree form, bark texture, and site preferences.

It should be noted that in the AOSERP study area, there is some hybridization between jack pine and lodgepole pine (Pinus contorta Dougl. var. latifolia. Engelm.) where their ranges overlap (Hosie 1975). Branch and cone samples from all the jack pine sites used in this study were examined in the laboratory. It was evident that the variability between sites was no greater 
than the natural variability of jack pine populations. The jack pine trees at each site exhibited predominantly jack pine characteristics. In further discussion in this report, these hybrid trees will be referred to as jack pine. Two study sites were chosen in 1976. The "control site" was established near the Algar forestry air strip (Site No. 13) $101 \mathrm{~km} \mathrm{SSW} \mathrm{of} \mathrm{the}$ emission source. The "exposed site" was situated near Site No. 4 at $32 \mathrm{~km} \mathrm{SE}$ of the emission source (Figure 2). At each site, three plots were established, one for each species. Thus, there were three control plots and three exposed plots.

It was not possible to have two plots for each species at each of the control and exposed sites. Difficulty in locating similar stands, lack of time to establish the plots, and the prohibitive number of sample collectors, precluded the use of this more desirable experimental design.

Each plot consisted of a pure stand of each tree species. A description of the study plots is given in Table 2. Ten trees were sampled in each plot. For jack pine and trembling aspen the control and exposed plots had similar tree heights and stand densities. The difference in the diametres of trees selected for stemflow gauges was significant (Student's t-test) for trembling aspen $(p<0.05)$ but was not significant for jack pine. The spruce plots were quite different in stand density, tree heights and stem diameters.

At both exposed and control sites, plots were chosen to be as close together as possible. This minimized topographic differences and ensured each plot received similar amounts of precipitation. This also ensured that the exposed plots received similar levels of sulphur dioxide emissions.

Each plot (except the exposed black spruce plot) measured $30 \mathrm{~m} \times 30 \mathrm{~m}$ (approximately $0.1 \mathrm{ha}$ ) and was divided into 36 quadrats of $5 \mathrm{~m} \times 5 \mathrm{~m}$. Twenty of the quadrats were selected using a random number table and a throughfall gauge was set up in the centre of each (Figure 3 ). The throughfall collectors consisted of $5 \mathrm{~L}$ polyethylene bottles fitted with polyethylene funnels with an inside diameter of $21 \mathrm{~cm}$. On plots where the crown closure was less than $80 \%$, throughfall gauges were placed under the tree nearest the centre of the quadrat. This was to ensure that there was an adequate number of collectors to obtain samples of throughfall. Ten stemflow collectors were attached to randomly selected trees in each experimental plot 


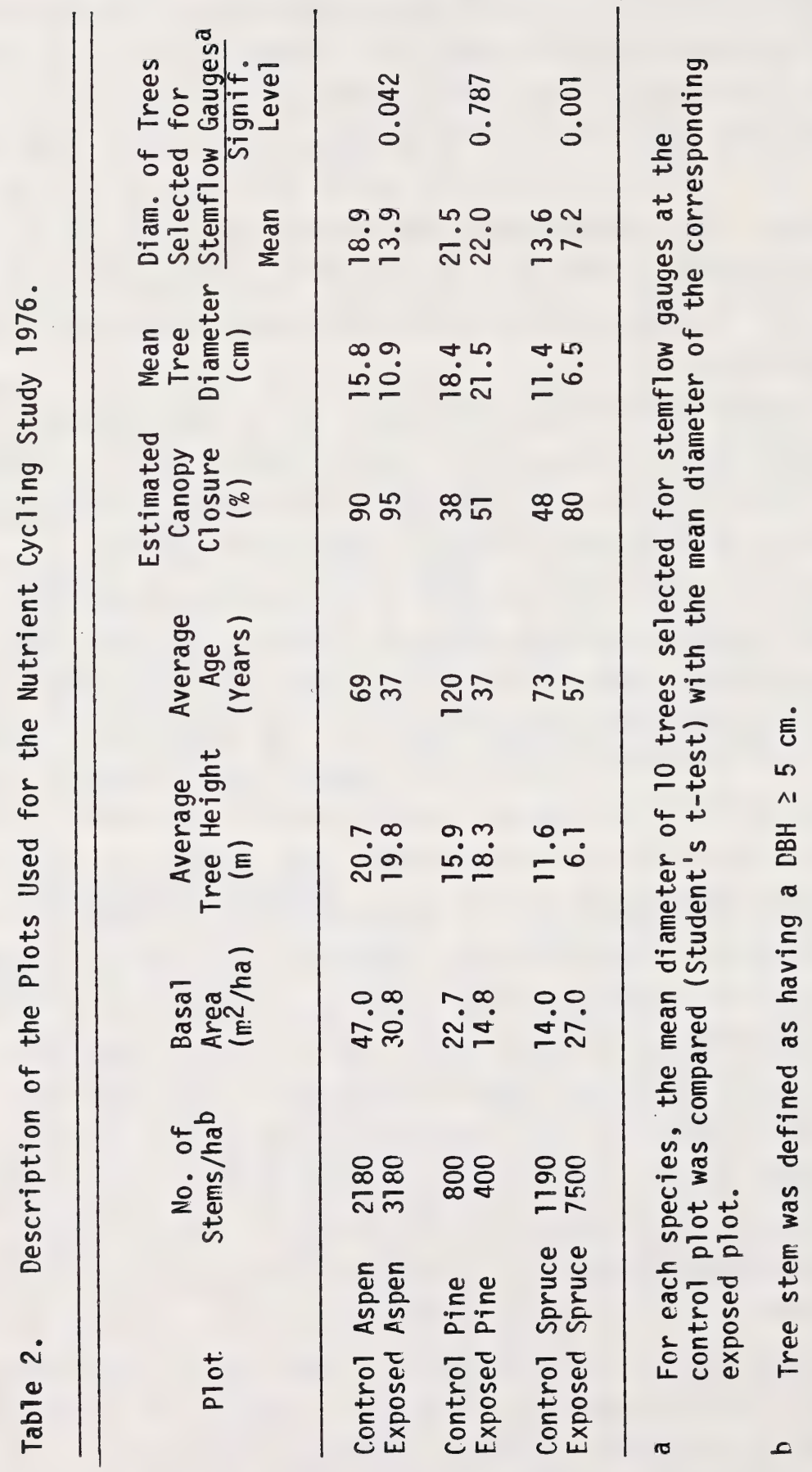




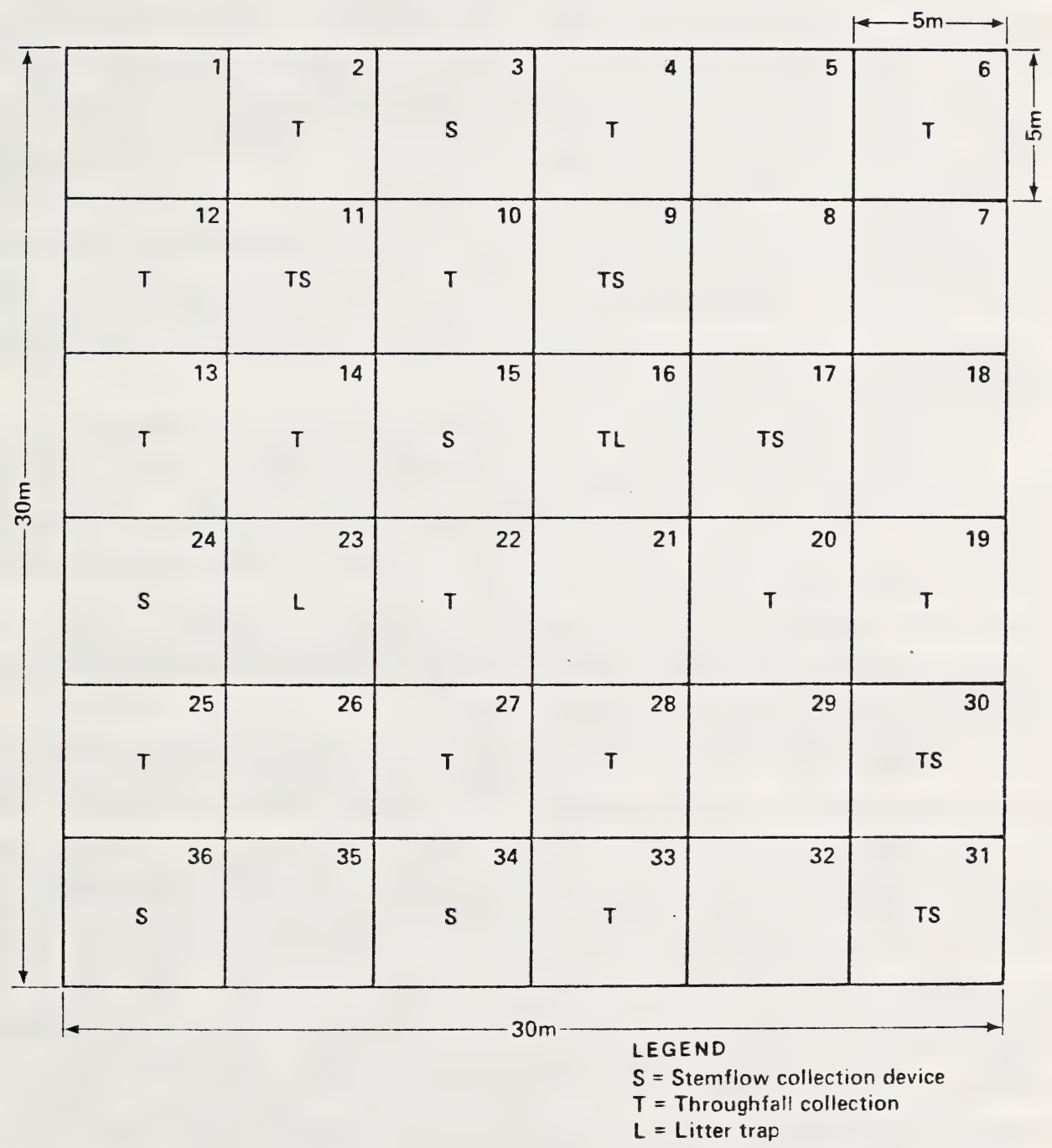

Fiqure 3. Layout of a Typical Plot Used in the Nutrient Cyclino Study. 
(Figure 3 ). The stemflow collectors consisted of split plastic piping fastened to the tree in a spiral fashion and sealed with an inert caulking compound. The piping led into $23 \mathrm{~L}$ polyethylene "jerry" cans placed on the ground. Each device was fited with a nylon screen to trap out insects and other debris. Two litter traps were randomly positioned in each plot (Figure 3). The litter traps were made up of $1 \mathrm{~m} \times 1 \mathrm{~m} \times 15 \mathrm{~cm}$ wooden frames with fine (18 mesh) fiberglass screen bottoms. They were set on legs $15 \mathrm{~cm}$ above the ground surface. This number of collection devices per plot (20 throughfall, 10 stemflow, and 2 litter) was considered the minimum necessary for comparisons to be made between the plots at a reasonable confidence level (Kimmins 1973).

The black spruce exposed plot measured $20 \mathrm{~m} \times 20 \mathrm{~m}$ and had a narrow path cut through the centre and around the outside edges to provide access for sampling. This plot design was necessary because the density of the trees made a larger plot difficult to set up. Each $5 \mathrm{~m} \times 5 \mathrm{~m}$ quadrat was divided into four subquadrats and a throughfall collector was positioned in two of these by random selection. The stemflow collection devices and litter traps were positioned as for the other plots.

Each plot had two rain gauges in a nearby clearing and a rain collection gauge to provide samples of incident rain for chemical analysis. The rain gauges were Taylor 11 inch "clear-vu" rain gauges (Sybon Corporation N.C.). They were positioned approximately $40 \mathrm{~cm}$ above the ground surface. The rain sample collectors consisted of $5 \mathrm{~L}$ polyethylene bottles fitted with polyethylene funnels with an inside diameter of $21 \mathrm{~cm}$. Each funnel was equipped with a fine mesh screen to prevent debris from contaminating the samples. The collection devices were placed inside wooden boxes attached to wooden stakes so that the gauges were approximately $40 \mathrm{~cm}$ above the ground surface. Sulphation discs were also located at each plot in a wooden shelter box located in an adjacent opening.

\subsubsection{Jack Pine Stemflow Study}

In June 1977, four sites were established to study the influence of sulphur dioxide emissions on the chemical composition of jack pine stemflow. Data from the 1976 nutrient cycling study had shown that there was a marked 
depression in the pH of jack pine stemflow and throughfall at the site exposed to sulphur dioxide. Further investigation was needed.

The two control sites were located near field site No. 13, $27 \mathrm{~km}$ south of field site No. 14. The site south of site No. 14 is referred to as site No. 14A and named May 2 (Table 3), al thought that site does not appear on Figure 2. The two exposed sites were located at site No. 8 , about $1.6 \mathrm{~km}$ northwest of site No. 6 . The site near site No. 6 is referred to as site No. 6A and named Steepbank 3 (Table 3), but does not appear on Figure 2. The sites were located at least $300 \mathrm{~m}$ from the highway to prevent contamination of the rain samples by motor vehicle exhaust fumes.

Pure stands of jack pine were chosen for each plot. A description of the sites is given in Table 3. At each site, stemflow collector devices were attached to five randomly selected trees. Rain gauges, rain sample collection gauges, and sulphation discs were set out at each site as for the 1976 nutrient cycling study (Section 3.1.2).

\subsubsection{Movement of Applied Sulphate Sulphur in Forest Soils}

The experiment was established to determine the rate of movement of sulphate sulphur through natural undisturbed soils of the AOSERP study area. There were sites for the experiment (Figure 4).

3.1.4.1 Mildred Lake Research Facility Site. The site is located $11 \mathrm{~km}$ northwest of the emission source on well-drained aeolian sand. The principal tree species is jack pine with a sparse understory of bearberry

(Arctostaphyios uva-ursi (L.) Spreng.), bog cranberry (Vaccinium vitis-idaea (L.) var. minus Lodd), and blueberry (Vaccinium myrtilloides Michx.). There is also a nearly continuous lichen stratum principally of Cladina mitis (Sandst.) Hale \& W. Culb.) and Cladina arbuscula (Wallr.) Hale and W. Culb.

3.1.4.2 Ruth Lake Site. The site is located $6 \mathrm{~km}$ south of the emission source on poorly-drained aeolian sand with a water table situated less than $1 \mathrm{~m}$ from the surface during the summer months.

Vegetation consists of scattered individuals of jack pine seedlings with a low shrub stratum comprised of mainly leather leaf (Chamaedaphne 
16

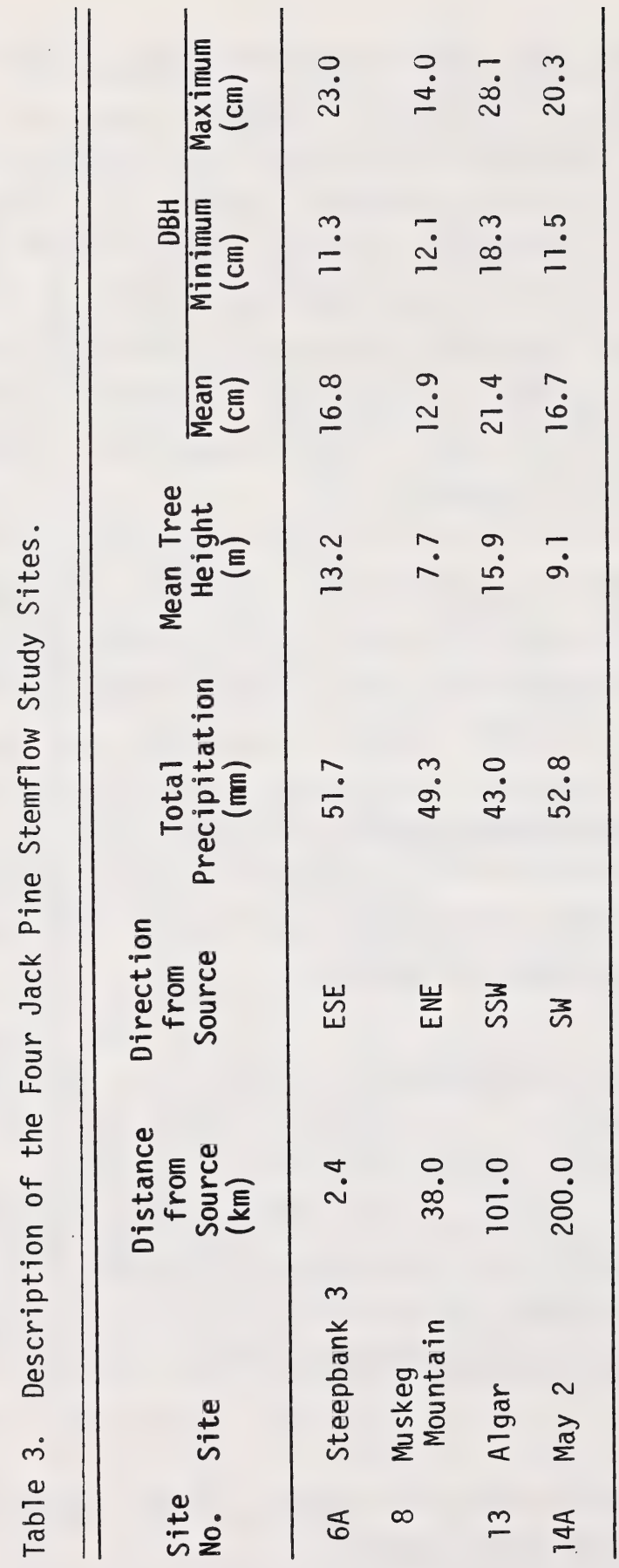




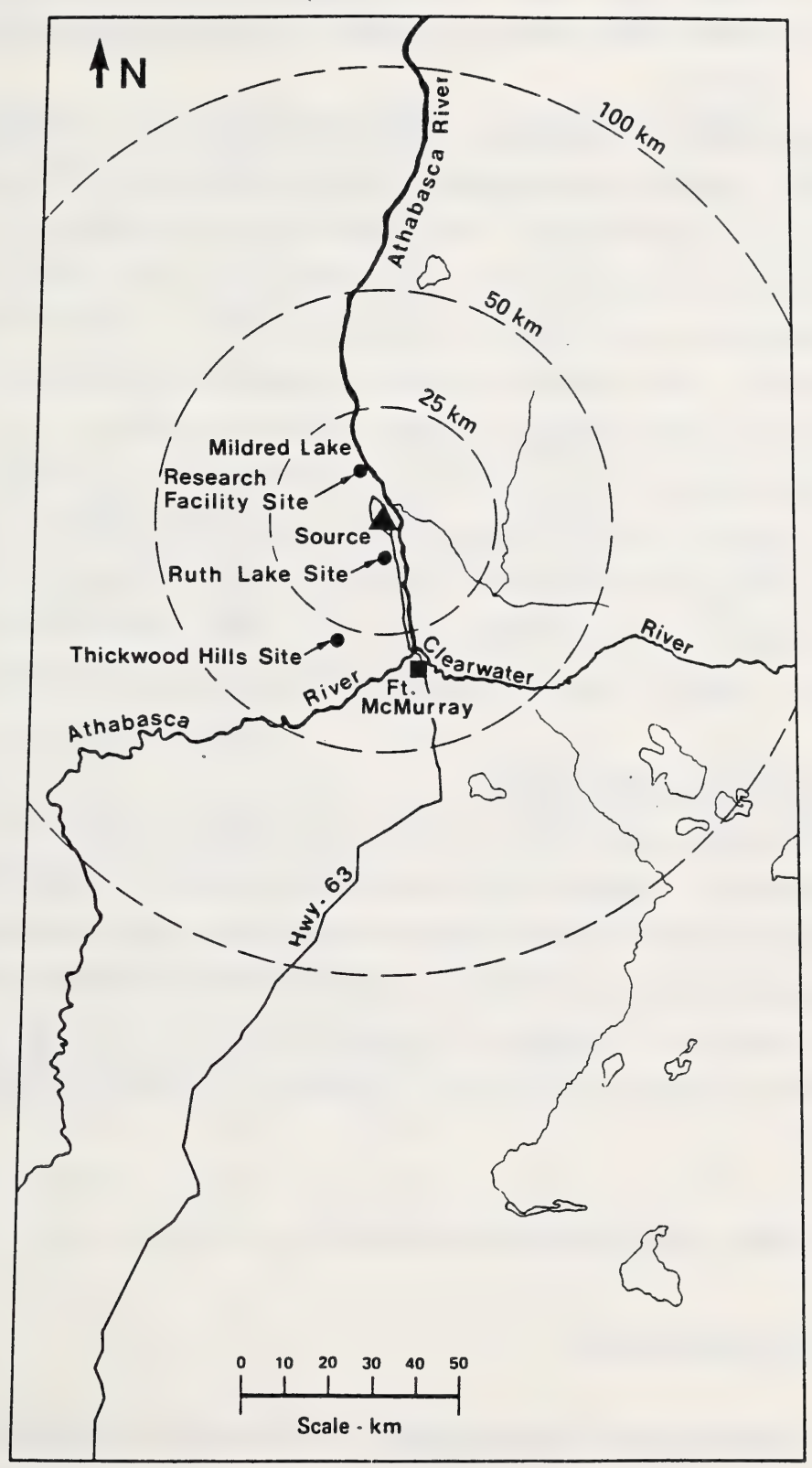

Figure 4. Location of Three Sites with Experimental Plots on Undisturbed Soil, with Applications of Elemental Sulphur, Sulphuric Acid, and Potassium Sulphate. 
calyculata Moench.) and bog rosemary (Andromeda polifolia L.). The bryophyte stratum is diverse but consists mainly of Polytrichum strictum Brid.

3.1.4.3 Thickwood Hills Site. The site is a well-drained upland site on glacial till located approximately $27 \mathrm{~km}$ southwest of the emission source. The tree species present are 1 arge jack pine individuals in a dense stand of smaller trembling aspen trees. There are also a few small white spruce trees. The sparse tall shrub stratum consists of green alder (Alnus crispa (Ait.) Pursch). The lichen stratum is almost continuous and comprised principally of Cladina mitis (Sandst.) Hale \& W.Culb.

The texture and bulk density of the soils at these sites is given in Table 4. The soils at the Mildred Lake Research Facility and Ruth Lake sites are sandy; while the soil at Thickwood Hills contains more clay. The first soil was an Orthic Eutric Brunisol. The soil at Ruth Lake site was not classified. The soil at Thickwood Hills was an Orthic Gray Luvisol.

\subsubsection{Permanent Soil Plots}

The plots were laid out in mid-August, 1976, at each of the field sites (Figure 2). These plots were established to provide baseline information on soils in the AOSERP study area, and to provide a means of monitoring the long-term effect of sulphur deposition on soils. These plots allow soil sampling from specific micro-plots $(1 \mathrm{~m} \times 2 \mathrm{~m})$ replicated three times, with allowance to take soil samples in nine different years (Figure 5).

\subsection{SAMPLE COLLECTION AND ANALYSIS}

\subsubsection{Wet Deposition}

3.2.1.1 Precipitation Measurements. The amount of precipitation at each field site was recorded during the first and second halves of each month (approximately 15 days apart) from June to September 1976. During 1977, precipitation was measured during the first week of each month from May to 
Table 4. Soil Texture and Bulk Density of Soils from Sites of the Applied Sulphur Movement Experiment.

\begin{tabular}{|c|c|c|c|c|c|c|}
\hline Sites & $\begin{array}{l}\text { Depth } \\
(\mathrm{cm})\end{array}$ & $\begin{array}{l}\text { Sand } \\
(\%)\end{array}$ & $\begin{array}{l}\text { Silt } \\
(\%)\end{array}$ & $\begin{array}{l}\text { Clay } \\
(\%)\end{array}$ & $\begin{array}{l}\text { Textural } \\
\text { Class }\end{array}$ & $\begin{array}{l}\text { Bulk } \\
\text { Density } \\
\left(\mathrm{g} / \mathrm{cm}^{3}\right)\end{array}$ \\
\hline \multirow{5}{*}{$\begin{array}{l}\text { Mildred Lake } \\
\text { Site }\end{array}$} & 0.0 to 2.5 & 93.0 & 2.7 & 4.3 & $S$ & 1.28 \\
\hline & 2.5 to 15 & 89.8 & 4.9 & 5.3 & $S$ & 1.72 \\
\hline & 15 to 30 & 91.8 & 2.8 & 5.4 & $S$ & 1.96 \\
\hline & 30 to 60 & 93.4 & 0.4 & 6.2 & $S$ & 2.12 \\
\hline & 60 to 90 & 92.0 & 1.7 & 6.3 & $S$ & 2.33 \\
\hline \multirow{5}{*}{$\begin{array}{l}\text { Ruth Lake } \\
\text { Site }\end{array}$} & 0.0 to 2.5 & 89.6 & 3.7 & 6.7 & $S$ & 1.50 \\
\hline & 2.5 to 15 & 93.4 & 0.4 & 6.2 & $S$ & 1.76 \\
\hline & 15 to 30 & 90.5 & 1.0 & 8.5 & $S$ & 1.97 \\
\hline & 30 to 60 & 92.4 & 0.7 & 6.9 & $S$ & 2.12 \\
\hline & 60 to 90 & 92.1 & 0.6 & 7.3 & $S$ & 2.23 \\
\hline \multirow{4}{*}{$\begin{array}{l}\text { Thickwood } \\
\text { Hills Site }\end{array}$} & 0.0 to 2.5 & 33.3 & 48.8 & 17.8 & $L$ & 1.00 \\
\hline & 2.5 to 15 & 27.6 & 27.2 & 45.2 & $\mathrm{CL}$ & 1.23 \\
\hline & 15 to 30 & 32.0 & 32.6 & 35.4 & $\mathrm{CL}$ & 1.44 \\
\hline & 30 to 60 & 63.5 & 25.2 & 11.3 & $S C L$ & 1.55 \\
\hline
\end{tabular}


Replicate 1 Replicate 2 Replicate 3

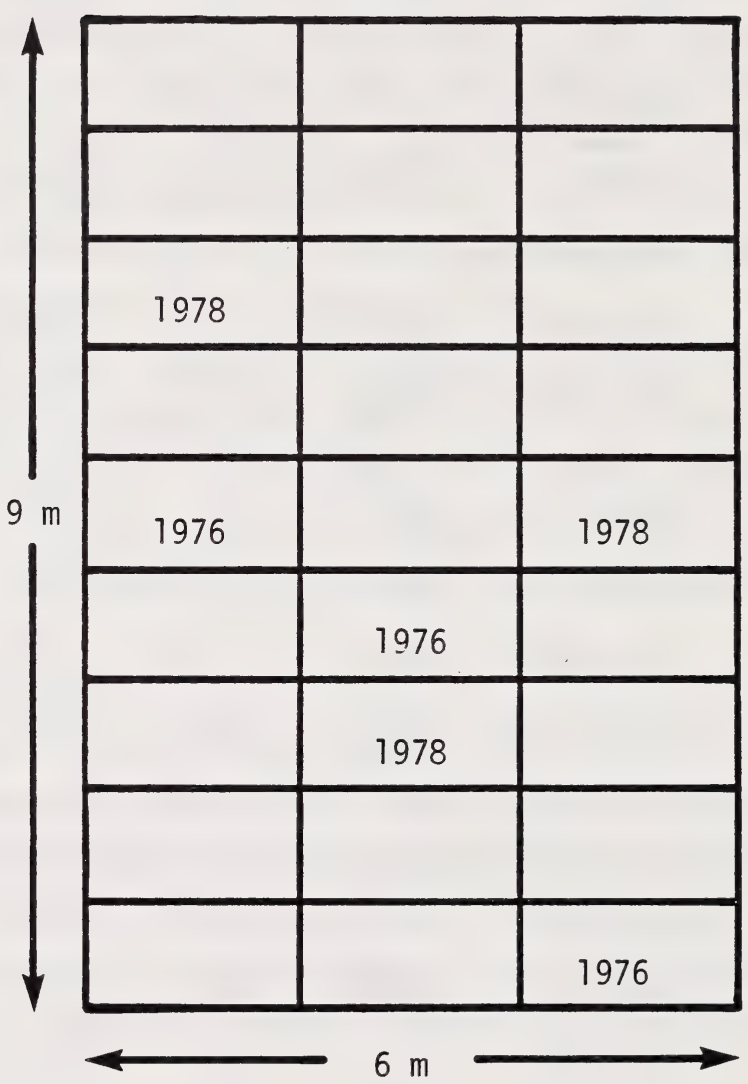

Fiqure 5. Field Plan of a Permanent Soil Plot. Samples were taken in 1976 and 1978. 
September. Small quantities of mineral oil was placed in the emptied rain gauges after measurements were obtained to minimized evaporation between readings.

3.2.1.2 Precipitation Sampling. Incident rain samples were collected from the rain funnel-type sample gauge at each field site at the same time as the rain gauge was read. The volume of the rain sample was recorded and a $250 \mathrm{~mL}$ sample taken. Samples were stored in the dark at $0^{\circ} \mathrm{C}$ to $+4^{\circ} \mathrm{C}$ so that any growth of microorganism would be reduced until analyses were completed. Samples were filtered before the analyses.

The rain samples from the Nipher gauges, which included deposted water-soluble particulate matter, were handled in a similar way as the rain from the funnel-type gauges. The sulphate sulphur content of the Nipher sample minus the sulphate sulphur content of the funnel-type gauge gave the estimate of the amount of sulphate sulphur in dry deposition.

Accumulated snow samples were collected in 1976 March 17 and 18 at seven sites in the AOSERP study area. Duplicate samples were taken at each site. Snow volume per unit area was measured. The $\mathrm{pH}$, sulphate sulphur concentrations, and cation content were determined on the melted samples. The cations $\mathrm{Ca}^{2+}, \mathrm{Mg}^{2+}, \mathrm{Na}^{+}$, and $\mathrm{K}^{+}$were determined by atomic absorption using a Perkin-Elmer model 503 atomic absorption spectrophotometer with an air-acetylene flame. Samples for $\mathrm{Ca}^{2+}$ and $\mathrm{Mg}^{2+}$ determination were first diluted with $1 \% \mathrm{La}_{2} \mathrm{O}_{3}$ solution to reduce chemical interference. The $\mathrm{pH}$ of precipitation samples was determined using a Fisher Acumet model 250 digital $\mathrm{pH}$ meter.

Sulphate sulphur was determined using Dean's (Dean 1966) modification of the spectrophotometric method of Johnson and Nishita (1952). Precision of the determination of sulphur sulphate normally fell within $\pm 5 \%$ of the average, but when the concentration of sulphur sulphate in precipitation samples was less than $0.5 \mathrm{ppm}$, precision was only $\pm 10 \%$.

3.2.1.3 Nutrient Cycling Study. Throughfall and stemflow were sampled approximately every two weeks for the control plots and monthly for the exposed plots. The exposed plots were sampled less frequently than the 
control plots because the only means of access to the exposed plots was by helicopter. Sampling frequency was increased with more frequent rain storms.

On each sample date, the volume of water in each collector was recorded and a $250 \mathrm{~mL}$ sample taken. Rain water samples were collected in a similar fashion. The filters were cleaned at each sampling and $1 \mathrm{~mL}$ of chloroform was added to the polyethylene collection vessels and the sample bottles to prevent algal growth (Carlisle et al. 1966).

The $\mathrm{Ca}^{2+}, \mathrm{Mg}^{2+}, \mathrm{Na}^{+}, \mathrm{K}^{+}$, and $\mathrm{SO}_{4}{ }^{2-}-\mathrm{S}$ concentrations were determined as for the precipitation samples (Section 3.2.1.2). The mean nutrient concentrations presented are geometric means with each concentration value being weighted according to the sample volume. To calculate such a mean for the $\mathrm{pH}$ values, the $\mathrm{pH}$ numbers were first converted to their negative antilogarithms (hydrogen ion concentration). These were then multiplied by the sample volume and summed. This sum was divided by the sum of the sample volumes and the resulting concentration value was converted back to a $\mathrm{pH}$ value. This $\mathrm{pH}$ represents the strength of a solution of a completely ionized acid which could have brought the same amount of hydrogen ions per unit area to the ground as was brought by the rainfall.

The $\mathrm{pH}$ was determined using glass electrodes. Titratable acidity was determined by titrating a $25 \mathrm{~mL}$ aliquot of the degassed sample against $0.001 \mathrm{~N} \mathrm{KOH}$ (standardized against $\mathrm{H}_{2} \mathrm{SO}_{4}$ ) to $\mathrm{pH} 7.00$ using a combination glass electrode and a Fisher automatic titrimetre.

It should be noted here that in any water sample there are two types of acidity that can be measured, free and total. Free acidity is a measure of the concentration of protons in solution. They could have originated from the dissociation of weak or strong acids. Free acid is determined by measurement of the solution pH. Total acidity is determined by titration and is a measure of the concentration of protons, both those in solution and those still undissociated.

\subsubsection{Jack Pine Stemflow Study. Stemflow was collected on three} occasions during the summer of 1977: (1) 19 to 20 May; (2) 06 to 07 June; and (3) 03 to 05 July. At each sample period all four sites were serviced. The amount of precipitation was recorded at each sample date and a sample of 
rainwater was collected from the rain sample collection gauge. The volume of stemflow was recorded and a $250 \mathrm{~mL}$ subsample taken for analysis. The $\mathrm{pH}$, titratable acidity, and $\mathrm{SO}_{4}{ }^{2-}-\mathrm{S}$ were determined on all samples as for the nutrient cycling study samples (Section 3.2.1.3).

\subsubsection{Dry Deposition}

3.2.2.1 Sulphur Dioxide Absorption by Sulphation Discs. Two sulphation discs were maintained under the rain shelter at each field site during the summer of 1976 and 1977. Each consisted of plastic petri dishes of $4.8 \mathrm{~cm}$ inside diameter and contained a $\mathrm{PbO}_{2}$ compound.

The discs were left for an exposure period of one month at each field site before being replaced by fresh discs. They were analysed for sulphur by digesting the insoluble lead sulphate with sodium carbonate and then the $\mathrm{SO}_{4}{ }^{2-}-\mathrm{S}$ was determined by the method of Johnson and Nishita (1952). The data were expressed as $\mathrm{mg} \mathrm{SO}_{3}$ per $100 \mathrm{~cm}^{2}$ of plate surface area per day.

3.2.2.2 Sulphur Uptake by Bare Soils - Field Experiments. In 1975, a peat and two mineral soils from the AOSERP study area, and three agricultural soils were set out in canisters at a number of different sites. The purpose of this experiment was to measure the amounts of sulphur absorbed directly from the air by soils in the AOSERP study area and to measure the effect of this absorbed sulphur on soil pH. Agricultural soils were used to provide a simple means of comparison with studies elsewhere in the province. The soils were as follows:

1. Soil 1: An Orthic Black Chernozem, Malmo series, silty clay loam texture, $10 \%$ organic matter. The soil is cultivated, and the sample was taken from the cultivated layer. This soil will be referred to as $0 . B L$ soil.

2. Soil 2: An Orthic Dark Gray Chernozem, silty loam texture. The soil is cultivated, and the sample was taken from the cultivated layer. This soil will be alternatively referred to as $0 . D G$ soil. 
3. Soil 3: An Orthic Black Chernozem, sandy loam texture. The soil is cultivated, and the sample was taken from the cultivated layer. This soil will be alternatively referred to as the sandy O.BL soil.

4. Soil 4: An Orthic Eutric Brunisol, sand texture. Sample taken approximately $2 \mathrm{~km}$ south from the AOSERP Mildred Lake Research Facility Site. Tree cover was jack pine. The soil sample was obtained from the top $25 \mathrm{~cm}$ of the Bm horizon. This soil will be alternatively referred to as the sandy O.EB soil.

5. Soil 5: An Orthic Gray Luvisol, sandy loam texture. Sample taken approximately $5 \mathrm{~km}$ north of Fort Mackay. Tree cover was trembling aspen. Sample was taken from the top $15 \mathrm{~cm}$. The soil will be alternatively referred to as the $0 . \mathrm{GL}$ soil.

6. Soil 6: A Typic Mesisol. sample was taken $25 \mathrm{~km}$ south of Fort Mackay. The soil be alternatively referred to as the TY.M soil.

Soils were ground to pass through a $2 \mathrm{~mm}$ sieve and equal weights of each soil were $\mathrm{placed}$ in canisters of dimensions $9.5 \mathrm{~cm} \times 9.5 \mathrm{~cm} \times 13.5 \mathrm{~cm}$. The soil surface area exposed to the air was therefore $90.3 \mathrm{~cm}^{2}$. Three canisters of each soil were placed under the rain shelter at each field site. This was to ensure that the only source of sulphur for the soils was that in the ambient air. The rain shelter was open on all sides so as to provide unrestricted air flow over the soil samples. Most of these soils were brought to field capacity water content weekly by addition of distilled $\mathrm{H}_{2} \mathrm{O}$. A few were kept air-dry at all times.

In 1976, the above experiment was repeated with more sites. In this report, however, results are given only for the sandy O.EB soil and the TY.M soil. Soils were set out in canisters at each of 14 field sites from June to September. The soils were watered twice a month to $10 \%$ above their predetermined field capacity moisture content with distilled water.

After the summer exposure period, the soil canisters were returned to the lahoratory and the soils were separated into layers: (1) 0 to $1 \mathrm{~cm}$; (2) 1 to $3 \mathrm{~cm}$; (3) 3 to $5 \mathrm{~cm}$; and (4) 5 to $12 \mathrm{~cm}$. They were then air dried. The pH was determined using a Fisher Acumet $250 \mathrm{pH}$ metre. The soil:water and 
peat:water ratios used were $20 \mathrm{~g}$ soil:50 $\mathrm{mL}$ water and $2 \mathrm{~g}$ peat:50 $\mathrm{mL}$ water, respectively. Soluble sulphate was extracted by shaking with $0.1 \mathrm{M} \mathrm{CaCl}_{2}$ for 30 minutes. The mixture was then filtered (Whatman No. 40) and the $\mathrm{SO}_{4}{ }^{2-}$-S content of the filtrate was determined by the method of Johnson and Nishita (1952). The extractant ratios used were $10 \mathrm{~g}$ soil:20 $\mathrm{mL} \mathrm{CaCl}{ }_{2}$, and $2 \mathrm{~g}$ peat: $30 \mathrm{~mL} \mathrm{CaCl}{ }_{2}$. Total sulphur was determined by the alkaline oxidation method of Tabatabai and Bremner (1970). Soil samples were finely ground (less than $425 \mathrm{um}$ ) and 0.1 to $0.2 \mathrm{~g}$ was digested depending on the total sulphur content. Analyses were performed with a bank of six digestiondistillation units. A recovery test showed that the method used gave a 97 to $99 \%$ recovery of $\mathrm{K}_{2} \mathrm{SO}_{4}$ and elemental sulphur added to test soils. In addition, the precision of soil total sulphur determination was within $\pm 3 \%$.

\subsubsection{Sulphur Uptake by Lichen Covered Soils - Field Experiment. The} soil samples used for this experiment were obtained from an area close to field site No. 14 (Figure 2). The samples were removed from th ground in such a manner that the lichen layer on the soil sample surface remained undisturbed. A description of a typical soil sample is given in Table 5.

The intact soil samples were placed in plastic pots of $16.5 \mathrm{~cm}$ inside diameter and $13.0 \mathrm{~cm}$ in height. Six replicates of each were set out under the rain shelters at four of the field sites Nos. $6,8,13$, and 14 (Figure 2), from May to October, 1977. Every month the soils were brought to predetermined field capacity moisture content by the addition of distilled water.

At the end of the exposure period, the plots were sealed in plastic bags and returned to the laboratory for analysis. The lichen material and the top $2.5 \mathrm{~cm}$ of soil were separated, dried, ground, and analysed for $\mathrm{pH}$, $\mathrm{Sn}_{4}{ }^{2-}-\mathrm{S}$, and total $S$ as for the bare soil experiment (Section 3.2.2.2). Results were expressed on an area basis $(\mathrm{kg} / \mathrm{ha})$ by multiplying the results in ug/g soil by the soil bulk density and exposed surface area.

\subsubsection{Sulphur Uptake by Lichen Covered Soils - Controlled Atmosphere}

Experiment. Intact lichen covered soil samples taken from an area near field site No. 12 (Figure 2) were $\mathrm{placed}$ into round plastic containers $11 \mathrm{~cm}$ in 
Table 5. Analysis of Lichen Covered Soils Used in a Field Experiment on Sulphur Uptake by Undisturbed Soils.

\begin{tabular}{lccccccc}
\hline Horizon & $\begin{array}{c}\text { Thickness } \\
(\mathrm{cm})\end{array}$ & $\mathrm{pH}$ & $\begin{array}{l}\text { Sand } \\
(\%)\end{array}$ & $\begin{array}{l}\text { Silt } \\
(\%)\end{array}$ & $\begin{array}{c}\text { Clay } \\
(\%)\end{array}$ & $\begin{array}{c}\text { Bulk } \\
\text { Density } \\
\left(\mathrm{g} / \mathrm{cm}^{3}\right)\end{array}$ & $\begin{array}{c}\text { Organic } \\
\text { Matter } \\
(\%)\end{array}$ \\
\hline Lichen & 3.8 & 4.5 & N/Aa & N/A & N/A & 0.02 & N/A \\
LFH & 0.5 & 4.1 & N/A & N/A & N/A & 0.53 & 15.2 \\
Ae & 8.0 & 4.6 & 51.5 & 37.5 & 11.0 & 0.95 & NDb \\
\hline
\end{tabular}

a $\quad$ N/A $=$ Not Applicable.

b $\quad$ ND $=$ No Data. 
diameter and $6.5 \mathrm{~cm}$ high. The soil used was sandy in texture with a thin $\mathrm{FH}$ horizon ( $5 \mathrm{~mm}$ ) below the lichen cover (Table 6 ).

Samples were exposed to sulphur dioxide for seven days in a controlled atmosphere apparatus (Figure 6 ). The average air flow rate used was $685 \mathrm{~L} / \mathrm{hr}$ and the average air temperature was $22^{\circ} \mathrm{C}$. The average sulphur dioxide concentration in the exposure chamber was $100 \mathrm{ppb}$. Similar samples were $\mathrm{placed}$ in a chamber which had identical conditions except sulphur dioxide was excluded -- this served as a control. The experiment was conducted at both high $(80 \%)$ and 1 ow $(20 \%)$ relative humidity to determine the effect of air moisture levels on soil sulphur uptake. There were six replicated used for each run.

After the exposure period the soils were divided into two layers, lichen material, and the top $2.5 \mathrm{~cm}$ of soil (including then thin $\mathrm{FH}$ horizon). These were air dried, ground, and analysed for $\mathrm{pH}_{3} \mathrm{SO}_{4}{ }^{2-}-\mathrm{S}$, and total $\mathrm{S}$ as for the bare soils experiment (Section 3.2.2.2).

\subsubsection{Movement of Applied Sulphate Sulphur in Forest Soils}

3.2.3.1 Treatments. A11 three sites received the following treatments on 1976 June 30 :

$$
\begin{aligned}
\mathrm{T} 1 & =\text { nil } \\
\mathrm{T} 2 & =56 \mathrm{~kg} \mathrm{~S} / \mathrm{ha} \text { as } \mathrm{K}_{2} \mathrm{SO}_{4} \\
\mathrm{~T} 3 & =112 \mathrm{~kg} \mathrm{~S} / \mathrm{ha} \text { as } \mathrm{K}_{2} \mathrm{SO}_{4}
\end{aligned}
$$

The $\mathrm{K}_{2} \mathrm{SO}_{4}$ was applied as crystals broadcast by hand. At the Thickwood Hills site, each treatment was replicated three times while at the other sites (Mildred Lake Research Facility and the Ruth Lake sites) there were four replicates of each treatment (see Section 3.1.4 for site descriptions).

3.2.3.2 Soil Sampling and Analysis. A custom made soil sampler of $3.5 \mathrm{~cm}$ core diameter was used for taking the soil samples. The soil was sampled by depth as follows: 
Table 6. Analysis of Lichen Covered Soils Used in the Controlled Atmosphere Experiment on Sulphur Uptake by Undisturbed Soils.

\begin{tabular}{lccccccc}
\hline Horizon & $\begin{array}{c}\text { Thickness } \\
(\mathrm{cm})\end{array}$ & $\mathrm{pH}$ & $\begin{array}{c}\text { Sand } \\
(\%)\end{array}$ & $\begin{array}{c}\text { Silt } \\
(\%)\end{array}$ & $\begin{array}{l}\text { Clay } \\
(\%)\end{array}$ & $\begin{array}{c}\text { Bulk } \\
\text { Density } \\
\left(\mathrm{g} / \mathrm{cm}^{3}\right)\end{array}$ & $\begin{array}{c}\text { Organic } \\
\text { Matter } \\
(\%)\end{array}$ \\
\hline Lichen & 5.0 & 4.1 & N/A & N/A & N/A & 0.02 & N/A \\
FH/Ae & 2.5 & 4.7 & 90.5 & 2.2 & 7.3 & 1.07 & 5.7 \\
\hline
\end{tabular}

a $\quad$ N/A $=$ Not Applicable. 


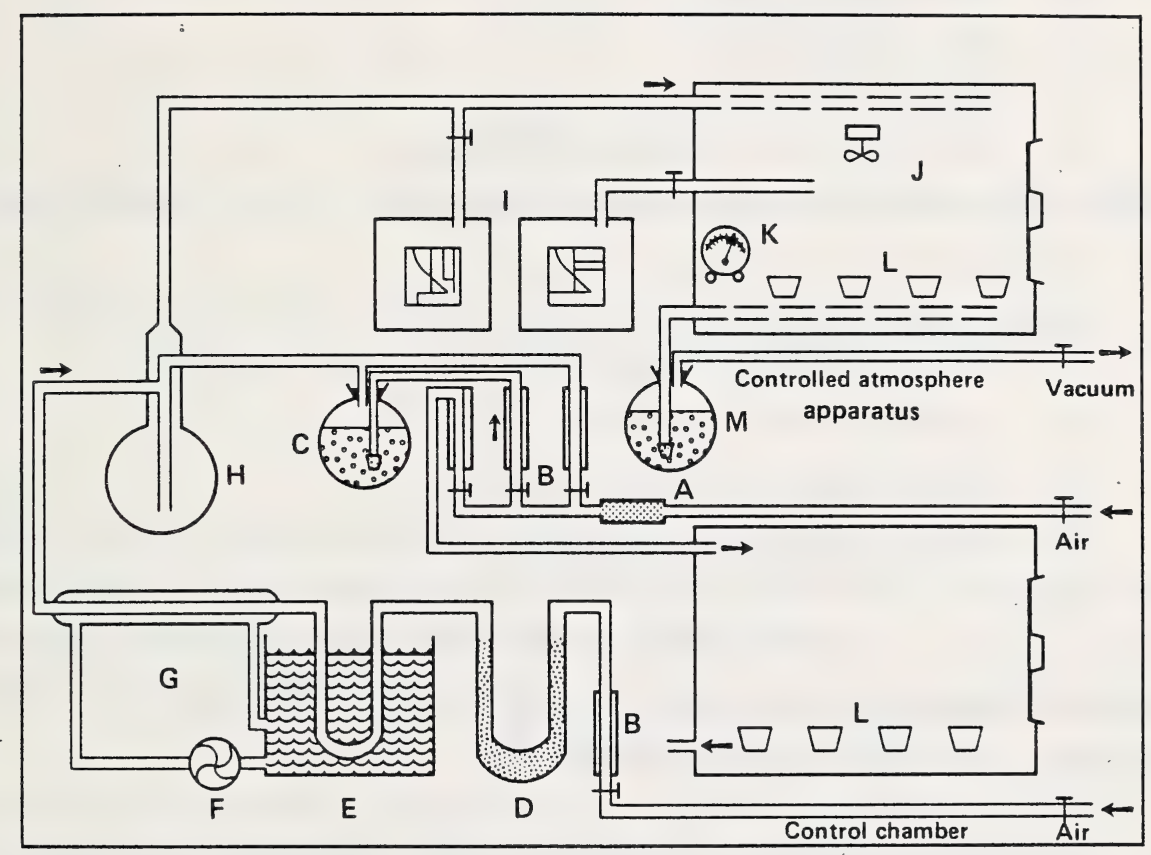
A. Air drying agent (silica gel)
B. Flowmeters
C. Air saturator
D. $\mathrm{SO}_{2}$ absorbing crystals
E. Constant temperature bath
F. Pump
G. Permeation tube chamber
H. Mixing bulb
I. $\mathrm{SO}_{2}$ Analyzers (Scientific Industries Inc. Model No. 67)
J. Fan
K. \% relative humidity meter
L. Plastic pots with lichens and soils
M. $\mathrm{SO}_{2} \operatorname{trap}\left(30 \% \mathrm{H}_{2} \mathrm{O}_{2}\right)$

Fiqure 6. Controlled Atmosphere Apparatus. 
1. 0 to $2.5 \mathrm{~cm}$;

2. 2.5 to $15.0 \mathrm{~cm}$;

3. 15.0 to $30.0 \mathrm{~cm}$;

4. 30.0 to $60.0 \mathrm{~cm}$;

5. 60.0 to $90.0 \mathrm{~cm}$; and

6. 90.0 to $120.0 \mathrm{~cm}$ (where possible)

The lichen or moss layer was sampled by removing a $15 \mathrm{~cm}$ square block with a knife.

Samples were obtained three times during the course of the experiment:

1. June 1976 (before the treatments were applied);

2. September 1976; and

3. June 1977.

Soil samples were air dried and ground (20 mesh) before analysis. Soluble sulphate and $\mathrm{pH}$ were determined as for the bare soil experiment (Section 3.2.2.2). Soluble potassium was determined from the saturated paste extract and extractable potassium was determined from the $2 \mathrm{~N} \mathrm{NaCl}$ soil extract using atomic absorption spectrophotometry.

\subsubsection{Effects of Applied Elemental Sulphur, Sulphuric Acid, and Lime on} Soil Acidity

3.2.4.1 Site Locations. Three sites were used for this experiment:

1. Mildred Lake Research Facility site;

2. Ruth Lake site; and

3. Thickwood Hills site.

The location and description of these sites are given in Figure 4 and Section 3.1.4.

3.2.4.2 Treatments. The treatments applied to the three sites are shown in Table 7. The Mildred Lake site received all the treatments while the Thickwood Hills site and the Ruth Lake site received treatments $1,3,6$, and 9 only. A11 the treatments except 4 and 7 were applied on 1976 June 30. For treatments 4 and 7, half the amounts were applied on 1976 June 30 and the remainder on 1976 September 27. A11 treatments were replicated four times. 
Table 7. Rates of Elemental Sulphur, Sulphuric Acid, and Lime Applied to the Soil.

Treatment No.

1

2

3

4

5

6

7

8

9
Treatment Description

\section{control}

elemental sulphur at $56 \mathrm{~kg} \mathrm{~S} / \mathrm{ha}+$ inoculant

elemental sulphur at $280 \mathrm{~kg} \mathrm{~S} / \mathrm{ha}+$ inoculant

elemental sulphur at $560 \mathrm{~kg} \mathrm{~S} / \mathrm{ha}+$ inoculant

$0.1 \mathrm{~N} \mathrm{H}_{2} \mathrm{SO}_{4}$ at $56 \mathrm{~kg} \mathrm{~S} / \mathrm{ha}$

$0.5 \mathrm{~N} \mathrm{H}_{2} \mathrm{SO}_{4}$ at $280 \mathrm{~kg} \mathrm{~S} / \mathrm{ha}$

$0.5 \mathrm{~N} \mathrm{H}_{2} \mathrm{SO}_{4}$ at $560 \mathrm{~kg} \mathrm{~S} / \mathrm{ha}$

lime at $2500 \mathrm{~kg} / \mathrm{ha}$

lime at $2500 \mathrm{~kg} / \mathrm{ha}+$ elemental sulphur at $280 \mathrm{~kg} \mathrm{~S} / \mathrm{ha}+$ inoculant

Notes: Elemental sulphur was very fine (passing through a sieve with 4 openings per each $\mathrm{mm}$ ) and was spread by hand. The inoculant was a water extract of a peat which had become acid because of exposure to windblown sulphur dust. For the acid treatment each plot received $21.2 \mathrm{~L}$ of the various strength acid solutions. This was equivalent to $0.3 \mathrm{~cm}$ of rain. The lime was finely ground $\mathrm{CaCO}_{3}$ (passing through a sieve with 4 openings per each $\mathrm{mm}$ ) and was spread by hand. 
3.2.4.3 Soil Sampling and Analysis. The soils were sampled and analysed for $\mathrm{SO}_{4}{ }^{2-}-\mathrm{S}$ and $\mathrm{pH}$ as for the movement of applied sulphate sulphur in forest soils experiment (Section 3.2.3.2).

\subsubsection{Lysimeter Experiment}

This experiment was conducted to determine the amounts of sulphate sulphur and cations leached from intact forest soils and to establish if there is a relationship between leaching losses of plant nutrient and sulphur deposition in the AOSERP study area.

Two soils from the AOSERP study area, a sandy Eutric Brunisol and a sandy loam Orthic Gray Luvisol, were set up in closed-bottomed lysimeters as shown in Figure 7. The lysimeters were placed on the surface of the soil. Three replicates of each soil type were set out at nine of the field sites during July 1976. The leachate was collected from July to September 1976 and from May to October 1977. The leachate was analysed for the cations $\mathrm{Na}^{+}$, $\mathrm{K}^{+}, \mathrm{Ca}^{2+}, \mathrm{Mg}^{2+}$, and $\mathrm{SO}_{4}{ }^{2-}-\mathrm{S}$ and $\mathrm{pH}$ as for the rain samples (Section 3.2.1.2).

In August 1978, the lysimeters were brought in from the various sites. Soil solums were taken apart by layers, dried, and ground for analysis. The organic horizons were separated into five components: (1) moss, (2) vascular plants, (3) lichen, (4) fresh litter (L), and (5) decomposed litter (FH). The mineral horizons were sampled by depth: (1) 0 to $3 \mathrm{~cm}$; (2) 3 to $8 \mathrm{~cm}$; (3) 8 to $15 \mathrm{~cm}$; and (4) $15^{+} \mathrm{cm}$. They were analysed for $\mathrm{pH} \mathrm{SO}_{4}{ }^{2-}-\mathrm{S}$, and total sulphur as for the other soil samples (Section 3.2.2.3). 


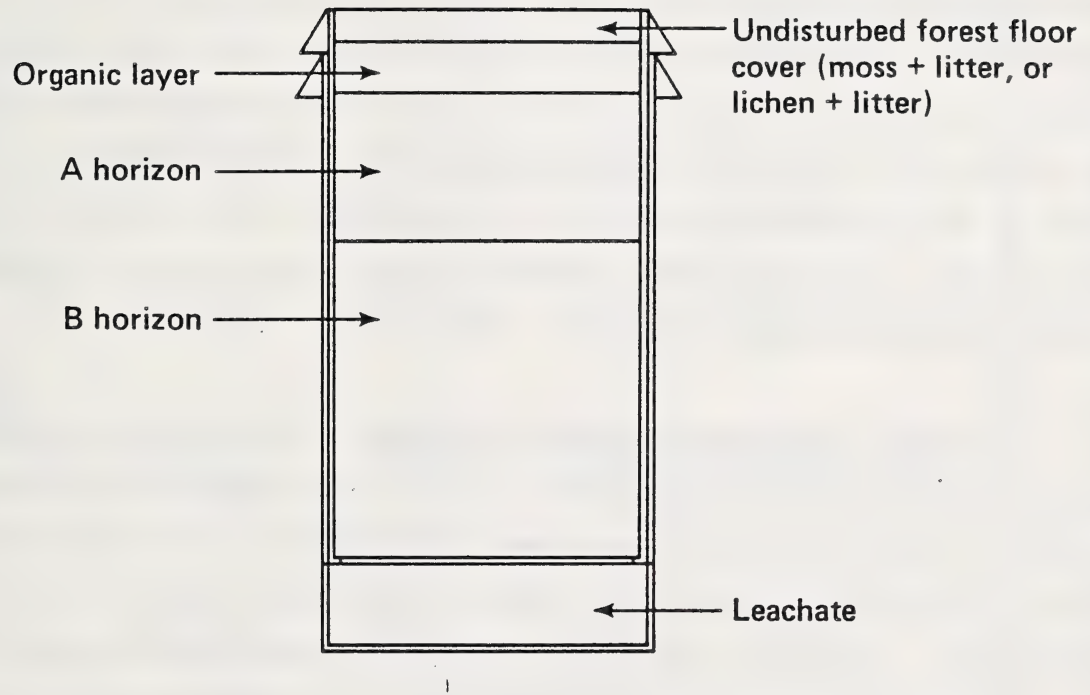

Figure 7. Lysimeter Design. Inside Diameter and Depth are $22 \mathrm{~cm}$ and $50 \mathrm{~cm}$, respectively. 
4. RESULTS AND DISCUSSION

4.1 WET DEPOSITION

4.1.1 Rain

4.1.1.1 Precipitation Pattern. The total precipitation for each month recorded at each of the field sites over the summers of 1976 and 1977 is given in Section 8.1. In general, field sites located along the river valley (Bitumount and Mackay River) received the least precipitation. The southern sites (Algar and May) and a northwestern site (Birth Mountain), which are located at the greatest elevations in the AOSERP study area, received the most precipitation. Detailed description of the climatology of the AOSERP study area was given by Longley and Janz (1978).

\subsubsection{Acidity and Sulphur Content of Rain. The pH and suiphate sulphur content of rain samples taken weekly during the summer of 1975 are given in Section 8.2. The average $\mathrm{pH}$ at sites within $25 \mathrm{~km}$ of the emission source was similar to the average $\mathrm{pH}$ at the three remote sites ( $\mathrm{pH} 6.0$ and 6.2, respectively). Sulphate sulphur concentrations at sites within $25 \mathrm{~km}$ of the emissions source averaged $1.3 \mathrm{ppm}$ compared to an average of $0.6 \mathrm{ppri}$ at the remote sites.}

The $\mathrm{pH}$ and sulphate sulphur content of rainfall samples taken monthly from 1976 June to September, are given in Table 8. Corresponding values from 1977 May to September, are given in Table 9. Field site No. 3 (Supertest $\mathrm{Hill}$ ) had consistently high $\mathrm{pH}$ and $\mathrm{SO}_{4}{ }^{2-}-\mathrm{S}$ levels. This would be due to samples at this site being contaminated with trembling aspen throughfall (Section 4.1.3). The rain sample gauge at this site was located in a small clearing in a stand of trembling aspen. Values from this site were therefore excluded in the calculation of the mean values. On several occasions, field site Nos. 1 (Mildred Lake) and 2 (Mackay River) also had high $\mathrm{pH}$ values. These high values could be because of sample contamination from alkaline dust. Both of these sites were located within $200 \mathrm{~m}$ of a gravel road. The rain gauges used were not covered between rainfall events so rain 
35

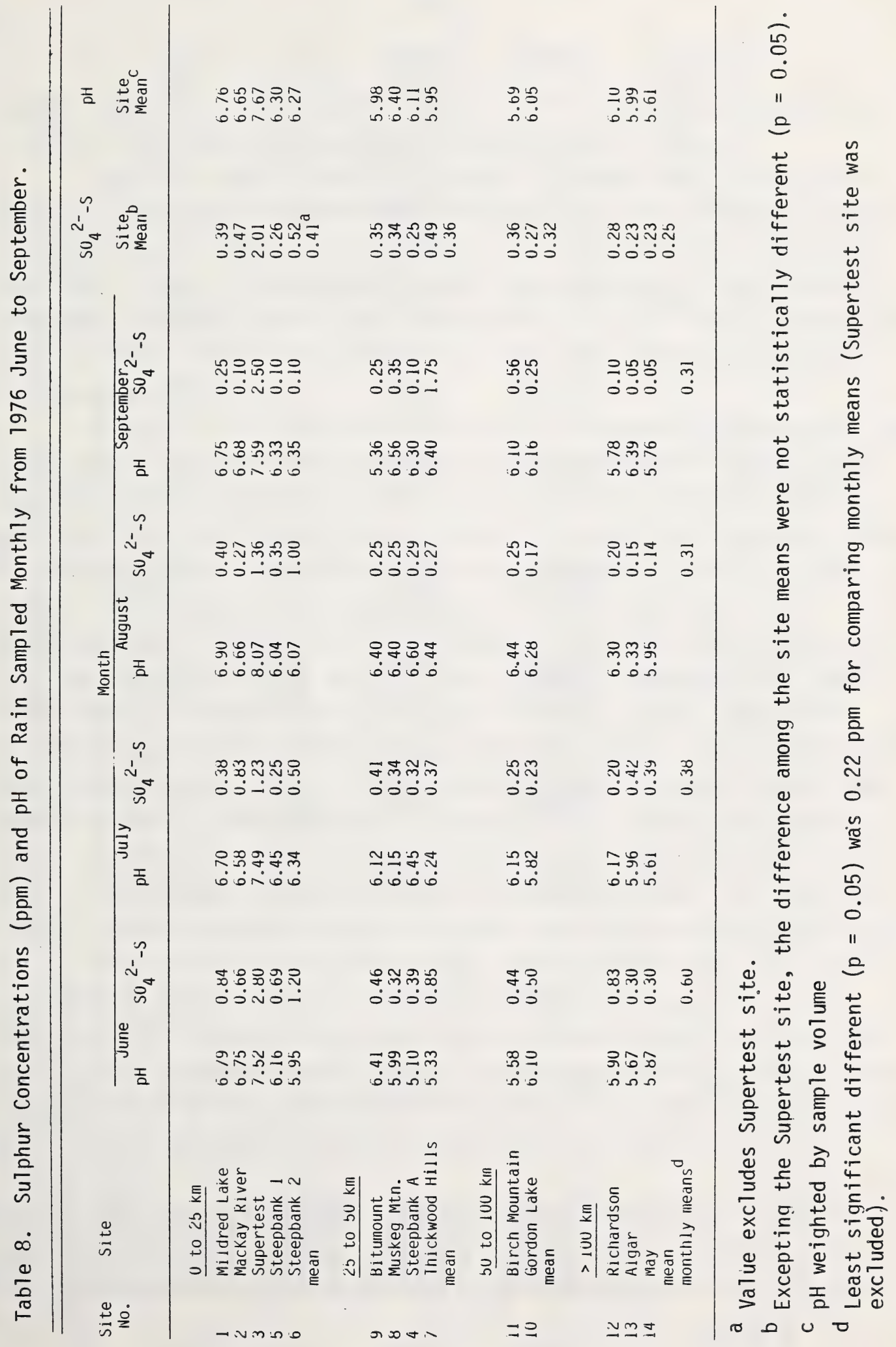




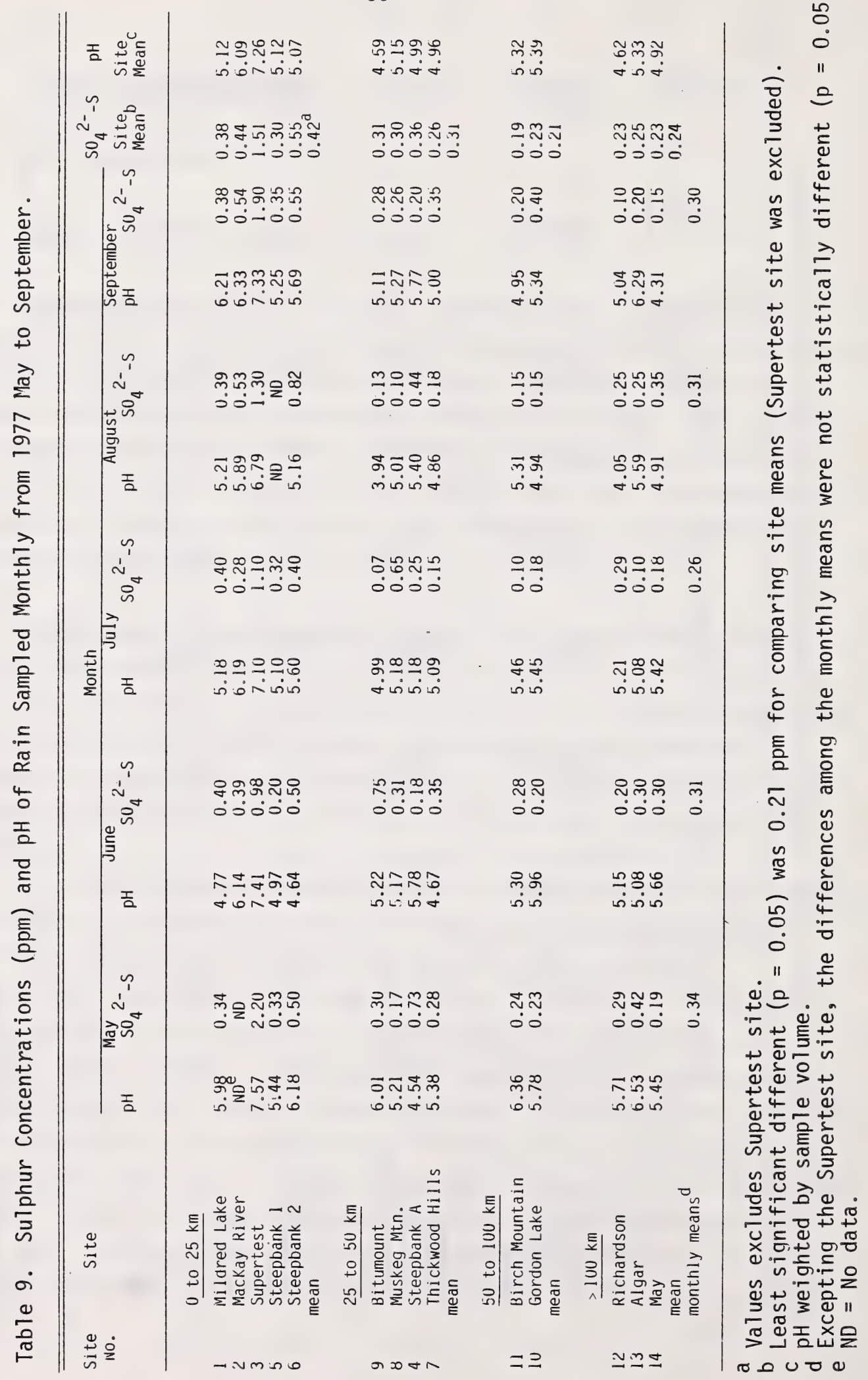


samples contained any road-derived dust, in addition to any conventional ary deposition deposited between sample collection dates.

Distilled water in equilibrium with atmospheric $\mathrm{CO}_{2}$ at $25^{\circ} \mathrm{C}$ has a $\mathrm{pH}$ of 5.7. This may be regarded as the neutral point for rainwater (Barrett and Brodin 1955). Rain was therefore acid at several sites in the AOSERP study area in 1977. A rain sample of pH 3.9 was recorded at field site No. 9 (Bitumount) in August and the July sample had a pH of 5.0. Rain samples with ph values below 5.0 were also recorded at eight other field sites on on or more occasions (Table 9).

Because of the localized nature of the plume during storm events, the sparse network of field sites, and the fact that only monthly samples were obtained, accurate interpretation of this wet deposition pattern is not possible. The network does, however, provide 'baseline' wet deposition rates of sulphate sulphur in the AOSERP study area (Section 8.2, Tables 38, 39, and 40$)$. The average monthly concentration of $\mathrm{SO}_{4}{ }^{2-}-\mathrm{S}$ in rain in the AOSERP study area ranged from 0.0 to $4.0 \mathrm{ppm}$ in 1975, 0.05 to $1.75 \mathrm{ppm}$ in 1976, and from 0.07 to 0.82 in 1977. This is low in comparison to a mean annual (1974) concentration of $1.08 \mathrm{ppm}$ for Birkenes, Norway (Semb 1976). The values reported here are also lower than those found in rain sampled near natural gas processing plants in west central Alberta by Walker (1969). He found most samples contained 0.4 to $1.5 \mathrm{ppm} \mathrm{SO}{ }_{4}{ }^{2-}-\mathrm{S}$. Summers and Hitchon (1973) reported a mean value $0.9 \mathrm{ppm} \mathrm{SO}{ }_{4}{ }^{2-}-\mathrm{S}$ for rain samples in the region of sulphur gas extraction plants in Central Alberta. This value is somewhat higher than that reported by Walker (1969) for the same general area.

The results for the Nipher gauges indicated that there was little deposition of sulphate sulphur in dry particulates, at least east of the Athabasca River. There was less particulate sulphate sulphur than there was sulphate sulphur brought down in rain. The Nipher gauge data is given in this report, but the few data together with more recent and extensive data will be made available through another publication (Nyborg et al. 1977).

4.1.1.3 Cation Content of Rain. The concentration of cations in the 1977 rain samples are shown in Table 10. Rain at field site No. 3 (Supertest Hill) had unusually high concentrations of calcium, magnesium, and potassium. 


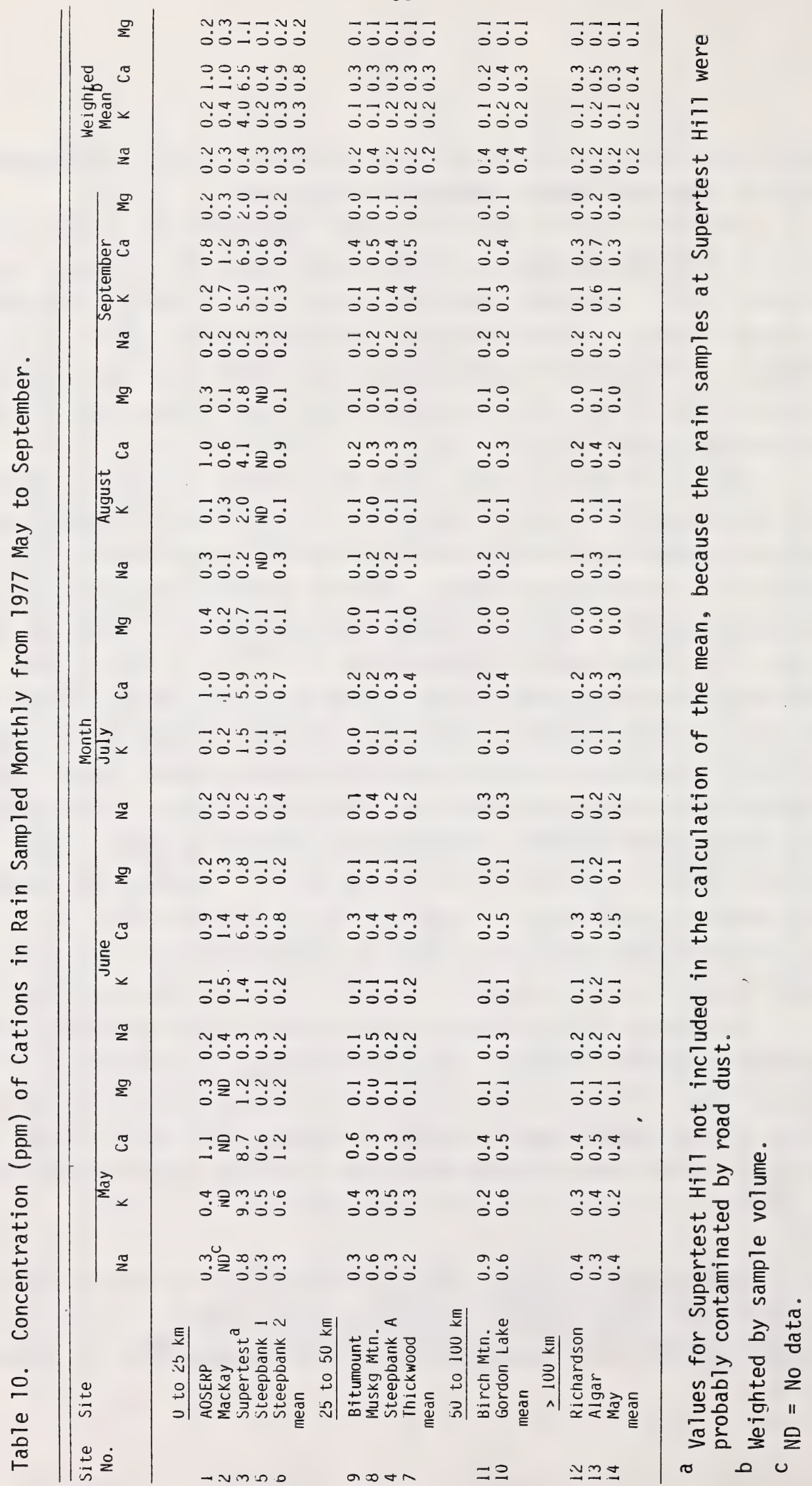


This may be due to contamination by aspen throughfall as mentioned earlier (Section 4.1.1.2).

Barrie and Kovalick (1980) found that during a two-week field study in June 1977, particulate calcium and magnesium content collected at the AOSERP Research Facility, originated mainly from windblown dust sources. This could explain the high calcium content in rain samples collected at field sites Nos. 1 (Mildred Lake) and 2 (MacKay River). Both of these field sites are located within $200 \mathrm{~m}$ of a gravel road.

\subsubsection{Snow}

The $\mathrm{pH}$ of snow sampled in 1976 was not related to the distance from the emission source (Table 11). If all the sulphate sulphur measured in the snow was present as sulphuric acid, and if no other acids were present, then snow having concentrations of 0.16 and $0.51 \mathrm{ppm} \mathrm{SO}_{4}{ }^{2-}$-S would be expected to have $\mathrm{pH}$ values of 5.0 and 4.5 , respectively. However, at all sites snow pH was greater than 5.0 despite $\mathrm{SO}_{4}{ }^{2-}-\mathrm{S}$ concentrations greater than $0.25 \mathrm{ppm}$. This suggests that sulphur in snow was deposited as a neutral salt, or the sulphuric acid was neutralized by alkaline particulates. This is consistent with the cation content of the snow (Table 11). There is essentially a balance between cations and $\mathrm{SO}_{4}{ }^{2-}-\mathrm{S}$ at all sites except at the Mildred Lake where calcium concentration (and $\mathrm{pH}$ ) was high.

Considering that the estimated amounts deposited by snow represent the total deposited between the sampling date and the time snow started to accumulate (about three- and one-half months), the amounts of sulphur deposited in snow $(0.1$ to $0.2 \mathrm{~kg} / \mathrm{ha} /$ month) in the AOSERP study area were $10 \mathrm{w}$.

\subsubsection{Nutrient Cycling Study}

The mean amount of precipitation for each individual sample period was similar for both control and exposed plots (Table 12). Individual rainfall events were sampled on most occassions and dthe range in storm sizes sampled was considerable (Table 12). The measurement period for the exposed black spruce plot was shorter than for the other plots because of difficulty in locating a suitable study area, and with problems setting up the plot collectors (Section 3.1.2). 


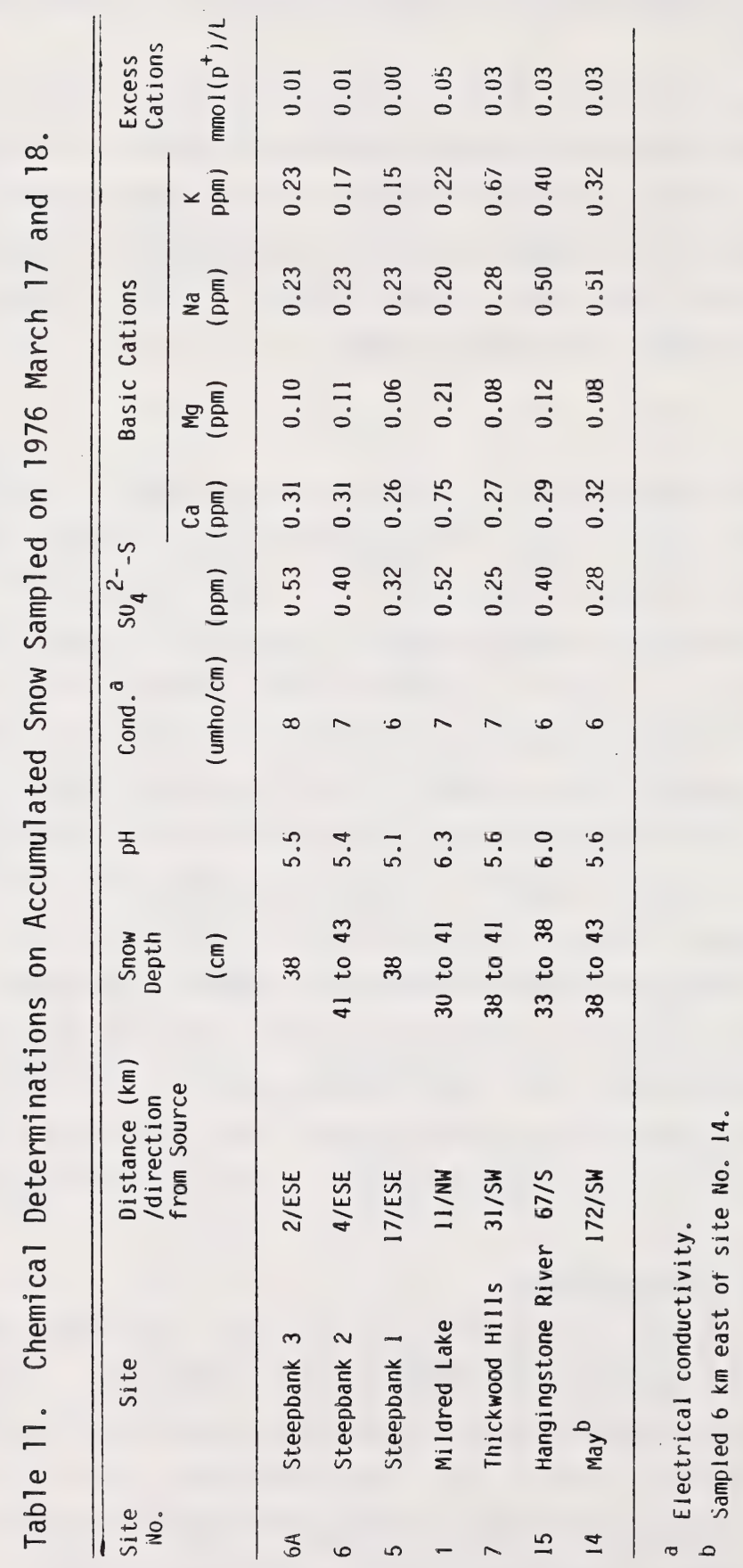




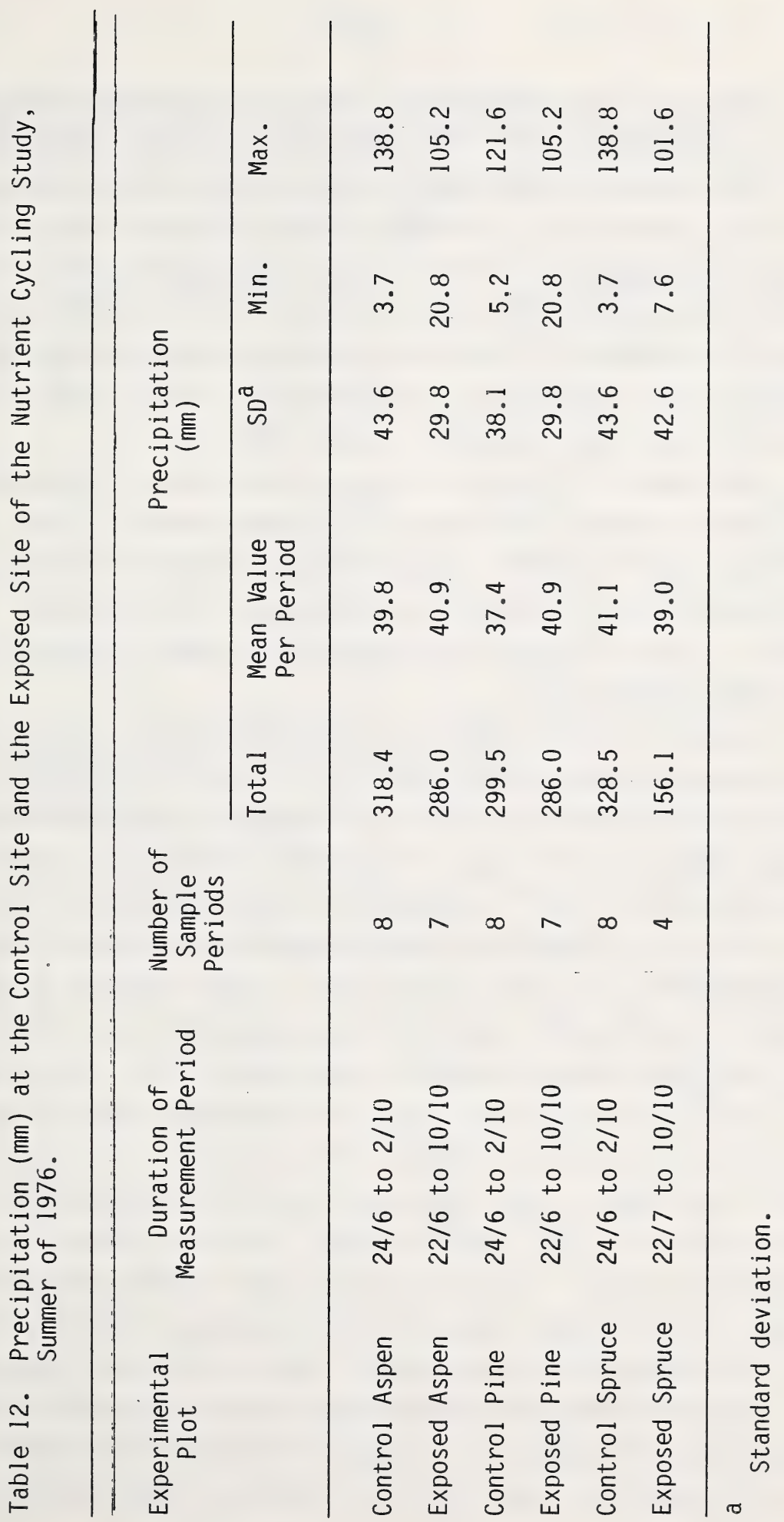


The mean concentrations and $\mathrm{pH}$ or rain for the control and exposed sites are given in Table 13. The mean sulphate sulphur concentration in rain at the exposed site was nearly twice as great as the concentration in rain at the control site. A t-test indicated that the mean volume, nutrient concentrations and mean $\mathrm{pH}$ of rain at the exposed site were not significantly $(p>0.05)$ different from rain at the control site. On the average, rain was not acid at either site. Sulphation discs maintained at each plot showed that the exposed plots received, on the average, more than twice the amount of sulphur emissions than the control plots (Table 14).

The amount of net precipitation (expressed as a percentage of incident rain) reaching the forest floor under trembling aspen, jack pine, and black spruce was $91 \%$ and $85 \%$, respectively. Throughfall averaged about $85 \%$ of incident precipitation for both trembling aspen and jack pine. Stemflow averaged 7 to $8 \%$ of incident precipitation in trembling aspen, and 0.2 to $0.3 \%$ in jack pine (Section 8.3 ).

Assuming that the chemical composition of the rain at each site was on the average the same (except $\mathrm{SO}_{4}{ }^{2-}-\mathrm{S}$ ), it can be seen that there are differences in the nutrient content of throughfall and stemflow between the two sites (Table 15). For aspen throughfal1, there was a greater concentration of $\mathrm{Ca}^{2+} \cdot \mathrm{Mg}^{2+}$, and $\mathrm{SO}_{4}{ }^{2-}-\mathrm{S}$ at the exposed site than the control site. This greater nutrient concentration was associated with a higher throughfall $\mathrm{pH}$ at the exposed site. Aspen stemflow at the exposed site had higher $\mathrm{K}^{+}, \mathrm{Ca}^{2+}, \mathrm{Mg}^{2+}$, and $\mathrm{SO}_{4}{ }^{2-}-\mathrm{S}$ concentrations and higher $\mathrm{pH}$ despite the higher average volume at the exposed site. The concentrations of $\mathrm{K}^{+}, \mathrm{Ca}^{2+}, \mathrm{Mg}^{2+}$, and $\mathrm{SO}_{4}{ }^{2-}-\mathrm{S}$ in jack pine throughfall were higher at the exposed site than at the control site. The $\mathrm{pH}$ of the exposed site throughfall was lower. Jack pine stemflow, like the throughfall, had higher concentrations of $\mathrm{K}^{+}, \mathrm{Ca}^{2+}, \mathrm{Mg}^{2+}$, and $\mathrm{SO}_{4}{ }^{2-}-\mathrm{S}$ at the exposed site than the control site. The $\mathrm{pH}$ of exposed pine stemflow was also markedly lower than for the control site. For black spruce, differences between the control and exposed sites were smaller than for the other two species.

Table 16 shows the weighted mean nutrient concentration and weighted mean $\mathrm{pH}$ for jack pine and aspen throughfall and stemflow for a given sample period when the amount of precipitation at each site was 
Table 13. Mean Nutrient Concentration (ppm) and Mean $\mathrm{pH}$ of Incident Rain in the Summer of 1976 at Plots of Nutrient Cycling Study.a

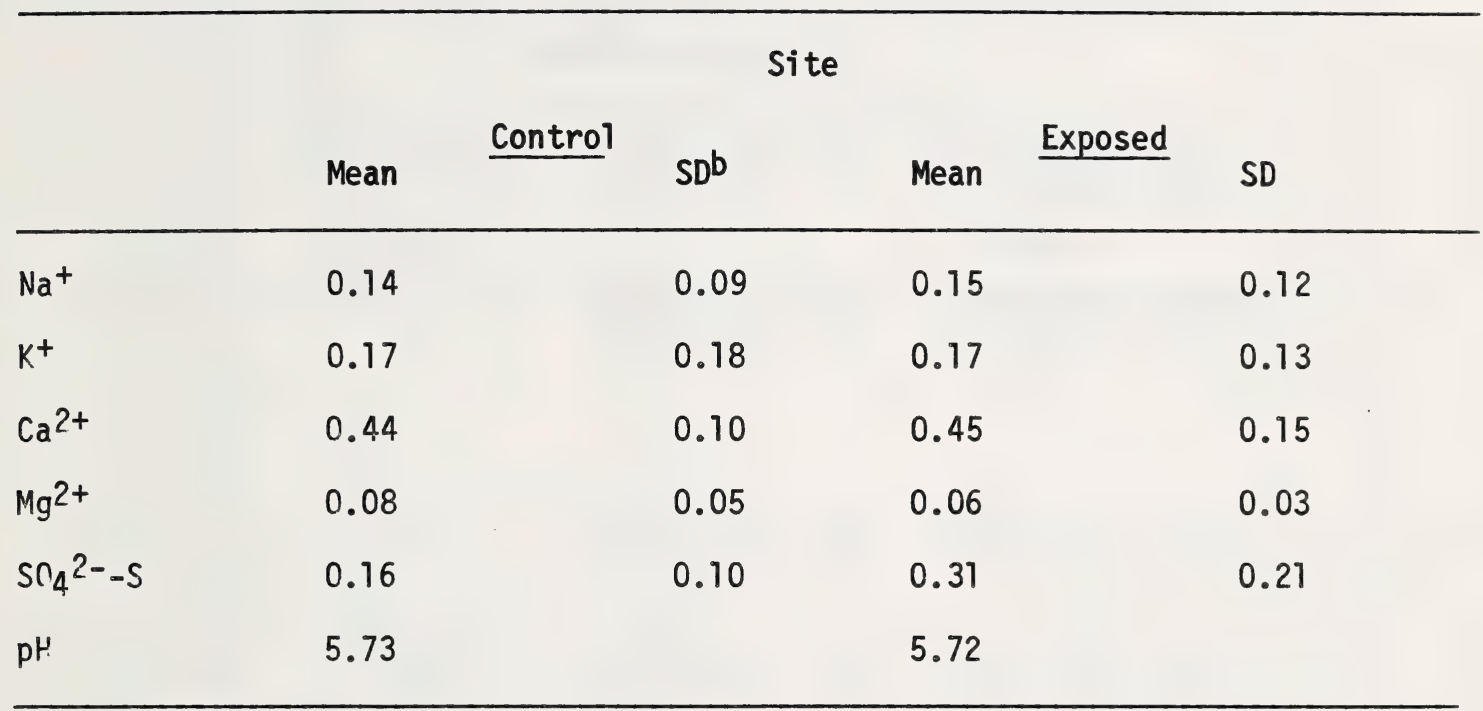

a Geometric means weighted by the sample volumes.

b Standard deviation. 
Table 14. Mean total Sulphation for the Control Site and the Exposed Site of the Nutrient Cycling Study.

$\mathrm{mg} \mathrm{SO} / / 100 \mathrm{~cm}^{2} /$ day

Control Site

0.023
Exposed Site

0.053 


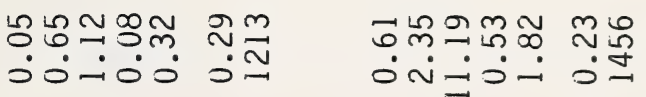

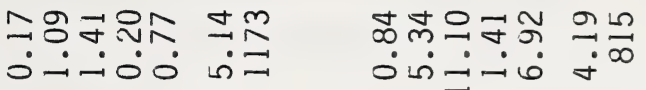

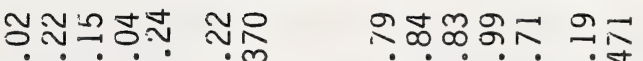
ல0்0ல ப

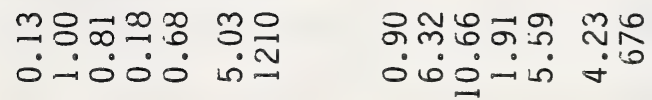

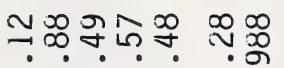

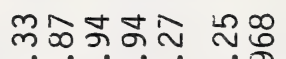
inं $\dot{0} 0$ :

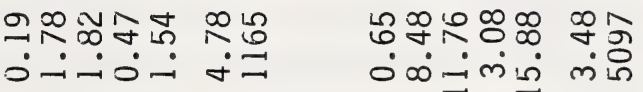

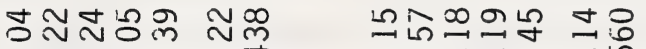
ம்0்ப் ப் ப்ப்ப்

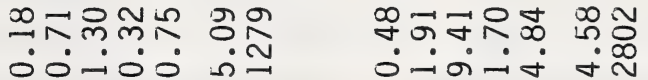

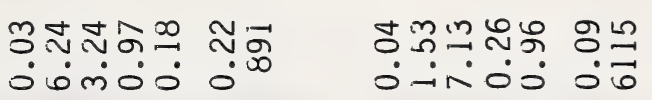

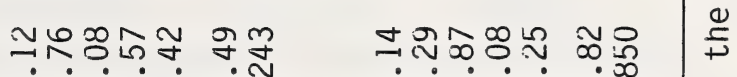

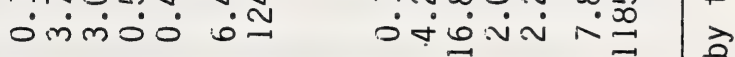

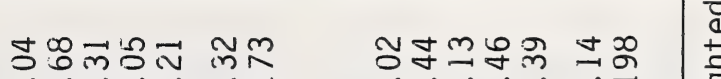
ப்0ல் $\dot{0}$ :

빰드유

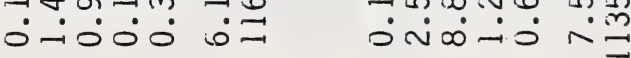

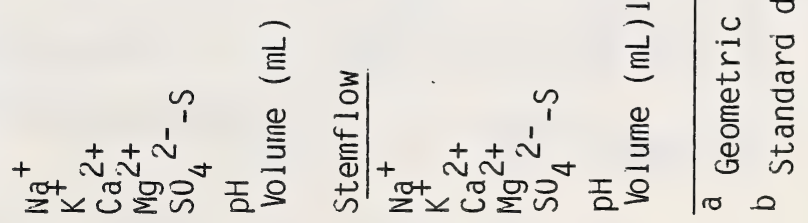


Table 16. Mean Nutrient Concentrations (ppm) and pH of Rain; and of Trembling Aspen and Jack Pine Throughfall and Stemiflow.a

\begin{tabular}{|c|c|c|c|c|}
\hline & \multicolumn{2}{|c|}{ Trembling Aspen } & \multicolumn{2}{|c|}{ Jack Pine } \\
\hline & Controlb & ExposedC & Controld & Exposede \\
\hline Precip. (mm) & 45.0 & 43.0 & 45.4 & 41.6 \\
\hline \multicolumn{5}{|l|}{ Throughfall } \\
\hline $\begin{array}{l}\mathrm{Na}^{+} \\
\mathrm{K}^{+} \\
\mathrm{Ca}^{2+} \\
\mathrm{Mg}^{2+} \\
\mathrm{SC}_{4}{ }^{2-}-\mathrm{S} \\
\mathrm{pH} \\
\text { Volume (mL) }\end{array}$ & $\begin{array}{c}0.19 \\
0.86 \\
0.88 \\
0.13 \\
0.16 \\
6.03 \\
1037\end{array}$ & $\begin{array}{l}0.10 \\
1.03 \\
1.48^{f} \\
0.18^{f} \\
0.49 f \\
6.41 \mathrm{f} \\
1266^{f}\end{array}$ & $\begin{array}{l}0.19 \\
0.99 \\
1.49 \\
0.39 \\
1.09 \\
5.04 \\
1344\end{array}$ & $\begin{array}{l}0.24 \\
2.26^{f} \\
1.77 \\
0.57 \\
1.78 \\
4.72^{f} \\
1055^{f}\end{array}$ \\
\hline \multicolumn{5}{|l|}{ Stemflow } \\
\hline $\begin{array}{l}\mathrm{Na}^{+} \\
\mathrm{K}^{+} \\
\mathrm{Ca}^{2+} \\
\mathrm{Mg}^{2+} \\
\mathrm{SO}_{4}{ }^{2-}-\mathrm{S} \\
\mathrm{pH}^{\text {Volume (mL) }}\end{array}$ & $\begin{array}{r}0.15 \\
2.83 \\
11.69 \\
1.64 \\
0.52 \\
7.56 \\
16025\end{array}$ & $\begin{array}{c}0.19 \\
4.51 \mathrm{f} \\
26.37 \mathrm{f} \\
3.89 f \\
4.21 \mathrm{f} \\
8.03 \mathrm{f} \\
11138\end{array}$ & $\begin{array}{r}0.73 \\
2.82 \\
18.31 \\
2.59 \\
12.87 \\
4.99 \\
1266\end{array}$ & $\begin{array}{c}0.91 \\
11.79 \\
28.76 \\
5.75 f \\
33.00 \mathrm{f} \\
3.50 \mathrm{f} \\
2544\end{array}$ \\
\hline \multicolumn{5}{|l|}{ Rain } \\
\hline $\begin{array}{l}\mathrm{Na}^{+} \\
\mathrm{K}^{+} \\
\mathrm{Ca}^{2+} \\
\mathrm{Mg}^{2+} \\
\mathrm{SO}_{4}{ }^{2-}-\mathrm{S} \\
\mathrm{pH}^{-}\end{array}$ & $\begin{array}{l}0.10 \\
0.07 \\
0.47 \\
0.08 \\
0.08 \\
5.65\end{array}$ & $\begin{array}{l}0.09 \\
0.10 \\
0.49 \\
0.06 \\
0.10 \\
5.03\end{array}$ & $\begin{array}{l}0.09 \\
0.10 \\
0.21 \\
0.02 \\
0.19 \\
5.82\end{array}$ & $\begin{array}{l}0.23 \\
0.21 \\
0.44 \\
0.04 \\
0.60 \\
5.30\end{array}$ \\
\hline
\end{tabular}

a Values are from a single sampling period. The mean value of a given variable $\left(\mathrm{Na}^{+}, \mathrm{K}^{+}\right.$, etc.) at the control site was compared to the corresponding mean value at the exposed site according to Student's t-test. Pairs of values which are significantly different $(p=0.05)$ are indicated by $f$ beside the exposed site values.

b From 28 August to 05 September.

c From 15 July to 29 July.

d From 29 June to 16 July.

e From 30 June to 15 July.

Value for exposed site is statistically different compared to the value for the control site $(p=0.05)$. 
similar. A similar comparison was not possible for black spruce because there was not a sample period when the amount of precipitation for each plot was the same. The concentrations of nutrients at the exposed site were generally higher than at the control site for both species. The differences which are statistically significant $(0=0.5)$ are indicated. Aspen throughfall and stemflow had a higher $\mathrm{pH}$ at the exposed site whereas jack pine throughfall and stemflow were lower in $\mathrm{pH}$ at the exposed site.

The total amounts of nutrients returned to the soil in incident rain, throughfall and stemflow for jack pine and trembling aspen at both sites are given in Section 8.4 .

Since nutrient quantities in dry fallout were not determined separately, these quantities are included in the amounts of nutrients recorded in the throughfall and stemflow. A number of researchers have recognized the possibility that aerosols and dust may adhere to leaves, branches, and stems and then add significantly to the chemical composition of throughfall and stemflow (Eriksson 1958, Tamm and Troedsson 1955, Hart and Parent 1974, and Nihlgard 1970). In this study, particulate deposition from the emissions source could be an important component of the nutrient content of throughfall and stemflow at the exposed site, particularly for sulphate sulphur. This component represents the filtering action of the forest canopy on airborne particulates and aerosols. A detailed discussion of these results is given by Parker (1978).

\subsubsection{Deposition of Sulphate Sulphur in Aspen Throughfall and Stemflow.}

The average $\mathrm{pH}$ and sulphate sulphur concentrations in throughfall and stemflow of different tree species at the various field sites are shown in Section 8.5. These samples were collected every two weeks from nine throughfall collections and three stemflow collections at each site during the summer of 1975 and 1976.

The deposition of $\mathrm{SO}_{4}{ }^{2-}-\mathrm{S}$ in trembling aspen throughfall and stemflow measured in 1976 at the nutrient cycling study plots is given in Table 17. At both the control site and the exposed site the amount of sulphur deposited in throughfall and stemflow was higher than that deposited in incident rain. The amount deposited in both the incident rain and the 


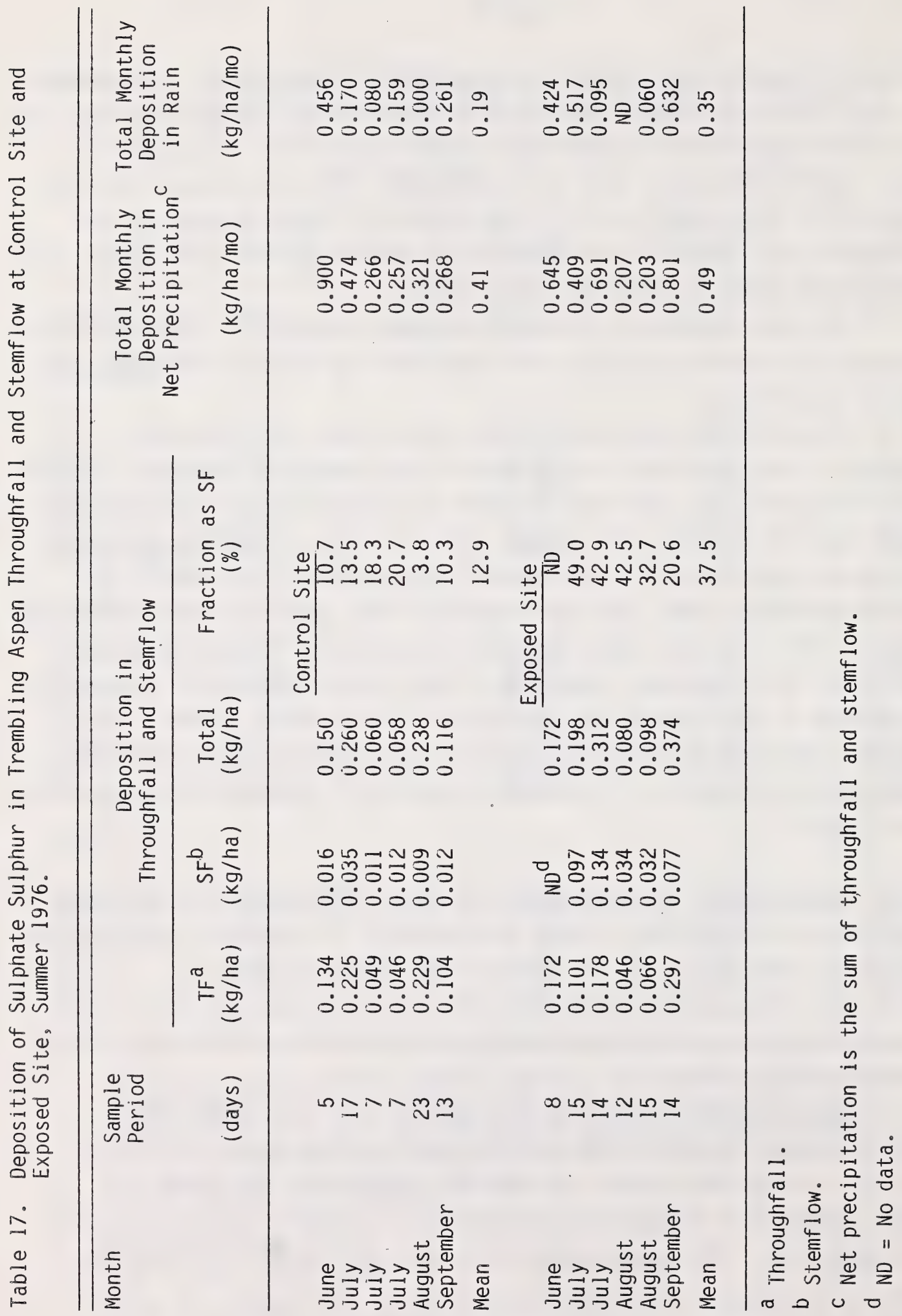


throughfall and stemflow was greater at the site exposed to sulphur dioxide than at the control site. The deposition expressed as $\mathrm{kg} / \mathrm{ha} / \mathrm{month}$ was calculated from the deposition in $\mathrm{kg} / \mathrm{ha}$ at each sample period by weighting each value by the number of days in the month divided by the number of days over which the sampled was collected. This method assumes that the precipitation over the sample period represents the mean precipitation/day over the month. This may not be the case particularly where only one sample per month was obtained. This method allows comparison with other forms of sulphur dioxide.

The fraction of precipitation returned to the soil (throughfall plus stemflow) as stemflow was $7 \%$ and $8 \%$ at the control aspen plot and exposed aspen plot, respectively (Section 8.3 ). The fraction of sulphate sulphur deposited as stemflow was much greater at the exposed plot $(38 \%)$ than at the control plot $(13 \%)$. The difference in the amount of the sulphate sulphur deposited in stemflow must therefore reflect the influence of atmospheric sulphur on aspen trees at the exposed site. When the amount of sulphate sulphur deposited in incident rain, throughfall, and stemflow at each site is weighted by the amounts of each particular precipitation fraction at each site (in $\mathrm{mm}$ ), a direct comparison between sites is possible. Such a calculation reveals that, if equivalent amounts of precipitation occurred at each site, an estimated $53 \%$ more sulphate sulphur would be removed from the tree canopy (throughfall plus stemflow minus incident rain) at the exposed site compared to the control site. Values for this calculation were taken from the tables in Sections 8.3 and 8.4, and detailed steps to the method of calculation are given in Section 8.4 .

\subsubsection{Deposition of Sulphur in Jack Pine Throughfall and Stemflow. The} deposition of sulphate sulphur in jack pine throughfall and stemflow are shown in Table 18. As for trembling aspen, there were greater quantities of $\mathrm{SO}_{4}{ }^{2-}$-S deposited in the throughfall and stemflow than in incident rain. Amounts of $\mathrm{SO}_{4}{ }^{2-}-\mathrm{S}$ deposited under jack pine were al so greater than amounts deposited under aspen at both the control and exposed sites.

The fraction of precipitation returned to the soil (throughfall plus stemflow) as stemflow was on the average less than $1 \%$ for both the control and 


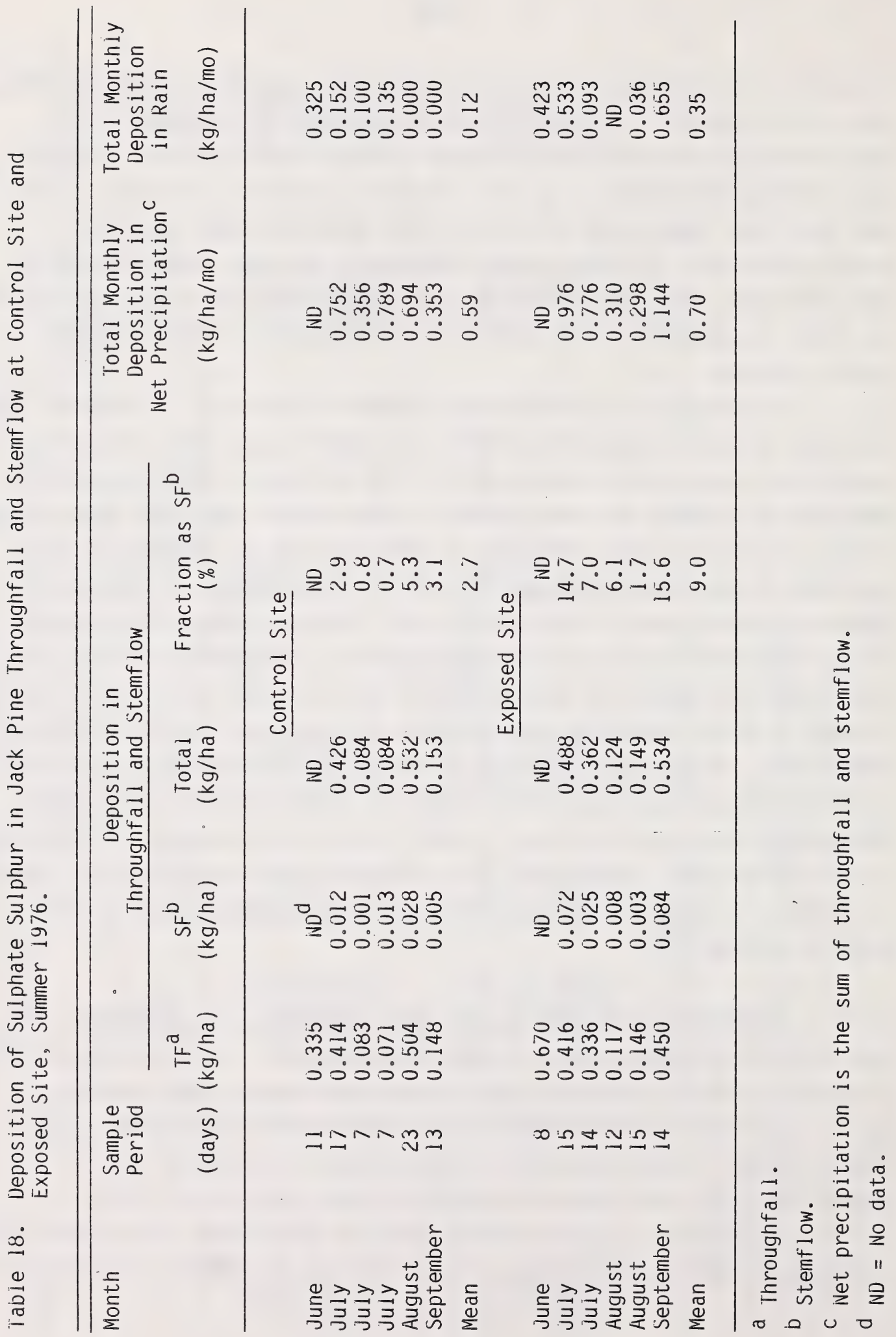


exposed jack pine plots (Section 8.3). The corresponding fractions of $\mathrm{SO}_{4}{ }^{2-}$-S deposited in stemflow was $3 \%$ for the control plot and $9.0 \%$ for the exposed plot (Table 18). As for trembling aspen, the larger proportion of $\mathrm{SO}_{4}{ }^{2-}-\mathrm{S}$ deposited in stemflow at the exposed plot apparently represents removal of anthropogenic sulphur from the tree stems.

\subsubsection{Effect of Sulphur Dioxide on Jack Pine Stemflow Chemistry. Jack pine stemflow sampled during June and July 1977 was} progressively less acidic and contained lower levels of sulphate sulphur with increasing distance from the emission source (Table 19). The low concentrations of $\mathrm{SO}_{4}{ }^{2-}-\mathrm{S}$ at the Muskeg Mountain site (exposed) could be due to the higher stemflow volume and similarly the higher $\mathrm{SO}_{4}{ }^{2-}-\mathrm{S}$ concentration at Algar (control) could be due to the low stemflow volumes recorded. When these concentration values were converted to sulphate sulphur deposition as $\mathrm{kg} / \mathrm{ha} /$ month, they were multiplied by the respective stemflow volumes and the number of stems/ha. These values show the general decrease with increasing distance from the emission source. Ths is coincident with a decrease in the average $\mathrm{SC}_{2}$ concentrations in the air at each site as determined by the total sulphation discs.

The difference in $\mathrm{pH}$, titratable acidity, sulphate sulphur and total sulphation were significant $(p=0.05)$ between sites (Table 20). The trends in stemflow acidity and sulphate sulphur content as illustrated in Figure 8. This figure includes data from a remote site in Canwood, Saskatchewan.

The $\mathrm{SO}_{4}{ }^{2-}$-S concentrations and free acid concentrations in jack pine stemflow are highly correlated at sites close to the emission source and are not correlated at the remote sites (Table 21 ). A similar relationship was found for jack pine throughfall in the nutrient cycling study (Section 4.1.3). The hydrogen ion concentration was highly correlated with $\mathrm{SO}_{4}{ }^{2-}$-S concentrations at the exposed plot $\left(r^{2}=0.86\right)$ and poorly correlated with $\mathrm{SO}_{4}{ }^{2-}$-S concentrations at the control site $\left(r^{2}=0.12\right)$. These results show that there was a greater deposition of sulphuric acid beneath jack pine at sites close to the emissions source as compared to the more remote sites. 


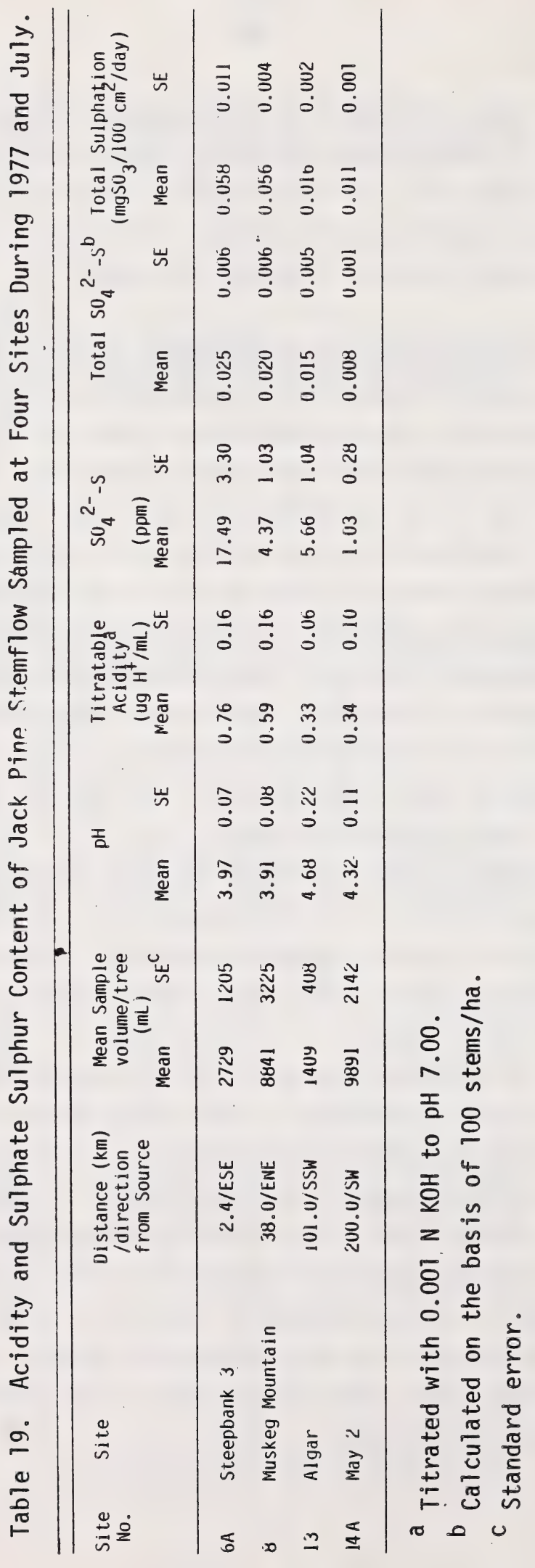


Table 20. Analysis of Variance Between Sites.

\begin{tabular}{lcccc}
\hline & $\mathrm{pH}$ & $\begin{array}{c}\text { Titratable } \\
\text { Acidity }\end{array}$ & $\mathrm{SO}_{4}{ }^{2-}-\mathrm{S}$ & $\begin{array}{c}\text { Total } \\
\text { Sulphation }\end{array}$ \\
\hline $\mathrm{df}$ & 53 & 53 & 53 & 54 \\
$\mathrm{~F}$ ratio & 6.716 & 2.903 & 14.572 & 27.204 \\
F probability & $\mathrm{b}$ & $\mathrm{a}$ & $\mathrm{b}$ & $\mathrm{b}$ \\
\hline
\end{tabular}

a signficant at $p>0.05$.

b significant at $p>0.001$. 


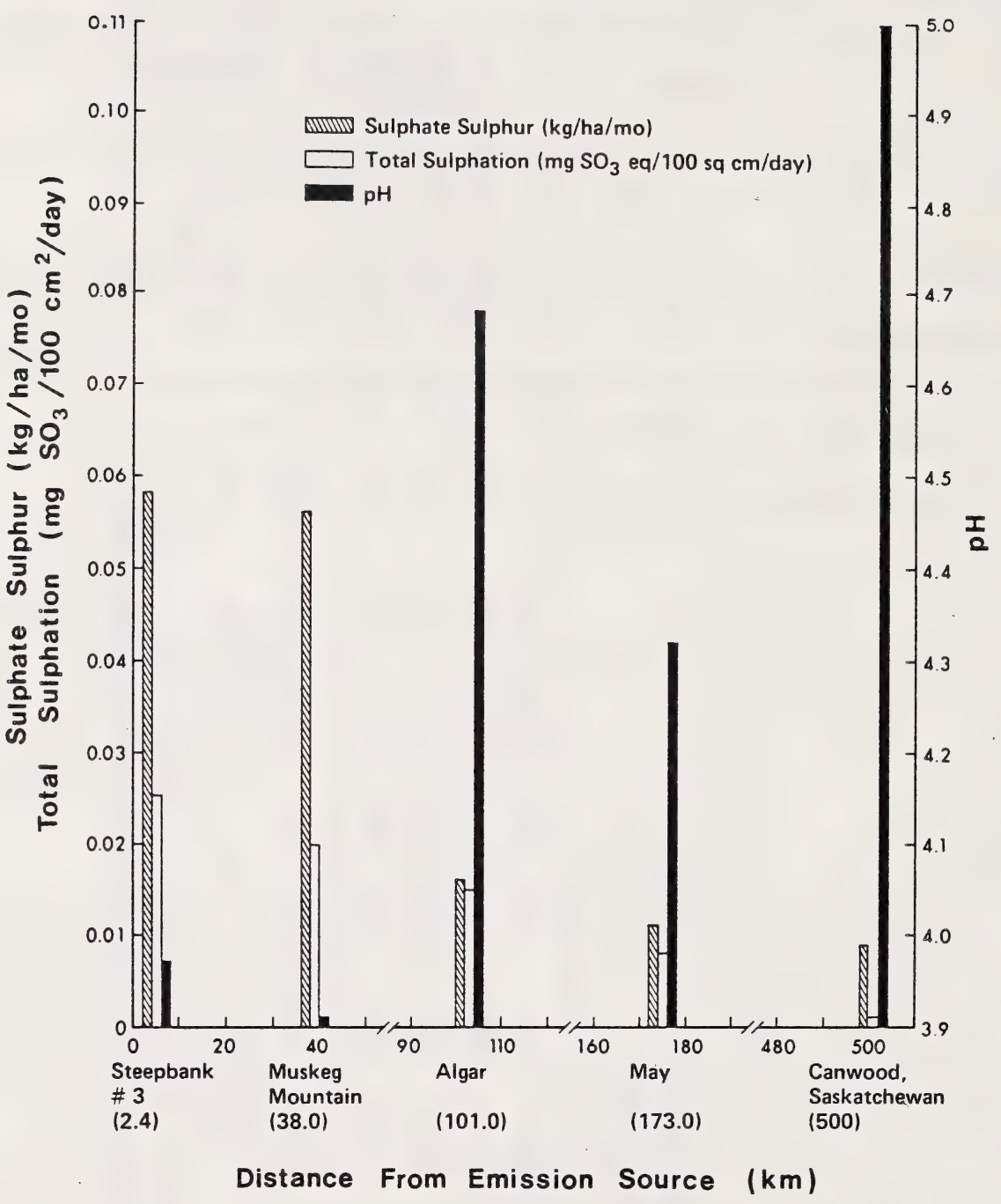

Fiaure 8. The Variation in Sulphate Sulphur and Acidity of Jack Pine ( $P$. banksiana Lamb.) Stemflow with Increasina Distance from a Sulphur Dioxide Emission Source. 
Table 21. Relationship of Acidity and Sulphate Sulphur Content of Jack Pine Stemflow Sampled at Four Sites During June and July 1977.

\begin{tabular}{|c|c|c|c|c|c|}
\hline \multirow{2}{*}{$\begin{array}{l}\text { Site } \\
\text { No. }\end{array}$} & \multirow[t]{2}{*}{ Site } & \multirow{2}{*}{$\begin{array}{l}\text { Distance } \\
\text { Direction } \\
\text { from Source } \\
(\mathrm{km})\end{array}$} & \multicolumn{3}{|c|}{$\begin{array}{l}\text { Correlation of Hydrogen } \\
\text { Ion Concentration versus } \\
\mathrm{SO}_{4}{ }^{2--S} \text { Contenta }\end{array}$} \\
\hline & & & $\begin{array}{l}\text { Correlation } \\
\text { Coefficient } \\
(r)\end{array}$ & $r^{2}$ & $\begin{array}{c}\text { Significance } \\
\text { level }\end{array}$ \\
\hline $6 A$ & Steepbank 3 & $2.4 / E S E$ & 0.80 & 0.64 & 0.001 \\
\hline 8 & Muskeg Mountain & $38.0 /$ ENE & 0.76 & 0.58 & 0.01 \\
\hline 13 & Algar & $101.0 / S S W$ & 0.23 & 0.05 & 0.22 \\
\hline $14 \mathrm{~A}$ & May 2 & $200.0 / \mathrm{SW}$ & -0.12 & 0.01 & 0.34 \\
\hline
\end{tabular}

a. Calculated from the $\mathrm{pH}$ (hydrogen ion concentration $=10^{-} \mathrm{pH}$ ). 


\subsubsection{Impact of Sulphur Dioxide on Bark Leachate Acidity and Sulphur} Content

To further investigate the field findings, bark samples from jack pine, trembling aspen, and black spruce were exposed to sulphur dioxide in a controlled atmosphere experiment. The results (Table 22) show that jack pine bark leachate was more acid and contained higher amounts of $\mathrm{SO}_{4}{ }^{2-}-\mathrm{S}$ after exposure to sulphur dioxide. The $\mathrm{pH}$ of jack pine bark leachate decreased from about 5.5 to 4.8 , a change of $0.7 \mathrm{pH}$ units. This decrease in $\mathrm{pH}$ was associated with a large increase in the $\mathrm{SO}_{4}{ }^{2-}-\mathrm{S}$ concentration. For the jack pine bark samples from Algar, the hydrogen ion concentration (as calculated from the $\mathrm{pH}$ values) increased $279 \%$ while the $\mathrm{SO}_{4}{ }^{2-}-\mathrm{S}$ concentration increased by $405 \%$ upon exposure to $\mathrm{SO}_{2}$. Spruce bark showed a similar trend as for jack pine but the changes were not as large.

The reduction in $\mathrm{pH}$ of the aspen bark leachate is contrary to the field results where aspen stemflow increased in $\mathrm{pH}$ at the site exposed to sulphur dioxide (Table 15). However, the increased sulphate sulphur concentration of the exposed bark leachate is consistent with the increased $\mathrm{SC}_{4}{ }^{2-}$-S concentration of aspen stemflow at the exposed site (Table 15). The difference in the laboratory findings with respect to $\mathrm{pH}$ may be because aspen stemflow consists of rainwater which has been intercepted by the foliage and then runs down the branches and down the stem. The smooth bark of aspen and the acutely angled branches cause a channelling of water down the tree trunk. This could alter the composition of any bark leachate and is responsible for the high stemflow volume found in aspen. Thomas (1969) sampled stemflow on dogwood which had been tagged with ${ }^{45} \mathrm{Ca}$ and found that after leaf abscission, stemflow contained ${ }^{45} \mathrm{Ca}$ at much lower concentrations than when trees supported foliage, indicating that direct leaching from the bark did not contribute as much to the chemical composition of the stemflow as did leaching of the leaves. However, the laboratory experiments here indicate that a substantial amount of the stemflow $\mathrm{SO}_{4}{ }^{2-}-\mathrm{S}$ content would be derived from leaching of bark. 
Table 22. $\mathrm{pH}$ and $\mathrm{SO}_{4}{ }^{2-}-\mathrm{S}$ Content of Bark Washings Exposed to $\mathrm{SO}_{2}$ in a Controlled Environment Chamber for Seven Days.a

\begin{tabular}{lllll}
\hline \multicolumn{1}{c}{ Samplec } & $\mathrm{pH}$ & $\begin{array}{c}\text { Change } \\
\text { in pH }\end{array}$ & $\begin{array}{c}\mathrm{SO}_{4}^{2-} \mathrm{s}^{\mathrm{b}} \\
(\mathrm{ppm})\end{array}$ & $\begin{array}{c}\text { Area } \\
\left(\mathrm{cm}^{2}\right)\end{array}$ \\
\hline Exposed Aspen & 5.53 & -0.34 & 1.97 & 56.3 \\
Control Aspen & 5.87 & & 0.29 & 56.3 \\
Exposed Spruce & 4.75 & & 1.43 & 56.3 \\
Control Spruce & 5.06 & -0.31 & 0.30 & 56.3 \\
Exposed Pine (May) & 4.87 & & $0.56(0.70)$ & 30.0 \\
Control Pine (May) & 5.64 & -0.77 & 0.23 & 37.5 \\
Exposed Pine (A1 gar) & 4.81 & & $1.87(0.83)$ & 25.0 \\
Control Pine (Algar) & 5.49 & -0.68 & 0.37 & 56.3 \\
\hline
\end{tabular}

a Average $\mathrm{SO}_{2}$ concentration $=0.1 \mathrm{ppm}$.

Average humidity concentration $=80 \%$.

Average air temperature $=22^{\circ} \mathrm{C}$.

b $\mathrm{SO}_{4}{ }^{2-}-\mathrm{S}$ concentration weighted according to bark sample area with control bark sample area considered equal to one. Actual concentration value is given in brackets.

c Site where bark was sampled is given in brackets. 


\subsubsection{Summary - Wet Deposition}

The amount of sulphur deposition in rain in the AOSERP study area was low. In 1976 and 1977 at sites close to the emission source, the amount of $\mathrm{SO}_{4}{ }^{2-}$-S deposited averaged 0.3 to $0.6 \mathrm{~kg} / \mathrm{ha} / \mathrm{month}$ while at remote sites than $0.25 \mathrm{~kg} / \mathrm{ha} /$ month was deposited. Deposition of $\mathrm{SO}_{4}{ }^{2-}-\mathrm{S}$ in snow was also very low with about $0.15 \mathrm{~kg} / \mathrm{ha} / \mathrm{month}$ being deposited at sites close to the emission source compared to less than $0.10 \mathrm{~kg} / \mathrm{ha} / \mathrm{month}$ at more distance sites in 1976.

Greater quantities of $\mathrm{SO}_{4}{ }^{2-}$-S were deposited in throughfall and stemflow than in rain. There was also increased deposition of $\mathrm{SO}_{4}{ }^{2-}-\mathrm{S}$ in throughfall and stemflow at exposed sites compared to remote sites. In 1976, approximately 0.5 to $4.7 \mathrm{~kg} / \mathrm{ha} /$ month was deposited in throughfall and stemflow at exposed sites compared 0.4 to $0.6 \mathrm{~kg} / \mathrm{ha} / \mathrm{month}$ at control sites, depending on the tree species.

The acidity of rain decreased as it passed through the canopy of trembling aspen whereas rainfall acidity increased as it passed through the canopy of jack pine. The acidity of jack pine throughfall and stemflow increased at sites exposed to sulphur dioxide compared to control sites. Throughfall decreased in $\mathrm{pH}$ by about $0.3 \mathrm{pH}$ units and stemflow decreased by about 0.8 to $1.1 \mathrm{pH}$ units.

For both jack pine and trembling aspen, larger quantities of the cations $\mathrm{K}^{+}, \mathrm{Ca}^{2+}$, and $\mathrm{Mg}^{2+}$ were removed from the canopy at the site closer to the emission source compared to the remote site.

Further research is needed into the mechanism of the influence of $\mathrm{SO}_{2}$ on nutrient cycling. These results pose the question as to what effects these differences between species have on forest ecosystems in the AOSERP study area. In particular, how do changes in the chemistry of throughfall and stemflow affect nutrient cycling and soil properties? The nutrients in throughfall and stemflow become part of the available nutrient pool in the soil (Figure 9). Is the increased input in throughfall and stemflow the result of leaching of nutrients from the tree canopy? Is there an increase in plant nutrient uptake to compensate for this or are these nutrients lost by leaching from the soil? 


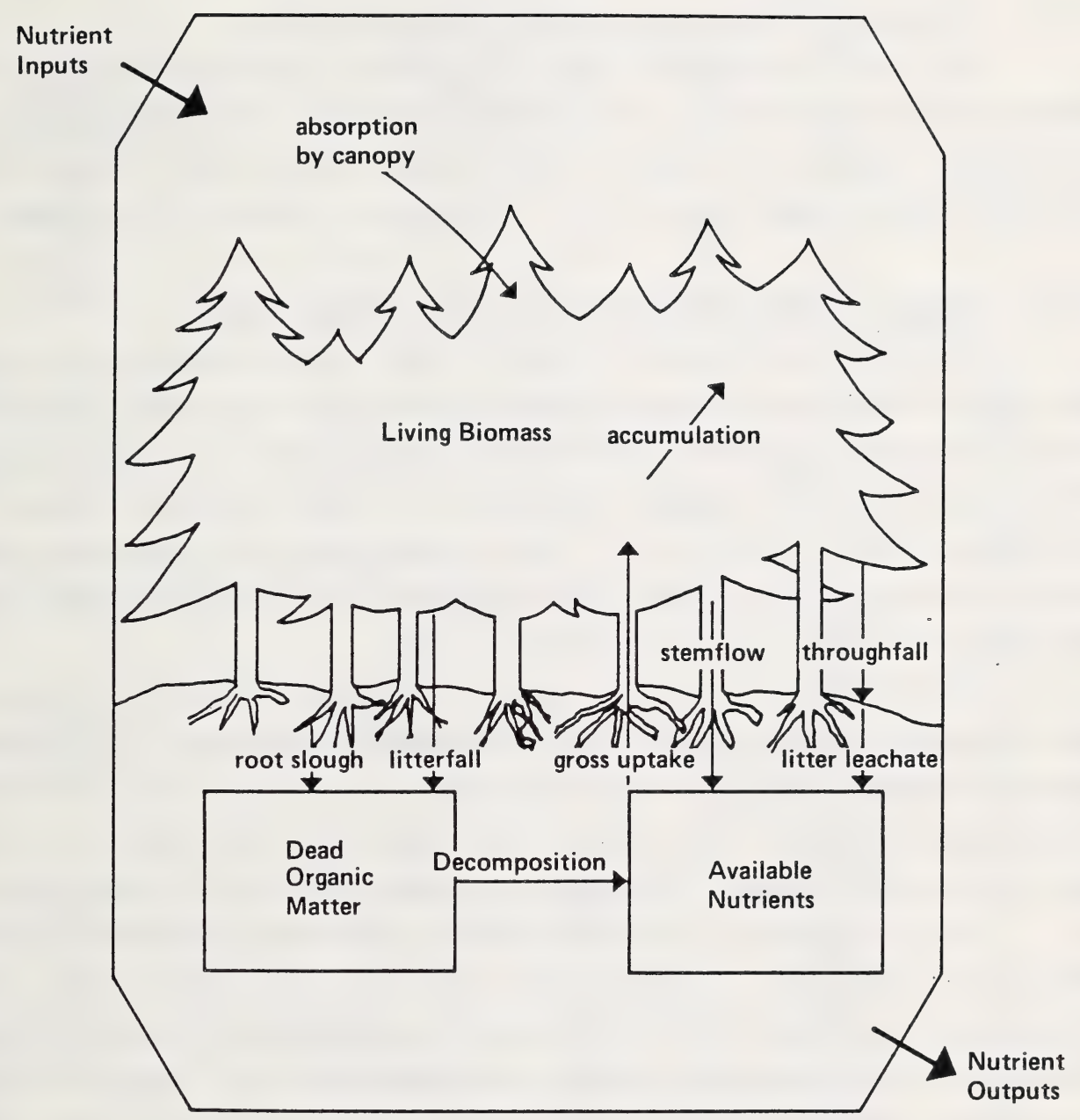

Figure 9. Components of the Nutrient Cycle for a Forest Ecosystem Showed Sites of Nutrients Accumulation and Major Pathways. (After Eaton et a1. 1973) 


\subsection{DRY DEPOSITION}

\subsubsection{Sulphur Dioxide Absorption by Sulphation Discs.}

The total sulphation values of sulphation discs set out over the summers of 1976 and 1977 are given in Section 8.6. The network of sulphation discs became part of an extended network maintained by the Pollution Control Division, Alberta Department of the Environment in June 1974 (Strosher 1978).

\subsubsection{Sulphur Uptake by Bare Soils - Field Experiments}

The average $\mathrm{pH}$ values of several soils exposed under rain shelters from June to September 1975 are given in Table 23. All of the soils within $30 \mathrm{~km}$ of the emission source increased in acidity over the summer compared to soils located at remote sites. The moist soils had a greater increase in acidity than the soils kept dry. This is consistent with the observation of Terraglio and Manganelli (1966) that increased soil moisture content increases the amount ot sulphur dioxide absorbed by soil.

The $\mathrm{pH}$ of the 0 to $1 \mathrm{~cm}$ layer of the sandy 0 . EB soil set out at 13 field sites during the summer of 1976 is shown in Figure 10. After being exposed to sulphur emissions for a period of four months, the $\mathrm{pH}$ of soils located within $50 \mathrm{~km}$ of the emission source was lower by about $0.2 \mathrm{pH}$ units than that of soils located at greater distances from the emission source.

It is important to note that short-term field experiments on the effect of $\mathrm{SO}_{2}$ emissions on soil $\mathrm{pH}$ must take into consideration the natural fluctuation in $\mathrm{pH}$ from site to site which may mask changes caused by $\mathrm{SO}_{2}$. Differences in soil moisture content and temperature will result in changes in the rates of ammonification and nitrification of soil nitrogen which will alter the soil $\mathrm{pH}$. This effect is greatest in bare soils where ammonium or nitrates accumulate instead of being taken up by plants. In our field experiments, the moisture contents of the soils were kept as uniform as possible by watering the soils to field capacity every week in 1975 and every two weeks in 1976.

The amounts of sulphur absorbed (as indicated by $\mathrm{SO}_{4}{ }^{2-}-\mathrm{S}$ analyses) by the top $1 \mathrm{~cm}$ of the sandy O.EB soil and the TY.M soil set under rain shelters at 13 field sites is shown in Figures 11 and 12 . The 


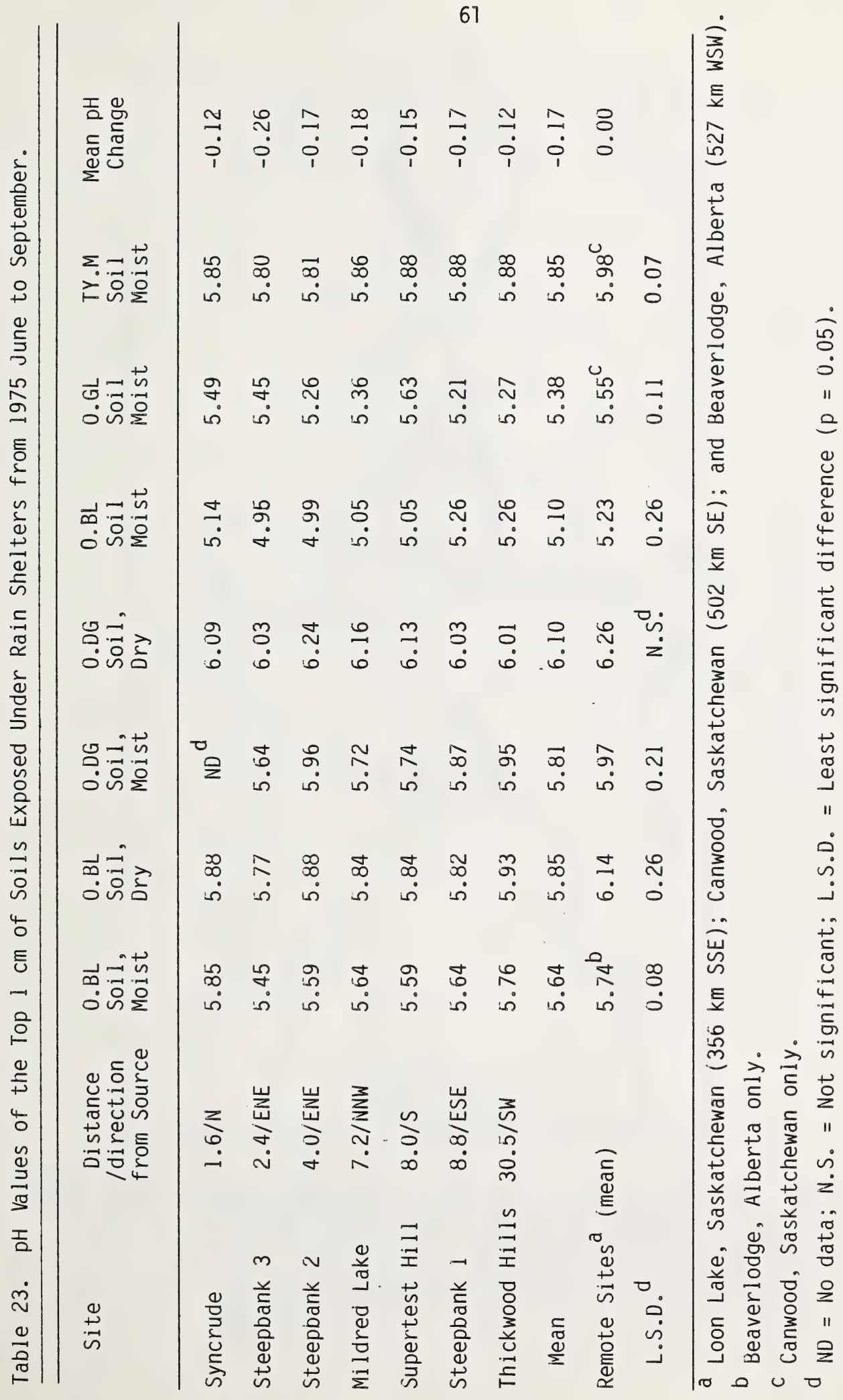




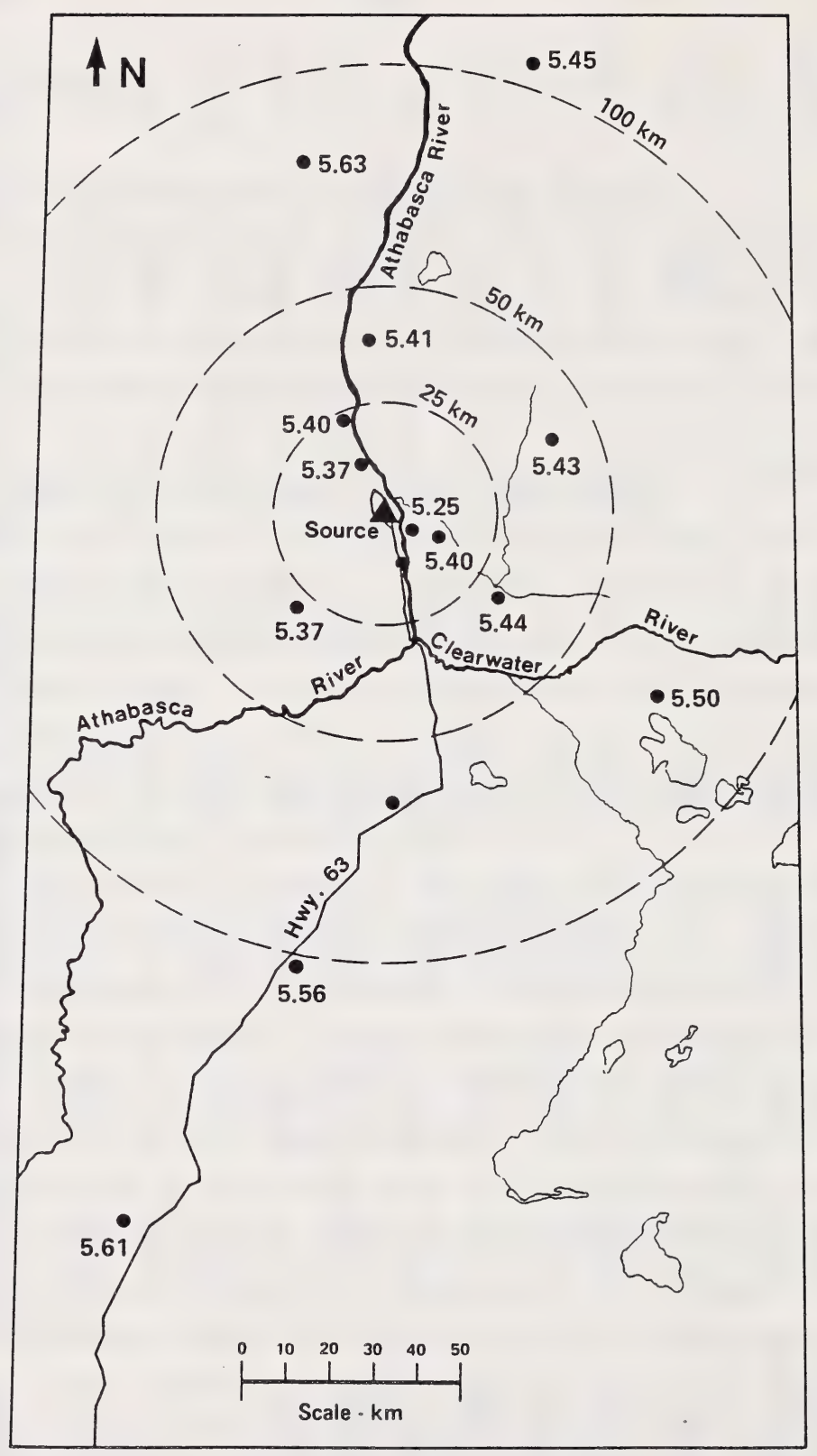

Fiaure 10. $\mathrm{pH}$ Values of $1 \mathrm{~cm}$ Top of the Sandy 0.EB Soil Kept Under Rain Shelters from 1976 June to September. 


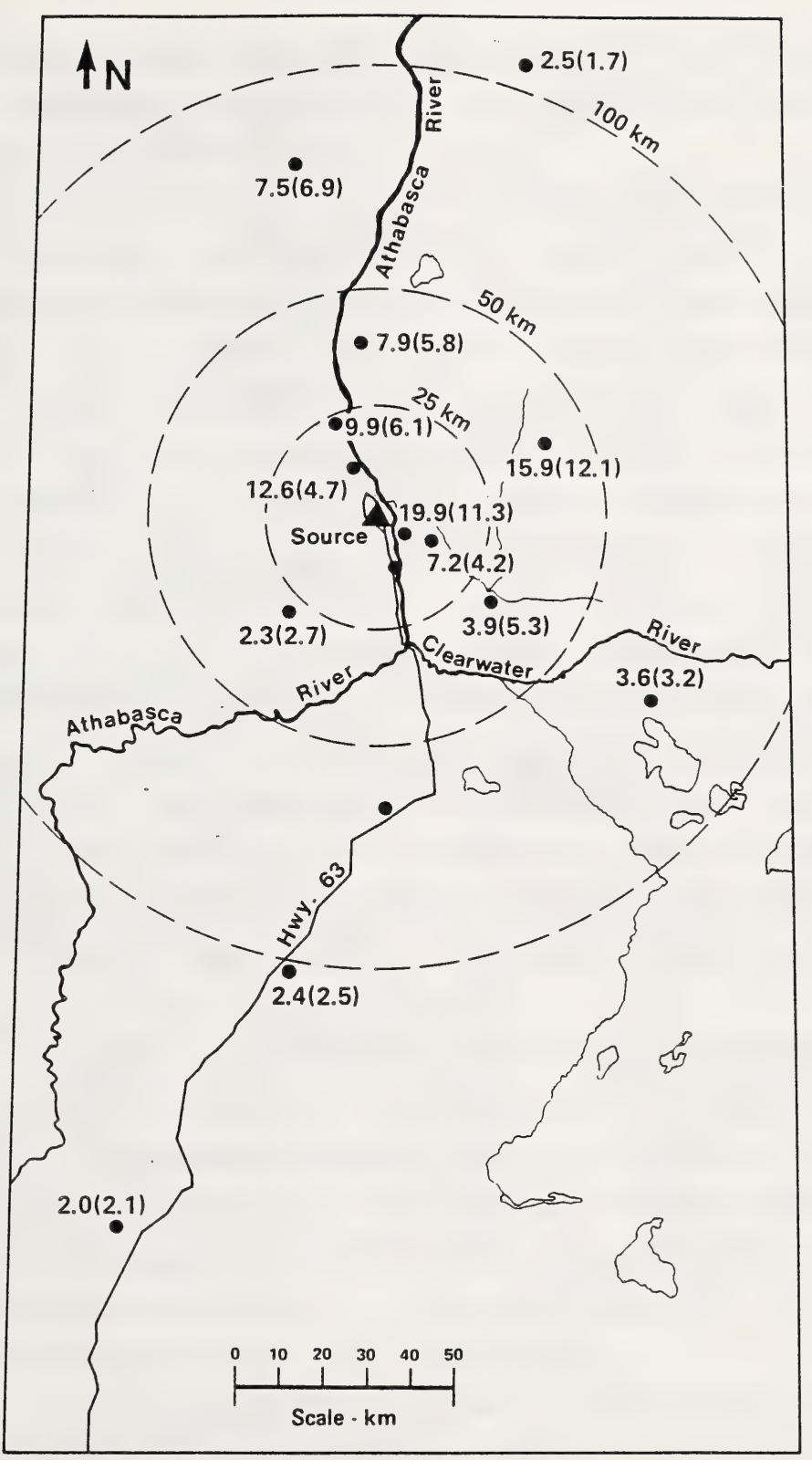

Fiqure 11. Sulphur (ug $/ \mathrm{cm}^{2} / \mathrm{mo}$ ) Adsorbed by Sulphation Discs from 1976 June 01 to September 30, and in Brackets the Sulphate Sulphur (ppm) Content of the Surface of $1 \mathrm{~cm}$ of the Sandy O.EB Soil Set Out for the Same Period. 


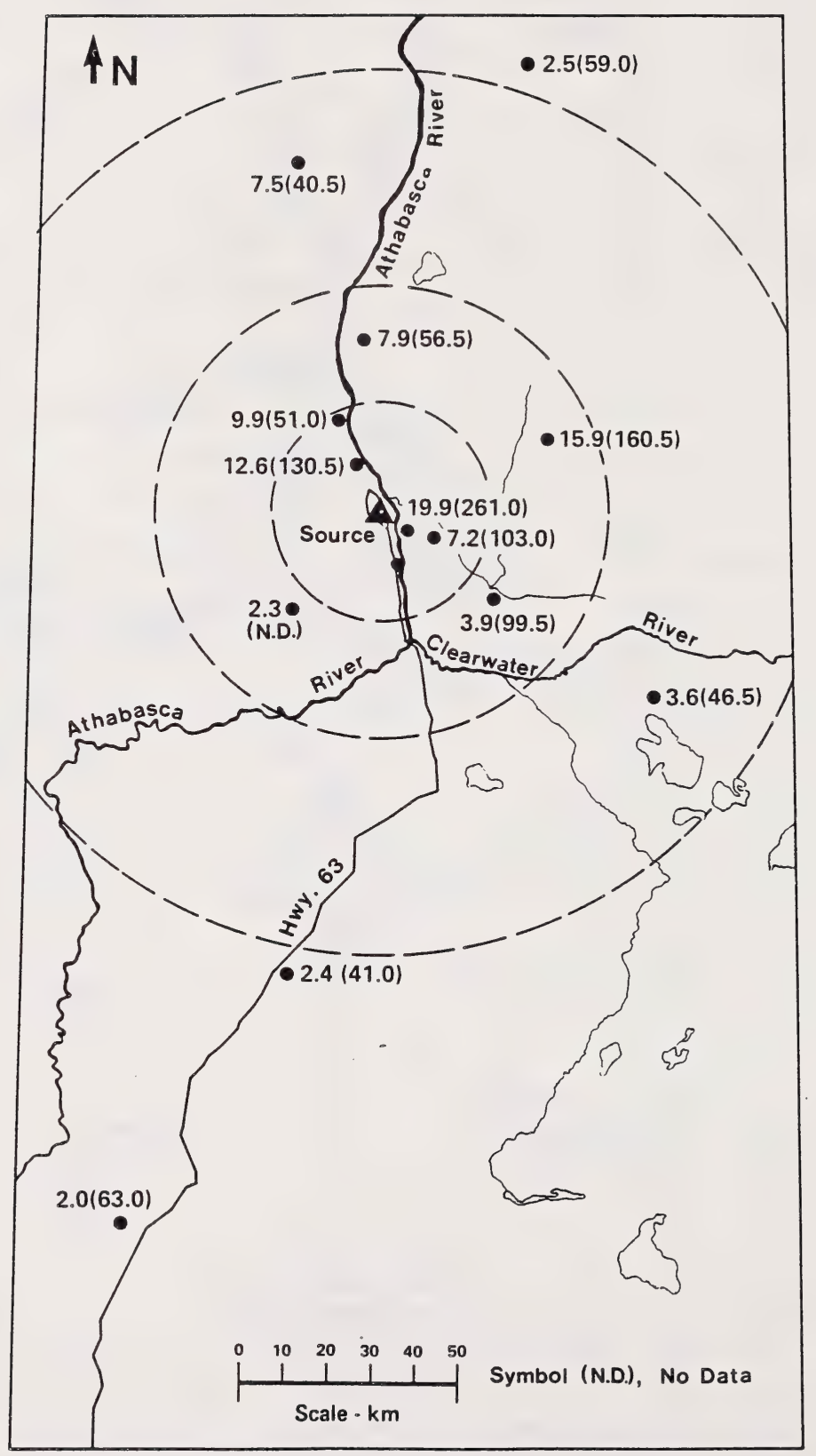

Figure 12. Sulphate Sulphur (ug/ $\mathrm{cm}^{2} / \mathrm{mo}$ ) Absorbed by Sulphation Discs from 1976 June to September, and in Brackets the Sulphate Sulphur (ppm) Content of the Surface of $1 \mathrm{~cm}$ of the TY.M Soil Set Out for the Same Period. 
$\mathrm{SO}_{4}{ }^{2-}$-S concentrations in the sandy $\mathrm{O}$.EB soil and the TY.M soil were signficantly $(p=0.001)$ correlated with the total sulphation values at each site $\left(r^{2}=0.79\right.$ and 0.80 , respectively).

Table 24 shows the final $\mathrm{pH}$ values of the two soils after being set out at nine field sites over the summer of 1976. The main source of sulphur for these soils was from gaseous emissions since the soils were kept under the rain shelters. The surface layer $(0$ to $1 \mathrm{~cm})$ of both the peat and pine sand became more acid than the layer beneath $(1$ to $3 \mathrm{~cm})$ at all sites. The $\mathrm{pH}$ of the surface layer of both soils was depressed in those soils nearest the emission source. The 0 to $1 \mathrm{~cm}$ layer of pine sand had decreased in pH by 0.34 units at the site nearest the emission source (Steepbank 2) as compared to the corresponding layer of pine sand located at the site furthest from the emission source (May). The 0 to $1 \mathrm{~cm}$ layer of peat at Steepbank 2 had a decrease in $\mathrm{pH}$ of 0.15 units compared to a corresponding layer of peat at May. These differences in $\mathrm{pH}$ for a given soil and depth were significant $(p=0.05)$ between sites. The depression in $\mathrm{pH}$ over the summer period may be smal1, but the trends are clear--soil pH is depressed nearer the emission source. Other researchers have shown similar results in both field (Johansson 1959, Cox 1975) and laboratory experiments (Ghiorse and Alexander 1976).

The $\mathrm{SO}_{4}{ }^{2-}-\mathrm{S}$ content of the 0 to $1 \mathrm{~cm}$ and 1 to $3 \mathrm{~cm}$ layers of both soils increased at those soils placed closest to the emission source (Table 24). Analysis of variance indicated that for a given soil and depth, $\mathrm{SO}_{4}^{2-}-\mathrm{S}$ content was significantly $(\mathrm{p}=0.05)$ different between sites. The hydrogen ion concentrations (calculated from soil pH) in the top $1 \mathrm{~cm}$ of the sandy 0 .EB soil were significantly $(p=0.01)$ correlated $\left(r^{2}=0.65\right)$ with the total sulphation values at each site (Section 8.7 ).

Analysis of the soils for total sulphur in 1977 revealed that the soils nearest the emission source had absorbed larger quantities of $\mathrm{SO}_{2}$ from the air than had been indicated by the $\mathrm{SO}_{4}{ }^{2-}-\mathrm{S}$ results (Table 24). The total $S$ content of both soils was very variable and most likely reflects differing amounts of organic matter in the soil samples selected for each site. The total $S$ values for both peat and pine sand are unusually high at Algar and May where low values would be exptected. However, the total S 


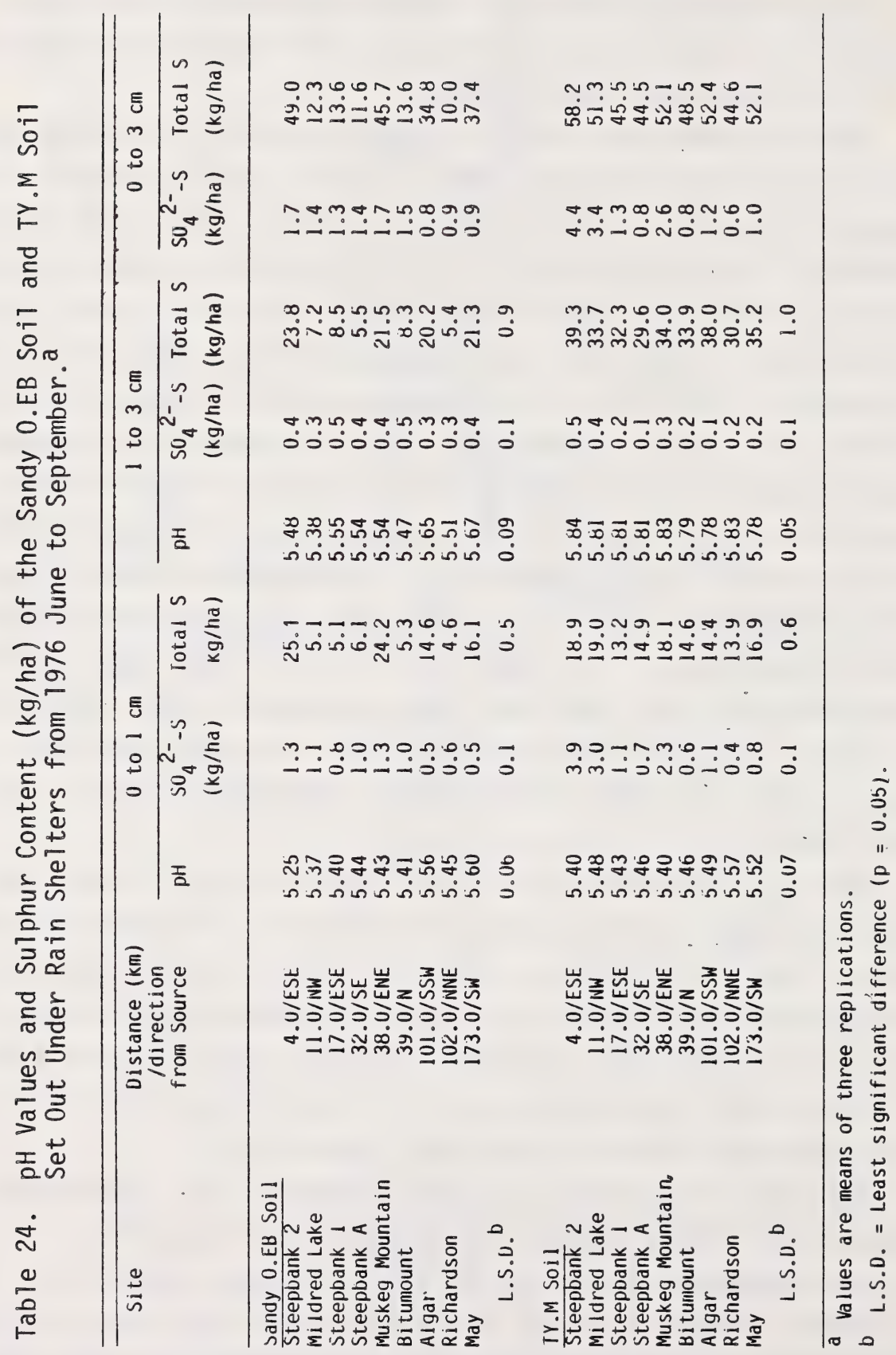


content of both pine sand and peat was correlated to the average total sulphation values at each site (Section 8.7 ). This correlation explained 54\% of the variance in total $S$ content of peat. The hydrogen ion and $\mathrm{SO}_{4}{ }^{2-}-\mathrm{S}$ concentration in both the peat and pine sand were correlated with distance from the sulphur dioxide emission source and average total sulphation values at each site.

\subsubsection{Sulphur Uptake by Bare Soils - Controlled Atmosphere Experiment} The capacity of soils to absorb $\mathrm{SO}_{2}$ and the consequent depression of soil pH was demonstrated in a controlled atmosphere experiment in 1976. The pH and total $S$ values are shown in Table 25. All three soils decreased in $\mathrm{pH}$ and increased in total $S$ content after being exposed to sulphur dioxide for a period of 30 days. A t-test indicated that the decrease in $\mathrm{pH}$ was significant $(p=0.05)$ for both the $0 . B L$ soil and sandy $0 . E B$ soil but was not significant for the TY.M Soil. The increase in total $S$ was significant for sandy C.EB soil but not significant for the other two soils.

\subsubsection{Sulphur Uptake by Lichen Covered Soils - Field Experiment}

This experiment was designed to determine the rate of uptake of sulphur by an intact forest soil from the AOSERP study area. The soil was sampled so that the natural lichen cover and mineral soil remained undisturbed. Pots of this soil were set out in the field under rain shelters from May to October 1976. They had therefore been exposed to sulphur emissions for a period of five months.

The results (Table 26) indicate that the $\mathrm{SO}_{4}{ }^{2-}-\mathrm{S}$ and total $\mathrm{S}$ content of soils set out at the two field sites located nearest the emission source (Steepbank 2 and Muskeg Mountain) increased substantially over the exposure period. Al though the live lichen material had the largest increase in $\mathrm{SO}_{4}{ }^{2-}-\mathrm{S}$ and total $\mathrm{S}$ when expressed in ug $\mathrm{S} / \mathrm{g}$ material, the increase on an area basis was small because of the low bulk density of the lichen material. The layer below five $\mathrm{cm}$ depth (Ae horizon) did not absorb sulphur from the atmosphere. The live lichen material at both control sites increased in total $S$ content but this increase was much smaller than for the lichen material which had been exposed at two sites nearer the emission source. 
Table 25. Effect of $\mathrm{SO}_{2}$ Exposure, Under Controlled Conditionsa, on Soil $\mathrm{pH}$ Values and Total Sulphur Concentration. $\mathrm{b}$

\begin{tabular}{|c|c|c|c|c|c|c|}
\hline \multirow[b]{2}{*}{ Soir } & \multicolumn{3}{|c|}{ Control } & \multicolumn{3}{|c|}{ Exposed to $\mathrm{SO}_{2} \mathrm{e}$} \\
\hline & $\begin{array}{c}\mathrm{pHC}^{\left(\mathrm{H}_{2} \mathrm{O}\right)}\end{array}$ & $\begin{array}{l}\mathrm{pHd}^{\mathrm{d}} \\
\left(\mathrm{CaCl}_{2}\right)\end{array}$ & $\begin{array}{c}\text { Total } S \\
(\mathrm{ppm})\end{array}$ & $\begin{array}{c}\mathrm{pH} \\
\left(\mathrm{H}_{2} \mathrm{O}\right)\end{array}$ & $\begin{array}{c}\mathrm{pH} \\
\left(\mathrm{CaCl}_{2}\right)\end{array}$ & $\begin{array}{c}\text { Total } S \\
(\mathrm{ppm})\end{array}$ \\
\hline 0.BL Soil & 5.89 & 4.78 & 641 & 5.81 & 4.58 & 674 \\
\hline Sandy 0.EB Soil & 5.82 & 4.46 & 30 & 5.33 & 4.37 & 55 \\
\hline TY.M Soil & 5.68 & 4.40 & 1126 & 5.47 & 4.37 & 1142 \\
\hline
\end{tabular}

a Air temperature $=22^{\circ} \mathrm{C}$.

Average $\mathrm{SO}_{2}$ concentration $=70 \mathrm{ppb}$.

Average relative humidity $=60 \%$.

Length of exposure $=30$ days.

b Values are means of 3 replications for $\mathrm{pH}$, and 6 replications for total sulphur.

c $\mathrm{pH}$ in water.

d $\mathrm{pH}$ in $0.01 \mathrm{M} \mathrm{CaCl}_{2}$.

e Concerning statistical differences $(0=0.05)$ between control and $\mathrm{SO}_{2}$ exposed soil samples: $\mathrm{pH}$ values in water, all 3 soils were statistically less when exposed to $\mathrm{SO}_{2}$; for $\mathrm{pH}$ values in $\mathrm{CaCl}_{2}$ solution, only the $0 . B L$ soil and the sandy 0 .EB soil were statistically less when exposed; and for total $S$, only the sandy 0 . EB soil was statistically greater when exposed. 


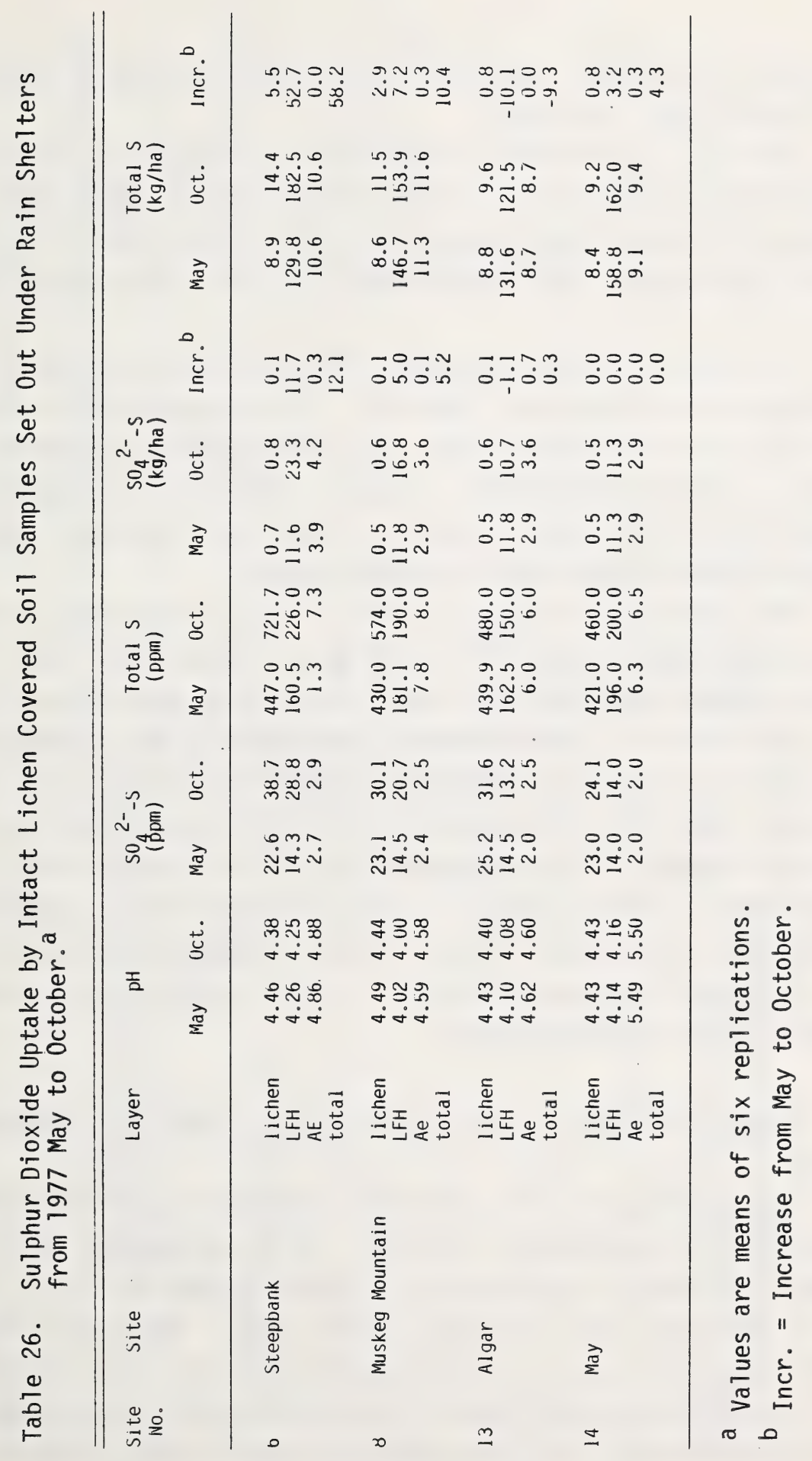


Inexplicably, the sulphur content of the LFH layer located at one of the control sites (Algar) decreased.

The $\mathrm{SO}_{4}{ }^{2-}-\mathrm{S}$ and total $\mathrm{S}$ content of a given layer at a given site was significantly different $(p=0.05)$ between the two sample dates. Analysis of variance also showed that the two-way interactions; site by layer, site by date, and layer by date, were significant $(p=0.05)$ for both $\mathrm{SO}_{4}{ }^{2-}-\mathrm{S}$ and total S.

In contrast to the experiments with bare soils, the $\mathrm{pH}$ of the lichen covered soil was not depressed (Table 26). There tended to be a decrease in the $\mathrm{pH}$ of the lichen material at the two sites nearest the emission source (Steepbank 2 and Muskeg Mountain). However, analysis of variance shows that differences in $\mathrm{pH}$ for a given layer, at a given site, were not significantly $(p<0.05)$ different between the two sample dates.

The considerable increase in total $S$ by the soils located nearest the emission source (particularly field site No. 6) demonstrates that an undisturbed sandy forest soil can absorb appreciable quantities of $\mathrm{SO}_{2}$ directly from the air. This absorption amounted to a net increase of total $S$ of $10.8 \mathrm{~kg} / \mathrm{ha} / \mathrm{month}$ and $1.2 \mathrm{~kg} / \mathrm{ha} /$ month for field site Nos. 6 and 8 , respectively. When this is compared to the sulphur deposition (as $\mathrm{SO}_{4}{ }^{2-}-\mathrm{S}$ ) in rainwater of $0.3 \mathrm{~kg} / \mathrm{ha} /$ month for field site No. 6 and $0.2 \mathrm{~kg} / \mathrm{ha} / \mathrm{month}$ for field site No. 8 , it is evident that dry deposition of sulphur by direct absorption of $\mathrm{SO}_{2}$ by soils is a major mechanism for the removal of sulphur from the atmosphere. This is particularly important in areas close to the emission source.

\subsubsection{Sulphur Uptake by Lichen Covered Soils - Controlled Atmosphere} Experiment

Data obtained from the controlled atmosphere experiment coroborates data from the field experiment (Table 27). After an exposure period of seven days, there was a significant $(p=0.05)$ increase in the $\mathrm{SO}_{4}{ }^{2-}-\mathrm{S}$ content of the lichen layer and top $2.5 \mathrm{~cm}$ of soil. There was a larger (but non-significant) increase in the total sulphur content of the lichen layer and mineral soil at both humidity levels. A significantly larger amount of sulphur was absorbed by the lichen layer and mineral soil at the $80 \%$ humidity 


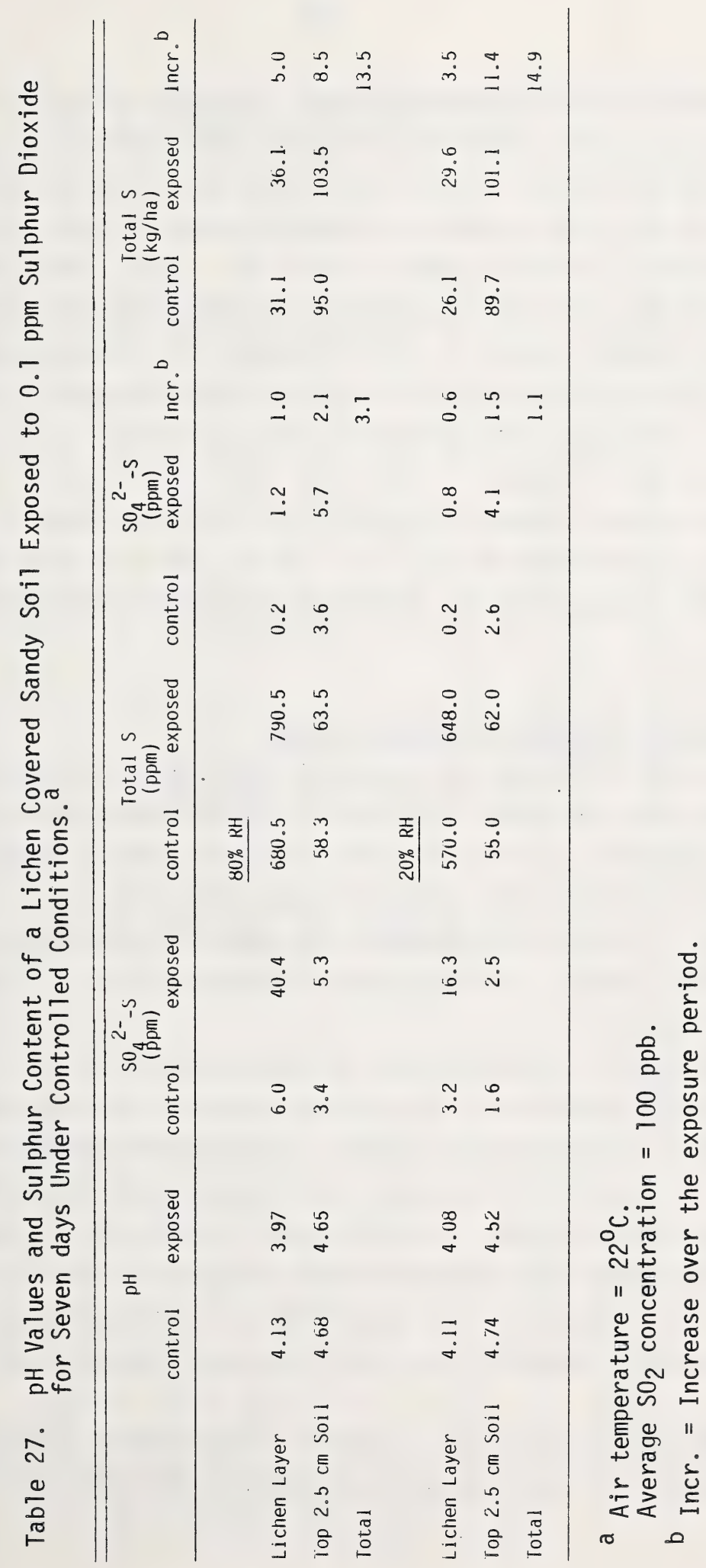


level compared to the $20 \%$ humidity level. This may be due to the increased moisture hastening the oxidation of $\mathrm{SO}_{2}$ and the reactions of its oxidation products with soil bases. Other researchers have shown an increase in the absorption of $\mathrm{SO}_{2}$ with increasing moisture content of soil (Terraglio et al. 1966) and the air moisture content (Yee et a1. 1975). These studies, however, only analysed the soils for $\mathrm{SO}_{4}{ }^{2-}-\mathrm{S}$ and Faller and Herwig $(1969 / 70)$ stated that the end product of soil $\mathrm{SO}_{2}$ absorption is sulphate. Our results show that for peat (Section 4.2.3), sulphate sulphur appears as the main end product. In this case, the absorption could be related to the moderate solubility of $\mathrm{SO}_{2}$ in water.

The larger increase in total $S$ indicates that only a fraction of the absorbed $\mathrm{SO}_{2}$ is recovered as $\mathrm{SO}_{4}{ }^{2-}-\mathrm{S}$. The $\mathrm{SO}_{2}$ was also able to penetrate the lichen layer and be absorbed by the mineral soil beneath (Table 27).

\subsubsection{Sulphur Content of Lysimeter Soils}

In July 1976, two soils in three replicates were set out at nine sites. The soils, an Orthic Gray Luvisol and an Orthic Eutric Brunisol were placed in lysimeters so that the plant cover and organic layers remained undisturbed (Section 3.2.5). The lysimeters were left out in the field until August 1978. They were then removed from the field and both soils were separated into layers. Each layer was analysed for $\mathrm{pH}, \mathrm{SO}_{4}{ }^{2-}-\mathrm{S}$ and total S (Sectio 8.8).

The total $S$ concentrations in the plants and organic layers of both soils are given in Table 28. The grasses and moss covering the 0.GL soil show a clear trend of decreasing total $S$ concentration with increasing distance from the emission source. The organic layers also show this trend. The concentrations of total $S$ in the organic layers are considerably larger at the two sites nearest the emission source compared to the two remote sites. The lichen and FH layers of the sandy C.EB soil do not show a trend of decreasing total $S$ concentration with increasing distance from the emission source.

The $\mathrm{SO}_{4}{ }^{2-}-\mathrm{S}$ and total $\mathrm{S}$ content of the organic layers and top $3 \mathrm{~cm}$ of mineral soil for both soils is shown in Table 29. The $\mathrm{SO}_{4}{ }^{2-}-\mathrm{S}$ 


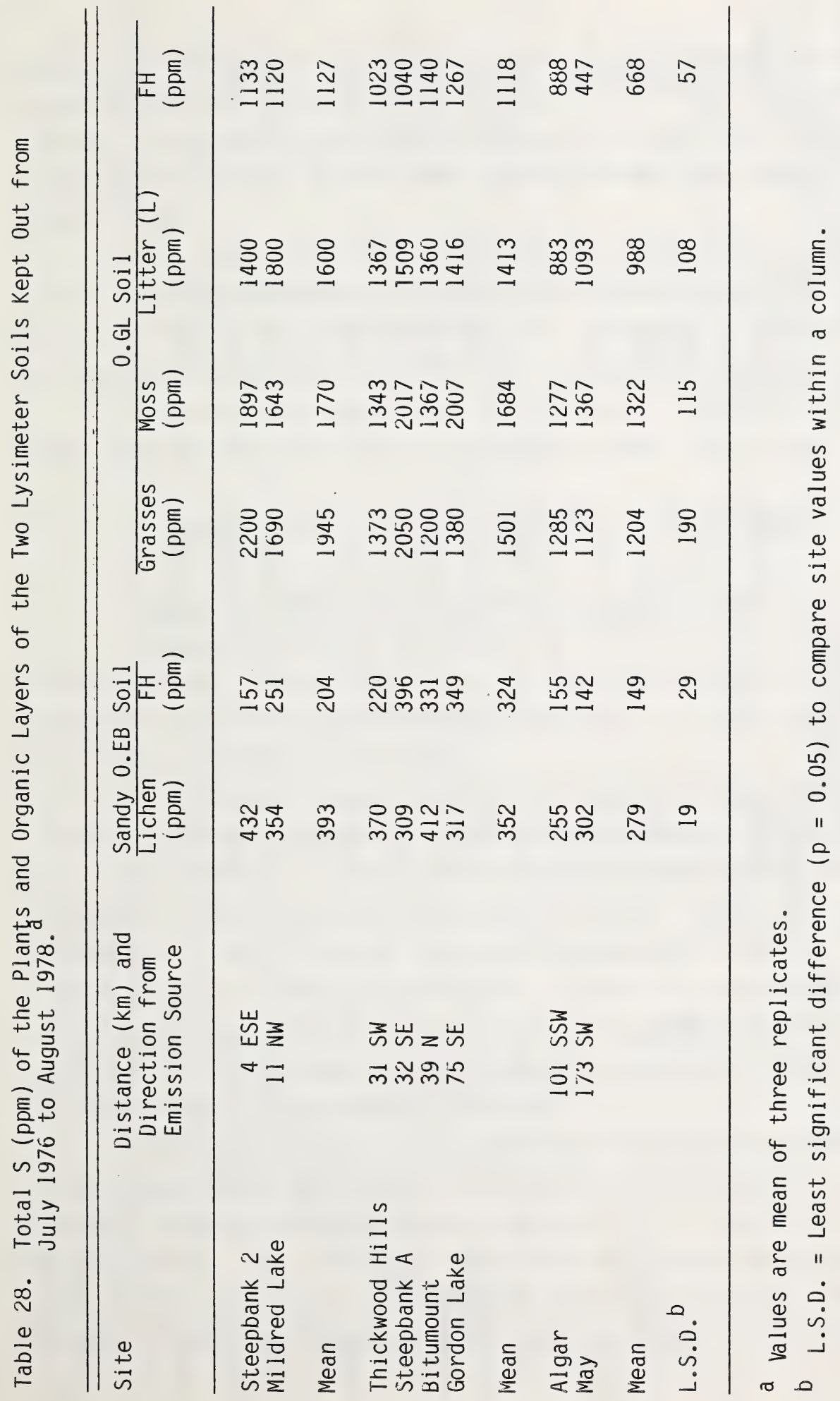




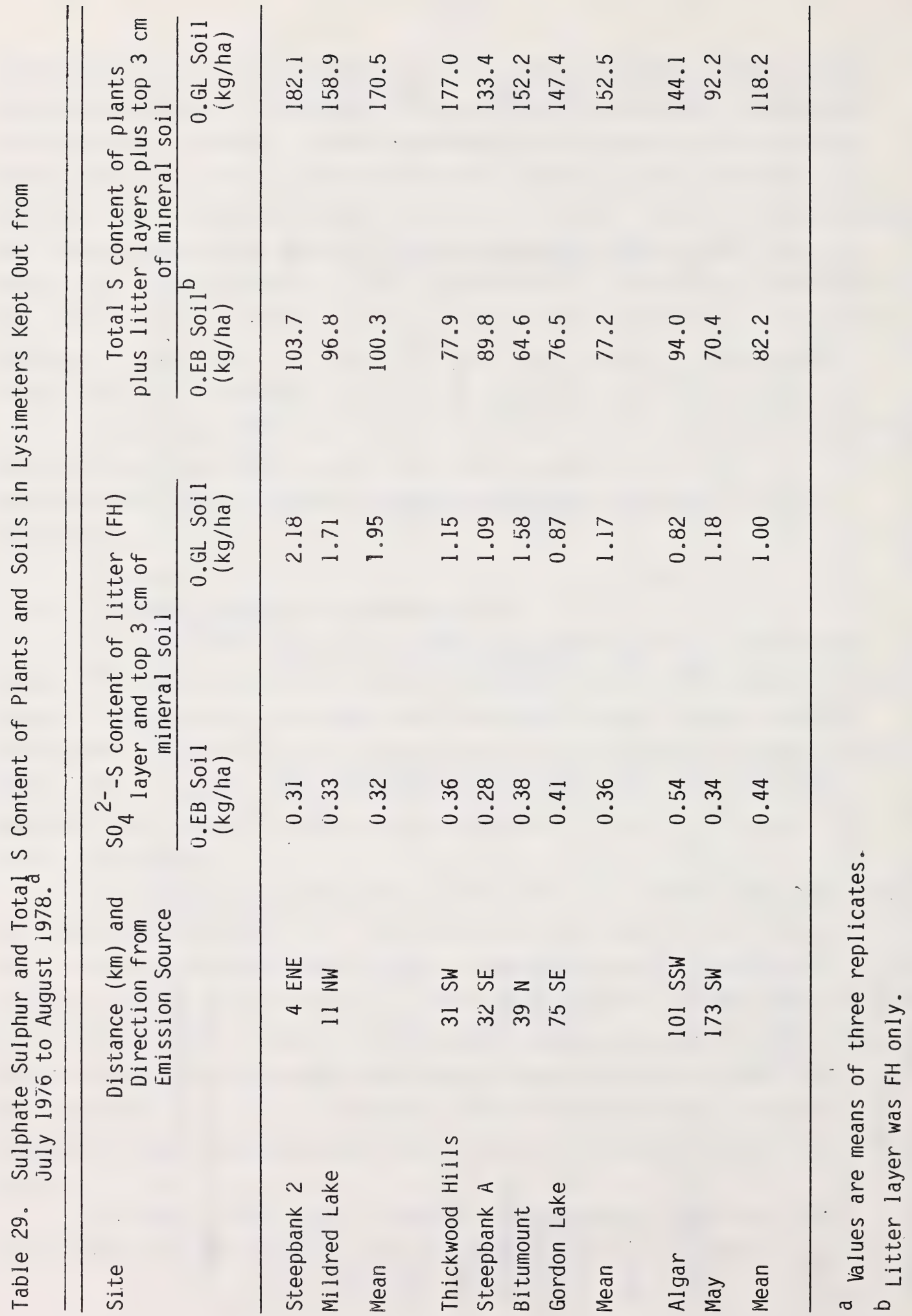


content of the top layers of the 0 . EB soil do not show any relation to distance from the emission source whereas the $0 . \mathrm{GL}$ soil shows such a trend. The $\mathrm{SO}_{4}{ }^{2-}-\mathrm{S}$ content of the surface layers of the 0 . EB soil increased by approximately $1 \mathrm{~kg} / \mathrm{ha}$ at the sites nearest the emission source compared to the remote sites.

The total $S$ content of 0 .EB soil also showed a clear trend of increasing with decreasing distance from the emission source. The total $S$ content of the surface layers of this soil increased by approximately $50 \mathrm{~kg} / \mathrm{ha}$ at the sites nearest the emission source compared to the remote sites.

There were no significant differences in the $\mathrm{pH}$ of both soils at sites near the emission source as compared to the remote sites (Section 8.8)

\subsection{MOVEMENT OF APPLIED SULPHATE SULPHUR IN FOREST SOILS}

\subsubsection{Sandy Soil (Mildred Lake Research Facility Site)}

Potassium sulphate was applied to the surface of a forest soil at two rates $(56 \mathrm{~kg} / \mathrm{ha} \mathrm{S}$ and $112 \mathrm{~kg} / \mathrm{ha} \mathrm{S})$. To determine changes over the summer period, the soil was sampled before (June) and four months after (September) the potassium sulphate was applied.

Preliminary results (Section 8.9) indicated that soil pH was not affected by the application of the potassium sulphate. At the low rate of application (56 kg/ha S), $\mathrm{SO}_{4}{ }^{2-}-\mathrm{S}$ had moved down about $60 \mathrm{~cm}$ into the soil while soluble $\mathrm{K}$ had moved down about $15 \mathrm{~cm}$. At the high application rate $(112 \mathrm{~kg} / \mathrm{ha} \mathrm{S}), \mathrm{SO}_{4}{ }^{2-}-\mathrm{S}$ and $\mathrm{K}^{+}$appeared to have moved about the same rate as for the low rate of application. Most of the recovered $\mathrm{SO}_{4}{ }^{2-}-\mathrm{S}$ was found in the top $30 \mathrm{~cm}$ of soil. Potassium appeared to be less mobile than $\mathrm{SO}_{4}{ }^{2-}-\mathrm{S}$. The low recovery of $\mathrm{SO}_{4}{ }^{2-}-\mathrm{S}$ and particularly $\mathrm{K}^{+}$makes interpretation of these results difficult.

The $\mathrm{SO}_{4}{ }^{2-}-\mathrm{S}$, total $\mathrm{S}$, and extractable potassium content of the soil one year after application of potassium sulphate is given in Table 30. The $\mathrm{SO}_{4}{ }^{2-}-\mathrm{S}$ values indicate that the applied $\mathrm{SO}_{4}{ }^{2-}-\mathrm{S}$ had moved down at least $60 \mathrm{~cm}$. Very little of the applied $\mathrm{SO}_{4}^{2-}-\mathrm{S}$ was recovered as $\mathrm{SO}_{4}{ }^{2-}-\mathrm{S}$ and, if considered in isolation, this would suggest that much of the $\mathrm{SO}_{4}{ }^{2-}-\mathrm{S}$ had been leached to depths greater than was sampled or much 


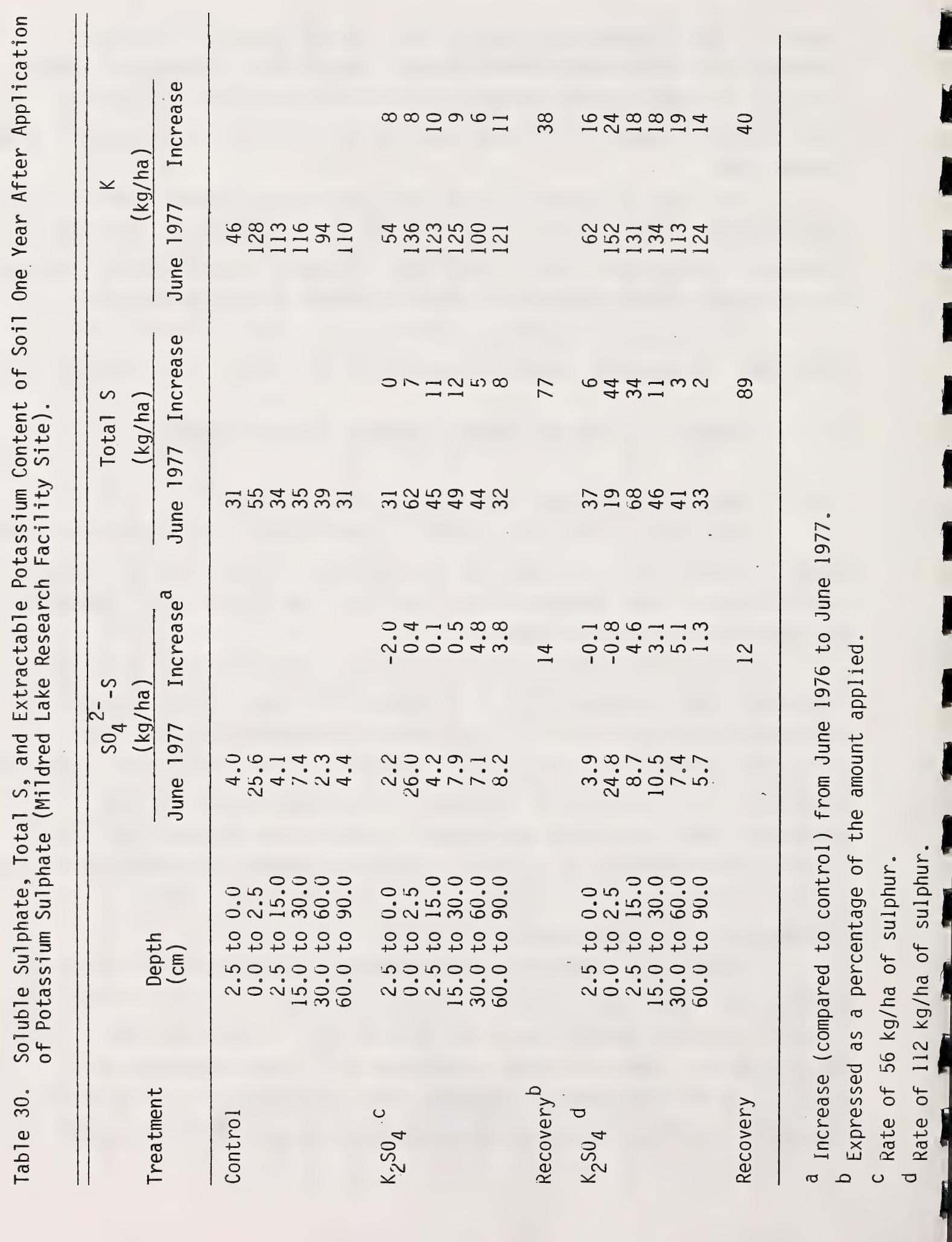


was taken up by vegetation (primarily jack pine trees). The total $S$ values also indicate that the applied $\mathrm{SO}_{4}{ }^{2-}-\mathrm{S}$ had moved down at least $60 \mathrm{~cm}$ soil depth. However, the total $S$ values show that a much higher proportion of the applied sulphur had remained within the sampling depth. The differences in the $\mathrm{SO}_{4}{ }^{2-}-\mathrm{S}$ and total $\mathrm{S}$ values at each soil depth suggest that much of the applied $\mathrm{SO}_{4}{ }^{2-}-\mathrm{S}$ was converted to a non-extractable form.

The applied $\mathrm{K}^{+}$leached dowan at least to $60 \mathrm{~cm}$, but only a small fraction of the applied $\mathrm{K}^{+}$was recovered in the $2 \mathrm{~N} \mathrm{NaCl}$ soil extract. This suggests that a large amount of the applied $\mathrm{K}^{+}$was taken up by vegetation.

\subsubsection{Clay Loam Soil (Thickwood Hills Site)}

Four months after the application of $\mathrm{K}_{2} \mathrm{SO}_{4}$, the $\mathrm{SO}_{4}{ }^{2-}-\mathrm{S}$ had moved down into the soil about $30 \mathrm{~cm}$ at this site compared to about $60 \mathrm{~cm}$ at the Mildred Lake site (Section 8.9). A much larger proportion of the $\mathrm{SO}_{4}{ }^{2-}$-S applied was recovered at this site compared to the Mildred Lake site. These differences may be due to the higher clay content of the soil at the Thickwood Hills site (Table 4). MacIntire et al. (1952) have demonstrated that silicate clays strongly absorb $\mathrm{SO}_{4}{ }^{2-}-\mathrm{S}$.

After one year, very little of the applied $\mathrm{SO}_{4}{ }^{2-}-\mathrm{S}$ was recovered (Table 31 ). The total $S$ analyses show that some of the applied $\mathrm{SO}_{4}{ }^{2-}-\mathrm{S}$ had moved down to a depth of at least $60 \mathrm{~cm}$. Most of the recovered $\mathrm{SO}_{4}{ }^{2-}-\mathrm{S}$ was, however, found in the top $30 \mathrm{~cm}$ of soil. As for the sandy soil, there was a large difference in the recovery of applied $\mathrm{SO}_{4}{ }^{2-}-\mathrm{S}$ as indicated by the $\mathrm{SO}_{4}{ }^{2-}-\mathrm{S}$ analyses and the total $\mathrm{S}$ analyses. This suggests that much of the applied $\mathrm{SO}_{4}{ }^{2-}-\mathrm{S}$ was converted to a non-extractable form. This discrepancy was largest in the top $30 \mathrm{~cm}$ of soil (Tables 30 and 31 ). The applied $\mathrm{SO}_{4}{ }^{2-}-\mathrm{S}$ may have become incorporated into the soil organic matter where it would not be recovered as soluble $\mathrm{SO}_{4}{ }^{2-}$-S but would be recovered in the total $S$ analyses.

As for the Mildred Lake site, the applied $\mathrm{K}^{+}$was leached down to at least the $60 \mathrm{~cm}$ depth and only a small fraction of the applied $\mathrm{K}^{+}$was recovered.

The results of this experiment show that $\mathrm{SO}_{4}{ }^{2-}-\mathrm{S}$ applied to the surface of a sandy soil and clay loam soil in the AOSERP study area is rapidly 


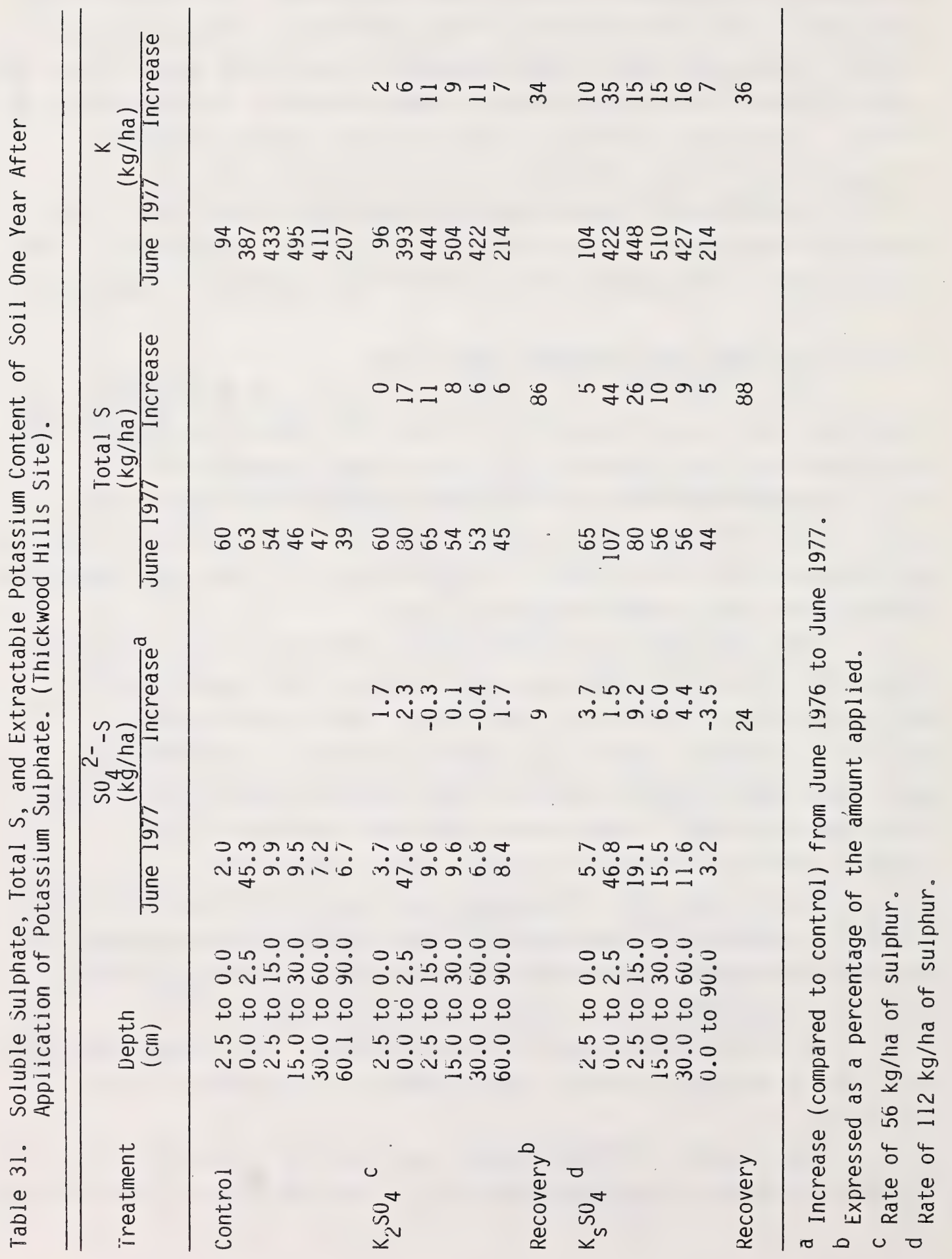


leached downward. It has also shown that the traditional method of analysing soil for sulphur content (soluble $\mathrm{SO}_{4}{ }^{2-}-\mathrm{S}$ ) is not an accurate method for determining the fate of deposited $\mathrm{SO}_{4}{ }^{2-}-\mathrm{S}$ in soil. Much of the applied $\mathrm{SO}_{4}{ }^{2-}-\mathrm{S}$ was transformed into an unextractable form.

\subsection{EFFECTS OF APPLIED ELEMENTAL SULPHUR, SULPHURIC ACID, AND LIME IN SOIL ACIDITY}

The aim of these experiments was to obtain information on the effects of simulated acid precipitation on forest soils in the AOSERP study area. The effects of acid precipitation on soil properties and processes are undoubtedly very complex. Long-term field experiments were therefore established so that the interactions of climate, vegetation, and organic and inorgganic matter were largely undisturbed. Liming experiments were also established as this will most likely be the primary method used to counteract excessive soil acidity.

\subsubsection{Effects of Applied Sulphuric Acid}

4.4.1.1 Sandy Soil (Mildred Lake Research Facility Site). The change in pH and the $\mathrm{SC}_{4}{ }^{2-}-\mathrm{S}$ content of the sandy soil four months after application of $\mathrm{H}_{2} \mathrm{SO}_{4}$ is shown in Table 32. For both application rates, $\mathrm{pH}$ has been depressed and the $\mathrm{SO}_{4}{ }^{2-}-\mathrm{S}$ content increased down to at least $60 \mathrm{~cm}$. The change in $\mathrm{pH}$ which resulted from the addition of $\mathrm{H}_{2} \mathrm{SO}_{4}$ reflects the low buffering capacity of the sandy soil at this site.

\subsubsection{Clay Loam Soil (Thickwood Hills Site). As for the sandy soil, the} application of $\mathrm{H}_{2} \mathrm{SO}_{4}$ at $280 \mathrm{~kg} / \mathrm{ha}$ lowered soil $\mathrm{pH}$ to a depth of $90 \mathrm{~cm}$. Sulphate sulphur was also found to have moved down at about $90 \mathrm{~cm}$ (Table 33). The decrease in $\mathrm{pH}$ of the top $15 \mathrm{~cm}$ of soil was less at this site than at the Mildred Lake site. This reflects the higher buffering capacity of this clay loam soil as compared to the sandy soil at the Mildred Lake site. The bulge in $\mathrm{SO}_{4}{ }^{2-}-\mathrm{S}$ concentrations in the clay loam occurred at a depth of 15 to $30 \mathrm{~cm}$, whereas the greatest $\mathrm{pH}$ decrease occured in the top $2.5 \mathrm{~cm}$ of soil. This suggests that in the top layers of soil, hydrogen ions 


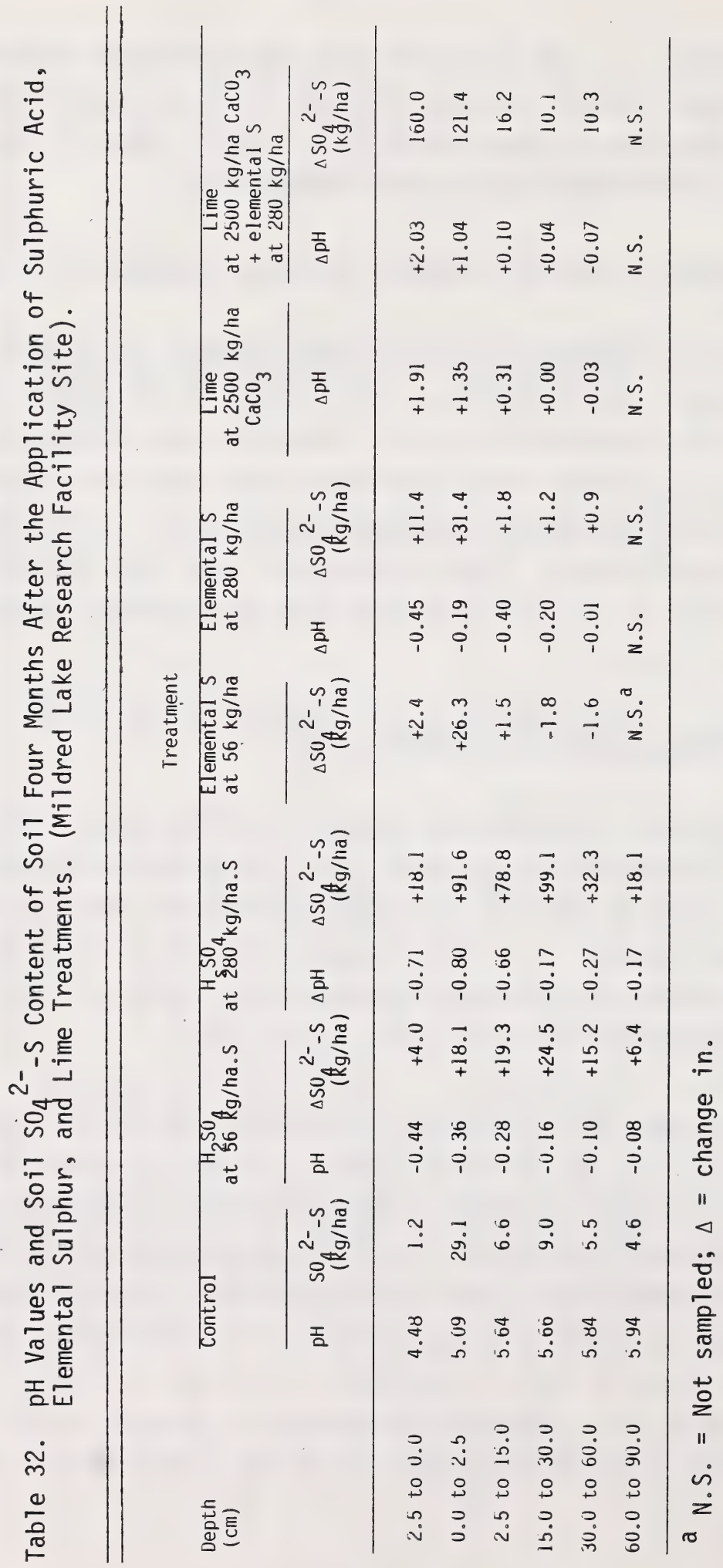




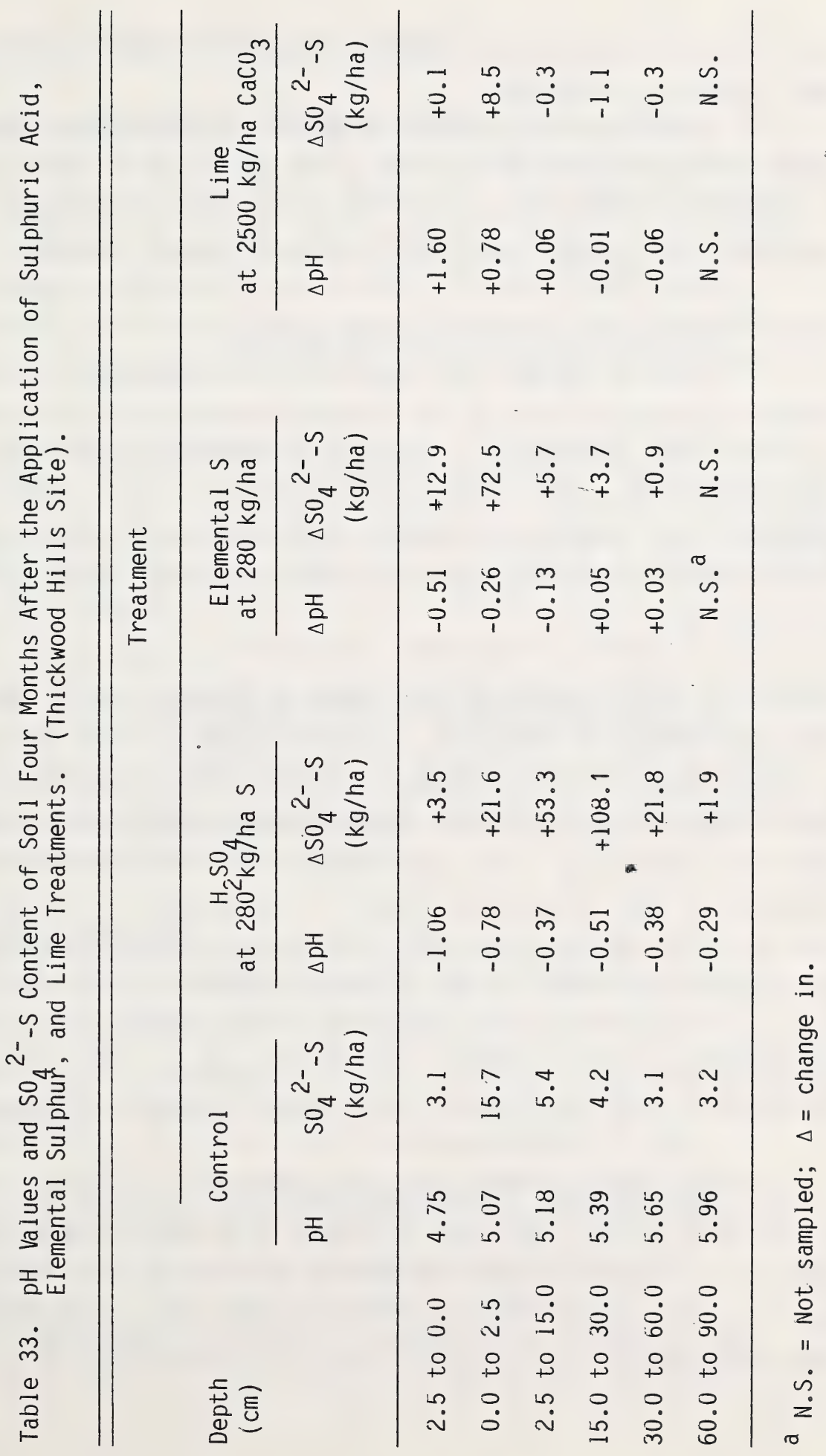


have replaced cations on the exchange complex and the displaced cations have been leached as sulphates.

Abrahamsen et a1. (1976) found that a significant reduction in the degree of base saturation occurred in the top layer of soil subject to $50 \mathrm{~mm} / \mathrm{month}$ of "rain" of $\mathrm{pH} 3.0$. The $\mathrm{pH}$ decrease at the lower depths indicates that hydrogen ions have also been leached downward.

\subsubsection{Effects of Applied Elemental Sulphur}

Elemental sulphur was applied in this experiment to give a slow release of sulphuric acid as the elemental sulphur was oxidized by microbes in the soil. This treatment was designed to simulate a lower rate of acid precipitation than that of the applied sulphuric acid treatments. The results presented here refer to the samples taken four months after the application of the elemental sulphur and therefore the oxidation of the elemental sulphur was not complete.

\subsubsection{Sandy Soil (Mildred Lake Research Facility Site). Application of} elemental sulphur at $280 \mathrm{~kg} / \mathrm{ha} S$ caused a decrease in $\mathrm{pH}$ only down to a depth of $30 \mathrm{~cm}$ (Table 32 ). The decrease in $\mathrm{pH}$ cause by elemental sulphur was less than for applied $\mathrm{H}_{2} \mathrm{SO}_{4}$ and the downward movement of acid was also less. This was probably due to the slow oxidation of the elemental sulphur and is reflected in the low recovery of $\mathrm{SO}_{4}{ }^{2-}-\mathrm{S}$ in the soil. The addition of lime at a rate of $2500 \mathrm{~kg} / \mathrm{ha} \mathrm{CaCO}_{3}$ fully negated any acidifying effect of the sulphur (Table 32) and the $\mathrm{pH}$ of the top $15 \mathrm{~cm}$ of soil was increased. There was a higher recovery of $\mathrm{SO}_{4}{ }^{2-}-\mathrm{S}$ in this treatment as compared to the application of elemental $S$ only. This suggests that the addition of lime increased the rate of oxidation of elemental sulphur to sulphate sulphur.

\subsubsection{Clay Loam Soil (Thickwood Hills Site). Application of $280 \mathrm{~kg} / \mathrm{ha} \mathrm{S}$} to this soil caused a decrease in $\mathrm{pH}$ down to a depth of about $15 \mathrm{~cm}$ (Table 33). Sulphate sulphur moved down to about $30 \mathrm{~cm}$. The movement of $\mathrm{SO}_{4}{ }^{2-}$-S and the downward movement of hydrogen ions was much less for this treatment than for a similar amount of sulphur applied as $\mathrm{H}_{2} \mathrm{SO}_{4}$. 


\subsubsection{Effects of Applied Lime on Soil Acidity}

\subsubsection{Sandy Soil (Mildred Lake Research Facility Site). After a period} of four months, application of lime at a rate of $2500 \mathrm{~kg} / \mathrm{ha}$ had raised the soil pH down to a depth of about $15 \mathrm{~cm}$ (Table 32). Ths downward movement could have been achieved in part by small particles of $\mathrm{CaCO}_{3}$ being washed into the soil pores by percolating water where the particles slowly dissolved. On this sandy soil, liming appears to be an effective method for counteracting soil acidity in the rooting zone of most shrubs and forbs.

\subsubsection{Clay Loam Soil (Thickwood Hills Site). The downward movement of} lime was much slower in this soil than for the sandy soil. The influence of lime on soil pH was largely restricted to the top $2.5 \mathrm{~cm}$ of soil four months after the application of the lime (Table 33). Soil pH was increased slightly in the 2.5 to $15.0 \mathrm{~cm}$ depth.

These results must be regarded as tentative at present as the full effects of liming on soil properties have yet to be investigated. Abrahamsen et a1. (1976) found that the addition of lime to forest soils caused a decrease in the potassium content presumably from exchange with the added calcium. However, they found exchangeable Mn was decreased also, because of decreased solubility at the higher soil $\mathrm{pH}_{\mathrm{a}}$.

\subsection{LYSIMETER EXPERIMENT}

The $\mathrm{pH}$ and $\mathrm{SO}_{4}{ }^{2-}-\mathrm{S}$ concentrations in the lysimeters leachate from the Orthic Eutric Brunisolic and the Orthic Gray Luvisolic soils collected over the summer of 1977 are shown in Tables 60 and 61 (Section 8.10).

The $\mathrm{pH}$ of the leachate from both soils was not related to the $\mathrm{pH}$ of rainwater at each site. The $\mathrm{pH}$ and $\mathrm{SO}_{4}{ }^{2-}-\mathrm{S}$ concentrations in the leachate from both soils at Supertest Hill were, however, unusually high. These lysimeters were located under trembling aspen trees and most likely received additional $\mathrm{SO}_{4}{ }^{2-}-\mathrm{S}$ in aspen throughfall (Section 4.1.1.2)

For both soils, there was a decrease in leachate $\mathrm{SO}_{4}{ }^{2-}-\mathrm{S}$ concentrations with increasing distance from the emission source. The relative amounts of $\mathrm{SO}_{4}{ }^{2-}-\mathrm{S}$ leached from the lysimeters at each site are 
given in Table 34. These values are weighted so that the amount of rain and the amount of leachate were equivalent at each site. The relative amounts of $\mathrm{SO}_{4}{ }^{2-}$-S leached from the $\mathrm{O}$. EB soil was strongly correlated with the amounts of $\mathrm{SO}_{4}{ }^{2-}-\mathrm{S}$ deposited in rain at each site $\left(r^{2}=0.96\right.$, $p=0.001)$. This relationship was much weaker for the $0 . G L\left(r^{2}=0.48\right.$, $p=0.05)$.

The concentrations of cations in the lysimeter leachates are given in Tables 62 and 63 (Section 8.10). The soil leachate at Supertest Hill contained the highest concentrations of cations, particularly calcium. Calcium was the predominant cation in the leachate from both soils.

The relative amounts of calcium deposited in the lysimeter leachates at each site are shown in Table 35 . The relative amounts of calcium deposited in the C.EB soil leachate and the O.GL soil leachate were not significantly correlated with the amounts of calcium deposited in rain at each site. The relative amounts of calcium in the 0 . EB soil leachate at each site was correlated to the amounts of $\mathrm{SO}_{4}{ }^{2-}-\mathrm{S}$ in the leachate $\left(r^{2}=0.71\right.$, $p=0.001)$. There was no significant correlation between the amounts of calcium and $\mathrm{SO}_{4}{ }^{2-}$-S leached at each site for the $0 . \mathrm{GL}$ soil.

other experiments (Section 4.3) have demonstrated that $\mathrm{SO}_{4}{ }^{2-}-\mathrm{S}$ applied to the surface of sandy soils such as the 0 .EB soil used in this experiment is readily leached down through the soil column. These results imply that $\mathrm{SO}_{4}{ }^{2-}$-S deposited on the sandy $\mathrm{O}$. EB soil in rain was washed down through the soil and collected as leachate. The strong correlation between the amounts of calcium and $\mathrm{SO}_{4}{ }^{2-}-\mathrm{S}$ in the leachate suggests that calcium was leached from the soil in association with the leached $\mathrm{SO}_{4}{ }^{2-}$-S. Such a process would cause a decrease in soil base content.

\subsection{PERMANENT SOIL PLOTS}

The $\mathrm{pH}$ and total $\mathrm{S}$ content of the permant plot soils is given in Section 8.11. Because of the change in sampling between 1976 and 1978, only the values for the litter layers are directly comparable.

The $\mathrm{pH}$ values are variable, and there is no clear trend to an increase or decrease. The total $S$ values also indicate that there is no clear change in 1976 to 1978. 


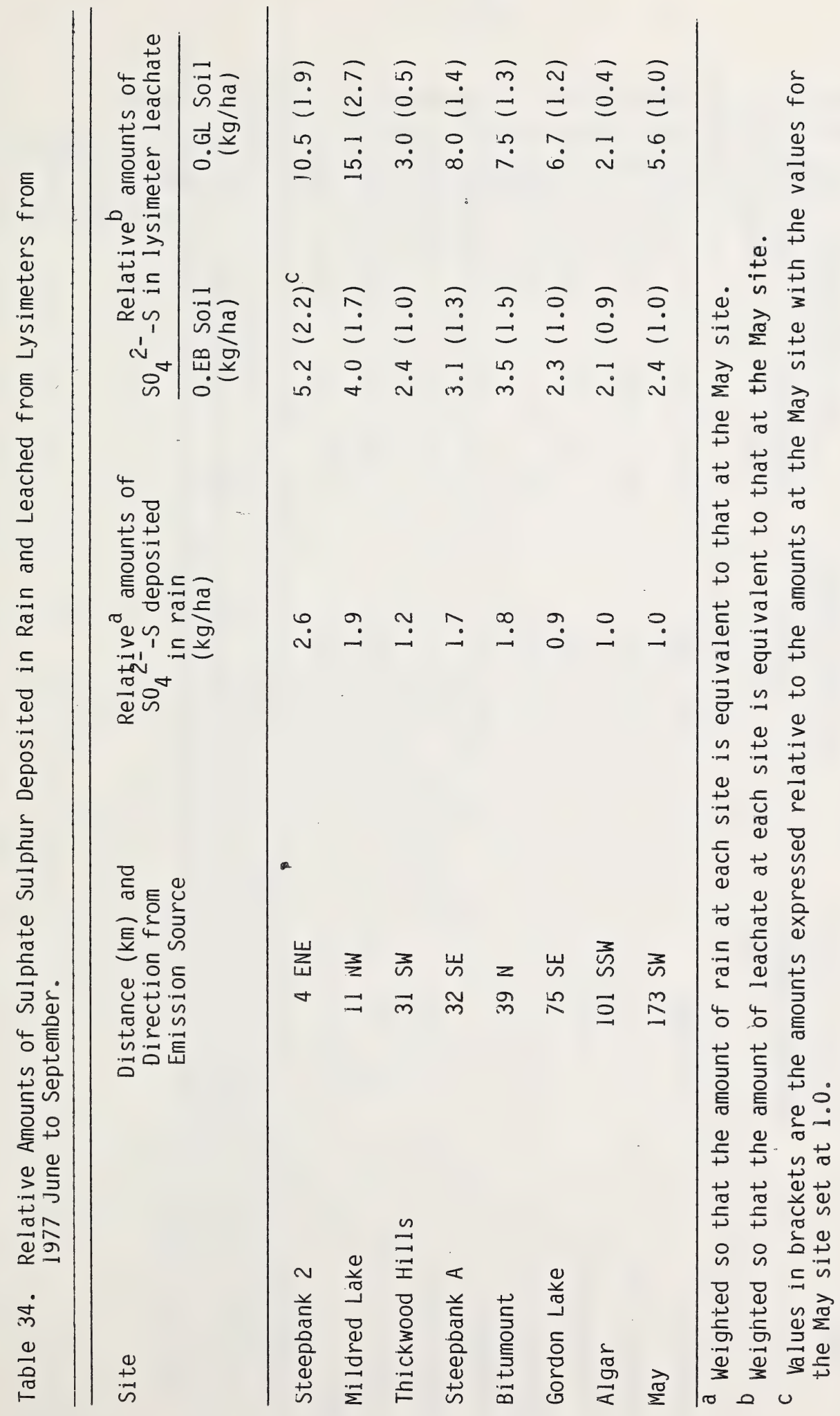


86

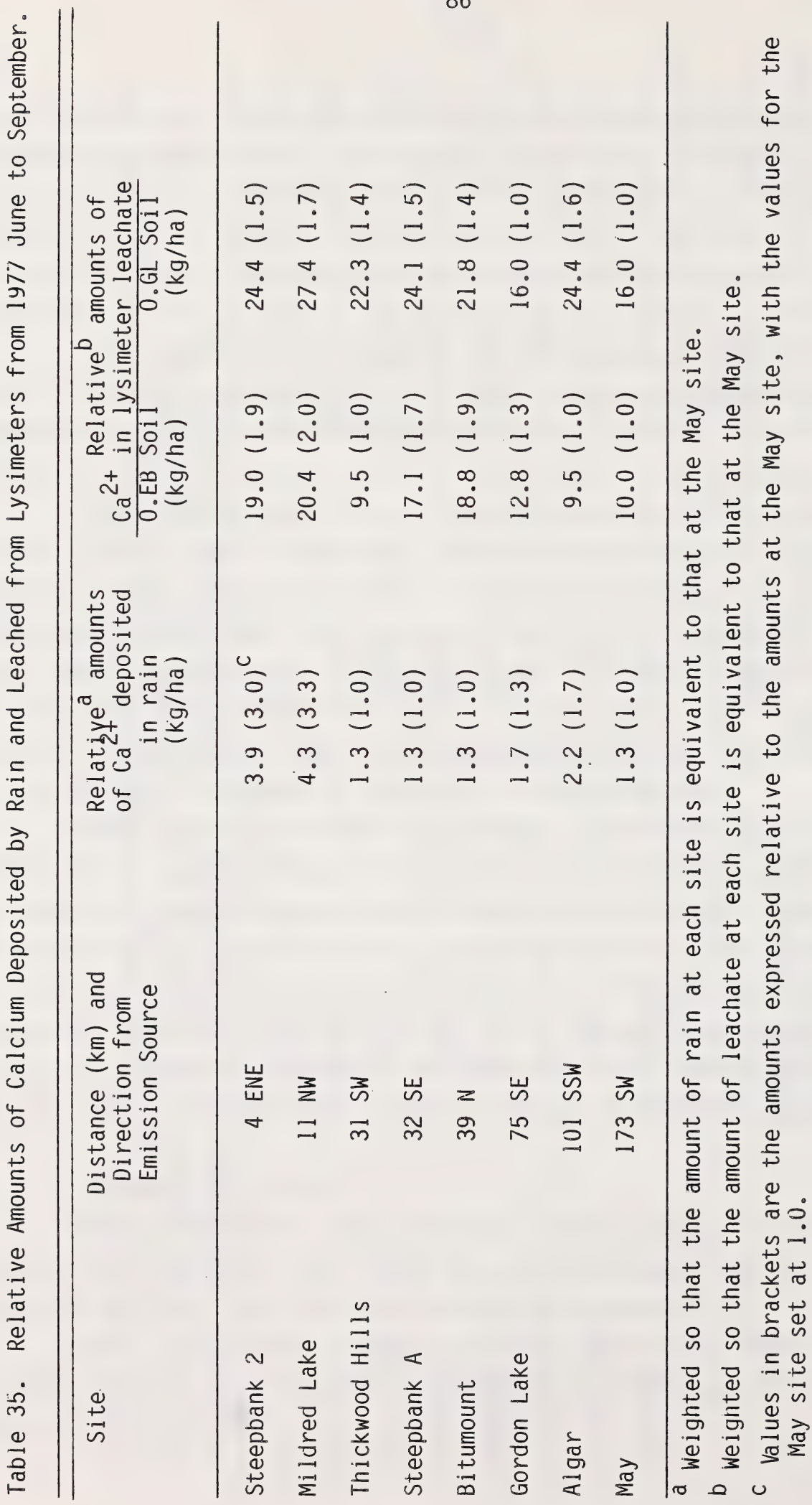


Because of the variable nature in soil properties, no conclusions can be drawn from these initial results. These values will provide a baseline for the AOSERP study area, and it is recommended that these plots be sampled again every few years. 
5. CONCLUSIONS

The results presented in this report concern the pathways by which anthropogenic sulphur may find its way into soil, how much sulphur was deposited, what were the resultant forms of this sulphur in soil, and if the soils were acidified by this deposition of sulphur. The mechanisms of sulphur deposition investigated were: rain, snow, rain washing off trees, and direct absorption of $\mathrm{SO}_{2}$ by soil. The conclusions drawn from this study are as follows:

1. The amount of $\mathrm{SO}_{4}{ }^{2-}-\mathrm{S}$ deposited in rain in the AOSERP study area is low. In 1975, an average of 0.8 to $1.1 \mathrm{~kg} / \mathrm{ha} / \mathrm{month}$ was deposited at sites near the emission source compared to about a $3 \mathrm{~kg} / \mathrm{ha} /$ month at remote sites. In 1976 and 1977, at sites close to the emission source, the amount of $\mathrm{SO}_{4}{ }^{2-}-\mathrm{S}$ deposited averaged 0.3 to $0.6 \mathrm{~kg} / \mathrm{ha} / \mathrm{mon}$ th while at remote sites about 0.25 $\mathrm{kg} / \mathrm{ha} /$ month was deposited.

2. The amounts of $\mathrm{SO}_{4}{ }^{2-}-\mathrm{S}$ deposited in rain washing off trees were greater than that deposited in rain. There was also greater deposition of $\mathrm{SO}_{4}{ }^{2-}-\mathrm{S}$ in net precipitation (throughfall plus stemflow) at sites close to the emission source compared to remote sites. In 1976, approxiamtely 0.5 to $4.7 \mathrm{~kg} / \mathrm{ha} /$ month, $\mathrm{SO}_{4}{ }^{2-}-\mathrm{S}$ was deposited at exposed sites compared to 0.4 to $0.6 \mathrm{~kg} / \mathrm{ha} / \mathrm{month}$ at remote sites, depending on the tree species. The amounts of sulphur deposited in net precipitation represents a more accurate measure of the amounts of sulphur deposited on soils in the AOSERP study area than that determined from incident precipitation samples.

3. The acidity of rain decreased as it passed through the canopy of trembling aspen. This removal of hydrogen ions by exchange in the canopy could lessen the potential impact of acid precipitation on soils under aspen stands in the AOSERP study area.

The acidity of rain increased as it passed through the canopy of jack pine trees. The acidity of jack pine throughfall and stemflow also was greater at sites exposed to $\mathrm{SO}_{2}$ as compared 
to control sites. Throughfall was lower in $\mathrm{pH}$ by about 0.3 units and stemflow was lower by about 0.8 to $1.1 \mathrm{pH}$ units. At a site near the emission source, deposition of free acid $\left(\mathrm{H}^{+}\right)$ under jack pine trees was highly correlated with deposition of $\mathrm{SO}_{4}{ }^{2-}$-S. No such correlation was evident at a control site.

For both jack pine and trembling aspen, larger quantities of the cations $\mathrm{K}^{+}, \mathrm{Ca}^{2+}$, and $\mathrm{Mg}^{2+}$ were removed from the canopies at a site close to the emission source compared to a more remote control site.

4. Deposition of $\mathrm{SO}_{4}{ }^{2-}-\mathrm{S}$ in snow is low. In 1976, about $0.15 \mathrm{~kg} / \mathrm{ha} / \mathrm{month}$ was deposted at sites close to the emission source compared to less than $0.10 \mathrm{~kg} / \mathrm{ha} /$ month at more distant sites.

5. Bare soils were found to absorb $\mathrm{SO}_{2}$ directly from the air. This absorption process resulted in the formation of compounds. In some soils, the increase in total. $S$ was greater than the increase in $\mathrm{SO}_{4}{ }^{2-}-\mathrm{S}$. That is, the usual method of determining $\mathrm{SO}_{4}$ absorption by soils $\left(\mathrm{SO}_{4}{ }^{2-}-\mathrm{S}\right.$ analysis) leads to an underestimation in some cases. The absorption of $\mathrm{SO}_{2}$ by bare soils was also shown to result in a significant increase in the acidity of the top layer $(0$ to $1 \mathrm{~cm})$ of soil. The $\mathrm{pH}$ of the top $1 \mathrm{~cm}$ of a bare sandy soil decreased by approximately $0.25 \mathrm{pH}$ units at a site $4 \mathrm{~km}$ from the emission source as compared to a site $100 \mathrm{~km}$ from the emission source.

6. Lichen covered soils, sampled in the AOSERP study area, were also found to absorb $\mathrm{SO}_{2}$ directly from the air. The sulphur uptake was restricted to the live lichen material and top few centimetres of organic material. The amount of sulphur absorbed by 1 ichen covered soils was of the order of $10 \mathrm{~kg} / \mathrm{ha} / \mathrm{month}$ at sites immediately downwind from the emission source. Corresponding values of sulphur deposition in rain and net precipitation (throughfall plus stemflow) at the same sites were approximately $0.3 \mathrm{~kg} / \mathrm{ha} / \mathrm{mon}$ th and $0.6 \mathrm{~kg} / \mathrm{ha} / \mathrm{month}$, respectively. 
The surface layers of a sandy soil (1ysimeter experiment) increased in sulphur content by approximately $20 \mathrm{~kg} / \mathrm{ha}$ at sites near the emission source over a two-year period. The surface layers of a clay loam soil increased by approximately $50 \mathrm{~kg} / \mathrm{ha}$ over the same period. Corresponding amounts of sulphur deposited in rain and snow were of the order of $4.0 \mathrm{~kg} / \mathrm{ha}$ and $2.0 \mathrm{~kg} / \mathrm{ha}$, respectively. Absorption of $\mathrm{SO}_{2}$ directly from the air by soils therefore amounted to the most important sulphur deposition mechanism in the AOSERP study area, particularly in areas close to the emission source.

7. Field experiments demonstrated that $\mathrm{SO}_{4}{ }^{2-}-\mathrm{S}$ deposited on soils in the AOSERP study area was rapidly leached downward. Sulphate applied to the soil surface as a neutral salt $\left(\mathrm{K}_{2} \mathrm{SO}_{4}\right)$ moved downward as much as 30 to $60 \mathrm{~cm}$ into a sandy soil and a clay loam soil over a 12-month period. Sulphuric acid applied, to the surface of two forest soils, also moved quite rapidly through the soil and caused an increase in the acidity of the soil as it moved downward. Ground limestone applied to the surface of these same soils effectively counteracted the acidifying effect of the applied sulphuric acid.

A lysimeter experiment showed that calcium was the principal cation leached from a sandy and a clay loam soil from the AOSERP study area. In the leachate from the sandy soil, the relative amount of calcium was strongly correlated with the relative amounts of $\mathrm{SO}_{4}{ }^{2-}-\mathrm{S}$.

8. The surface few centimetres of bare and lichen covered sandy soils set out in canisters in the AOSERP study area absorbed $\mathrm{SO}_{2}$ and decreased in $\mathrm{pH}$, particularly at sites nearest the emission source. The increase in soil acidity was of the order of 0.1 to $0.3 \mathrm{pH}$ units over the summer period. However, soil acidity of lysimeter soils (with the surface layers undisturbed) set out for two years showed no significant difference between control and exposed sites. Soil pH tends to fluctuate with the 
soil moisture content and soil temperature and changes in $\mathrm{pH}$ were only noted in carefully controlled experiments. Long-term monitoring of soils is needed to determine if the $\mathrm{pH}$ of forest soils is being decreased by sulphur emissions in the AOSERP study area.

9. In general, the soils associated with jack pine would be expected to be the most susceptible to acidification in the AOSERP study area. Jack pine stands are more open and have less dense lower vegetative cover than trenbling aspen or mixed wood stands. Sulphur dioxide would more readily be able to come into direct contact with the ground surface at these sites. In addition, increased deposition of acid beneath jack pine was shown to result from sulphur emissions in the AOSERP study area. Jack pine commonly grows on coarse, acidic soils (Pawluk and Arneman 1961). Such sandy soils sampled from jack pine areas in the AOSERP study area were found to be poorly buffered against acid and were depressed in $\mathrm{pH}$ upon exposure to $\mathrm{SO}_{2}$ in both controlled atmosphere and field experiments. Sulphate sulphur was also shown to be mobile in the soils. Leaching of deposited sulphate sulphur through the soil would case a depletion of the already low base status of these soils. These facts indicate that the sandy soils associated with jack pine are the most susceptible to acidification caused by sulphur emissions. These soils should be carefully monitored to determine if the process of soil acidification is occurring in the AOSERP study area. 
6.

RECOMMENDATIONS FOR FURTHER RESEARCH

The most needed immediate research in soils, based on findings made under program LS 4.2, is the following:

1. The determination of the amount of sulphur deposition on vegetated soils in lysimeters, at different distances from the main sources of $\mathrm{SO}_{2}$ in the AOSERP study area. These determinations were made in the LS 4.2 program, and total $S$ deposition on vegetated soil in lysimeters was much greater (by factor of 3 to 8 ) than was sulphur deposition with precipitation. This needs verification. If this is borne out, a different complexion will be put on estimates of the sulphur deposition within the AOSERP study area.

2. The soil sampling every few years of the "Permanent Plots", initiated in 1976, to monitor any long-term changes of soil sulphur content and soil pH in the AOSERP study area. These replicated plots were $\mathrm{placed}$ at 17 locations, and the soils were sampled in 1976 and 1978 and the samples were analysed. Those analyses will serve as the starting point of monitoring of the soils. The monitoring of the "Permanent Plots", taken together with the results of lysimeters on the amounts of sulphur coming down, will tell in the long term how much sulphur is deposited, whether the sulphur stays in the soils, and whether the soils become acidified.

3. Little sulphur was deposited by rain and snow when the sulphur content was determined as soluble sulphate (which is the conventional method of determination the world over). However, when some of the samples from LS 4.2 and from another poject were analysed for total $S$, they gave averages of 1.5 to 2.0 times more sulphur. Therefore, it is strongly recommended that researchers analysing rain and snow from the AOSERP study area include the total $S$ method. That is, the amounts of sulphur deposition by rain and snow may not be as small as they appear. 
7. REFERENCES CITED

Abeles, F.B., L.E. Craker, L.E. Forrence, and G.R. Leather. 1971. Fate of air pollutants: removal of ethylene, sulphur dioxide, and nitrogen dioxide by soil. Sc. 173:914-916.

Abrahamsen, G., R. Hornvedt, and B. Tveite. 1976. Impacts of acid precipitation on coniferous forest ecosystems. Proc. First Int. Symp. on Acid Precip. and the Forest Ecosystem. USDA Forest Service Gen. Tech Report NE-23:991-1009.

Baker, J., D. Hocking, and M. Nyborg. 1977. Acidity of open and intercepted precipitation in forests and efffects on forest soils in Alberta, Canada. Water, Air and Soil Pollution 7:449-460.

Barret, E. and G. Brodin. 1955. The acidity of Scandinavian precipitation. Te11 us. 7:251-257.

Barrie, L.A. and J. Kovalick. 1980. A wintertime investigation of the deposition around an isolated power plant in northern Alberta. Prep. for the Alberta 0 il Sands Environmental Research Program by Atmospheric Environment Service. AOSERP Report 90. 115 pp.

Black, P.E. 1957. Interception in a hardwood stand. M.F. Thesis. University of Michigan. (Original not seen: information taken from Helvey, J.E. and J.H. Patric 1965).

Brosset, C. 1973. Air-borne acid. Ambio. 2(1-2):2-s.

Brosset, C. 1976a. Air-borne particles: black and white episodes. Ambio. 5(4):157-163.

Brosset, C. 1976b. A method of measuring air-borne acidity: its application for the determination of acid content on long-distance transported particles and in drainage water from spruces. Proc. First Int. Symp. on Acid Precip. and the Forest Ecosystem. USDA Forest Service Gen. Tech. Report NE-23:159-179.

Carlisle, A., A.H.F. Brown, and E.J. White. 1966. The organic matter and nutrient elements in the precipitation beneath a sessile oak (Quercus petraea) canopy. J. Ecol. 54:87-98.

Cox, G.L. 1975. The effect of smelter emissions on the soils of the Sudbury area. M.Sc. Thesis. University of Guelph, Guelph, Ontario.

Dean, A.G. 1966. A simple colorimetric finish for the Johnson-Nishita microdistillation for sulphur. Analyst $91(1085): 530$. 
Eaton, J.S., G.E. Likens, and F.H. Bormann. 1973. Throughfall and stemflow chemistry in a northern hardwood forest. J. Ecology $61(2): 495-508$.

Eriksson, E. 1958. The chemical climate and saline soils in the arid zone. Arid zone research, Vol. 10, Climatology, Reviews of Research. UNESCO $147-180$.

Eriksson, E. 1963. The yearly circulation of sulphur in nature. J. Geophys. Res. 68:4001-4008.

Faller, N. and K. Herwig. 1969/70. Untersuchungern ueber die $\mathrm{SO}_{2}$-oxydation in verschiedenen boeden. Geoderma 3:45-54. (Original not seen; cited by Yee at al. 1975).

Gersper, P.L. and N. Holowaychuk. 1971. Some effects of stemflow from forest canopy trees on chemical properties of soils. Ecology 52(4) $691-702$.

Ghiorse, W.C. and M. Alexander. 1976. Effects of microorganisms on the sorption and fate of sulphur dioxide and nitrogen dioxide in soil. J. Environ. Quat. 5(3):227-230.

Hart, G.E. and D.R. Parent. 1974. Chemistry of throufhfall under douglas fir and Rocky Mountain juniper. Am. Mid1. Nat. 92(1):191-201.

Helvey, J.D. and J.H. Patric. 1965. Canopy and litter interception of rainfall by hardwoods of eastern United States. Water Resources Research 1:193-206.

Hosie, P.C. 1975. Native trees of Canada. 7th ed. Canadian Forestry Service. Department of the Environment, Ottawa. $380 \mathrm{pp}$.

Johansson, 0. 1959. On sulphur problems in Swedish agriculture. Kgl. Landbr. Ann. 25:57-161.

Johnson, C.M. and H. Nishita. 1952. Microestimation of sulphur in plant materials, soils and irrigation waters. Anal. Chem. 24:736-742.

Katz, M. 1977. Sulphur and its inorganic derivatives in the Canadian environment. Publ No. NRCC 15015. Environmental Secretariat, National Research Counci1, Ottawa. pp. 21-67.

Kellogg, W.W., R.D. Cadle, E.R. Allen, A.L. Lazrad, and E.A. Martell. 1972. The sulphur cycle. Science 175(4022):587-596.

Kimmins, J.P. 1973. Some statistical aspects of sampling throughfall precipitation in nutrient cycling studies in British Columbia coastal forests. Ecology 54:1008-1019.

Longley, R.W. and B. Manz. 1978. The climatology of the Alberta 0il Sands Environmental Research Program. Prep. by Fisheries and Environment Canada, Atmospheric Environmenta Service. AOSERP Report 39. 102 pp. 
MacIntire, W.H. J.B. Young, W.M. Shaw, and B. Robinson. 1952. Nitrogen recoveries from applications of ammonium chloride, phosphate and sulfate and outgo of complementary ions in rainwater leachings through a six-foot soil-subsoil column. Soil Sco. Soc. Am. Proc. $16: 301-306$.

Madgewich, H.A.I. and T.D. Ovington. 1959. The chemical composition of precipitation in adjacent forest and open plots. Forestry $32(1): 14-22$.

Mina, V.N. 1967. Influence of stemflow on soil. Soviet Soil Science. 10:1321-1329.

Nihlgard, B. 1970. Precipitation, its chemical composition and effect on soil water in a beach and a spruce forest in south Sweden. Oikos. $21: 208-217$.

Nihlgard, B. 1971. Pedological influence of spruce planted on former beech forest soil in Scania, south Sweden. Oikos 22:302-314.

Nyborg, M. J. Crepin, D. Hocking, and J. Baker. 1977. Effect of sulphur dioxide on precipitation and on the sulphur content and acidity of soils in Alberta, Canada. Water, Air and Soil Pollution 7:439-448.

Nyborg, M. and D.R. Walker. 1977. An overview - the effects of sulphur dioxide emmissions on the acidity and sulphur content of soils. Proc. Alberta Sulphur Gas Research Workshop III. Eds. H.S. Sandhy and M. Nyborg. University of Alberta, Edmonton, Alberta. pp. 152-182.

Overrein, L.N. 1972. Sulphur pollution patterns observed: leaching of calcium in forest soils determined. Ambio. 1(4):145-147.

Parker, R.W. 1978. The influence of atmospheric sulphur emissions on nutrient return via throughfall and stemflow in three boreal forest ecosystems. M.Sc. Thesis. University of Alberta, Edmonton, Alberta. $189 \mathrm{pp}$.

Pawluk, S. and H.F. Ameman. 1961. Some forest soil characteristics and their relationship to jack pine growth. For. Sci. 7:160-172.

Pressland, A.J. 1973. Rainfall partitioning by an arid woodland (Acacia aneura F. muell.) in southwestern Queensland. Aust. J. Bot. $21: 2350-245$.

Rowe, J.S. 1972. Forest regions of Canada. Dept. of the Environment, Canadian Forest Service, Ottawa. 172 pp.

Semb, A. 1976. Measurement of acid precipitation in Norway. Proc. First Int. Symp. on Acid Precip. and the Forest Ecosystem. USDA Forest Service Gen. Tech. Report NE-23:119-129. 
Smith, K.A., J.M. Bremner, and M.A. Tabatabai. 1973. Sorption of gaseous atmospheric pollutants by soils. Soil Sci. 116:313-319.

Strosher, M.M. 1978. Ambient ion quality measurements in the AOSERP study area, 1977. Prep. for Alberta $0 i 1$ Sands Environmental Research Program by Pollution Control Division, Alberta Environment. Project ME 2-1.

Summers, P.W. and B. Hitchon. 1973. Source and budger of sulfate in precipitation from central Alberta, Canada. J. Air Pollution Control Assoc. 23(3):194-199.

Summers, P.W. and D.M. Whelpdale. 1976. Acid precipitation in Canada. Proc. First Int. Symp. on Acid Precip. and the Forest Ecosystem. USDA Forest Service Gen. Techn Report NE-23:411-421.

Tabatabai, M.A. and J.M. Bremner. 1976. An alkaline oxidation method for determination of total sulphur in soils. Soil Sci. Soc. Amer. Proc. 34:62-65.

Tamm, C.0. and T. Troedsson. 1955. An example of the amounts of plant nutrients supplied to the ground in road dust. 0ikos 6:61-70.

Tamm, C..0., G. Wiklander, and B. Popovic. 1976. Effects of application of sulphuric acid to poor pine forests. Proc. Int. Symp. on Acid Precip. and the Forest Ecosystem. USDA Forest Service Gen. Tech. Report NE-23:1011-1026.

Terraglio, F.P. and R.M. Manganelli. 1966. The influence of moisture on the absorption of atmospheric sulphur dioxide by soil. Air and Water Pollut. Int. J. 10:783-791.

Thomas, W.A. 1969. Accumulation and cycling of calcium by dogwood trees. Ecol. Monogr. 39:101-120.

Tollefson, E.L. 1972. Second annual quarterly meeting Canadian natural gas processor association, Edmonton, Alberta. (Original not seen; information taken from Nyborg and Walker 1977).

Voigt, G.K. 1960. Alteration of the composition of rainwater by trees. Am. Mid1. Nat. 63:321-326.

Walker, D.R. 1969. Sulfur in precipitation in Central Alberta. Can. J. Soi1 Sci. 49:409-410.

Wiklander, L. 1975. The roles of neutral salts in the ion exchange between acid precipitation and soil. Geoderma 14:93-105.

Yee, M.S., H.L. Bohn, and S. Miyamoto. 1975. Sorption of sulphur dioxide by calcareous soils. Soil Sci. Amer. Proc. 39:268-270. 


\section{8. $\quad$ APPENDICES}

8.1 THE TOTAL PRECIPITATION FOR EACH MONTH RECORDED AT EACH OF THE FIELD SITES OVER THE SUMMERS OF 1976 AND 1977. 


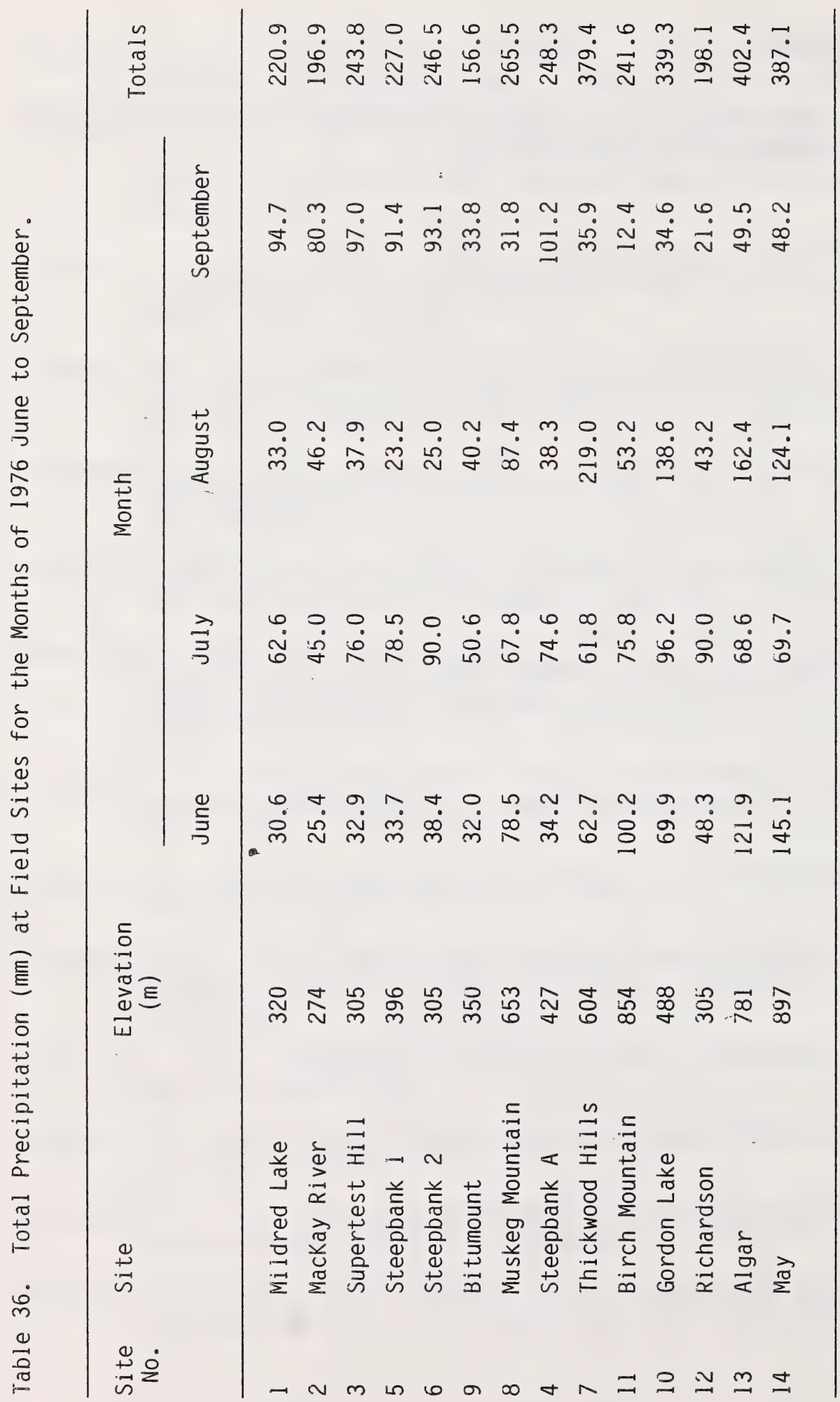




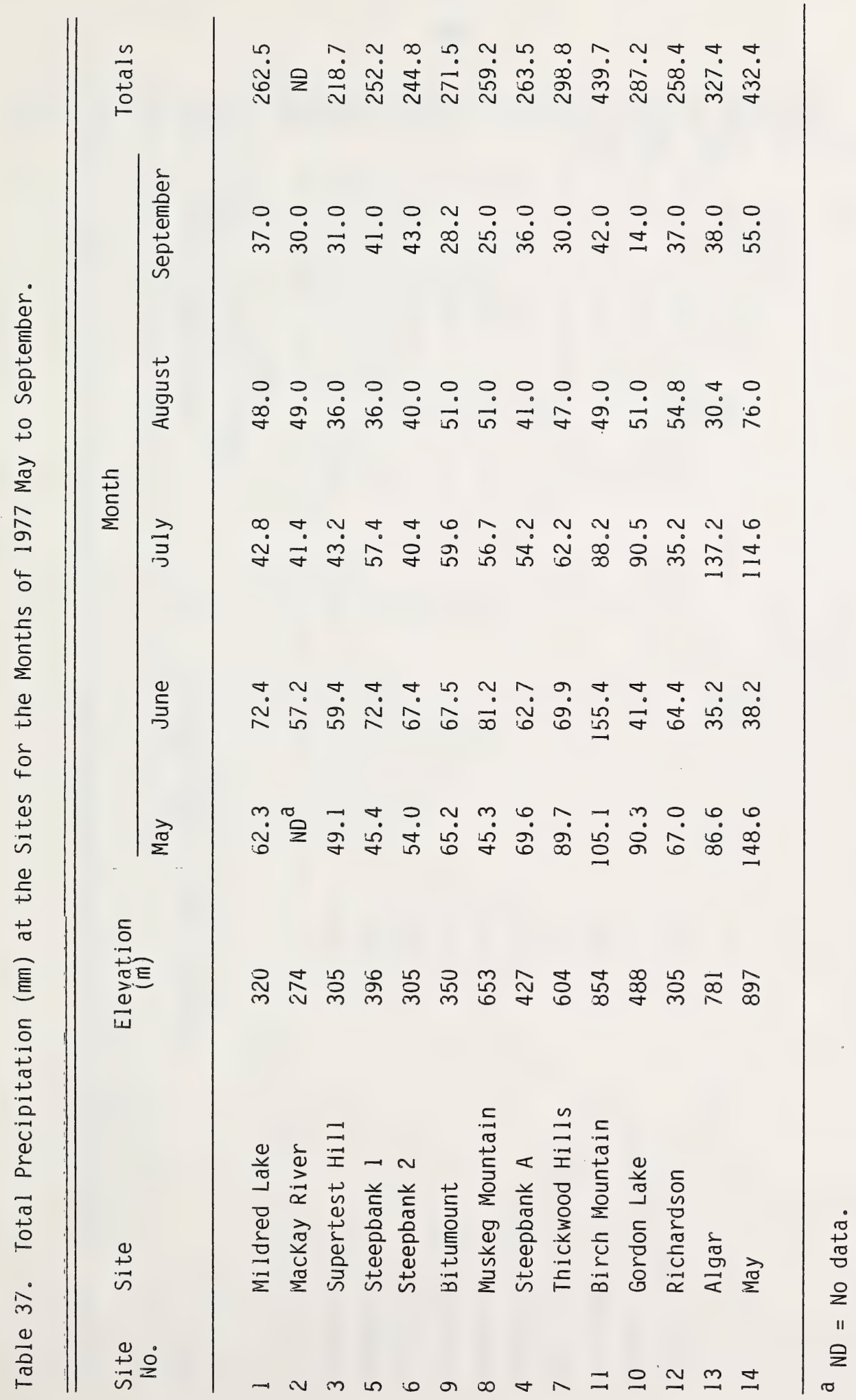


100

8.2 SULPHATE SULPHUR DEPOSITION IN RAIN MEASURED AT EACH OF THE FIELD SITES IN 1975, 1976, AND 1977. 
101

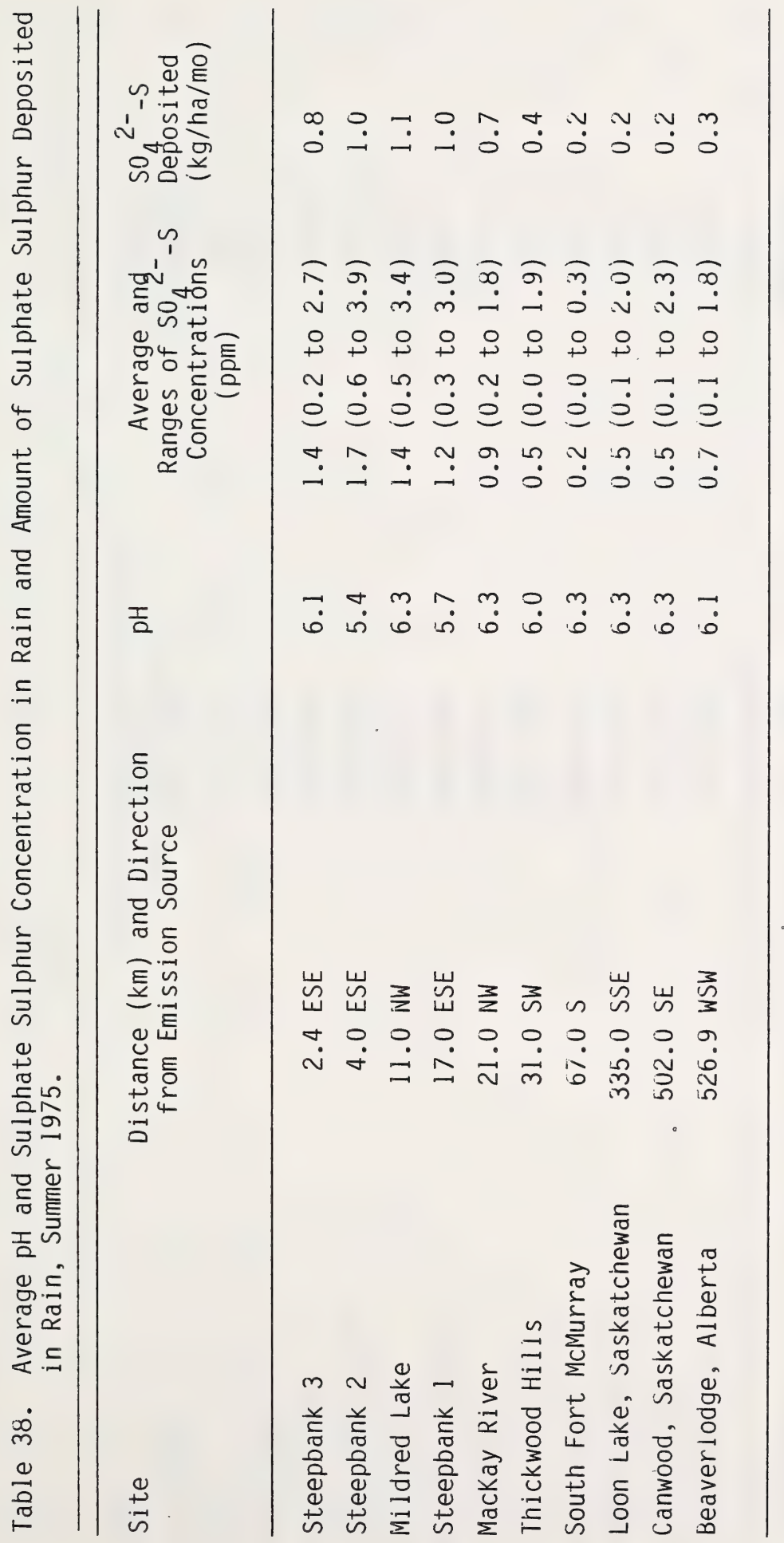




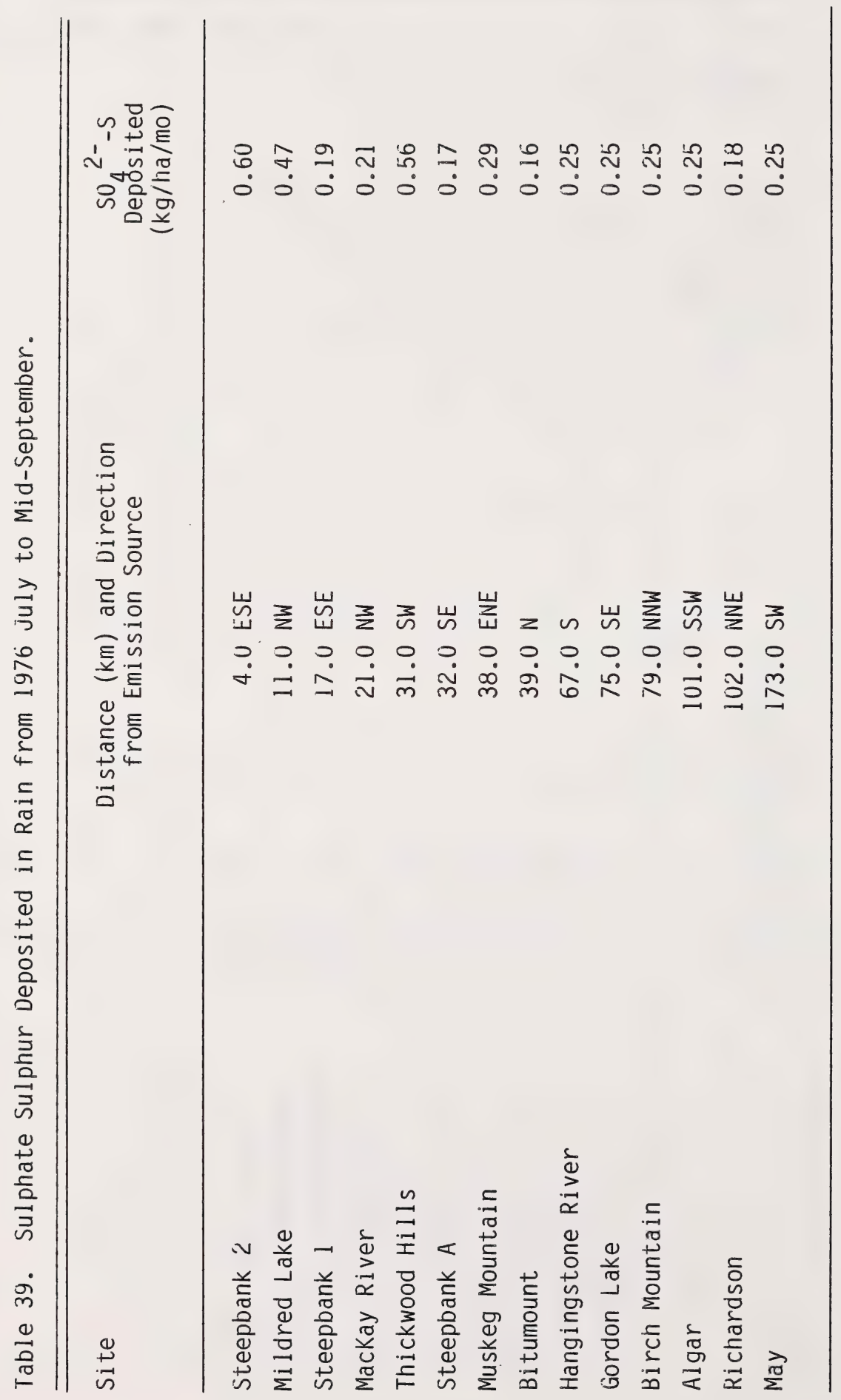




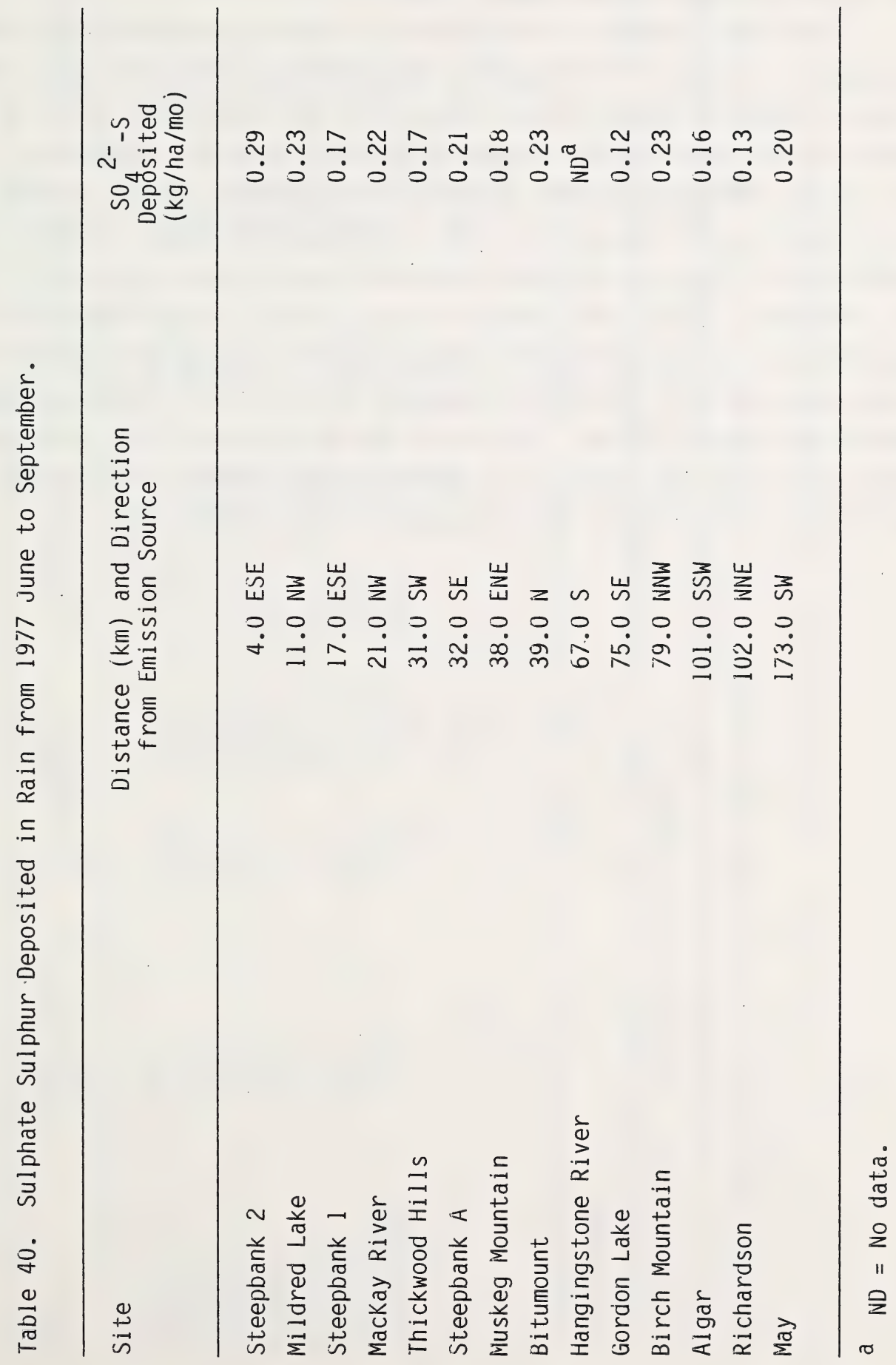


8.3 DISTRIBUTION OF RAINFALL UNDER TREMBLING ASPEN AND JACK PINE STANDS USED IN THE NUTRIENT CYCLING STUDY, 1976.

Net precipitation is the portion of incident precipitation reaching the ground in the form of throughfall and stemflow. Interception is the portion of incident precipitation retained by the tree canopy which is absorbed by the trees and/or evaporated directly into the atmosphere. This is equal to the difference between incident precipitation and net rainfall. On several occasions at the control site, jack pine throughfall exceeded the incident rain. This has also been noted by several other researchers (Voigt 1960, Pressland 1973). This could be due to rain at an oblique angle being caught directly by the throughfall gauges without passing through the canopy. On the occasions when throughfall exceeded incident rain, the percentage stemflow was unusually high. This could be due to wind driven rain impinging directly onto the tree trunks to a greater extent. Black (1957) noted that stemflow was greater during storms accompanied by a high wind. 
105

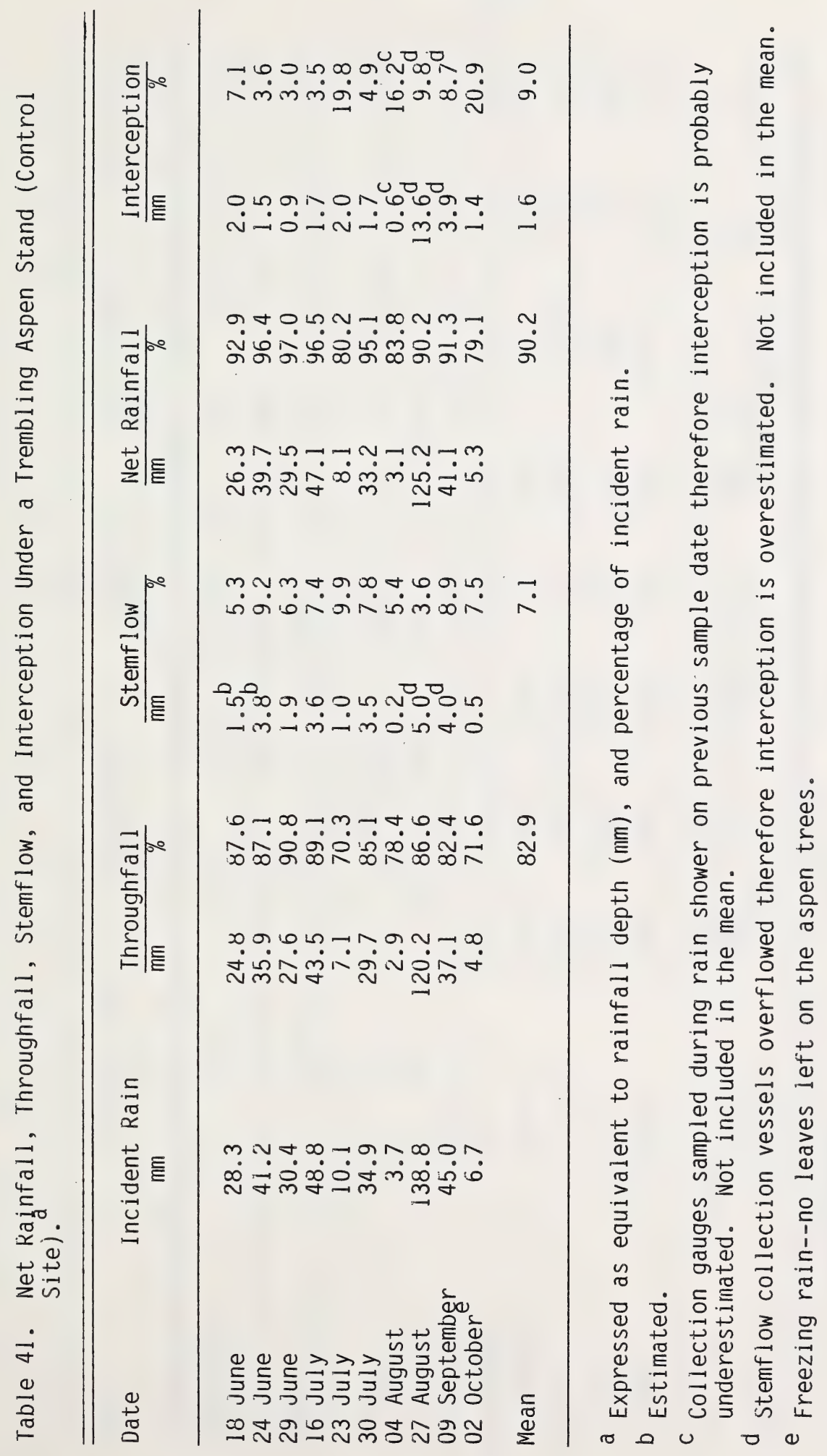




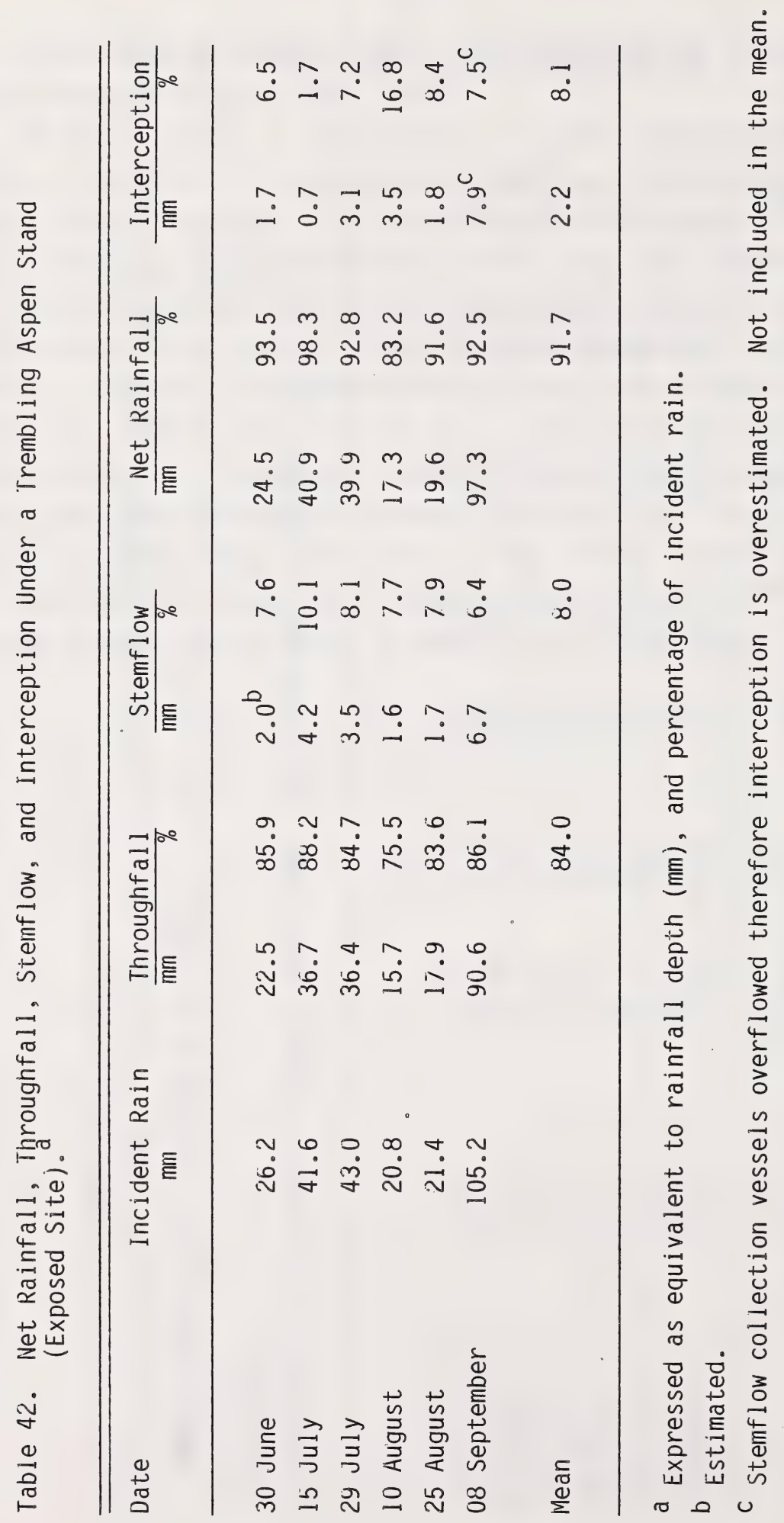




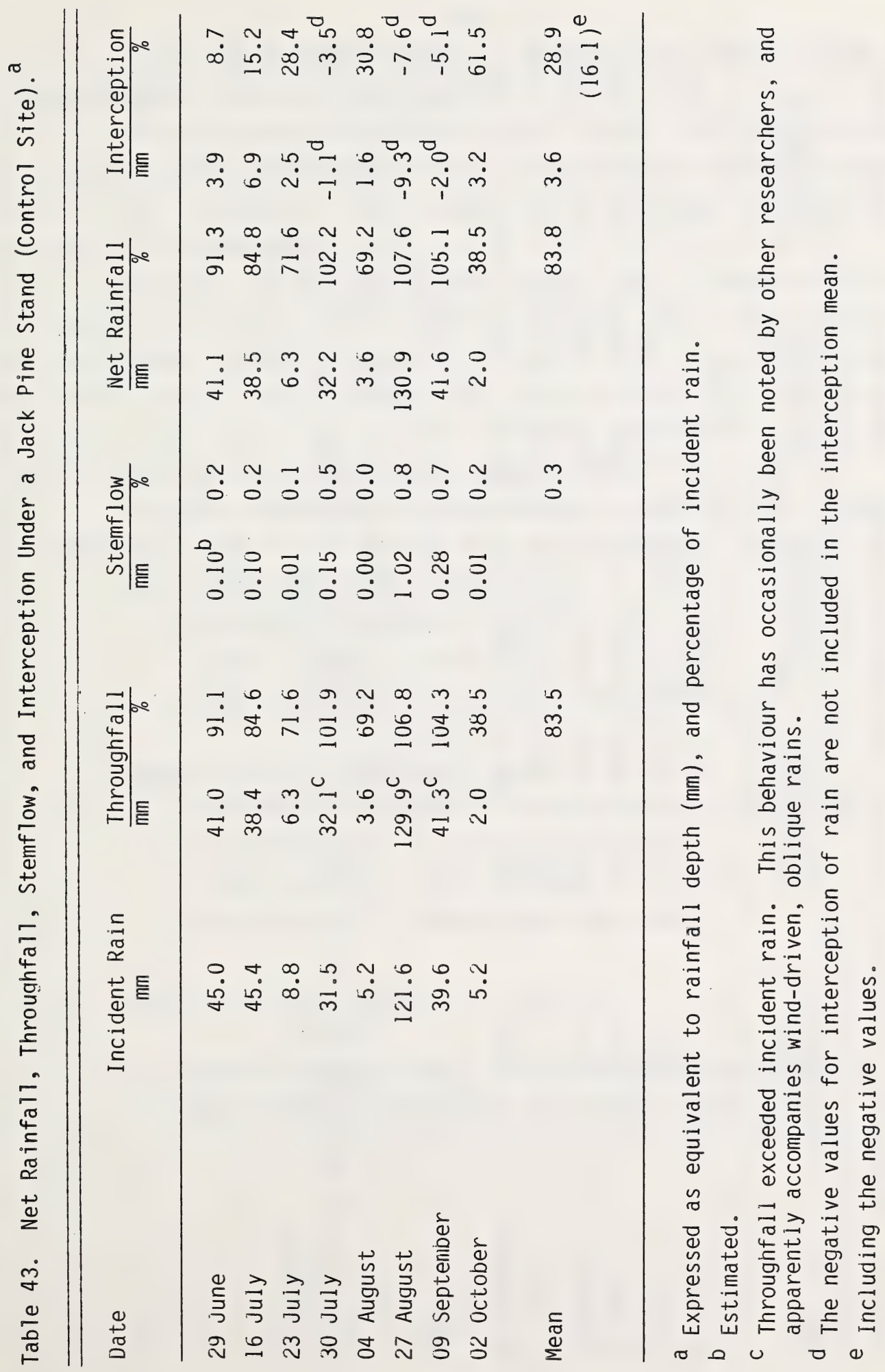




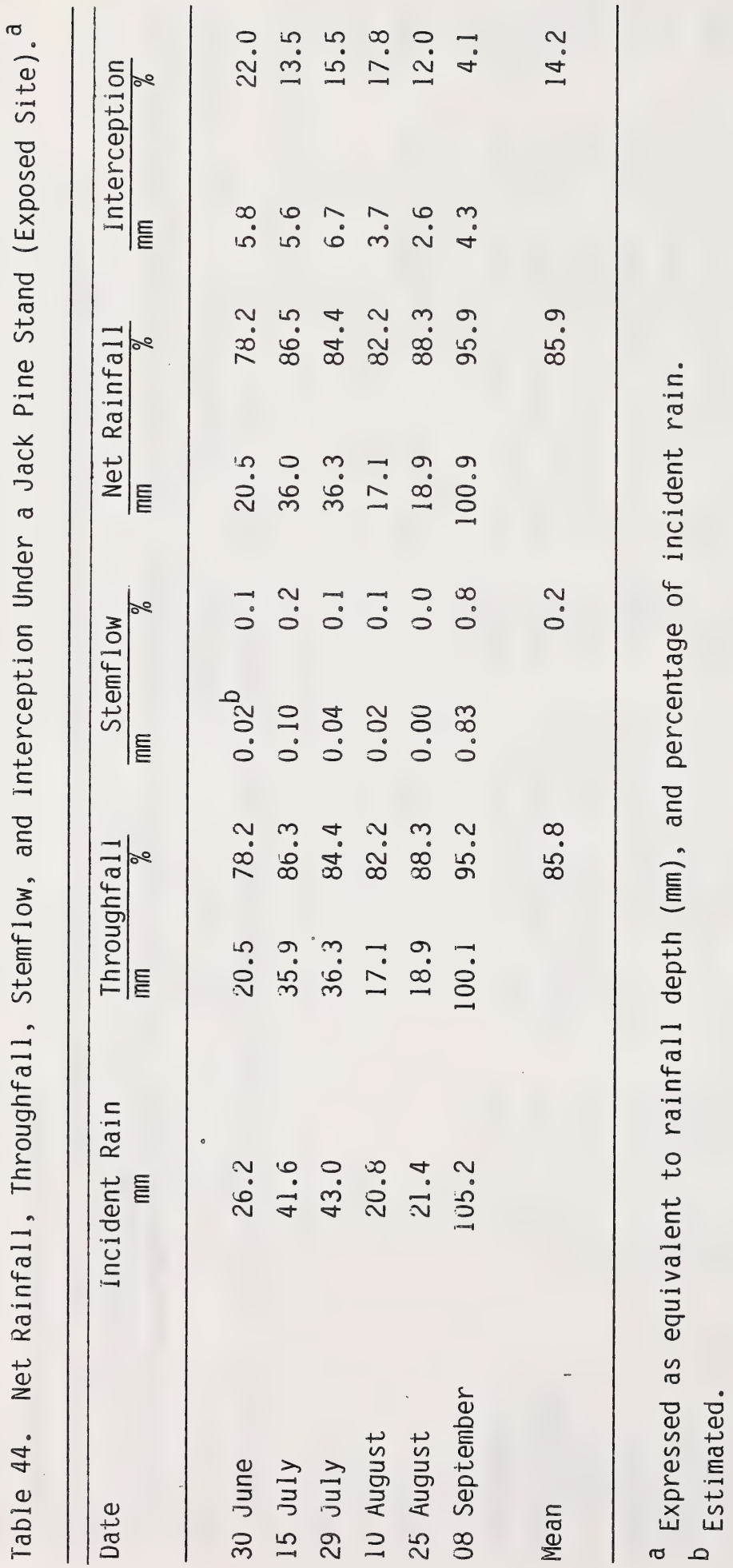


8.4 ACIDITY AND NUTRIENT CONTENT OF INCIDENT RAIN, AND JACK PINE, AND TREMBLING ASPEN THROUGHFALL AND STEMFLOW

The quantities of nutrients $(\mathrm{kg} / \mathrm{ha})$ in each rain type were calculated by multiplying the concentration values in $\mathrm{mg} / \mathrm{L}$ by the volume of each rain type in L/ha. Throughfall data are means of 20 replicates and stemflow data are means of 10 replicates.

The amount of sulphate sulphur removed from the tree canopies by rain and deposited on the soil was calculated using the sums of the amounts of sulphate sulphur during the season in throughfall and in stemflow (Tables 17 , 46 , and 47), as well as in incident rain (Tables 46 and 47 ). The value obtained at the exposed site was then divided by the control site to give the deposition percentage increase at the exposed site.

Using the summed values for throughfall, stemflow, and incident rain obtained from Tables 17, 46, and 47, the calculation is as follows:

Control site with values in $\mathrm{kg} \mathrm{S} \mathrm{ha}-1$

Throughfall + stemflow - incident rain

$=0.787+0.095-0.336$

$-0.564 \mathrm{~kg} \mathrm{~S} \mathrm{ha}{ }^{-1}$ removed from tree canopy.

Exposed site with values $\mathrm{kg} \mathrm{S}$ ha

Throughfall + stemflow - (incident rain at exposed site

- incidental rain at control site)

$=0.860+0.374-(0.733-0.336)$

$=0.837 \mathrm{~kg} \mathrm{~S} \mathrm{ha}^{-1}$ removed from tree canopy.

Therefore, $\underline{0.837-0.564} \times 100=53 \%$ more $S$

$$
0.564
$$

removed from tree canopy and deposited on the soil at the exposed site as compared to the control site. 


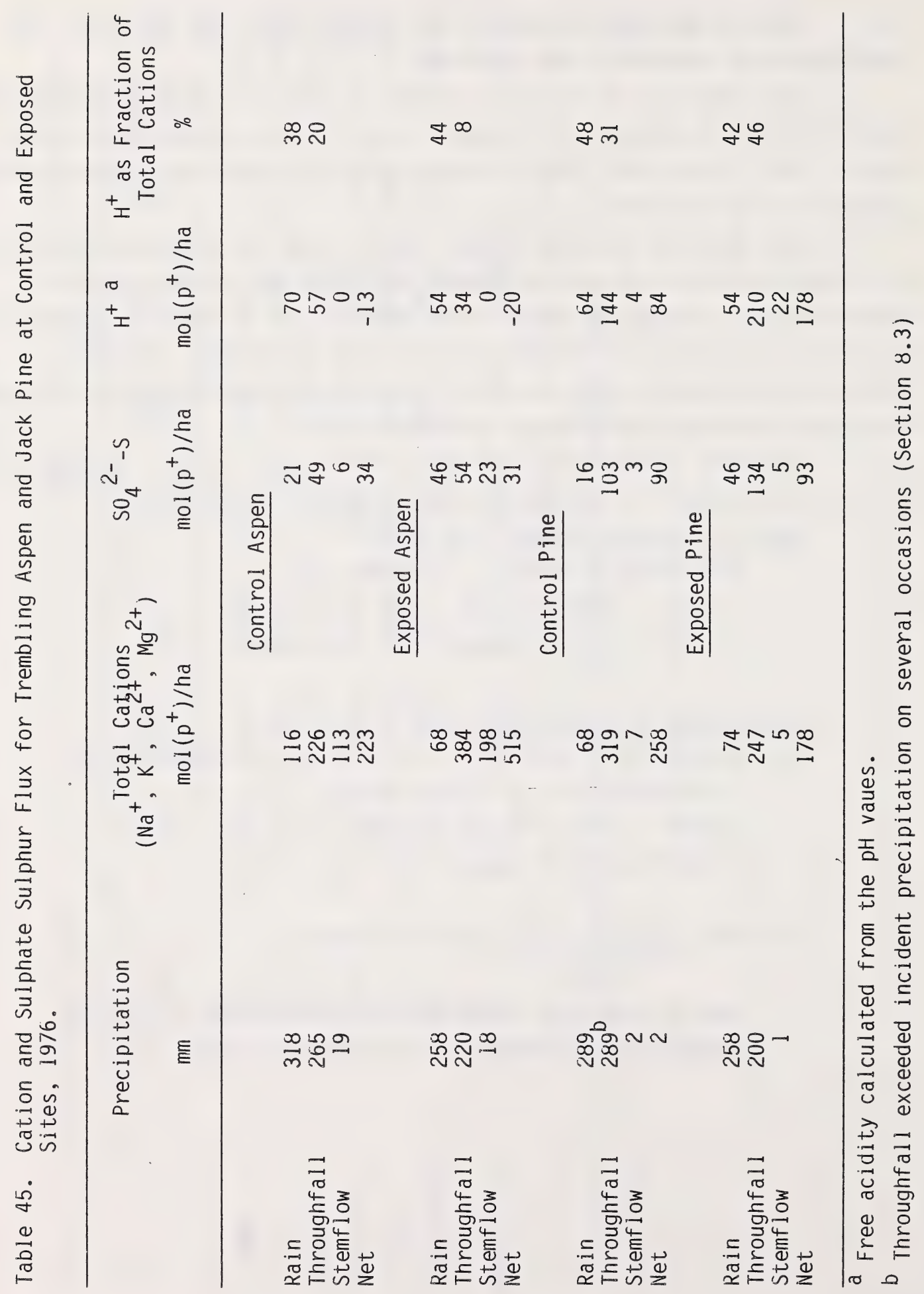




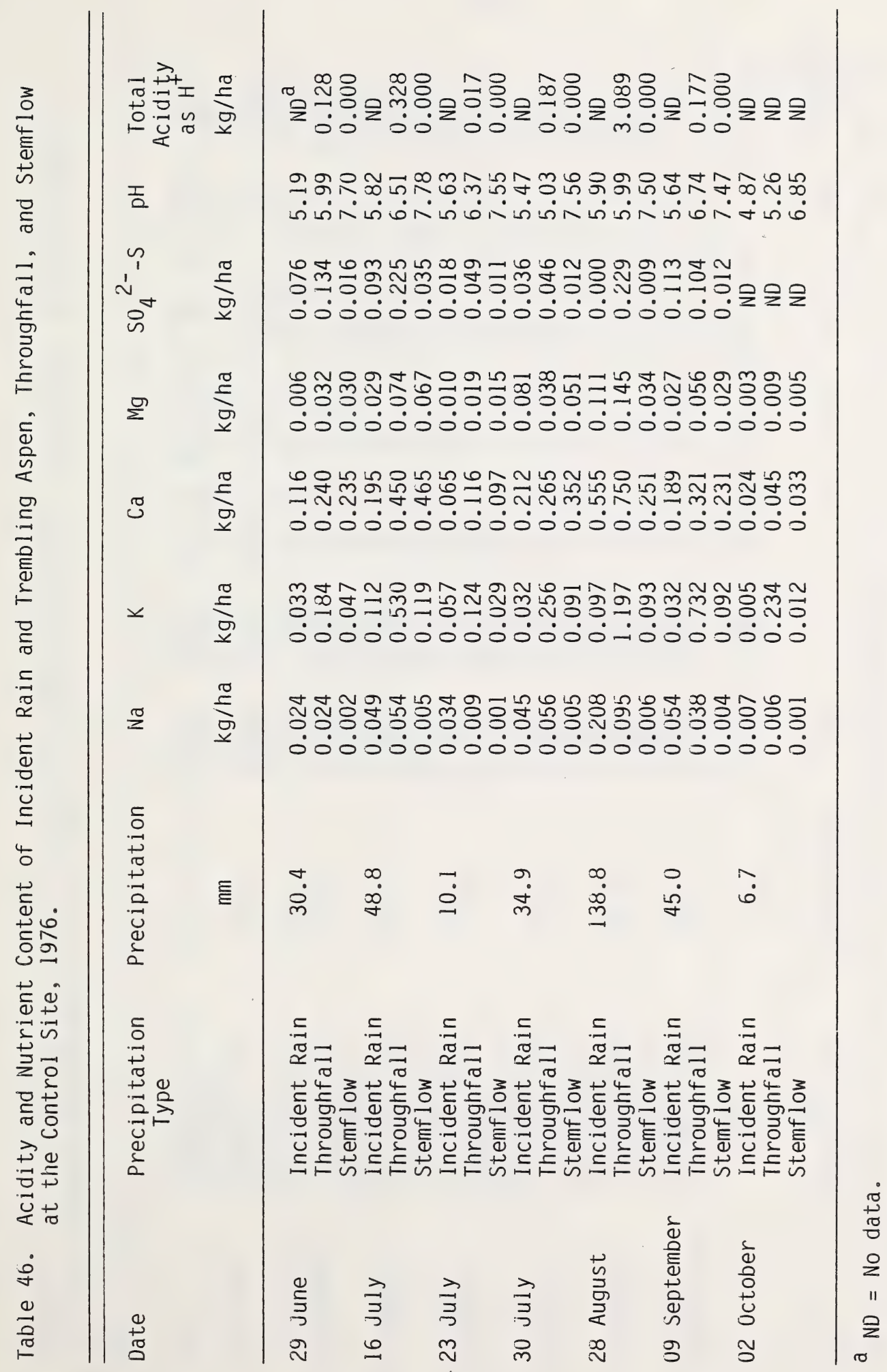




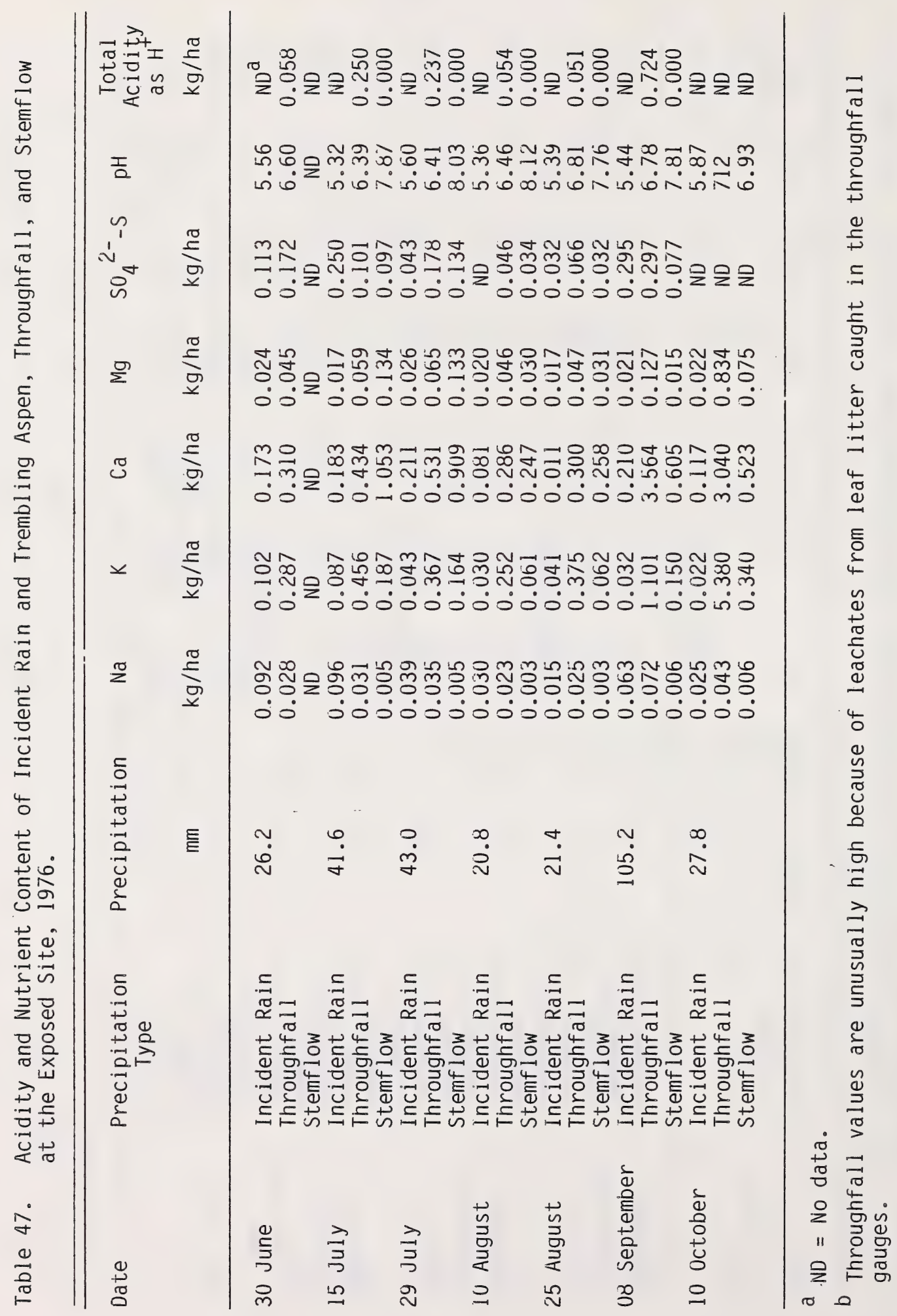




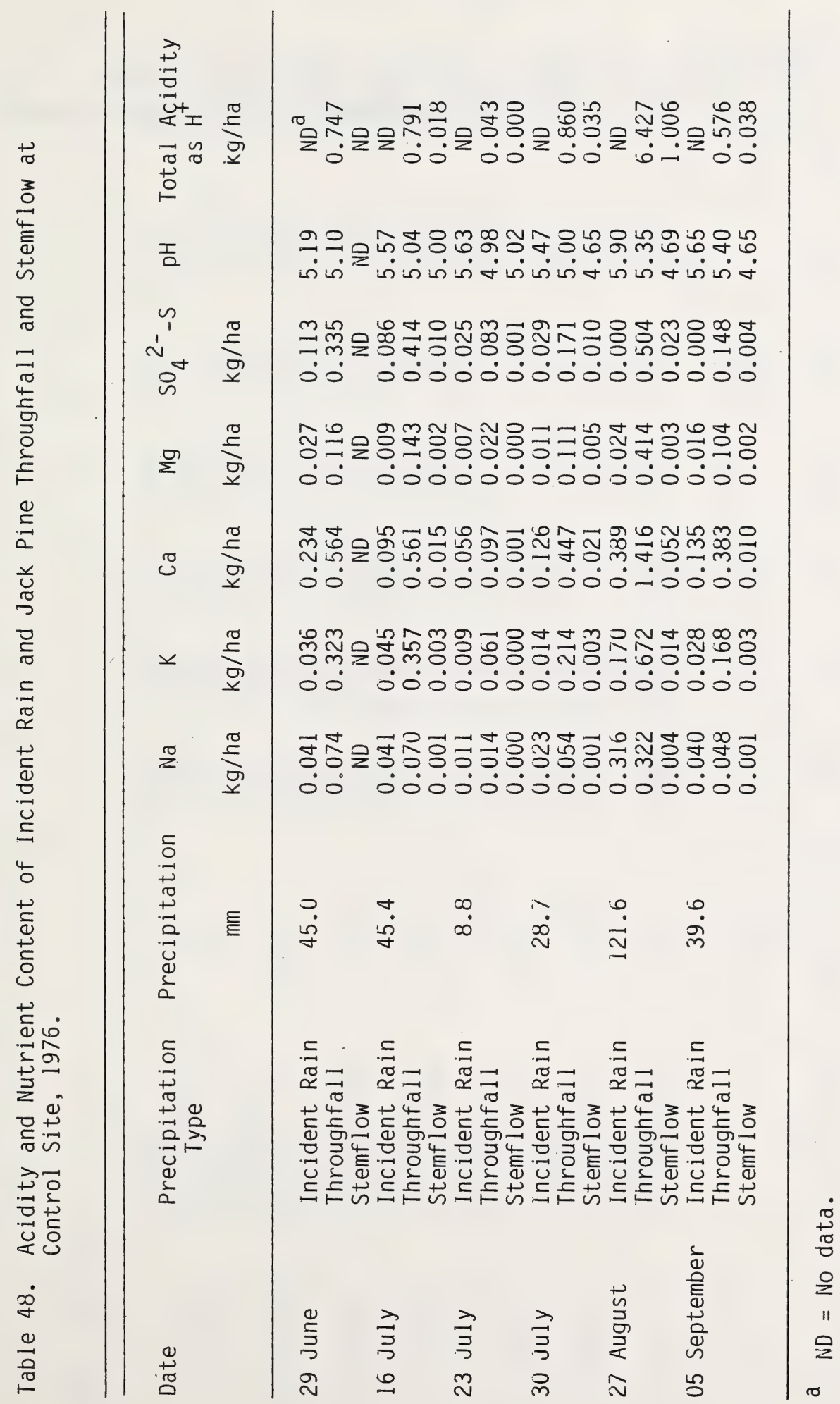


号 ம்

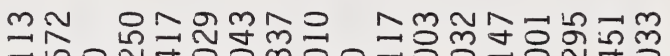

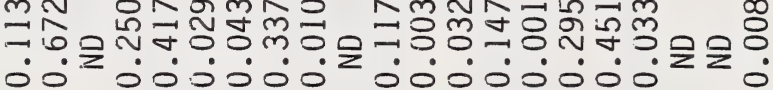

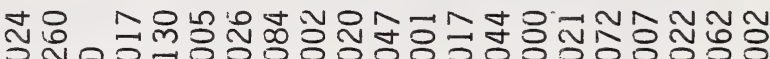

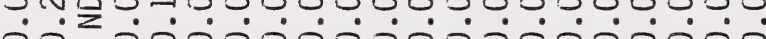

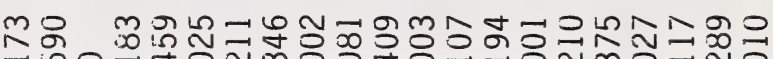
-io

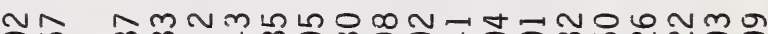

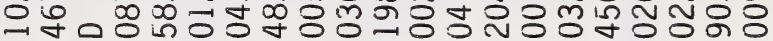
0

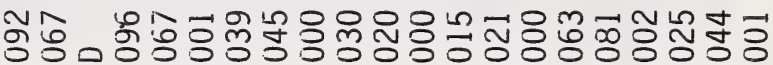
0.

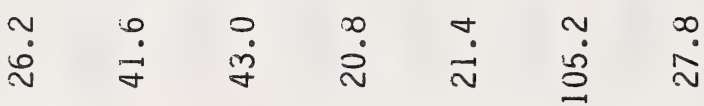

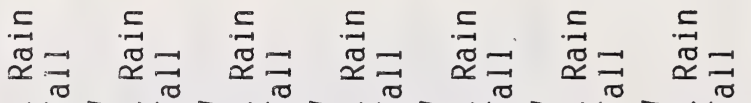

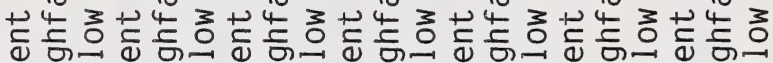

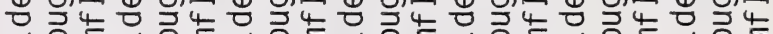

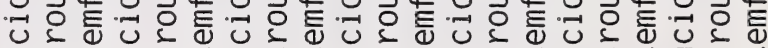

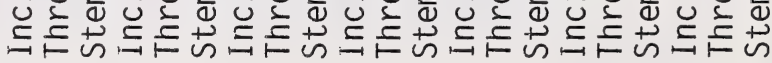

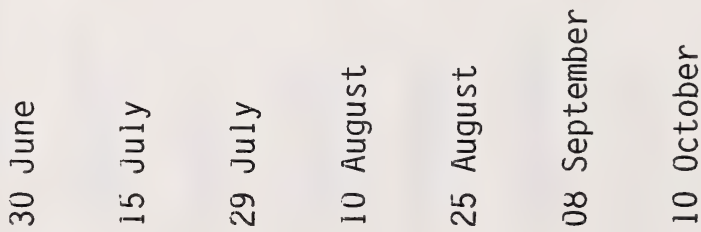


115

8.5 ACIDITY AND SULPHATE SULPHUR CONCENTRATION IN THROUGHFALL AND STEMFLOW OF DIFFERENT TREE SPECIES. 


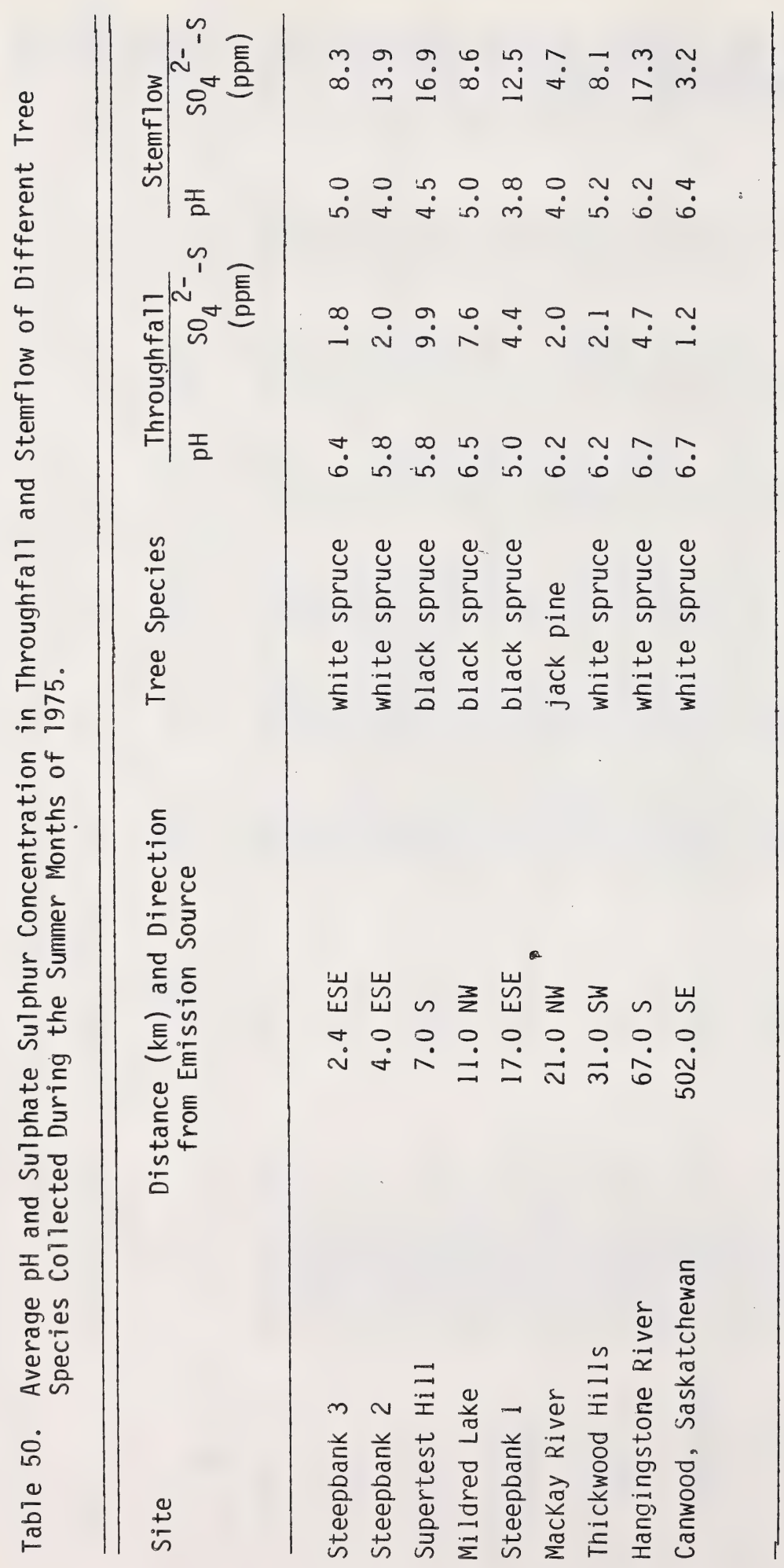




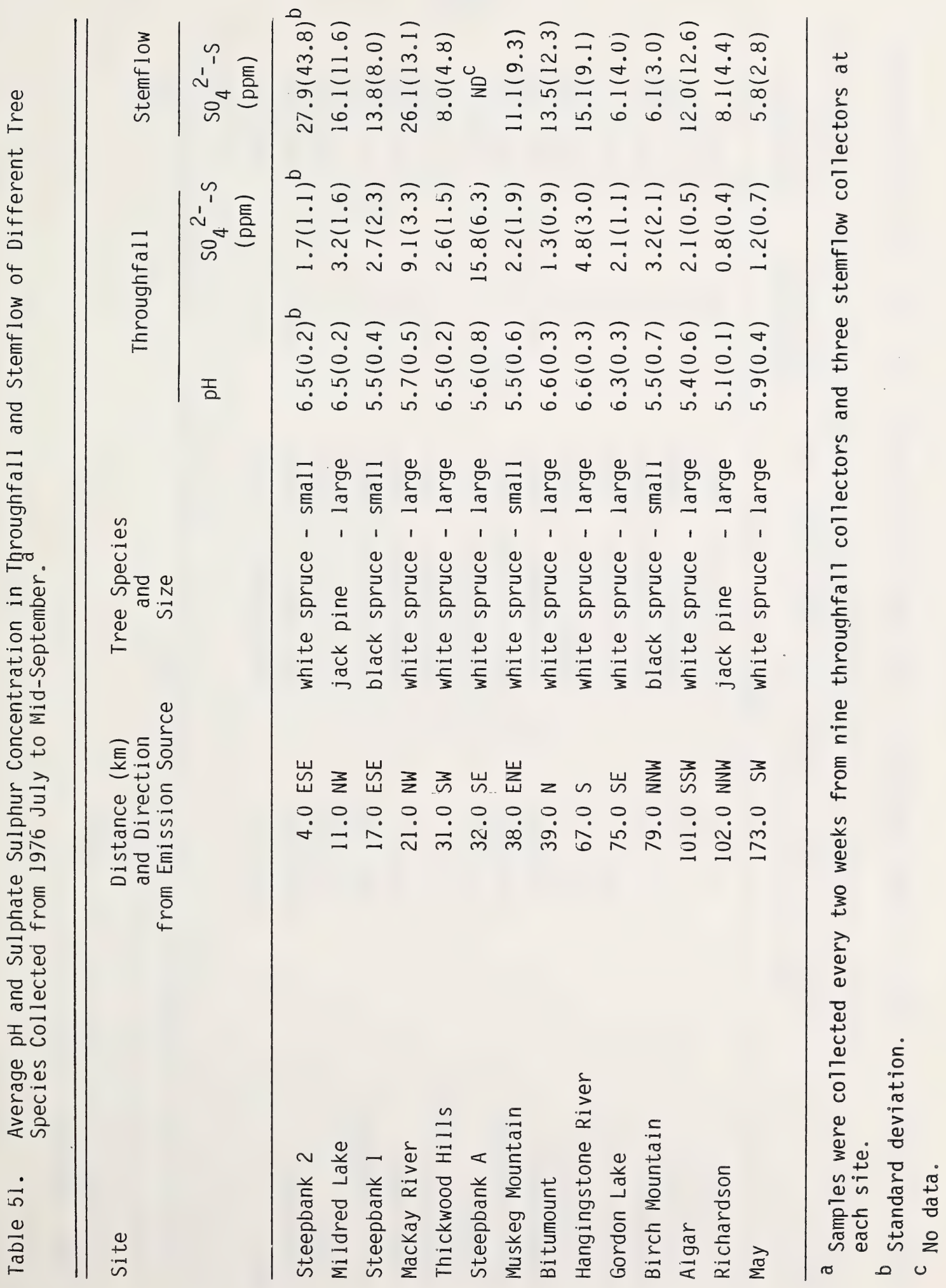




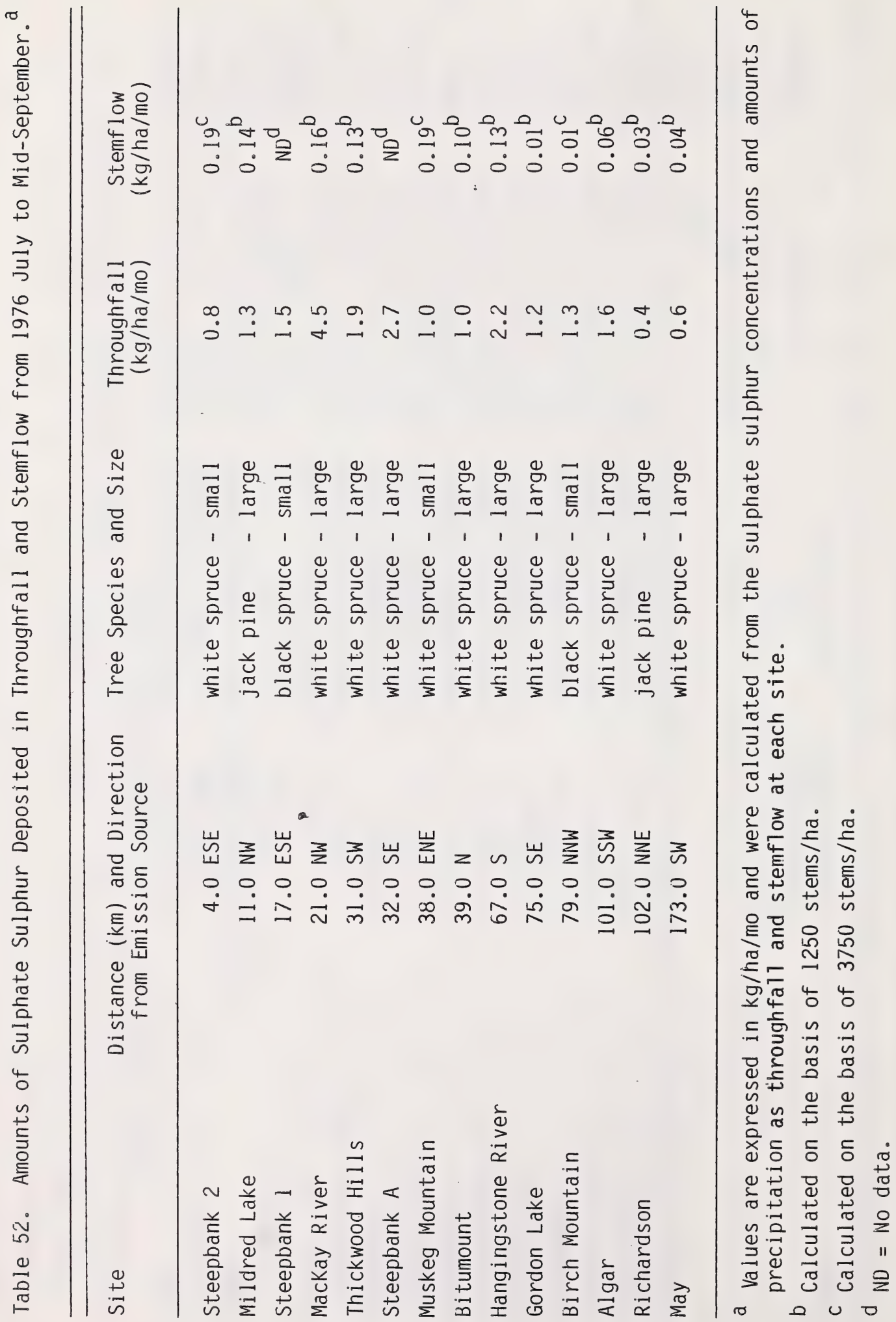


8.6 ABSORPTION OF SULPHUR DIOXIDE BY SULPHATION DISCS 


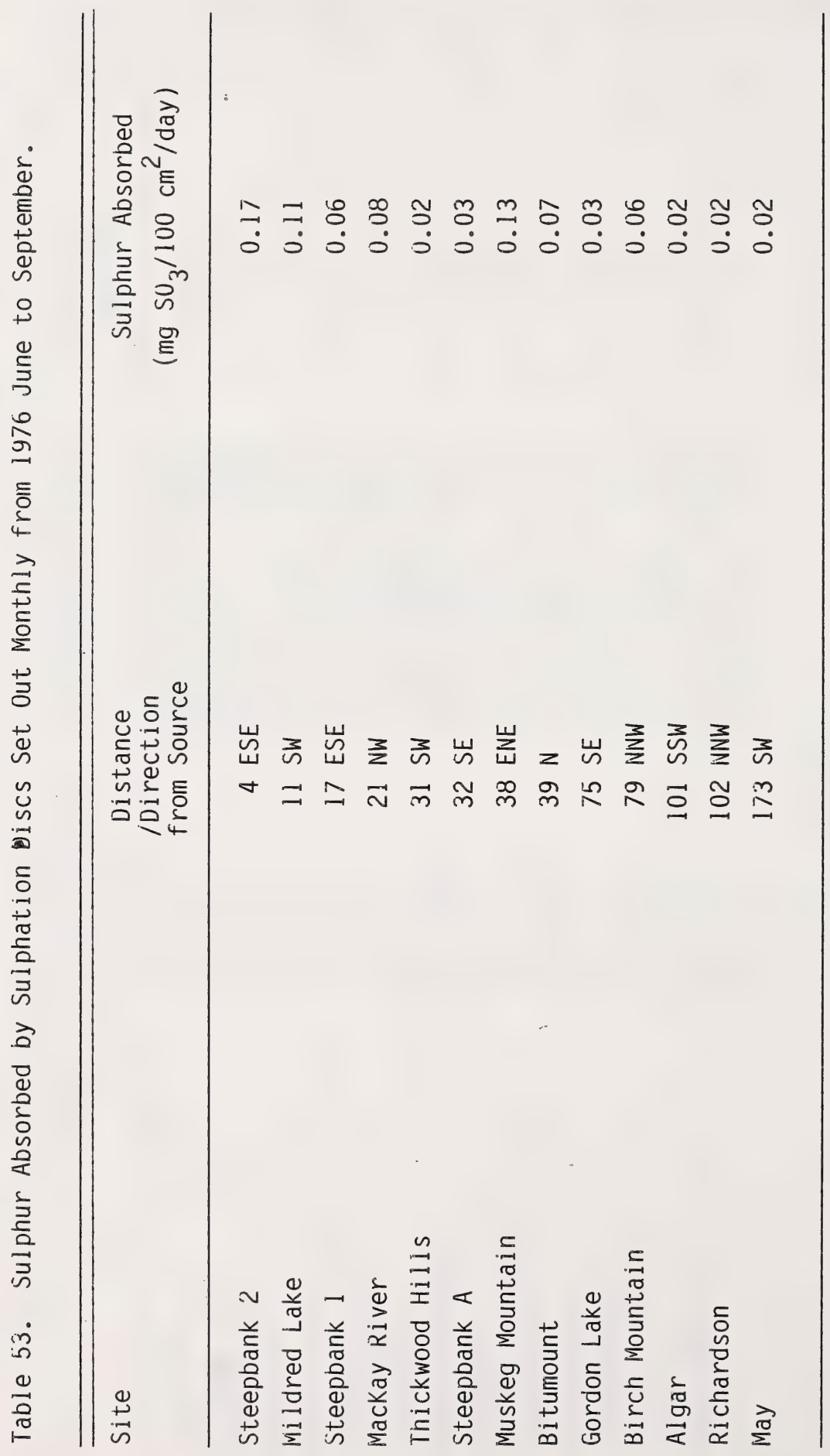




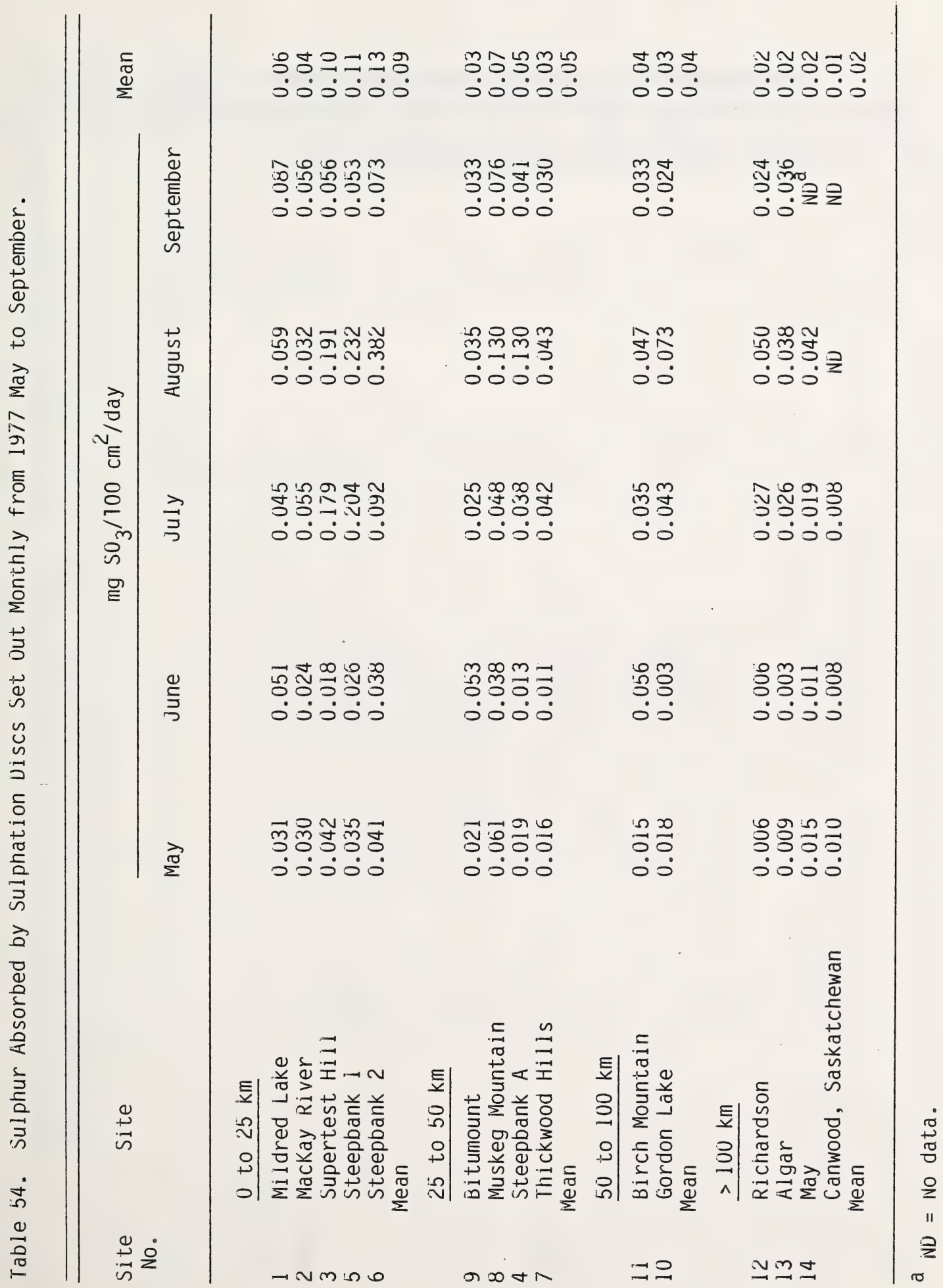


8.7 REGRESSION ANALYSIS OF SOIL FREE ACID, SULPHATE SULPHUR, AND TOTAL SULPHUR CONCENTRATIONS VERSUS DISTANCE FROM A SULPHUR DIOXIDE EMISSIONS SOURCE AND ESTIMATED AVERAGE SULPHUR DIOXIDE CONCENTRATIONS 
סे

$\mid$

مٍ

는

जิ ह.ำ

Q $\frac{\bar{y}}{+}+$

ס

를

इ

n.

$+20$

+ I $\cong \frac{0}{5}$

등ำ

t)

๙

\pm -

过苛

든

늘

ᄃ 등 따

음 흥

당

뭉ㄷㅇ

웓

전

등 읃

능

4 ज

$\sim \pi$ 的

$\sim+0$

즈은

它 읃 v

ᄃํㅡㄹ

in 1

थิ ?

ธัర

뜸ำ

น

$\frac{0}{\frac{0}{10}}$
宁

() 어

(2) ช

তิ

(4)

ঠे

点

만.

즘

艺 4

$\stackrel{0}{2}$

$\stackrel{2}{2}$

กี ำ ำ

ำ

范

능

ڤ્ત

式

홈

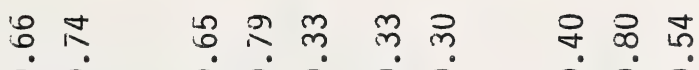

$\dot{0} 0 \dot{0} 00000000$

ญ.

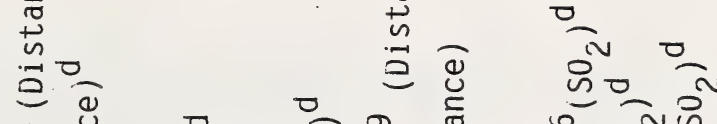

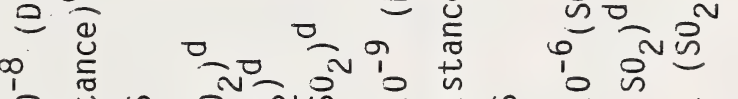

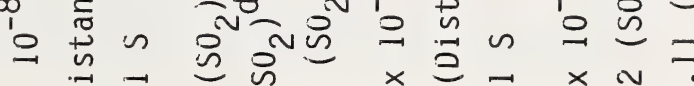

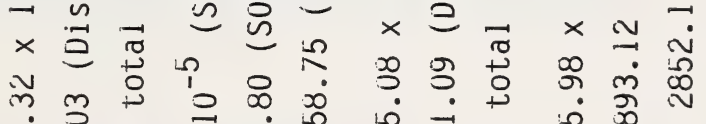

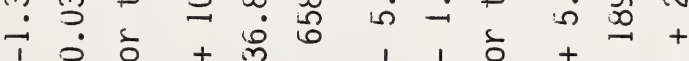

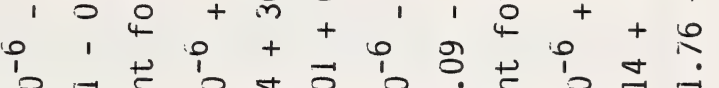

అ

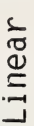

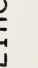

茫

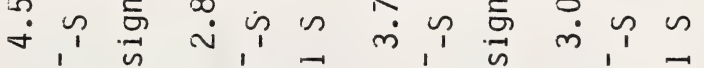

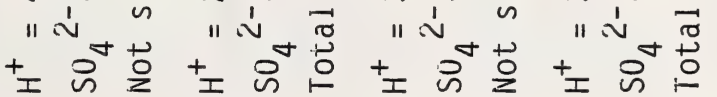

눙
흘
ஸे

$+\sum_{0}$
$\stackrel{0}{0}$
$\varnothing$

\begin{tabular}{l|l}
$\overrightarrow{0}$ & $\frac{\overrightarrow{0}}{0}$ \\
n & ज
\end{tabular} $\dot{\bar{\alpha}}$
$\frac{\Sigma}{2}$
$\frac{1}{\sigma}$

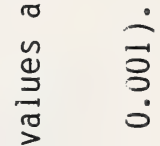

.

T⿱亠

워

1 ర్

ㄷํㅇ

प्रे ज

总 ‡

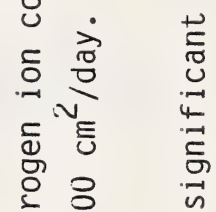

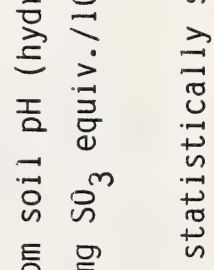

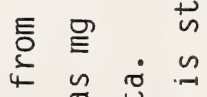

¿ 0 \%

夏芯

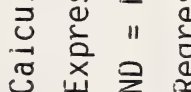

r 000 
8.8 THE SULPHUR CONTENT AND PH OF LYSIMETER SOILS SET OUT IN THE FIELD FROM JULY 1976 TO AUGUST 1978. 


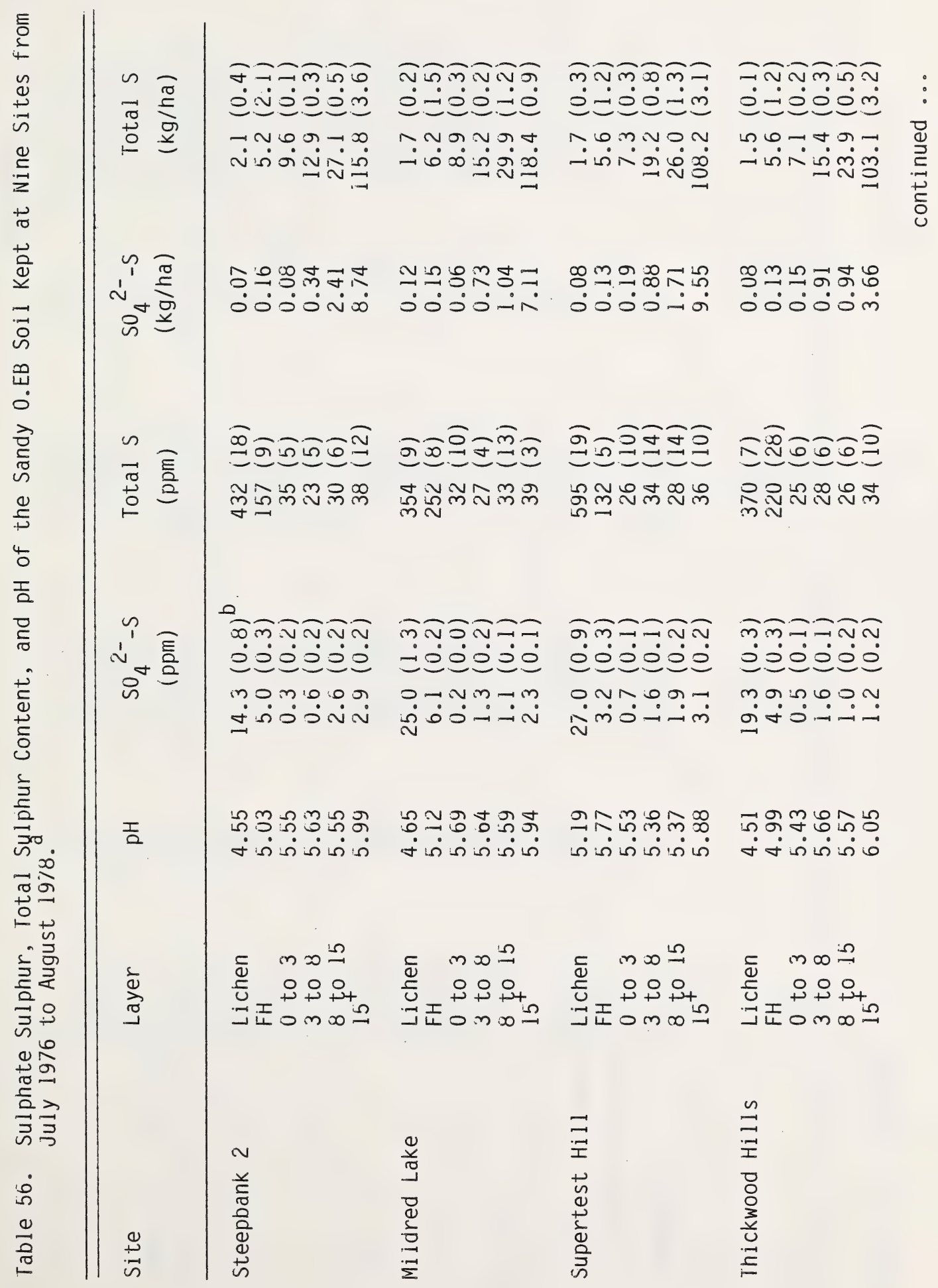




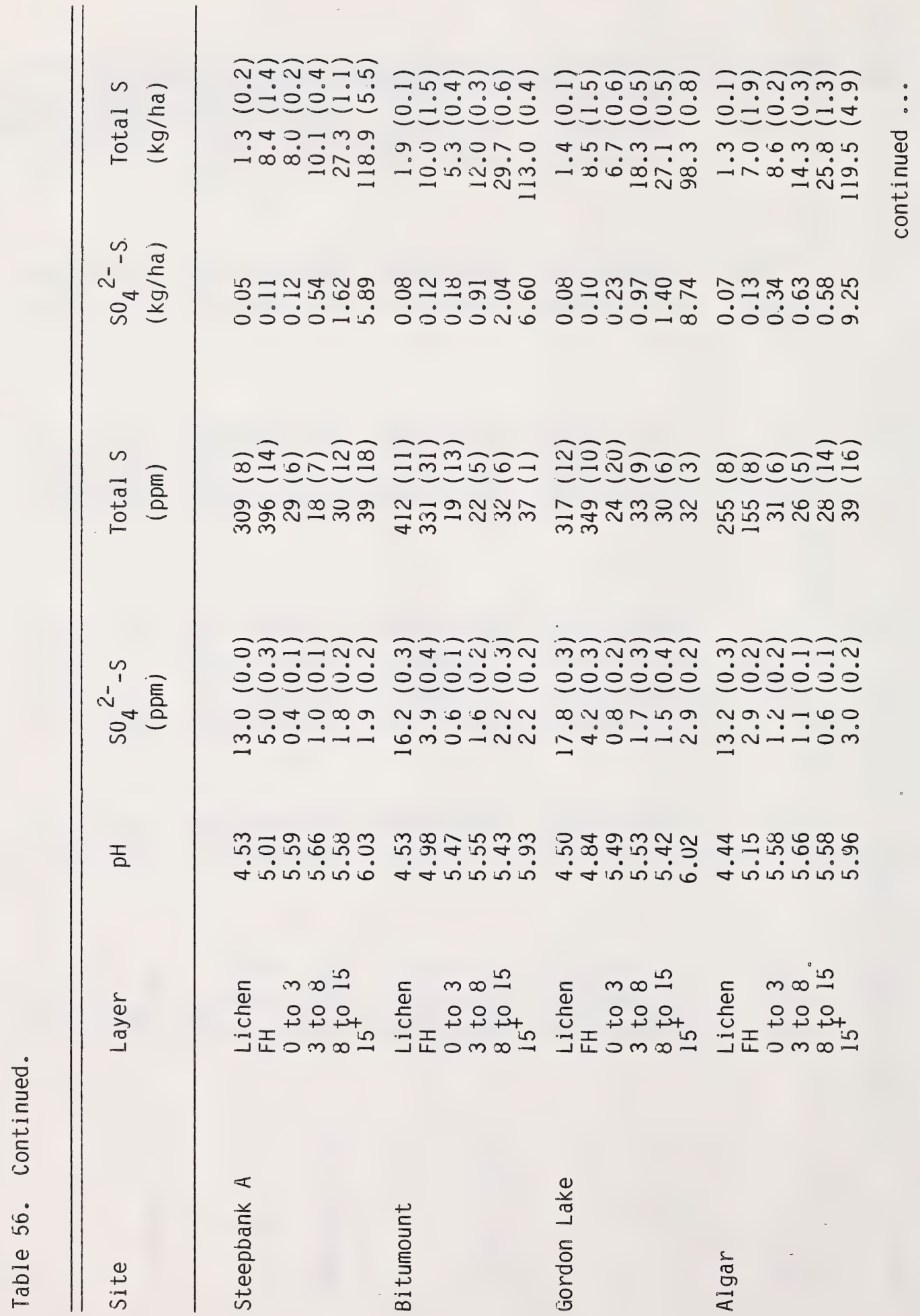




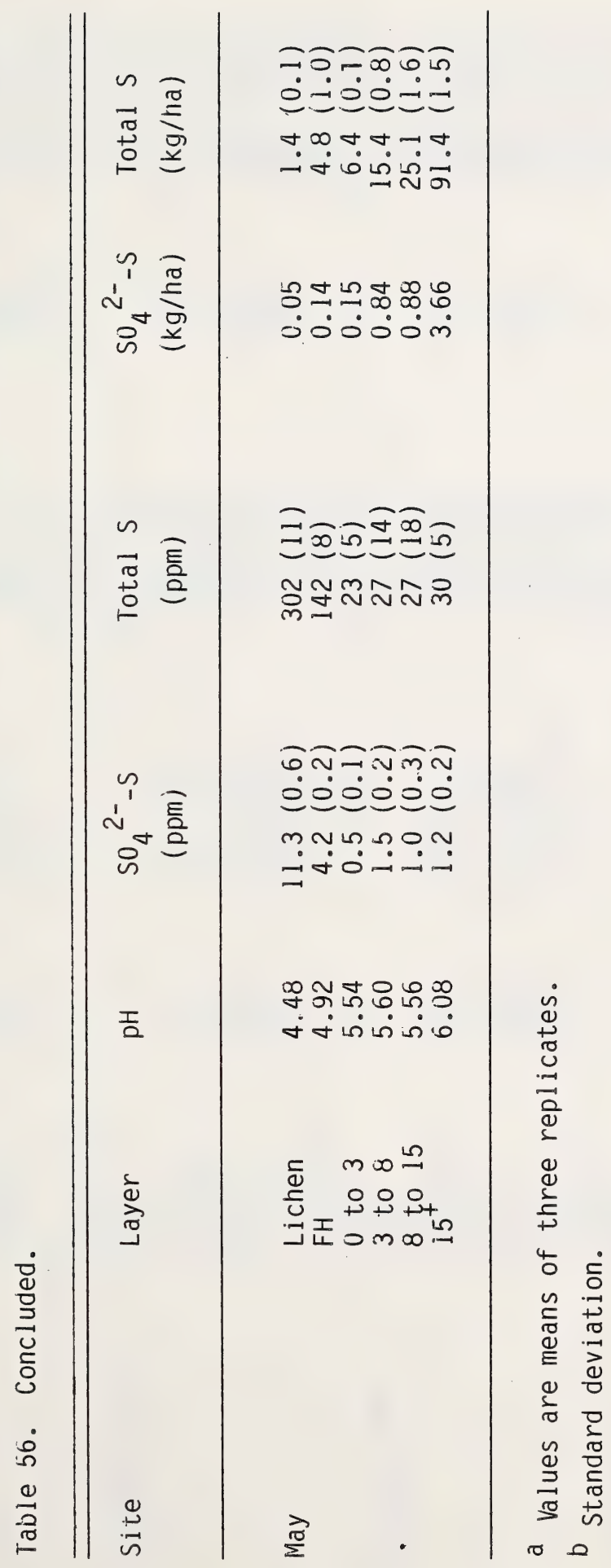




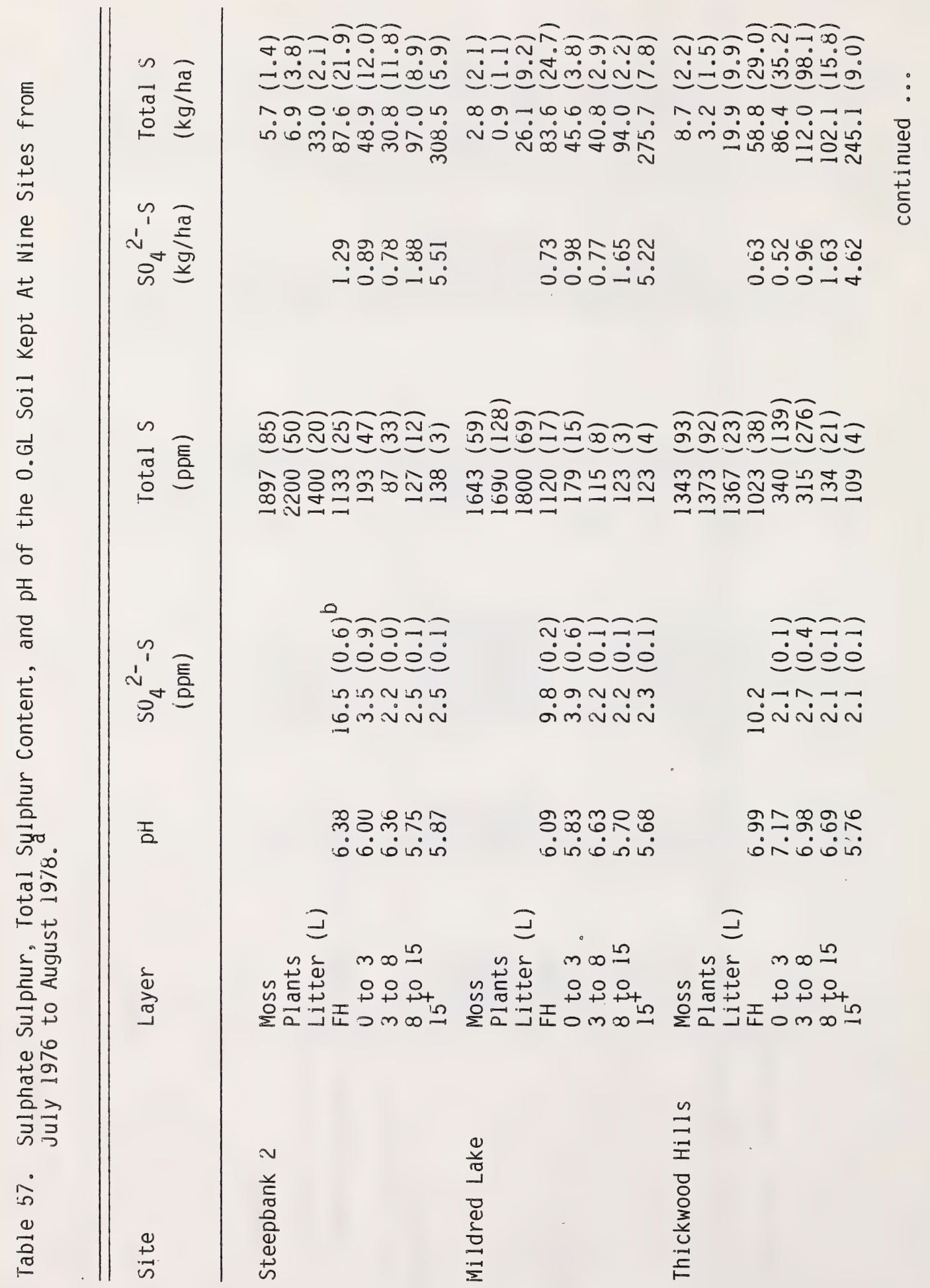




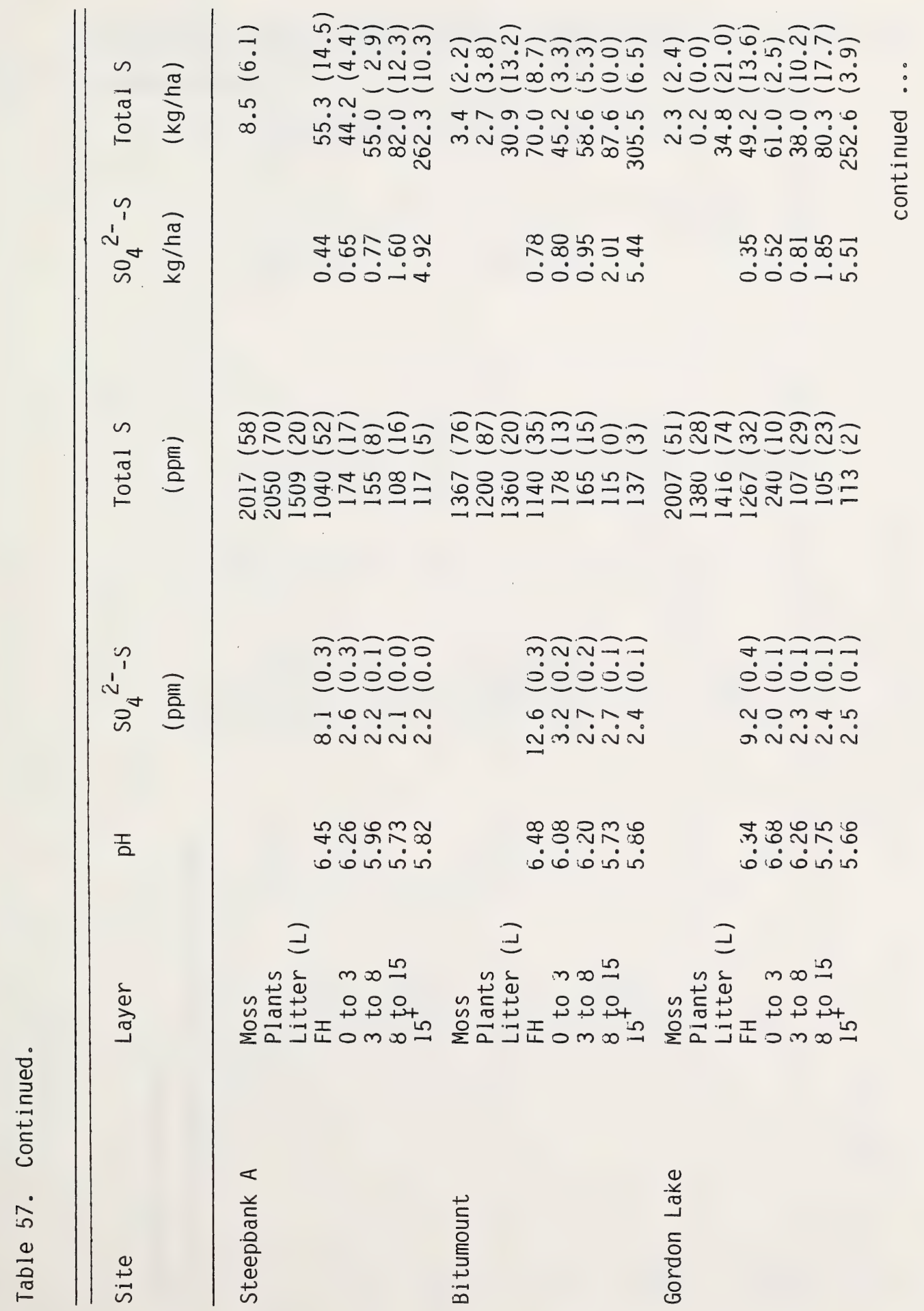




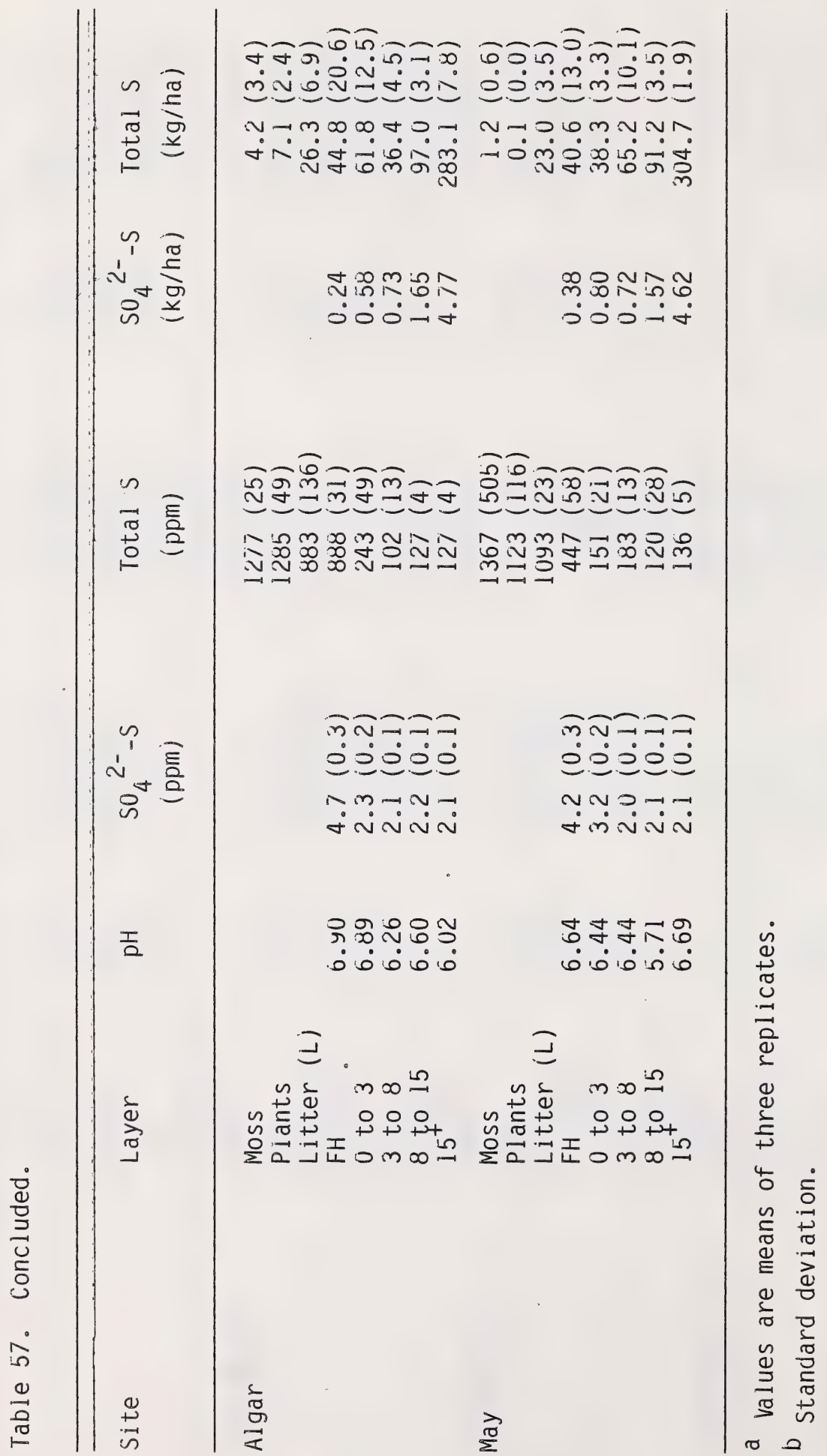


8.9 PRELIMINARY RESULTS OF THE MOVEMENT OF APPLIED SULPHATE SULPHUR IN FOREST SOILS EXPERIMENT 
132

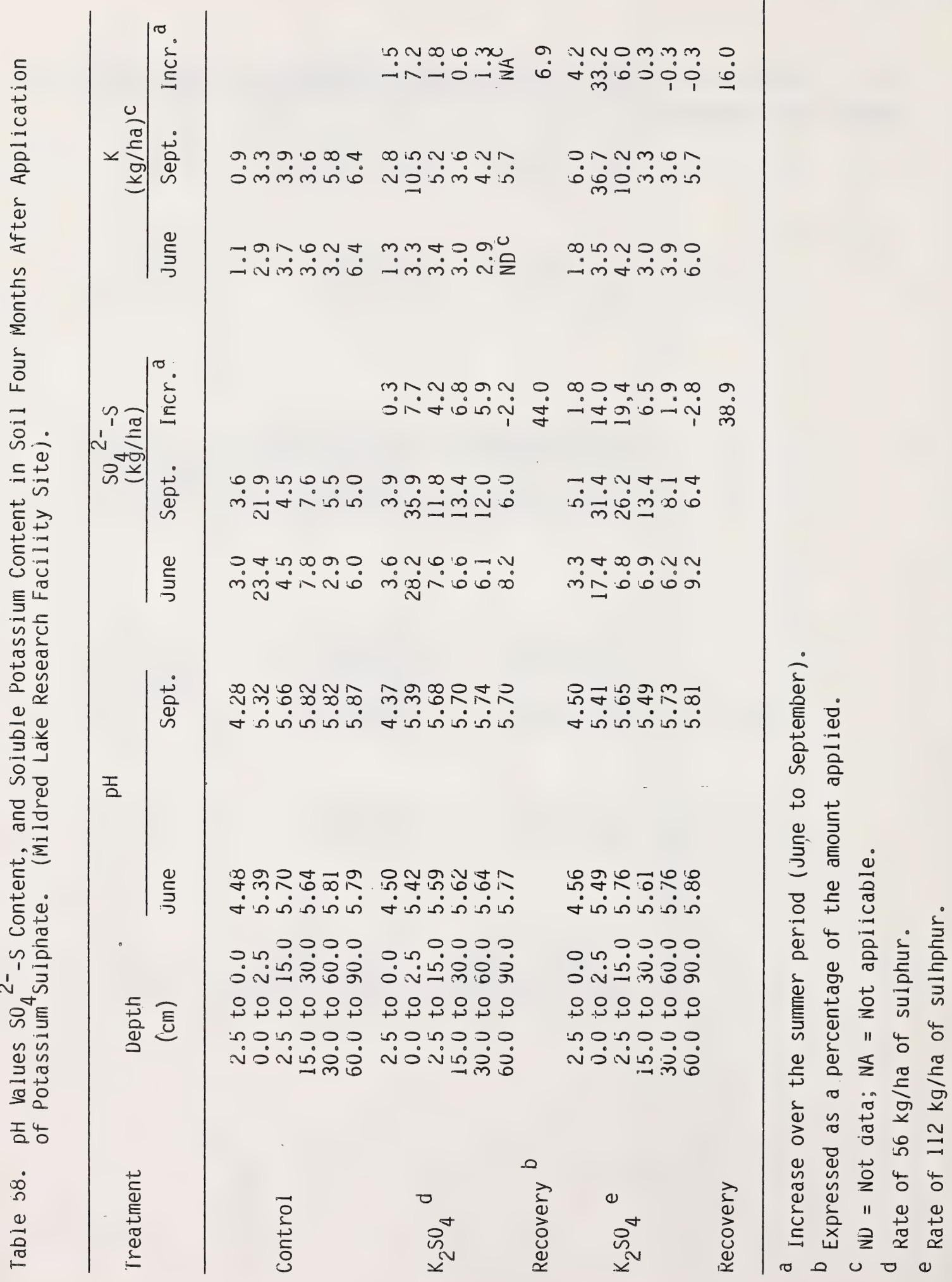




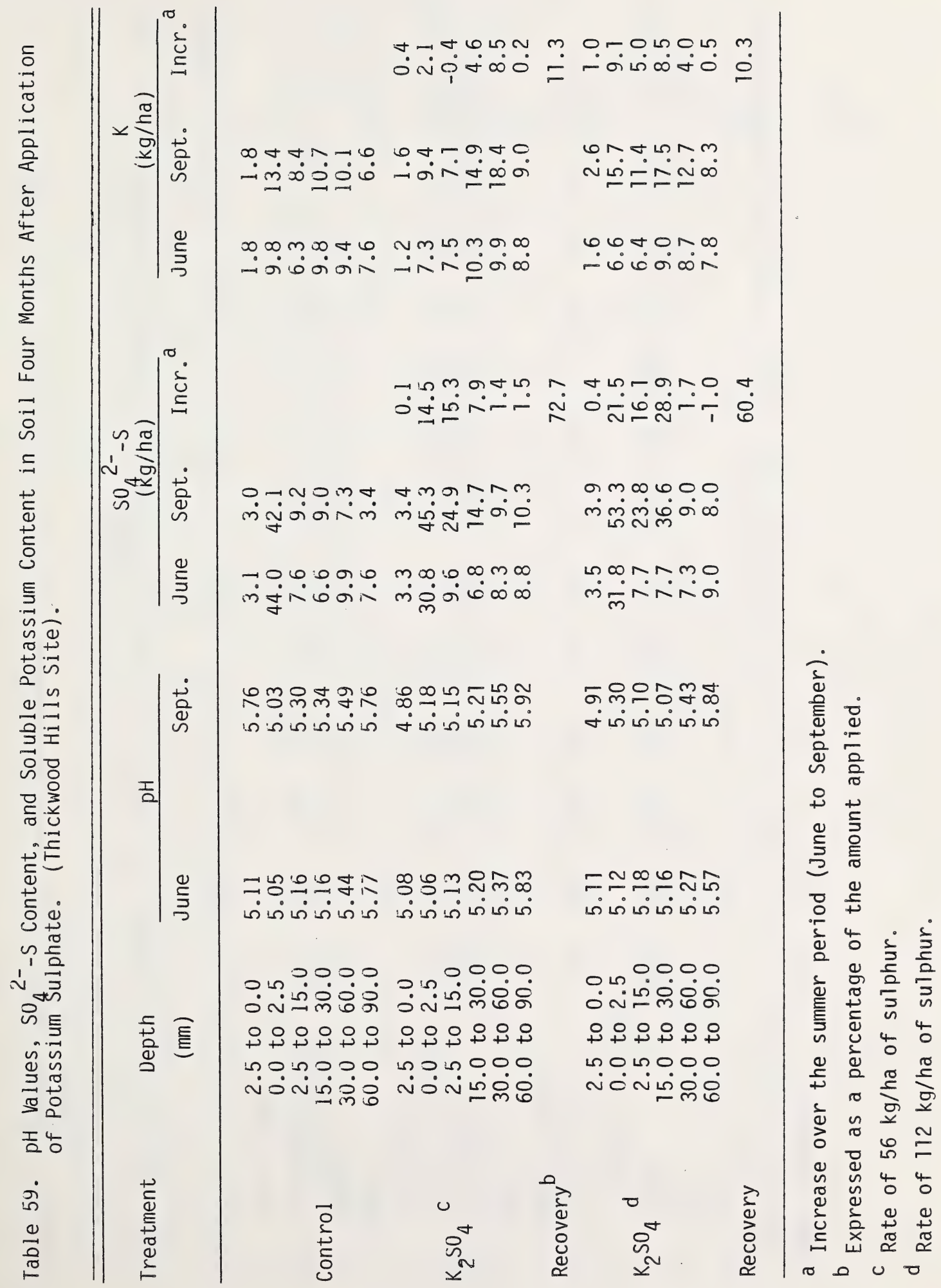


8.10 ANALYSIS OF LYSIMETER LEACHATES. 


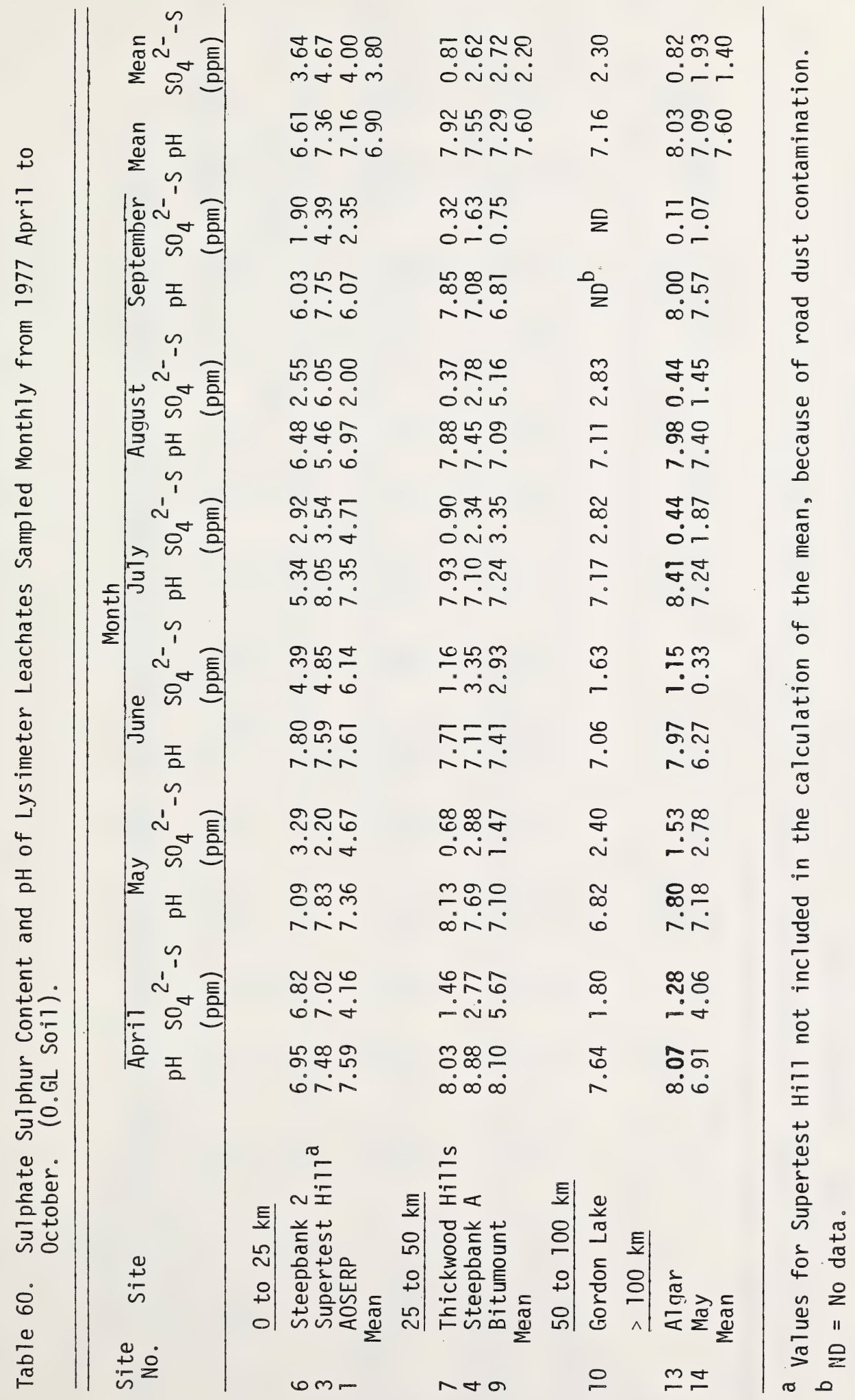




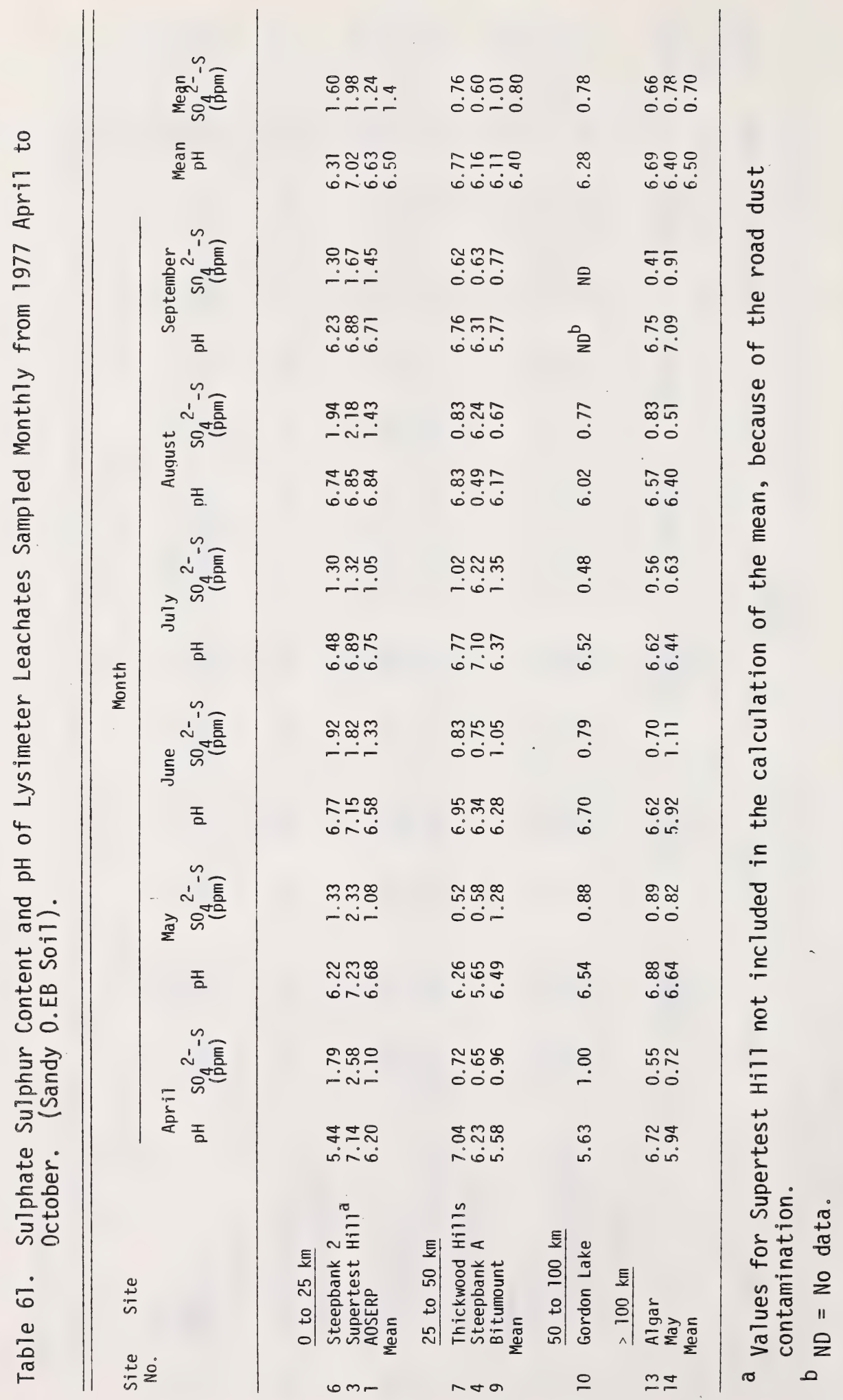




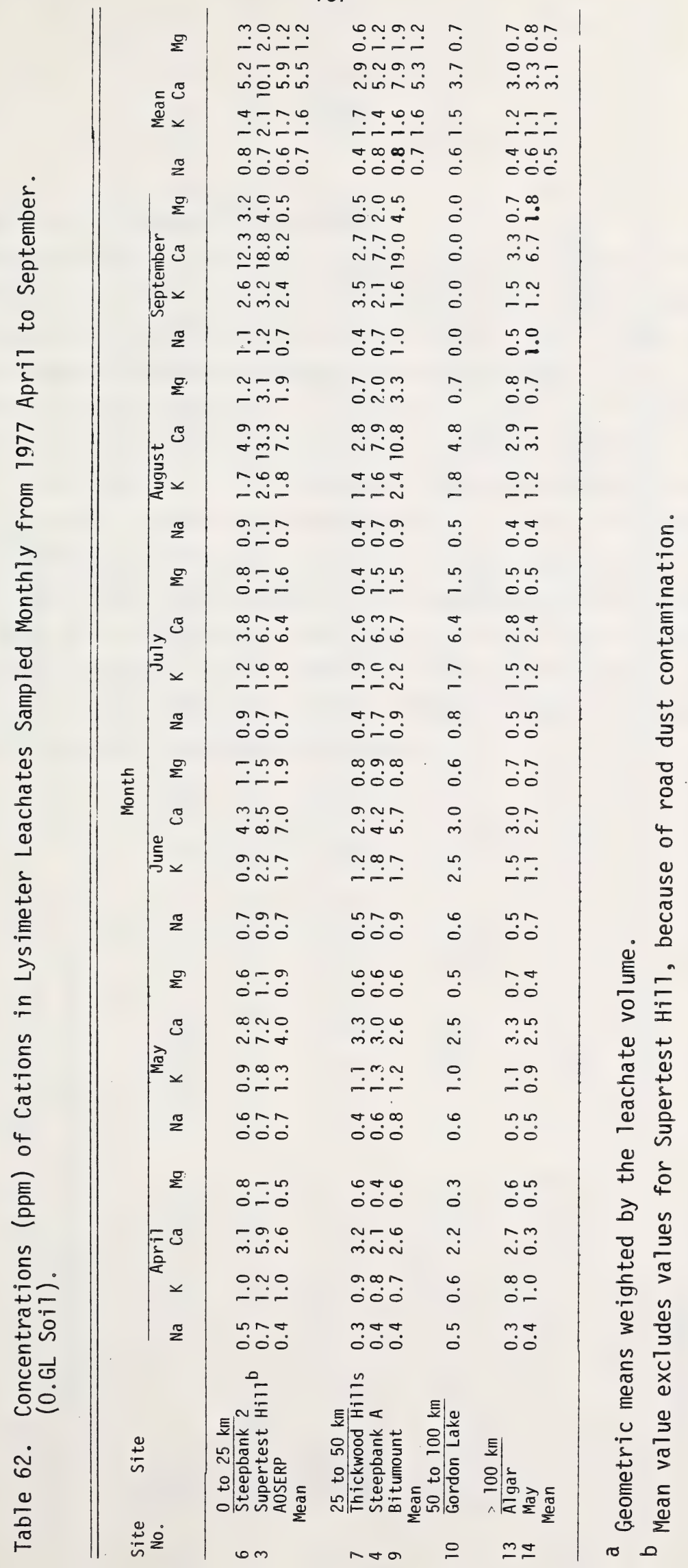




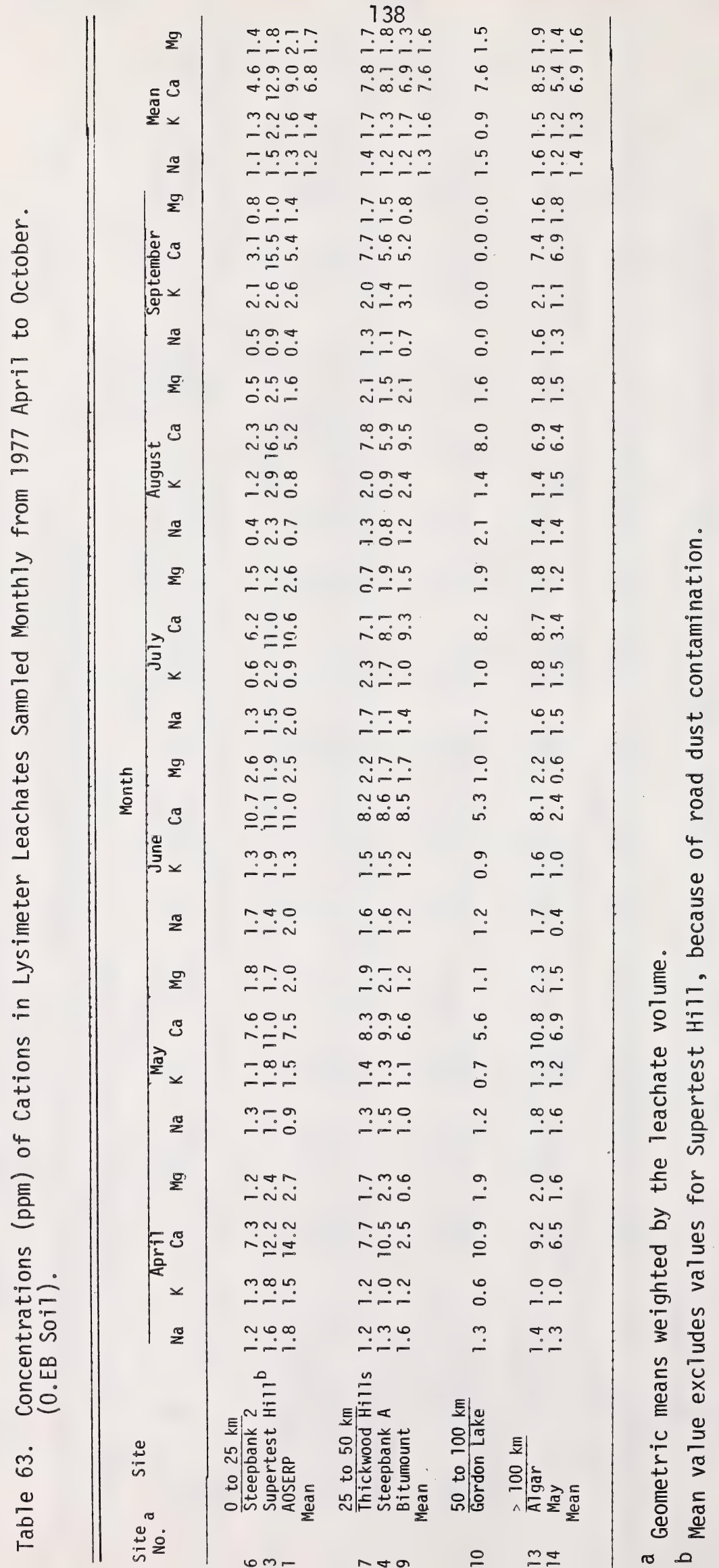




\subsection{ANALYSIS OF PERMANENT PLOT SOILS}

At the 15 sites, located at distances of 4 to $173 \mathrm{~km}$ from the emitter (Table 1, Figure 1), which were used for obtaining rain samples, and to expose soils in containers, permanent plots were set out in 1976. These replicated small plots (Figure 5) were soil sampled in 1976 and 1978.

The values were compared for 1976 and 1978 for soil content of scluble sulphate-S (Table 64), soil content of total S (Table 65), and soil pH (Table 66). During two years, one would not expect much change in natural soils, but there was a trend to an increase in soil pH in the organic layers from 1976 to 1978 and an increase in total S content in the mineral layers. In addition, there was little change in the soluble sulphate-s content in the soils, and this is to be expected considering the mobility of sulphate. However, these differences between 1976 and 1978 are best not over-emphasized because two years is a short span of time. These results will become more useful as soil sampling is made in the future. 


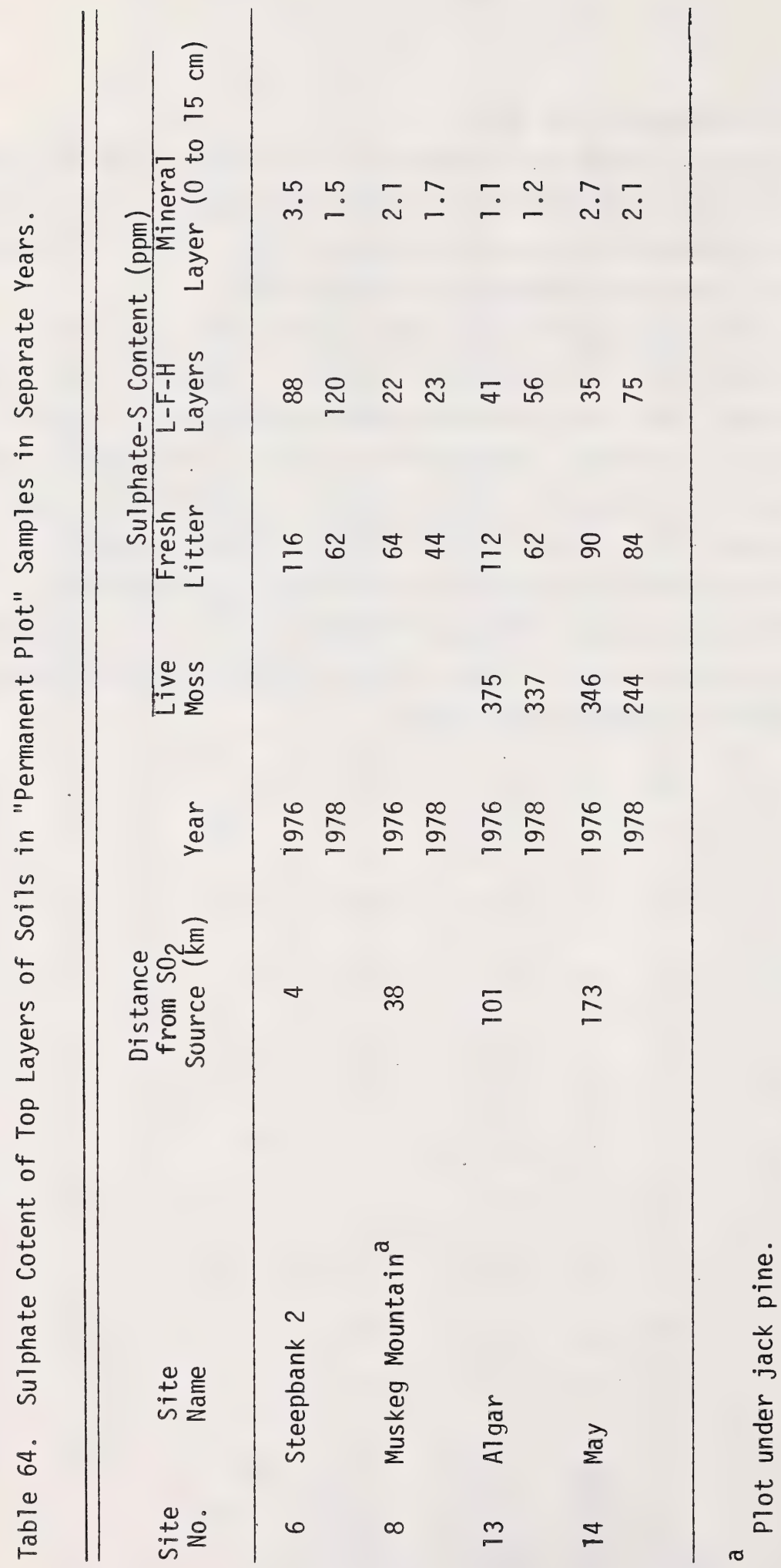




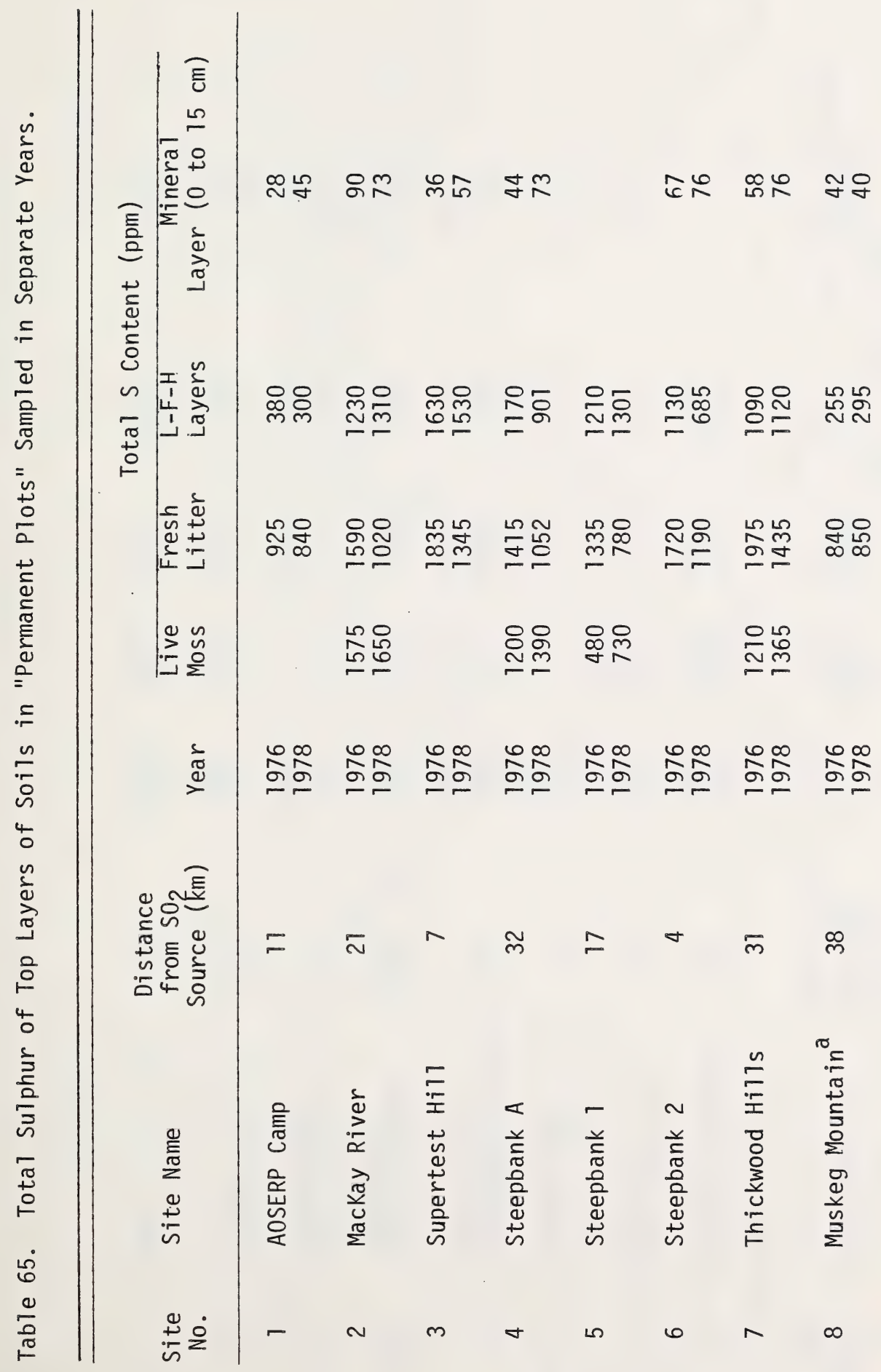




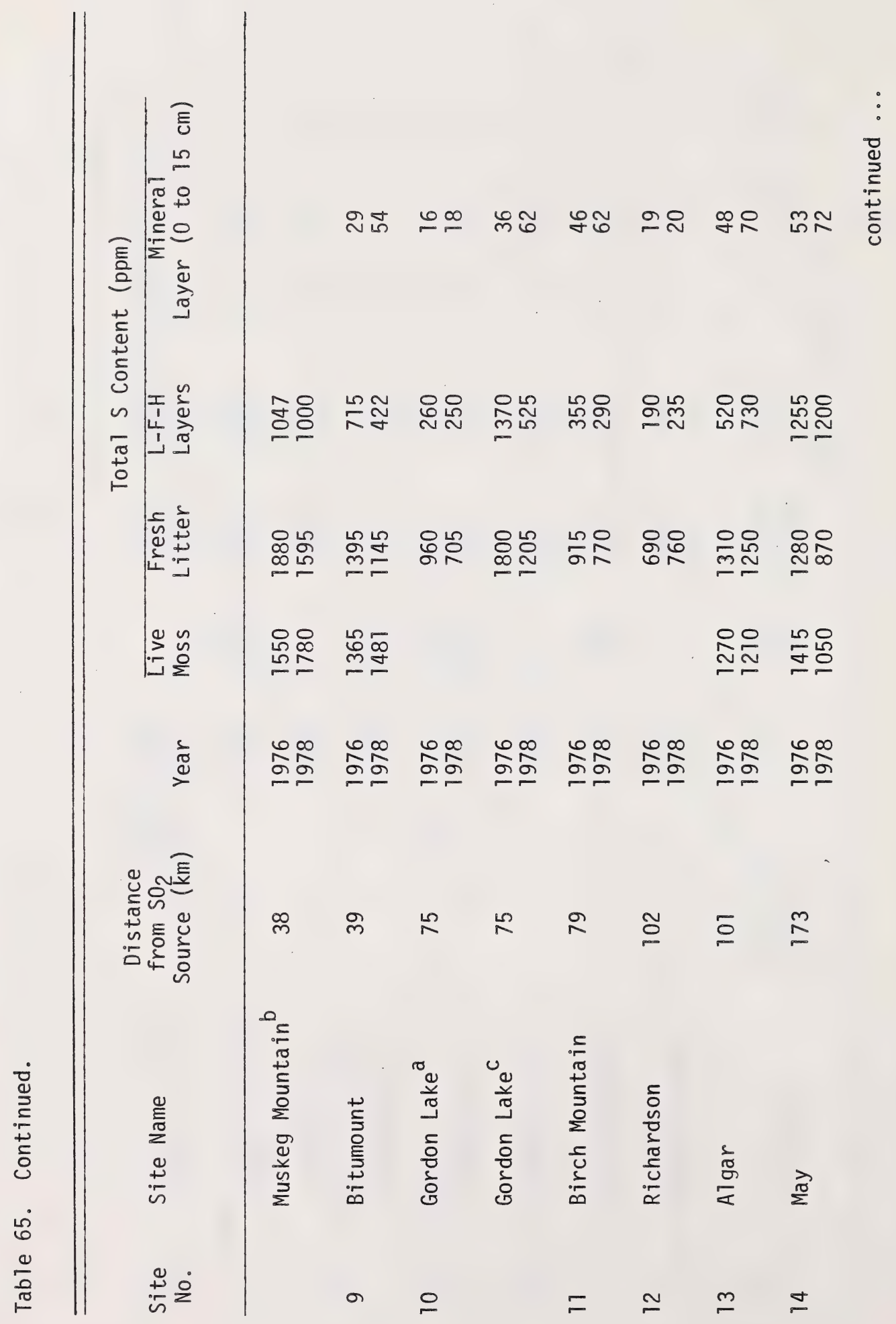




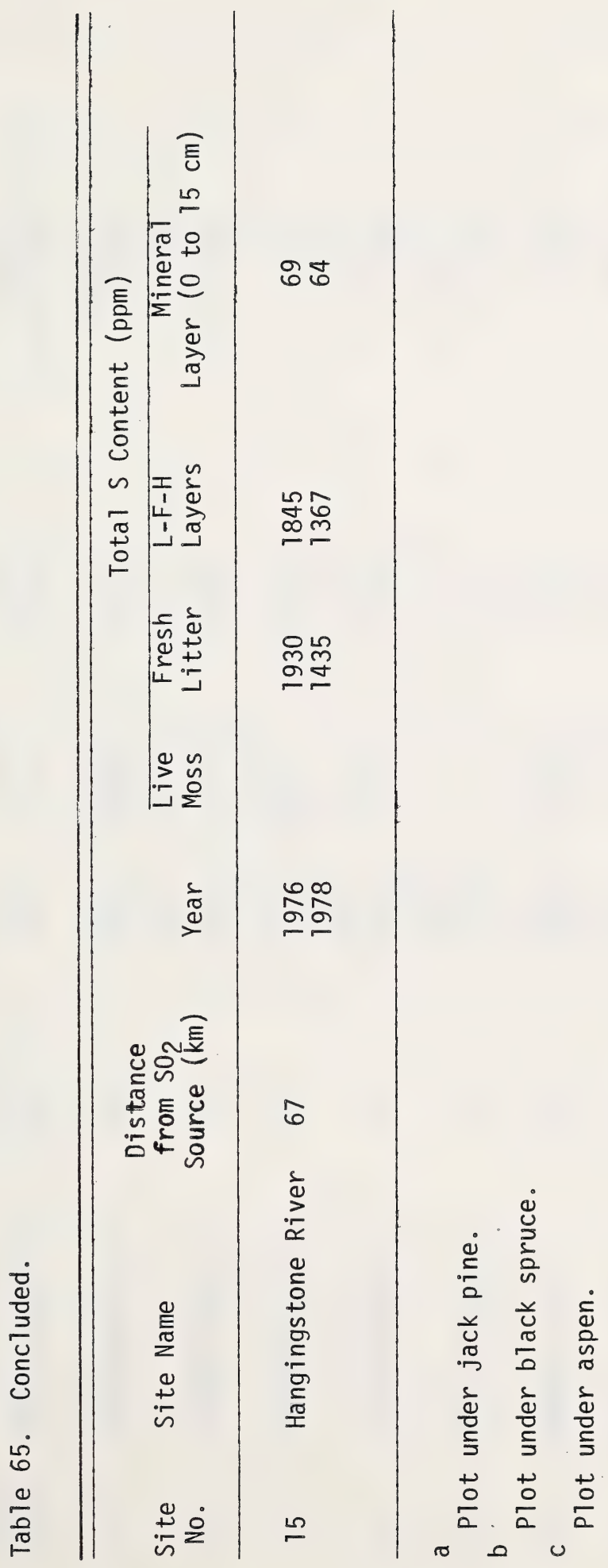




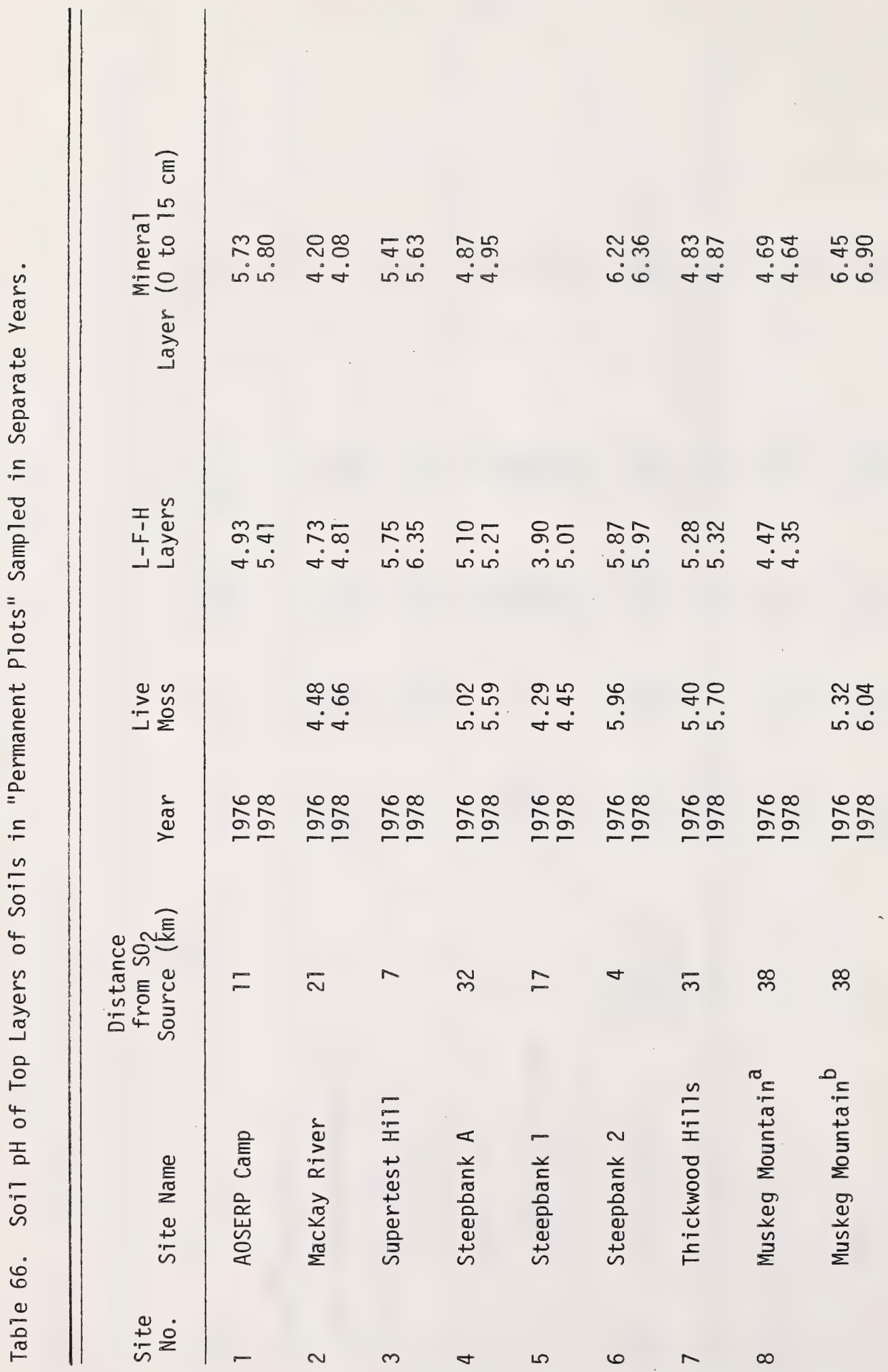




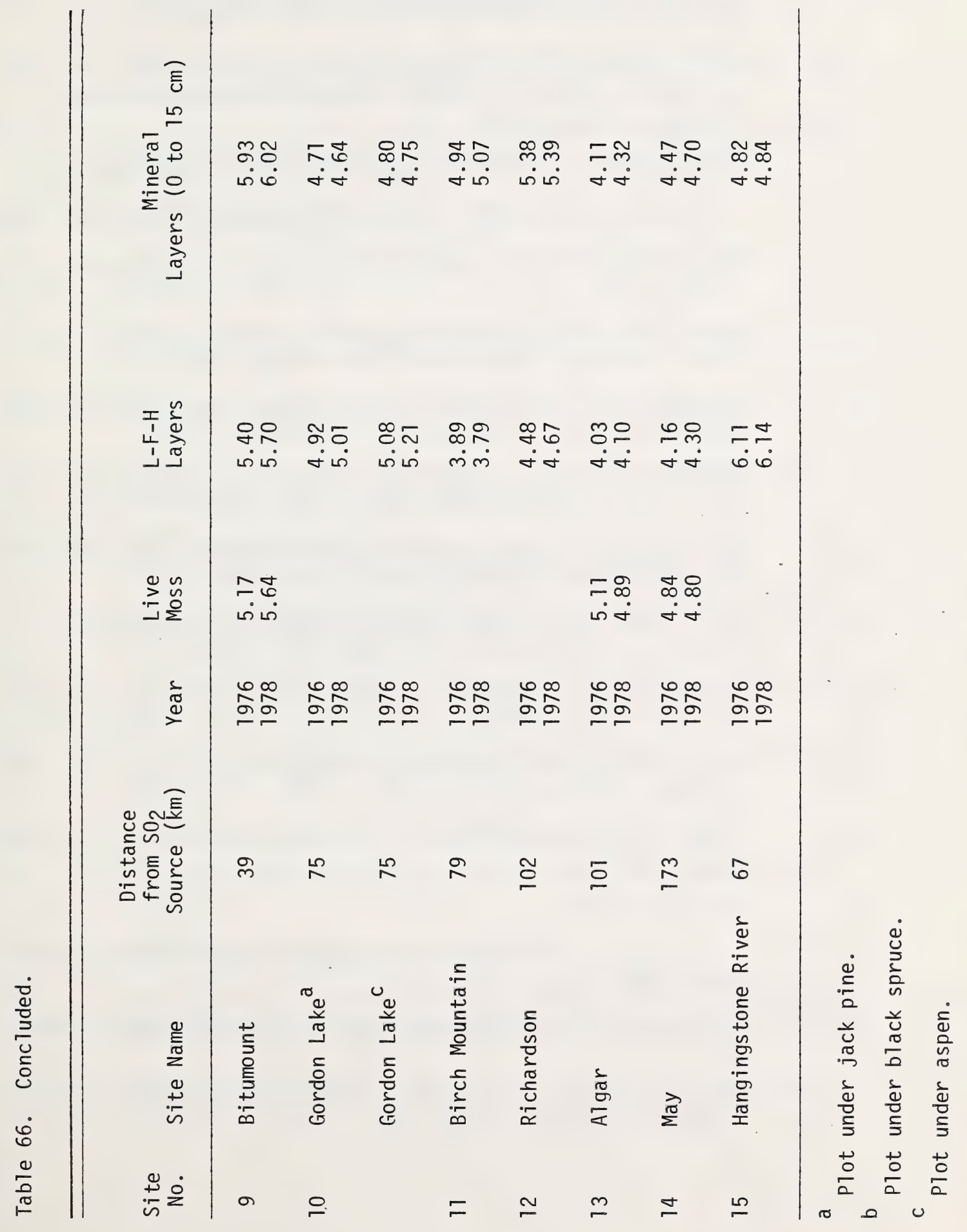


9. LIST OF AOSERP RESEARCH REPORTS

1. AOSERP first annual report, 1975.

2. Walleye and goldeye fisheries investigations in the PeaceAthabasca Delta--1975.

3. Structure of a traditional baseline data system. 1976.

4. A preliminary vegetation survey of the AOSERP study area. 1976.

5. The evaluation of wastewaters from an oil sand extraction plant. 1976.

6. Housing for the north--the stackwall system; construction report--Mildred Lake tank and pump house. 1976.

7. A synopsis of the physical and biological limnology and fishery programs within the Alberta oil sands area. 1977.

8. The impact of saline waters upon freshwater biota (a literature review and bibliography). 1977.

9. A preliminary investigation into the magnitude of fog occurrence and associated problems in the oil sands area. 1977.

10. Development of a research design related to archaeological studies in the Athabasca oil sands area. 1977.

11. Life cycles of some common aquatic insects of the Athabasca River, Alberta. 1977.

12. Very high solution meteorological satellite study of oil sands weather: "a feasibility study". 1977.

13. Plume dispersion measurements from an oil sands extraction plant, March 1976.

14. None published.

15. A climatology of low-level air trajectories in the Alberta oil sands area. 1977.

16. The feasibility of a weather radar near Fort McMurray, Alberta. 1977.

17. A survey of baseline levels of contaminants in aquatic biota of the AOSERP study area. 1977. 
18. Interim compilation of stream gauging data to December 1976 for AOSERP. 1977.

19. Calculations of annual averaged sulphur dioxide concentrations at ground level in the AOSERP study area. 1977.

20. Characterization of organic constituents in waters and wastewaters of the Athabasca oil sands mining area. 1978.

21. AOSERP second annual report, 1976-77.

22. AOSERP interim report covering the period April 1975 to November 1978.

23. Acute lethality of mine depressurization water to trout-perch and rainbow trout: Volume 1. 1979.

24. Air system winter field study in the AOSERP study area, February 1977.

25. Review of pollutant transformation process relevant to the Alberta oil sands area. 1977.

26. Interim report on an intensive study of the fish fauna of the Muskeg River watershed of northeastern Alberta. 1977.

27. Meteorology and air quality winter field study in the AOSERP study area, March 1976.

28. Interim report on a soils inventory in the Athabasca oil sands area. 1978.

29. An inventory system for atmospheric emissions in the AOSERP study area. 1978.

30. Ambient air quality in the AOSERP study area. 1977.

31. Ecological habitat mapping of the AOSERP study area: Phase 1. 1978.

32. AOSERP third annual report, 1977-78.

33. Relationships between habitats, forages, and carrying capacity of moose range in northern Alberta. Part 1: moose preferences for habitat strata and forages. 1978.

34. Heavy metals in bottom sediments of the mainstem Athabasca River upstream of Fort McNurray: Volume 1. 1978. 
35. The effects of sedimentation on the aquatic biota. 1978.

36. Fall fisheries investigations in the Athabasca and Clearwater rivers upstream of Fort McMurray: Volume 1. 1978.

37. Community studies: Fort McMurray, Anzac, and Fort Mackay. 1978.

38. Techniques for the control of small mammal damage to plants: a review. 1979.

39. The climatology of the AOSERP study area. 1979.

40. Mixing characteristics of the Athabasca River below Fort McMurray --winter conditions. 1979.

41. Acute and chronic toxicity of vanadium to fish. 1978.

42. Analysis of fur production records for registered traplines in the AOSERP study area, 1970-1975.

43. A socio-economic evaluation of the recreational use of fish and wildlife resources in Alberta, with particular reference to the AOSERP study area. Vol. 1: summary and conclusions. 1979.

44. Interim report on symptomology and threshold levels of air pollutant injury to vegetation, 1975 to 1978.

45. Interim report on physiology and mechanisms of air-borne pollutant injury to vegetation, 1975 to 1978.

46. Interim report on ecological benchmarking and biomonitoring for detection of air-borne pollutant effects on vegetation and soils, 1975 to 1978.

47. A visibility bias model for aerial surveys of moose in the AOSERP study area. 1979.

48. Interim report on a hydrogeological investigation of the Muskeg River basin, Alberta. 1979.

49. The ecology of macrobenthic invertebrate communities in Harley Creek, northeastern Alberta.

50. Literature review on pollution deposition processes. 1979.

51. Interimi compilation of 1976 suspended sediment data for the AOSERP study area. 1979. 
52. Plume dispersion measurements from an oil sands extraction plant, June 1977.

53. Baseline states of organic constituents in the Athabasca River system upstream of Fort McMurray. 1979.

54. A preliminary study of chemical and microbial characteristics of the Athabasca River in the Athabasca oil sands area of northeastern Alberta. 1979.

55. Microbial populations in the Athabasca River. 1979.

56. The acute toxicity of saline groundwater and of vanadium to fish and aquatic invertebrates. 1979.

57. Ecological habitat mapping of the AOSERP study area (supplement): Phase 1. 1979.

58. Interim report on ecological studies on the lower trophic levels of Muskeg rivers within the AOSERP study area. 1979.

59. Semi-aquatic mammals: annotated bibliography. 1979.

60. Synthesis of surface water hydrology. 1979.

61. An intensive study of the fish fauna of the Steepbank river watershed of northeastern Alberta. 1979.

62. Amphibians and reptiles in the AOSERP study area. 1979.

63. Analysis of AOSERP plume sigma data. 1979.

64. A review and assessment of the baseline data relevant to the impacts of oil sands developments on large mammals in the AOSERP study area. 1979.

65. A review and assessment of the baseline data relevant to the impacts of oil sands development on black bear in the AOSERP study area. 1979.

66. An assessment of the models LIRAQ and ADPIC for application to the Alberta oil sands area. 1979.

67. Aquatic biological investigations of the Muskeg River watershed. 1979.

68. Air system summer field study in the AOSERP study area, June 1977. 
69. Native employment patterns in Alberta's Athabasca oil sands region. 1979.

70. An interim report on the insectivorous animals in the AOSERP study area.

71. Lake acidification potential in the AOSERP study area. 1979.

72. The ecology of five major species of small mammals in the AOSERP study area: a review. 1979.

73. Distribution, abundance, and habitat associations of beavers, muskrats, mink, and river otters in the AOSERP study area, northeastern Alberta. 1979.

74. Air quality modelling and user needs. 1979.

75. Interim report on a comparative study of benthic algal primary productivity in the AOSERP study area. 1979.

76. An intensive study of the fish fauna of the Muskeg River watershed of northeastern Alberta. 1979.

77. Overview of local economic development in the Athabasca oil sands region since 1976.1979.

78. Habitat relationships and management of terrestrial birds in northeastern Alberta. 1979.

79. The multiple toxicity of vanadium, nickel, and phenol to fish. 1979.

80. History of the Athabasca oil sands region, 1890 to 1960's. Volume 1: socio-economic developments. Volume 11: oral history. 1980.

81. Species distribution and habitat relationships of waterfowl in northeastern Alberta. 1979.

82. Breeding distribution and behaviour of the White Pelican in the Athabasca oil sands area. 1979.

83. The distribution, foraging behaviour and allied activities of the White Pelican in the Athabasca oil sands area. 1979.

84. Investigations of the spring spawning fish populations in the Athabasca and Clearwater rivers upstream from Fort McMurray: Volume 1. 1979. 
85. An intensive surface water quality study of the Muskeg River watershed. Volume 1: water chemistry. 1979.

86. An observational study of fog in the AOSERP study area. 1979.

87. Hydrogeological investigation of Muskeg River basin, Alberta. 1980.

88. Ecological studies of the aquatic invertebrates of the AOSERP study area of northeastern Alberta. 1980.

89. Fishery resources of the Athabasca River downstream of Fort McMurray, Alberta: Volume 1. 1989.

90. A wintertime investigation of the deposition of pollutants around an isolated power plant in northern Alberta. 1980.

91. Characterization of stored peat in the Alberta oil sands area. 1980.

92. Fisheries and habitat investigations of tributary streams in the southern portion of the AOSERP study area. Volume 1: summary and conclusions. 1980.

93. Fisheries and aquatic habitat investigations in the Mackay River watershed of northeastern Alberta. 1980.

94. A fisheries and water quality survey of ten lakes in the Richardson Tower area, northeastern Alberta. Volume 1: methodology, summary, and discussion. 1980.

95. Evaluation of the effects of convection on plume behaviour in AOSERP study area. 1980.

96. Service delivery in the Athabasca oil sands region since 1961 . 1980.

97. Differences in the composition of soils under open and canopy conditions at two sites close-in to the Great Canadian $0 i 1$ Sands operation, Fort McMurray, Alberta. 1980.

98. Baseline condition of jack pine biomonitoring plots in the Athabasca oil sands area: 1976-1977.

99. Synecology and autecology of boreal forest vegetation in the AOSERP study area. 1980.

100. Baseline inventory of aquatic macrophyte species distributions in the AOSERP study area: 1980. 
101. Woodland caribou populations dynamics in northeastern Alberta. 1980.

102. Wolf population dynamics and prey relationships in northeastern Alberta. 1980.

103. Analysis of the leisure delivery system 1972-1979, with projections for future servicing requirements.

104. Review of requirements for air quality simulation models. 1980:

105. Approaches to the design of a biomonitoring program using arthropods as bioindicators for the AOSERP study area. 1980.

106. Meteorological factors affecting ambient $\mathrm{SO}_{2}$ concentrations near an oil sands extraction plant. 1980.

107. Small mammal populations of northeastern Alberta. Volume 1: populations in natural habitats. 1980.

108. Small mammal populations of northeastern Alberta. Volume 11: populations in reclamation areas. 1980.

109. Symptomology and threshold levels of air pollutant injury to vegetation, 1979-1980.

110. Physiology and mechanisms of airborne pollutant injury to vegetation, 1979-1980.

111. Ecological benchmarking and biomonitoring for detection of airborne pollutant effects on vegetation and soils. 1980.

112. A study of human adjustment in Fort McMurray. Volume 1: field study and results. 1980.

113. A laboratory study of long-term effects of mine depressurization groundwater on fish and invertebrates. 1980.

114. Aquatic biophysical inventory of major tributaries in the AOSERP study area. Volume 1: summary report. 1980.

115. Report on an ecological survey of terrestrial insect communities in the AOSERP study area. 1980.

116. An assessment of benthic secondary production in the Muskeg River of northeastern Alberta. 1980.

117. Development of a chemically reactive plume model for application in the AOSERP study area. 1981. 
118. Alberta 0il Sands Environmental Research Program, 1975-1980. A summary report. 1981 .

119. Airshed management system for the Alberta oil sands. Volume 1: A Gaussian frequency distribution model. 1981.

120. Airshed management system for the Alberta oil sands. Volume 11: meteorological data.

121. The metabolism of selected organic compounds by microorganisms in the Athabasca River.

122. Soil inventory of the AOSERP study area.

123. Circulation of water and sediment in the Athabasca delta area. 1981.

124. Airshed management system for the Alberta oil sands. Volume 111: validation and sensitivity studies.

125. The 1981 snowpack survey in the AOSERP study area. 1981.

126. Modelling the topographic effects on winds in the Alberta oil sands a rea. 1982 .

127. Alberta 0 il Sands Environmental Research Program annual report for the fiscal year $1981 / 82$.

128. A comparative study of benthic algal primary productivity in the AOSERP study area. 1982.

129. Athabasca 0 il Sands precipitation chemistry studies: 1976-79 and 1981. 1982.

130. Climatological analysis of recent data from the Athabasca 0il Sands area. 1984. 


